\title{
Espaços Arquitetônicos de Alta Tecnologia: Os Edifícios Inteligentes
}

Raïssa Pereira Alves de Azevêdo Neves

Dissertação apresentada à Escola de Engenharia de São Carlos da Universidade de São Paulo, como parte dos requisitos necessários à obtenção do título de Mestre em Arquitetura e Urbanismo

Orientador:

Prof. Dr. Azael Rangel Camargo 
Aos meus pais Juca, Helena e Rosamaria e a meu esposo Rodrigo 


\section{Agradecimentos}

Ao Prof. Dr. Azael Rangel Camargo, pela dedicação, interesse e compreensão, amizade e paciência...

Ao Prof. Dr. Ricardo Martuccie ao Prof. Dr. José Mário Nogueira de Carvalho Júnior, membros da banca, pelas importantes contribuiçoes que ajudaram na conclusão desta dissertação.

Ao Prof. Dr. Admir Basso pela colaboração no empréstimo de equipamento.

A minha familia, sempre presente em todos os momentos de minha vida.

Aos amigos dos Departamentos de Arquitetura e Urbanismo, Estruturas e membros do E-Urb, pela amizade.

Aos funcionários do Departamento de Arquitetura e Urbanismo, em especial a Marcelo Celestini, Paulo Ceneviva, Oswaldo de Andrade, Eduardo Zanardi, Sérgio Celestini, Fátima Mininel, João

Tessarin Lucinda Torres, pela atenção e presteza

Aos Eng Manoel Marques e Amadeu Fábio Júnior, funcionários da Tishman Speyer Método, por permitirem a visita ao Centro Empresarial Nações Unidas e por fornecerem informações essenciais para esta pesquisa.

À CAPES, pelo apoio financeiro. 


\section{Sumário}

1 CONTEXTUALIZAÇÃO DA PESQUISA.

1.1 INTRODUÇÃO

1.2 OBJETVOS

1.3 METODOLOGIA.

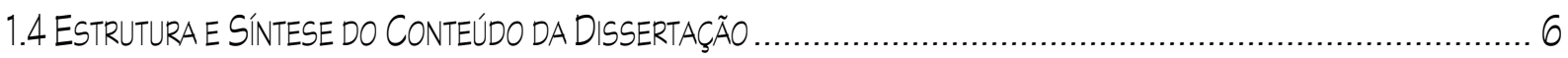

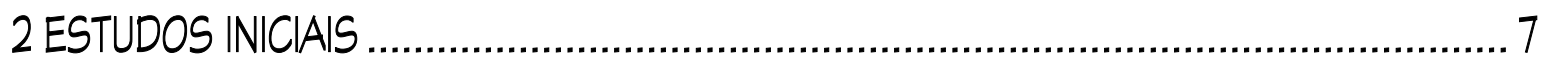

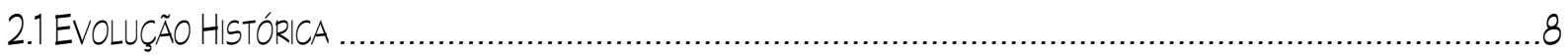

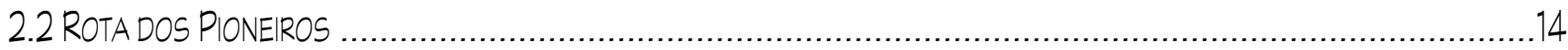

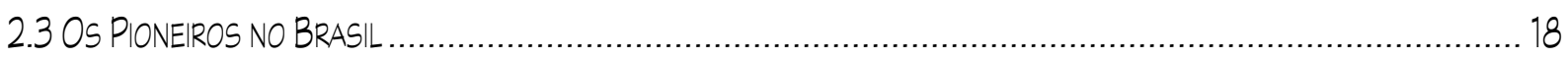

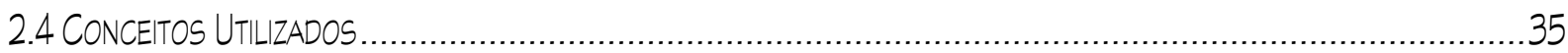

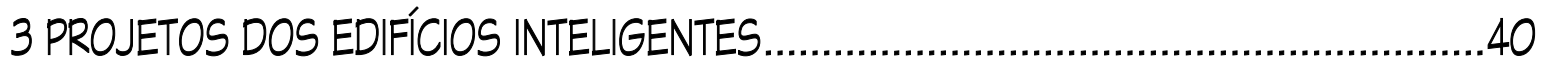

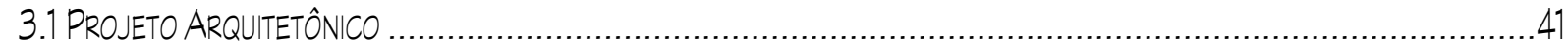

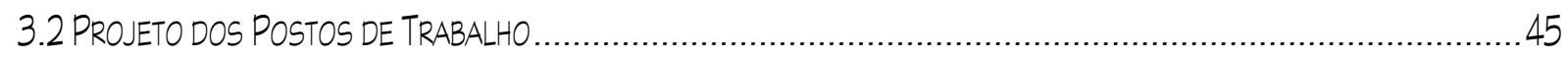

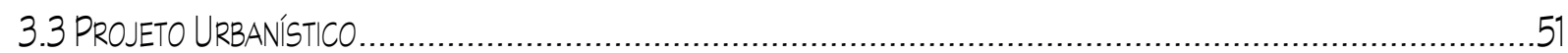

4 ASPECTOS PROJETUAIS E CONSTRUTIVOS PARA ABRIGAR A ALTA TECNOLOGIA -

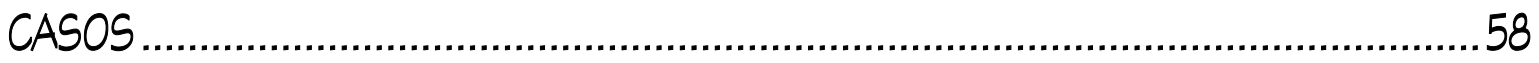

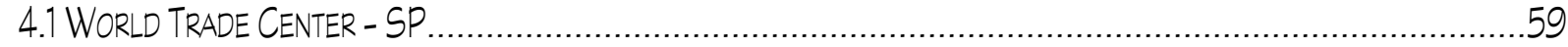

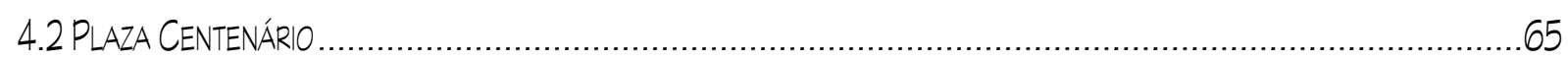

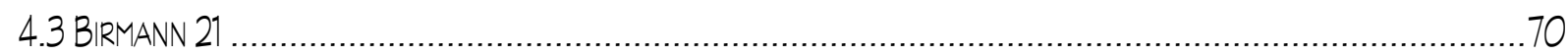

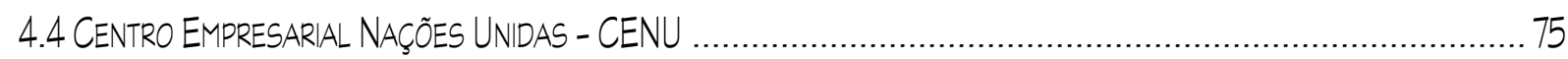

5 ORGANIZAÇÃO DOS SISTEMAS E SERVIÇOS E A INTEGRAÇÃO ENTRE ELES ...........88

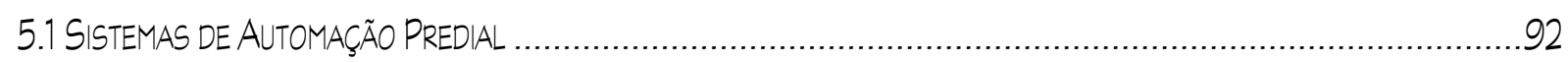

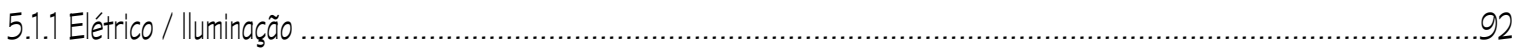

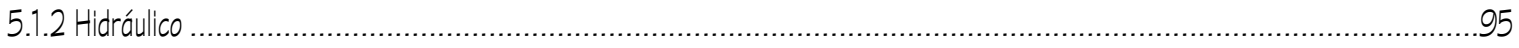

5.13 Deteç̧̃̃o e Alarme de Incêndio ......................................................................................................96

5.14 Condicionamento Ambiental ......................................................................................................98

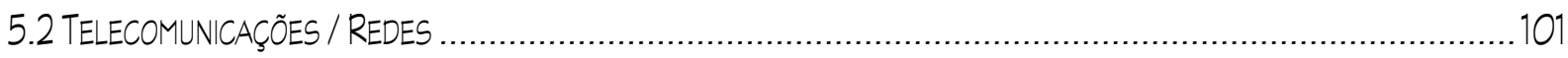

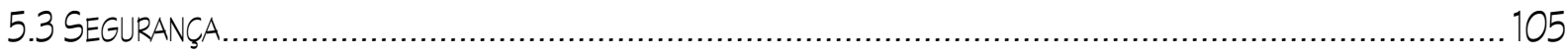

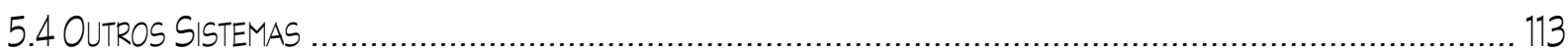

5.4.1 Transporte Vertical ........................................................................................................... 113

5.4.2 Conforto Acústico / Sonorização de Ambientes..............................................................................................118

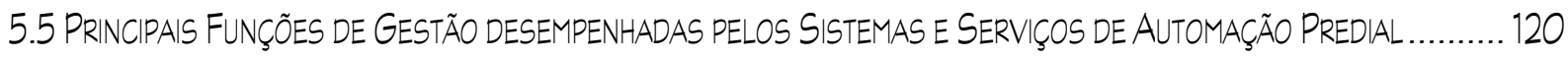

5.5 .1 Gestão dos Sistemas e Servigos................................................................................................... 120

5.5 .2 Gerenciamento da Energia ..............................................................................................122

5.5.3 Gestão da Seguranga dos Sistemas................................................................................................123

6 A GESTÃO EMPRESARIAL E OS INVESTIMENTOS NOS EDIFÍCIOS INTELIGENTES.... 124

6.1 GESTÃO DA PRODUÇÃO

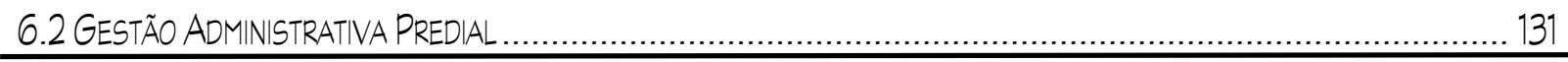


6.3 INVESTIMENTOS EM EDIFÍCIOS INTELIGENTES

7 CONCLUSÃO

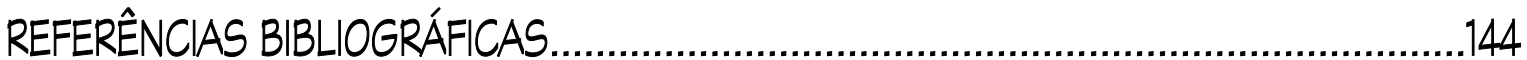




\section{Lista de Figuras}

Fig. 1 As maiores torres do planeta...... 10

Fig. 2 Edifício Larkin - Búfalo 14

Fig. 3 Edifício Empire State Building - NY 15

Fig. 4 Trabalhadores do ESB - almoço. 15

Fig. 5 World Trade Center - NY 16

Fig. 6 Detalhe da fachada das torres do WTC - NY 16

Fig. 7 Planta do complexo WTC - NY 16

Fig. 8 Edifício da ATÆT - NY .17

Fig. 9 Edifício da Lloyd's - Londres. .17

Fig. 10 Planta do edifício Fonte: .17

Fig. 11 Sede do Citibank - SP 18

Fig. 12 Corte lateral 18

Fig. 13 Planta do pavimento térreo. 18

Fig. 14 Detalhe dos volumes 18

Fig. 15 Detalhe das grelhas de concreto. .18

Fig. 16 Detalhe do acesso ao prédio. 18

Fig. 17 Detalhe do pé direito (interior do edifício). 18

Fig. 18 Edifício Centro Empresarial Itaú 19

Fig. 19 Planta do $1^{0}$ pav. (auditório). 19

Fig. 20 Auditório 19

Fig. 21 Postos de Consulta Informatizados 19

Fig. 22 Corte longitudinal. 19

Fig. 23 Edifício Alfacon Steel Tower - SP. 20

Fig. 24 World Trade Center - SP .21 
Fig. 25 WTC - SP Corte Transversal pela torre do Hotel.

Fig. 26 Plaza Centenário - SP

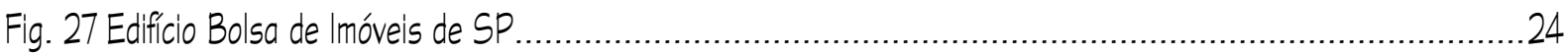

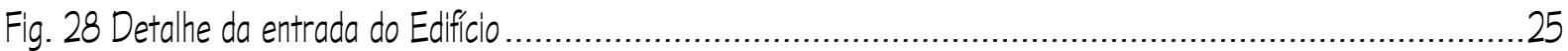

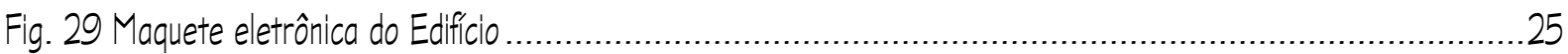

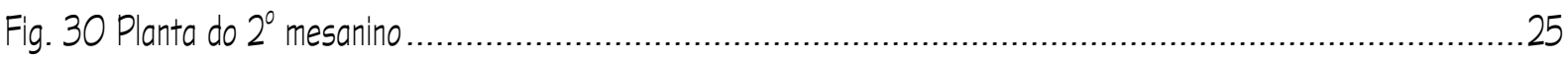

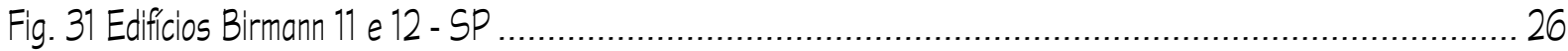

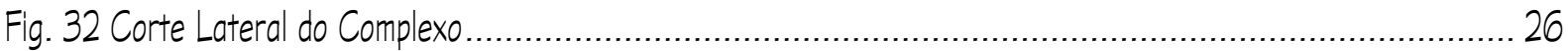

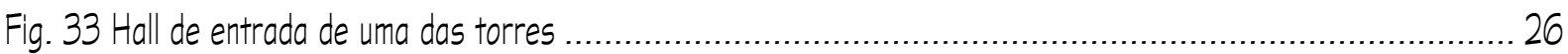

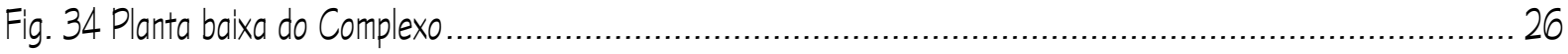

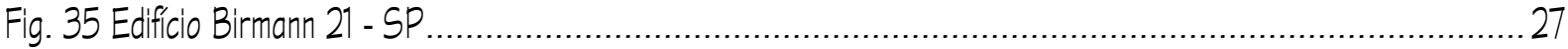

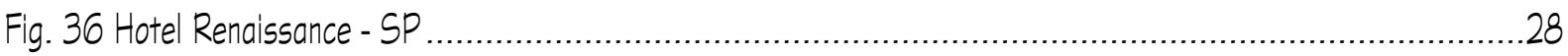

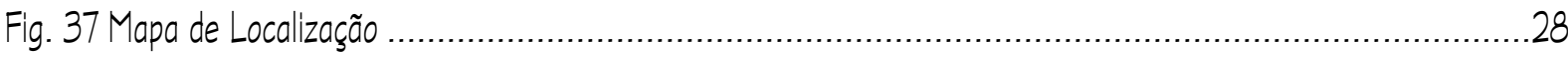

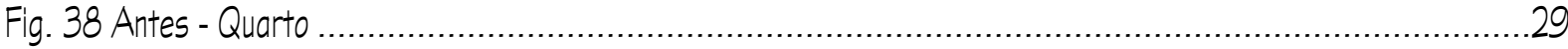

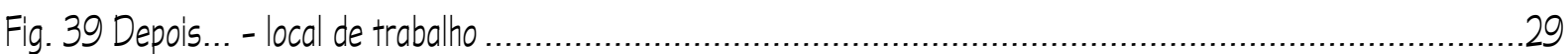

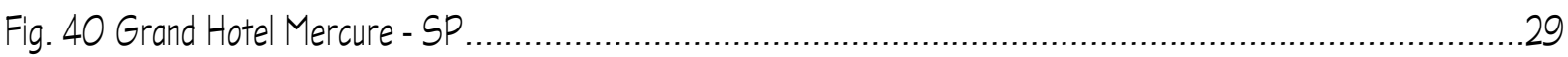

Fig. 41 Centro Empresarial Nações Unidas - SP maquete eletrônica ..................................................... 30

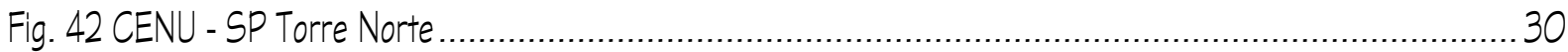

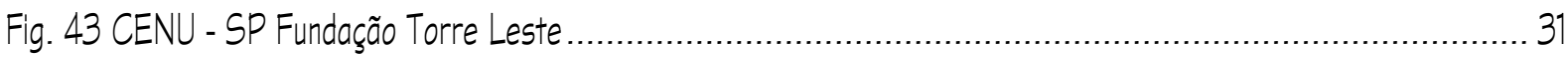

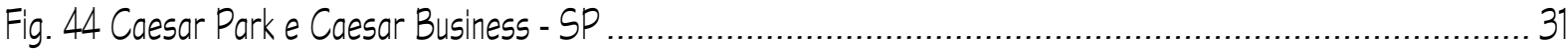

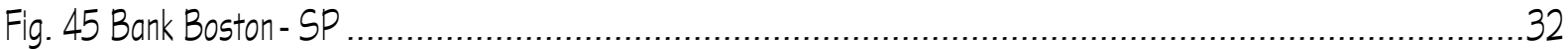

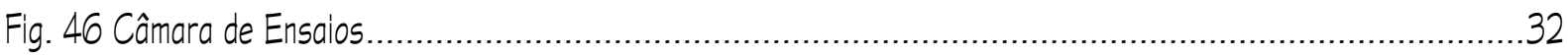

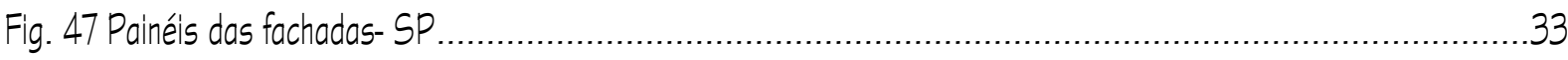

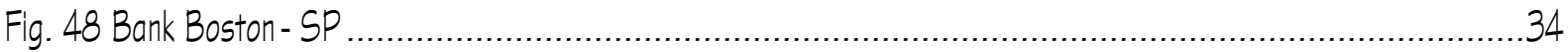

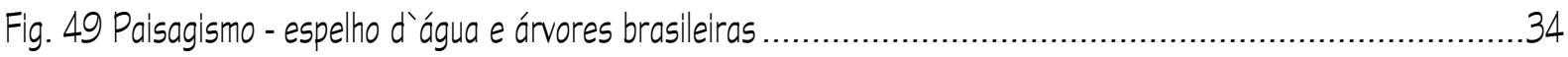


Fig. 50 Gráfico de convergência das tecnologias de Telemática, Telecomunicações e mídias

Fig. 51 Edifício com insuflamento de ar pelo piso 36

Fig. 52 Edifício com sistema de teleconferência 36

Fig. 53 Casa High Tech 36

Fig. 54 Cozinha inteligente 36

Fig. 55 Central de sucção 36

Fig. 56 Acesso a e-mails virtuais. 36

Fig. 57 Exemplo de Shaft. 39

Fig. 58 Exemplo de Piso elevado 39

Fig. 59 Exemplo de Gesso Acartonado. 39

Fig. 60 Exemplo de Fachadas Ventiladas

Fig. 61 Exemplo de Escritório Antigo

Fig. 62 Escritório moderno - tendência.

Fig. 63 Sistema K fabricado pela Giroflex 50

Fig. 64 Maquete eletrônica dos Edifícios da Marginal Pinheiros - SP.

Fig. 65 Destaque para o CENU, na marginal Pinheiros - SP .53

Fig. 66 Terrenos incorporáveis na Berrini 56

Fig. 67 Área externa do Hotel. 60

Fig. 68 Planta do pavimento tipo do hotel. 61

Fig. 69 Planta da Torre de Escritórios. 61

Fig. 70 Detalhe da treliça espacial metálica 62

Fig. 71 Grelhas da fachada da torre de escritórios. 63

Fig. 72 Shopping D\&D - WTC-SP 64

Fig. 73 Interior do Shopping 1 64

Fig. 74 Interior do Shopping 2 64 
Fig. 75 Torre do Hotel- WTC-SP

Fig. 76 Área externa entre o complexo.

Fig. 77 Torre do Hotel- WTC-SP.

Fig. 78 Vista da torre. 66

Fig. 79 Detalhe da torre - revestimento de alumínio

Fig. 80 Planta do pavimento tipo

Fig. 81 Sala de controles.

Fig. 82 Sala de controles

Fig. 83 Planta do térreo

Fig. 84 Planta do Mezanino 70

Fig. 85 Implantação .71

Fig. 86 Detalhe da fachada 72

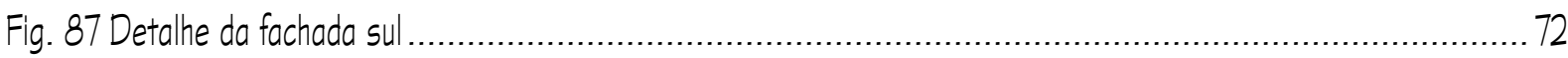

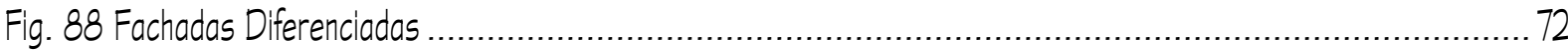

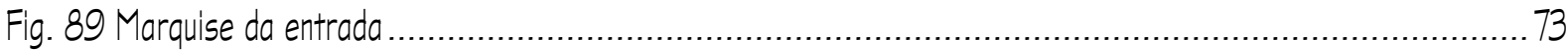

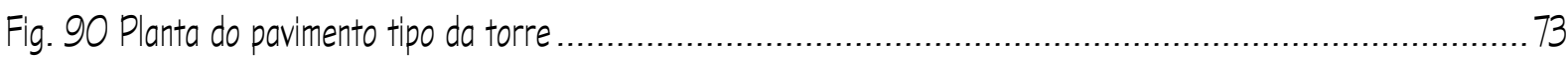

Fig. 91 Esquema da fachada ventilada, piso elevado e forro removível ...................................................... 75

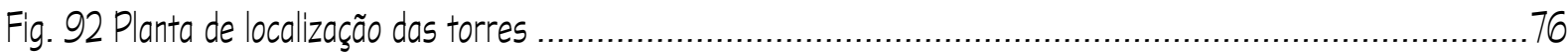

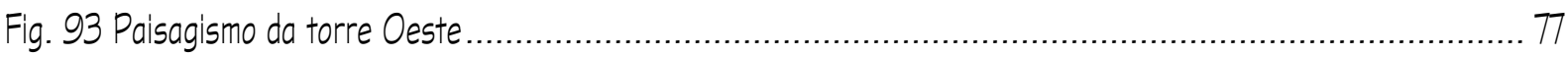

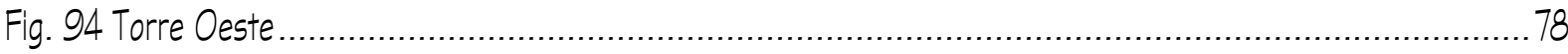

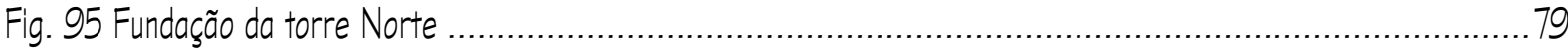

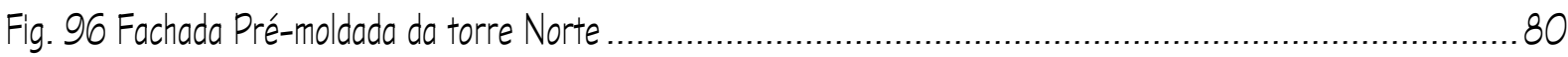

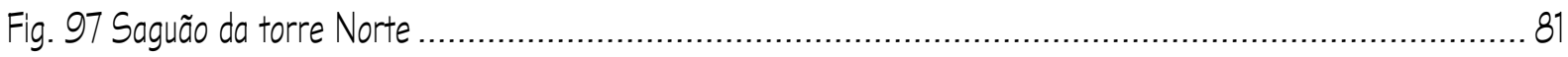

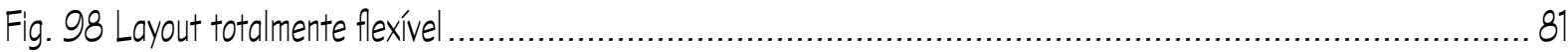

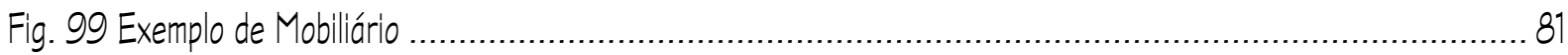


Fig. 100 Detalhe do encaixe da esquadria

Fig. 101 Detalhe do vidro duplo

Fig. 102 Detalhe do gesso acartonado.

Fig. 103 Detalhe do piso elevado.

Fig. 104 Torre Leste

Fig. 105 Detalhe de interligação dos banheiros pré-fabricados com as prumadas

Fig. 106 Instalações de um apartamento padrão antes do fechamento do Dry wall...

Fig. 107 Maquete Eletrônica do Complexo CENU e prédios vizinhos

Fig. 108 Sistemas e Serviços oferecidos nos Edifícios Inteligentes.

Fig. 109 Consumo por uso final em Edifícios Comerciais.

Fig. 110 Gerador da Compaq - CENU

Fig. 111 Projeto Elétrico/iluminação instalado na sala de força facilita a visualização dos pontos de controle - CENU.. 94

Fig. 112 Sala de força controle total dos 3500 pontos de energia da torre Norte - CENU 94

Fig. 113 Sala de instalações hidráulicas e de incêndio - CENU....

Fig. 114 Instalações hidráulicas do Hilton sob o forro removível - CENU

Fig. 115 Identificação dos extintores de incêndio e chave de acionamento de alarme - CENU......

Fig. 116 Funcionamento do Sistema de ar-condicionado

Fig. 117 Caixa de VAV

Fig. 118 Torres de Resfriamento - CENU

Fig. 119 Central de controle de condicionamento - CENU

Fig. 120 Esquema de passagem do cabeamento estruturado 104

Fig. 121 Microcâmera 106

Fig. 122 Sala de controle das Câmeras - CENU SP 107

Fig. 123 Fechadura High Tech com sistema de códigos .110

Fig. 124 Planta da área de elevadores 114 
Fig. 125 Esquema das paradas dos elevadores - CENU-SP.

Fig. 126 Planilha das paradas dos elevadores.

Fig. 127 Elevador de Carga

Fig. 128 Sala de controle dos elevadores

Fig. 129 Interior de um dos elevadores CENU-SP, uso de materiais como granito e aço inox para acabamento........ 115

Fig. 130 Remodelação da cabine do elevador.

Fig. 131 Sistema de triagem - o usuário escolhe o andar de visita antes de acessar o elevador. De imediato o terminal calcula qual carro está mais preparado para atender a chamada e indica ao usuário o número do elevador disponivel, eliminando a botoeira interna e reduzindo o tempo das operações. 


\section{RESUMO}

Neves, R. P. A. A. (2002). Espaços Arquitetônicos de Alta Tecnologia: Os Edifícios Inteligentes, São Carlos, 2002. Dissertação de Mestrado - Escola de Engenharia de São Carlos, Universidade de São Paulo.

O presente trabalho destinou-se a fazer o estado da arte dos Edifícios Inteligentes, estudando os casos mais recentes e significativos e enfatizando as tecnologias utilizadas, sejam os sistemas com os novos materiais, equipamentos, o hardware e software; sejam os serviços que tais sistemas permitem, ou ainda as ferramentas de gestão tecnológica dos sistemas, elementos estes que só podem ser viáveis em função da utilização das novas tecnologias da Telemática.

Para entendimento do assunto, faz-se um levantamento cronológico dos casos existentes internacional e nacionalmente até os dias atuais e uma breve definição conceitual que visa clareza na comunicação com os leitores.

No estudo de casos foram pesquisados quatro edifícios localizados na grande São Paulo. Aspectos como: projetos arquitetônico, urbanístico e dos postos de trabalho (com enfoque na produção direcionada aos edifícios de escritórios); características dos sistemas e serviços de automação predial e de gestão tecnológica e empresarial foram estudados profundamente.

Os Edifícios Inteligentes são observados como suportes de serviços altamente tecnológicos, que estabelecem contato entre o "mundo virtual" dos controles automatizados e os cidadãos, e como indutores de modificações da vida cotidiana, o que produz reflexos no espaço físico da cidade.

Palavras-chave: alta tecnologia, Edifícios Inteligentes, automação predial, Telemática. 


\section{ABSTRACT}

Neves, R. P. A. A. (2002) Architetonics spaces of high technologie: The inteligent buildings, São Carlos, 2002. Masters Dissertation - São Carlos's Engineering School, University of São Paulo.

The present assignement is intended to produce a state of art of inteligent buildings, studying the most recent and significant cases and also emphatising the technologie utilized, systems with new materials, equipments, hardwares and softwares; or even the services allowed by such systems, yet, the tools of systems technologic management. Such elements can only be feasibles by the utilisation of new telemathic's technologies.

For a good understanding of this subject, we did a chronologic survey based on nattional and international existing cases till nowadays and a brief concept definition intended to make a clear communication with the readers.

On this study of cases, four buildings located at São Paulo were researched. Aspects such as architetonics, urbanistics and work stations projects (with emphasis on production directed to offices buildings), systems and service's characteristics from building automation, technologic management and entrepeneurial aspects were deeply studied.

Inteligent buildings are observed as highly technological service supports with establish contact between the "virtual world" from automatized controls and citizens, and as inductores of daily life modifications, producing reflexes on the city's physical spaces.

Key words: high technologie, inteligent buildings, building automation, telemathic. 
1 Contextualização da Pesquisa 


\subsection{Introdução}

A evolução da computação e dos sistemas digitais tem viabilizado aplicações que a princípio causam impactos, mas logo estão presentes no cotidiano das pessoas e passam a ser condicionantes de conforto e da praticidade.

Assim, novos produtos e serviços estão sendo exigidos nos escritórios e residências. Observam-se mudanças na Arquitetura, tanto na organização e utilização do espaço, quanto no projeto das instalações e nos ambientes das edificações.

Tais mudanças estão sendo pensadas e/ou projetadas na forma dos Edifícios de Alta Tecnologia ou Edifícios Inteligentes. CASTRO NETO (1994), sugere a definição, seguindo O IBI (Intelligent Buildings Institute dos EUA), de que os El/EAT são aqueles edifícios "que oferecem um ambiente produtivo e econômico através da otimização de quatro elementos básicos: Estrutura (componentes estruturais do edifício, elementos de Arquitetura, acabamentos de interiores e móveis), Sistemas (controle de ambiente, calefação, ventilação, ar-condicionado, luz, segurança e energia elétrica), Serviços (comunicação de voz, dados, imagens, limpeza) e Gerenciamento (ferramentas para controlar o edifício), bem como das inter-relações entre eles".

Os motivos que impulsionaram a expansão da automação nas edificações foram principalmente à procura de fórmulas para economia de energia, juntamente com a administração eficaz do seu consumo além da grande redução nos custos dos equipamentos de informática.

Além destes fatos originais, atualmente se acresce a necessidade de transmissão de voz, dados, textos e imagens, uma conseqüência da generalização e extensão da informática na vida cotidiana da produção, e ainda o controle sobre o movimento de pessoas e objetos no edifício, necessário devido aos problemas de segurança nas grandes cidades.

A conseqüência destes novos processos sociais impõe uma análise profunda dos serviços que devem fazer parte da infra-estrutura básica do edifício e que devem ser oferecidos aos usuários.

Hoje em dia, a maioria dos edifícios possui uma quantidade de instalações e serviços como instalações elétricas, iluminação, linhas telefônicas e elevadores. Em muitos casos, acrescentam-se sistemas mais sofisticados, tais como rede de computadores, acondicionamento ambiental, controle de acessos, detecção e prevenção de incêndios, proteção patrimonial e outros.

Entretanto, observamos que na maioria dos casos, tais instalações e serviços funcionam de maneira totalmente independente umas das outras, sendo geralmente instaladas em etapas distintas da vida do edifício, adaptando-se 
deste modo à situação existente sem influenciar na sua concepção arquitetônica ou construtiva.

A partir desta realidade e graças às novas tecnologias da informação e das comunicações - Telemática, surge uma nova forma de construir, adotada nos modernos edifícios, nos quais se observa uma nova Arquitetura. Agora, a Arquitetura deve se adaptar ao desenvolvimento destas tecnologias, integrando às instalações tradicionais as novas potencialidades de aplicações.

O incremento qualitativo nas condições ambientais poderá ser conseguido através da distribuição do controle aos próprios usuários, isto é, se o indivíduo tiver autonomia para escolher no ambiente de trabalho ou doméstico, a sua temperatura ou a sua iluminação, por exemplo, ele certamente as configurará da maneira que mais lhe agradar.

Além dos benefícios apontados pode ser citada a taxa condominial dos modernos edifícios do novo centro financeiro da cidade de São Paulo, na Marginal Pinheiros, que é menor que a taxa condominial dos antigos prédios do centro velho da cidade, que não dispõem de sistemas avançados de controle.

A preocupação atual dos projetistas é no sentido de que se faça a previsão de espaços na concepção do projeto, para a utilização de equipamentos inteligentes.

A identificação e caracterização de tais equipamentos, revelando sua importância no contexto de uma residência ou edifício, nos permitem conhecer o processo de estruturação dos novos espaços, gerados no âmbito dos chamados edifícios de alta tecnologia.

Concluindo, pode-se afirmar que qualquer edificação que queira competir no mercado imobiliário dos grandes centros urbanos, deverá contar com algum nível de automação, isto é, a automação predial deverá ser realidade em grande parte das edificações dentro de um tempo relativamente curto.

Neste trabalho, os Edifícios Inteligentes (em especial os de escritórios), serão observados como suporte de serviços altamente tecnológicos, que estabelecem contato entre o 'mundo virtual' dos controles automatizados e os cidadãos, e também indutores de modificações da vida cotidiana, o que produz reflexos no espaço físico da cidade.

Como pudemos observar, o tema em questão torna-se bastante complexo quando estudado em profundidade, e por isso necessariamente teremos que estabelecer diretrizes a fim de pontuar o real objetivo deste trabalho. 


\subsection{Objetivos}

Estudo dos Espaços Arquitetônicos de Alta Tecnologia, visando chegar a uma tipologia das necessidades espaciais e tecnológicas, de gerenciamento e de serviços suportados pela Telemática, fazendo um quadro dos principais conceitos teóricos necessários para o entendimento do assunto, além de uma análise de alguns casos nacionais significativos.

É dentro desta linha geral que se situa a nossa proposta. Destacamos a ocorrência das interfaces entre tais temáticas arquitetônicas e tecnológicas, explicitando o caso dos chamados Edifícios Inteligentes: Hotéis de Convenções (que utilizam tecnologias como teleconferência ou tradução simultânea), Flats (apartamentos de grupos sociais que estão fazendo o teletrabalho (executivos, consultores técnicos, professores, entre outros)), e mais recentemente, os Edifícios Multifuncionais. Estes últimos agregam habitação, espaços para negócios, convenções, entretenimento, lazer, constituindo verdadeiros complexos de espaços arquitetônicos multifuncionais, com exigências de serviços sofisticados e precisos, os quais demandam um gerenciamento específico e de conjunto que só pode ser viável com a utilização das novas tecnologias da Telemática.

Referente ao estudo dos conceitos, faremos um roteiro dos pontos que devem ser considerados desde o projeto até a finalização da obra, de acordo com a função do edifício, para que ele se torne realmente inteligente.

\subsection{Metodologia}

A estratégia metodológica utilizou os seguintes meios para obtenção das informações necessárias à pesquisa:

- Participação nas discussões desenvolvidas junto ao grupo de pesquisa Eurb, sob a coordenação do Prof. Dr. Azael Rangel Camargo, sediado no Departamento de Arquitetura e Urbanismo da EESC/USP;

- Participação em vários seminários sobre assuntos relacionados à Telemática,

- Pesquisa bibliográfica teórica e empírica;

- Pesquisas na Internet,

- Leitura de projetos, de mapas e fotografias;

- Entrevistas com profissionais do ramo, como: arquitetos, construtores, engenheiros, realizadas pessoalmente, por telefone ou via e-mail;

- Visitas aos Edifícios Inteligentes da cidade de São Paulo.

- Mapeamento da localização dos Edifícios Inteligentes em São Paulo.

- Visita aos sites da Web de alguns dos Edifícios pesquisados. 
É oportuno ressaltar que recentemente foram publicados vários trabalhos dedicados ao estudo de Edifícios Inteligentes com a incorporação de modelos particulares sugeridos para escritórios ou residências. Mesmo assim, há escassez de referências bibliográficas.

\section{Critérios para Seleção}

Destacamos também os seguintes critérios para a escolha dos edifícios a serem pesquisados no campo, objeto do nosso estudo de casos:

- Localização

- Utilização - ESCRITÓRIOS

- Emprego de Alta Tecnologia em:

$\checkmark$ Concepção do Projeto

$\checkmark$ Métodos Construtivos

$\checkmark$ Materiais

$\checkmark$ Equipamentos

$\checkmark \quad$ Mão de obra

As informações específicas sobre Arquitetura destes Edifícios, foram obtidas através de:

- Pesquisa em revistas Técnicas e de Arquitetura;

- Preparação de material iconográfico atualizado;

- Entrevistas com arquitetos e engenheiros que trabalham com edifícios Inteligentes.

Para desenvolvimento deste trabalho foi feita uma seleção entre alguns dos edifícios da cidade de São Paulo, que se enquadram dentro das características já citadas. São eles:

- World Trade Center - SP

- Plaza Centenário

- Birmann 21

- Edifício Centro Empresarial Nações Unidas 


\subsection{Estrutura e Síntese do Conteúdo da Dissertação}

A seqüência dos capítulos foi organizada da seguinte maneira:

Iniciaremos nossa análise propriamente dita no segundo capítulo que trata dos Estudos Iniciais onde se faz um relato sobre a evolução histórica do Edifício Inteligente, destacando-se as obras que contribuíram para a disseminação do Edifício Inteligente no mundo e no Brasil. Apresentam-se também alguns dos conceitos utilizados na área de alta tecnologia.

No terceiro capítulo tratam-se diretamente das questões da espacialidade do Edifício Inteligente, enfoca-se a "nova forma de pensar e projetar" dos arquitetos e calculistas, analisando os diversos projetos (arquitetônico, postos de trabalho, urbanístico e paisagístico) que fazem parte de um Edifício Inteligente. É feito também um breve histórico sobre a evolução dos escritórios.

Os aspectos projetuais e construtivos necessários para dar abrigo às novas tecnologias são tratados no quarto capítulo.

A organização dos serviços tais como segurança, iluminação, condicionamento ambiental e outros, bem como a integração entre eles são observadas no quinto capítulo.

No sexto capítulo são tratados aspectos como gestão da produção, gestão administrativa no âmbito predial e investimentos na área de alta tecnologia. No sétimo e último capítulo são observadas as conclusões do trabalho e também são feitas algumas observações sobre o assunto. 
2 Estudos Iniciais 


\subsection{Evolução Histórica}

O edifício constitui o produto mais característico da Arquitetura. É através dele que a Arquitetura se relaciona com a vida dos homens em suas diversas manifestações. Do nascimento à morte, da maternidade ao túmulo, o homem atravessa o tempo da sua existência trabalhando, repousando, cultivando divindades e memórias, brincando e sofrendo no abrigo dos edifícios construídos para proteger e favorecer o exercício das atividades que a vida requer.

A rigor, o edifício é apenas uma construção de alvenaria ou outro material resistente, mas não são as paredes, pisos, tetos e elementos construtivos que definem suas qualidades específicas e essenciais. Tais elementos só são realmente importantes na medida em que geram, delimitam, organizam, ordenam e animam o espaço arquitetônico. Assim, ao falarmos dos edifícios, temos em vista principalmente os espaços que eles definem. O espaço arquitetônico apresenta duas modalidades: espaço edificado e espaço urbano. Entre um e outro não há diferenças essenciais, mas a distinção é útil para efeitos de estudo e melhor conhecimento do espaço arquitetônico.

Entende-se por espaço edificado aquele que está contido no edifício. Esta modalidade do espaço arquitetônico identifica-se, em certa medida, com a noção de espaço interno, de largo uso entre teóricos e historiadores da Arquitetura.

O edifício ao ser erguido, além de envolver uma certa porção de espaço, exerce influência sobre as adjacências. Ele constitui uma presença, um objeto ocupando um lugar e se relaciona com outros objetos como o solo, as árvores, a paisagem e outros edifícios. Ele projeta sombras, apara o vento, modifica a "atmosfera" local.

Nessa presença dos edifícios, nesse relacionamento entre eles e deles com acidentes naturais, lança raízes à idéia de espaço urbano, que se identifica, em certa medida, com a noção de espaço externo.

Verifica-se, então, que, embora nem sempre seja o aspecto mais importante do espaço arquitetônico, o edifício constitui condição necessária e indispensável à sua existência, quer sob a forma de espaço edificado, quer sob a forma de espaço urbano.

\section{Edifício Alto ou Arranha-Céu}

Designa todo edifício, seja de apartamentos, seja de escritórios ou de finalidade mista, que se eleve muito acima do nível do chão. Via de regra, não se considera incluído na categoria de arranha-céu o edifício de menos de dez andares. Da mesma forma, não se enquadra nessa designação a construção, por mais alta que seja, e que não se destine a proporcionar residências ou escritório. Um obelisco altíssimo, como, por exemplo, o monumento a Washington, em Washington, não é propriamente um 
arranha-céu, como também não é a Torre Eiffel, de Paris, nem a pirâmide de Quéops, no Egito.

A conveniência da construção de edifícios residenciais e de escritórios muito altos resultou da necessidade de se aproveitar melhor a área dos terrenos das zonas citadinas mais centrais. Sendo objeto de intensa competição no capítulo da compra e venda, esses terrenos sobem tanto de preço, que a única forma de se extrair deles um rendimento que compense o custo, é aproveitá-los em altura. Porém, está claro, , que só se verifica o fenômeno da competição intensa nas cidades em fase de crescimento muito rápido, pouco importando que sejam novas ou velhas. Isso explica o motivo pelo qual o arranha-céu é construção típica da América.

Antes da construção do arranha-céu, três problemas tiveram de ser solucionados:

Em primeiro lugar, foi preciso resolver-se o caso do transporte vertical, porque os usuários se recusavam a subir longos e numerosos lances de escadaria e a solução foi o elevador;

Em segundo lugar, o emprego de fundações suficientemente robustas, o que se solucionou com a ciência da exploração do subsolo e com a técnica do estaqueamento do terreno;

Por último, solucionar a utilização das paredes muito grossas, que ocupavam muito espaço, o que se solucionou com o aparecimento do concreto armado e das estruturas metálicas.

Um dos primeiros arranha-céus que se construíram, ainda com a antiga técnica dos edifícios de alvenaria, mas já dotado de elevadores, foi o Montauk, de dez andares, de Chicago, inaugurado em 1882.

O primeiro arranha-céu de estrutura metálica sem paredes portantes foi a sede da Home Insurance Company, construído em 1884, em Chicago, demolido em 1931. Outro arranha-céu de notáveis proporções foi o Tacoma, também de Chicago, concluído em 1889 com treze andares.

Em 1891, projetou-se em Nova York o Fraternity Temple, com 35 andares, com recuos dos andares superiores em relação ao prumo da fachada, a fim de permitir maior iluminação natural. O projeto nunca foi levado ao término, mas foi ele, na verdade, que estabeleceu o princípio dos recuos dos andares superiores dos edifícios muito altos, atualmente obrigatórios por lei.

Deve-se notar que, no começo, a Arquitetura do arranha-céu não progrediu com a mesma rapidez da sua engenharia. Os primeiros edifícios desta categoria apresentaram fachadas do tipo dos palácios da Renascença Italiana - como se fossem casas superpostas umas às outras. Esta fase se caracterizou pelo Edifício Flatiron, de Nova York. A seguir, os arquitetos se inclinaram para o tipo de torre, à maneira da Renascença Francesa. A característica desta fase foi o edifício Singer, de Nova York, com 47 andares. Mais ou menos ao mesmo tempo, surgiu o edifício da Metropolitan Life 
Insurance, que, embora sendo obra de arquitetos de mentalidade francesa, se aproximou das linhas do Campanário de S. Marcos, de Veneza. Posteriormente revelou-se a tendência dos arranha-céus para o estilo gótico, de que são exemplos o edifício Woolworth, com 58 andares, de Nova York, que data de 1912, e o edifício de Chicago Tribune, de Chicago, que data de 1923.

De 1920 para diante, com as conquistas da arte moderna de um lado, e das técnicas da construção de outro, consolidou-se o conceito do arranha-céu, que passou a ser altíssimo, de linhas simples e elegantes, praticamente destituído de qualquer ornamentação propriamente dita, e ganhou o efeito decorativo do acerto da funcionalidade de sua conformação. Surgiram assim os autênticos arranha-céus norte-americanos, como o Empire State, o Chrysler, o Rockefeller Center, seguidos por infinito número de outros, de menor estatura (mas sempre de grande importância), em outros países, como por exemplo o edifício do Ministério da Educação e Cultura, no Rio de Janeiro, Brasil.

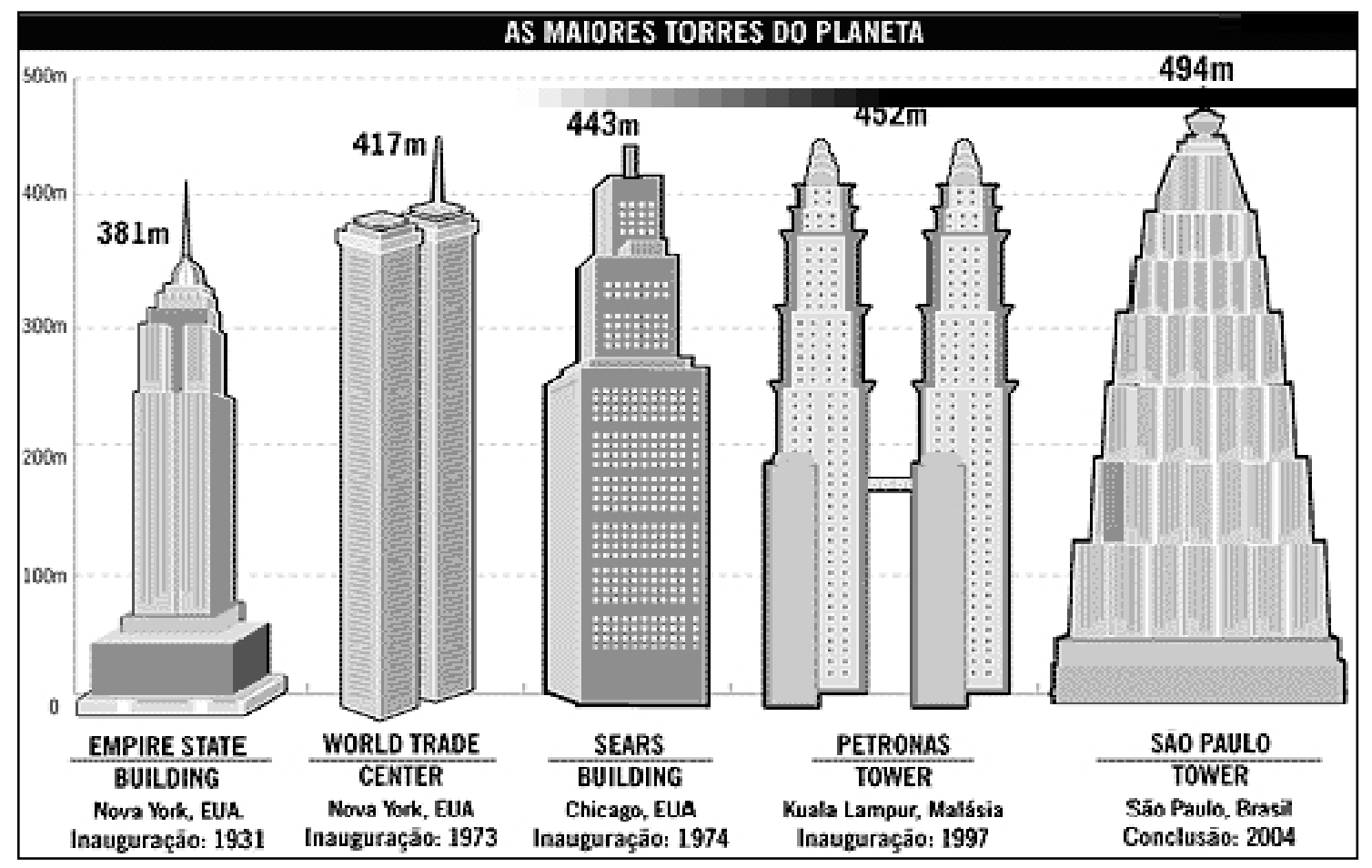

Fig. 1 As maiores torres do planeta

Fonte: http://images.google.com 


\section{Os Edifícios Inteligentes}

Nos finais dos anos 70, os sistemas HVAC (Sistema de Aquecimento, Ventilação e Ar Condicionado) foram os primeiros sistemas de edifícios a serem eletronicamente controlados. Os chips de computadores permitiram o controle destes sistemas, através de sensores localizados, permitindo respostas e alterações rápidas e mais precisas das condições climáticas. Esta tecnologia fomentou o início do desenvolvimento da idéia de tornar os edifícios dotados de inteligência, podendo assim responder aos requisitos do ambiente natural, mas não existia integração alguma.

O conceito de "smart building" apareceu nos EUA por volta da década de 80. Por definição, um Edifício Inteligente é aquele que utiliza a tecnologia para diminuir os custos operacionais, eliminar os desperdícios e criar uma infra-estrutura adequada para aumentar a produtividade dos usuários. Também nos anos 80, apareceram os sistemas de automação de segurança e iluminação, mostrando coordenação entre componentes do mesmo sistema.

Com a crise energética, várias alternativas foram utilizadas para reduzir o consumo. Após constatação de que 1/3 da energia utilizada no mundo era consumida pela construção civil, mais precisamente pelo setor de edificações (Landero, 1989), surgiu a necessidade de uma administração mais eficaz desta energia através da utilização dos recursos tecnológicos que estavam em plena ascensão. Surgem os primeiros edifícios com sistemas automatizados.

O interesse em contabilizar os edifícios que possuíam algum sistema de controle automatizado surgiu em 1968, pelo American Institute of Architects (Castro Neto, 1994), que neste mesmo ano chegou a um significativo número de 550 edifícios. Em 1976 foi realizada uma nova pesquisa na qual foram contabilizados 2.132 edifícios com diferentes níveis de automação no mundo.

Marte,(1995) afirma que atualmente não se concebe um edifício (até mesmo os residenciais, onde os requisitos de economia energética, segurança e comunicações, são menores), que não possua sistemas automatizados quer seja para seu gerenciamento quer para a segurança, levando-se em conta que o desenvolvimento das comunicações e dos sistemas de automação de escritórios praticamente obriga a utilizar recursos tecnológicos de ponta.

\section{A Realidade dos Edifícios Inteligentes}

Alguns anos depois da fase de aparecimento no mercado dos ditos "Edifícios Inteligentes", quando surgiram "kits" para novos edifícios, a tecnologia de controle foi se desenvolvendo até a ponto de ser possível promover estruturas que realmente merecessem o nome que lhes foi atribuído. Entretanto, o uso e abuso deste título produziram reações nos proprietários 
dos edifícios, patrocinadores e grupos financeiros, os quais concluíram que aquilo que lhes foi proposto não seria adequado às funções por eles pretendidas. Como resultado, alguns dos grandes grupos de desenvolvimento tecnológico neste campo, emigraram para outros tipos de infra-estruturas e sistemas tecnológicos. Como exemplo, pode-se citar que algumas empresas estão fornecendo sistemas integrados para edifícios, com o objetivo de oferecer um sistema de controle em que, para serviços diferentes num edifício, a sua organização e integração têm como fundamento a obtenção de operações comuns.

Um exemplo específico pode ser um circuito fechado de televisão. Quando é acionado um alarme pelo sistema detector de incêndios, pode-se visualizar se existe realmente um incêndio ou só um falso alarme. Neste caso, teríamos integração de sistemas entre a detecção de incêndios, alarmes e o circuito de vídeo interno. Mesmo sendo o hardware fornecido por empresas diferentes, isso não diminui a integração, já que é feita através do software.

Devemos ter muito cuidado com o termo "Edifício Inteligente", por ter sido um termo de marketing sem muita substância desde que foi introduzido no mercado. O problema foi o número excessivo de empresas que comercializa os sistemas para Edifícios Inteligentes. O mercado saturou rapidamente e a realidade não estava lá. Um Edifício Inteligente é aquele que promove a transferência de dados de um sistema para outro.

Imaginemos a leitura de um cartão de acesso a um Edifício Inteligente por um usuário qualquer. Depois de dar permissão de entrar no edifício, o leitor de cartões magnéticos envia um comando ao sistema de climatização do escritório ou compartimento desse usuário, acionando-o e ativando ao mesmo tempo o sistema de elevadores relacionados com o local de entrada e o compartimento utilizado pelo usuário com o objetivo de poupar energia e realizar uma gestão racional de energia elétrica. Usuários individuais poderão estar providos com um cartão ativo, o qual pode ser lido por sensores localizados em locais estratégicos e espaçados do edifício. Desta maneira pode-se, além de outras funções, encaminhar às chamadas telefônicas para o compartimento onde 0 indivíduo se encontra, ou encaminhando-as para um sistema de mensagens caso esse cartão não seja detectado.

Estes sistemas terão de ter suporte técnico 24 horas por dia, no caso de surgirem problemas. Não há razão em ter todos estes sistemas e facilidades se o não pudermos suportar tecnicamente. Quando temos uma falha no controle no sistema, pode ser ao nível do software ou eletrônico. Qualquer um deles pode, na maioria dos casos, ser remotamente resolvido. No caso de ser um problema mecânico, pode-se detectá-lo da mesma forma. Podese dizer que 90 ou $95 \%$ dos problemas detectados em horas fora do expediente podem ser resolvidos através de um modem.

Um dos aspectos mais importantes para compreender os sistemas dos Edifícios Inteligentes, no que diz respeito aos seus proprietários e utilizadores, é a facilidade do controle de manutenção. Os edifícios podem ser 
eventualmente capazes de promover relatórios detalhados do seu estado de conservação e reparação. "Uma das funções mais importantes dos Edifícios Inteligentes é a capacidade de poderem nos fornecer o seu estado" afirma o presidente da Jim Service. "A tecnologia é mais avançada quando disponibiliza ou monitora o seu próprio estado". Se nós vamos avançar para um regime de manutenção planejada, haverá maiores benefícios para o proprietário, benefícios esses que nos irão ajudar a desenvolver novas tecnologias graças à credibilidade fundamentada pelas anteriores.

No Brasil, o software mais utilizado em edifícios desse tipo é o da Building Management System (BMS) que comanda todas as funções prediais.

\section{Desenvolvimentos Atuais}

Nos dias de hoje, surge a segunda geração de Edifícios Inteligentes, os quais possibilitam integração e separação dos sistemas com o auxílio das avançadas tecnologias computacionais e de telecomunicações. O ponto mais forte destes tipos de sistemas é atingido quando são suportados por uma grande base de dados, custos reduzidos, capacidade de processar rapidamente uma quantidade vasta de informação, com a ajuda de um software capaz disso e de ambiente agradável para o usuário, com possibilidade de ser adaptado às novas tecnologias que vão surgindo. Já não se usa a tecnologia, incorpora-se.

A tecnologia é cada vez menos sobre coisas, e cada vez mais sobre relacionamentos. Claro que o relacionamento e interligação inteligente, certamente em escala urbana, é também uma manifestação espacial da economia e das inovações tecnológicas.

Embora estejam fisicamente isolados, os controles de sistemas individuais podem ser regulados por um computador central para otimizar os desempenhos individuais e em conjunto. Por exemplo, ao integrarmos o sistema de detecção de incêndios com o de segurança, podemos destrancar todas as portas de forma a fornecer o caminho mais rápido para as pessoas evacuarem o edifício em caso de emergência. Em conjunto com o sistema HVAC, poderá ser controlado o fluxo de ar e chamas de forma a impedir a sua propagação.

Ao nível dos sistemas de gestão de energia, pode ser regulada a iluminação artificial de acordo com a natural, gestão de energia solar e utilização de sistemas mecânicos para limitar o consumo de energia. Esta nova geração de edifícios está concentrada na sensibilização econômica, ou seja, na gestão de energia, flexibilidade e integração dos sistemas, para além da utilização de coletores solares e turbinas eólicas que permitam um potencial auto-suficiente.

Está demonstrado que com a ajuda destes conceitos o desenvolvimento tecnológico aumentará, abrindo perspectivas para um mundo novo. 


\subsection{Rota dos Pioneiros}

Enumeramos alguns fatos significativos, que evidenciam as primeiras manifestações de concepção dos edifícios de alta tecnologia:

$1904 \Rightarrow 0$ arquiteto norteamericano Frank Loyd Wright considera que o edifício é uma "expressão" diretamente aplicada a seu propósito, igual ao transatlântico, avião ou automóvel". E, de fato, com seu Edifício Larkin, ao isolar os elementos de comunicação e serviços, expressou claramente os aspectos funcionais.

Fig. 2 Edifício Larkin - Búfalo Fonte: http://images.google.

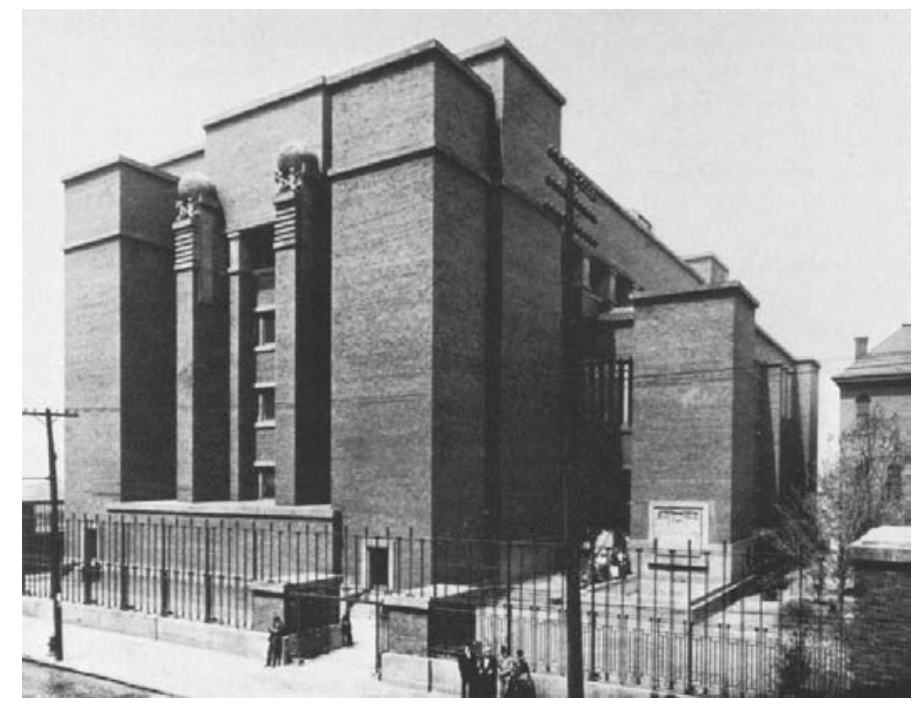
Fig. 3 Átrio central do Edifício Larkin

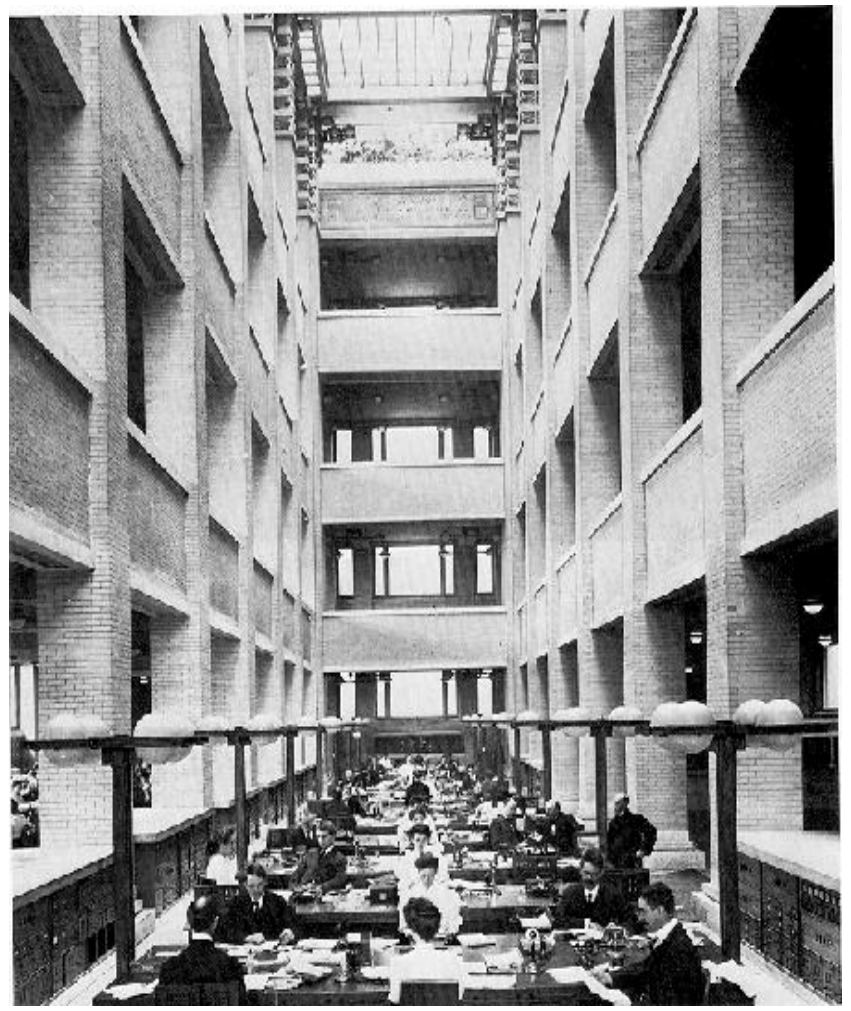

O átrio central com pé-direito elevado iluminado por clarabóia (destinado aos empregados de escalão inferior) é circundado por quatro pavimentos de galerias onde se localizam as salas privativas dos funcionários mais graduados. Quatro torres maciças em cada canto do edifício resolvem, na época de forma inteiramente inédita, as circulações verticais além de outros serviços e facilidades. Pela primeira vez se adota um sistema central de renovação e climatização do ar com dutos embutidos na alvenaria e grelhas de insuflação e retorno. Pela primeira vez também se projeta um mobiliário específico em aço, condizente com a clareza e

racionalidade do desenho geral do edifício.

$1914 \Rightarrow$ Em seu manifesto de "Arquitetura futurista", Antonio San't Elia pedia ao arquiteto que evitasse os materiais pesados, em favor dos flexíveis que permitissem a mobilidade e o dinamismo. A Arquitetura, dizia, não deveria ser permanente, mas efêmera. 


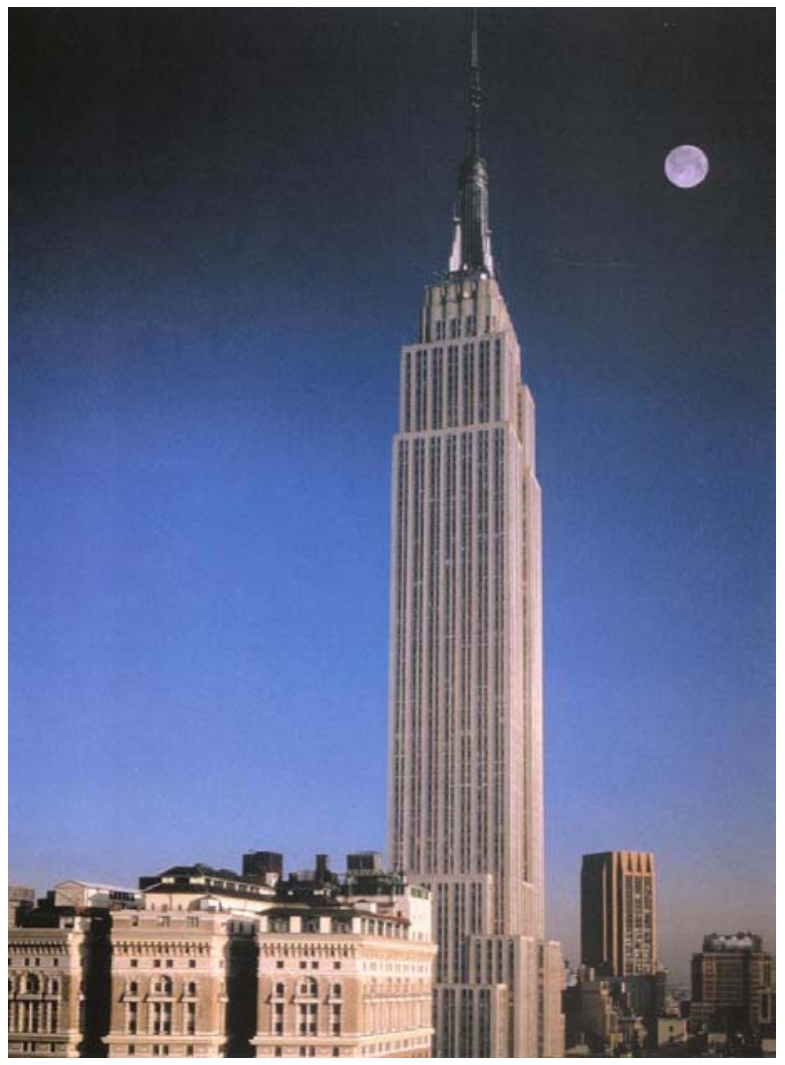

$1931 \Rightarrow$ Concluído O Empire State Building, com um custo de US\$41milhões. Foi projetado pela firma Shreve, Lamb, e Harmon. Com 381 metros de altura, este edifício de escritórios ficou sendo o prédio mais alto do mundo até 1971, quando foi terminada a primeira torre do World Trade Center, também em Nova York.

Fig. 3 Edifício Empire State Building - NY

Fonte: Revista AU no 100 fev/mar 2002

Como O Empire State Building foi concluído durante a época mais difícil da Depressão de 1929, a maioria dos seus escritórios permaneceu vazia durante anos e para poder pagar os impostos sobre o edifício, os proprietários abriram a plataforma de observação ao público.

Utilizou técnicas construtivas bem avançadas para a época,o prédio foi construído em 14 meses. Cinco meses antes do previsto. Iniciou a obra com 3.400 operários.

Possui ainda 73 elevadores, de alta tecnologia para a época, que vão do 10 ao $80^{\circ}$ andar em apenas um minuto.

Dentre as curiosidades sobre o Empire State Building, conta-se que desde sua inauguração até hoje, centenas de pessoas tentaram se jogar do terraço do 860. andar, o único vão aberto do edifício. O vento é tão forte que joga os suicidas de volta para uma marquise. Ninguém morreu até hoje.

Fig. 4 Trabalhadores do ESB - almoço Fonte: http://images.google.com

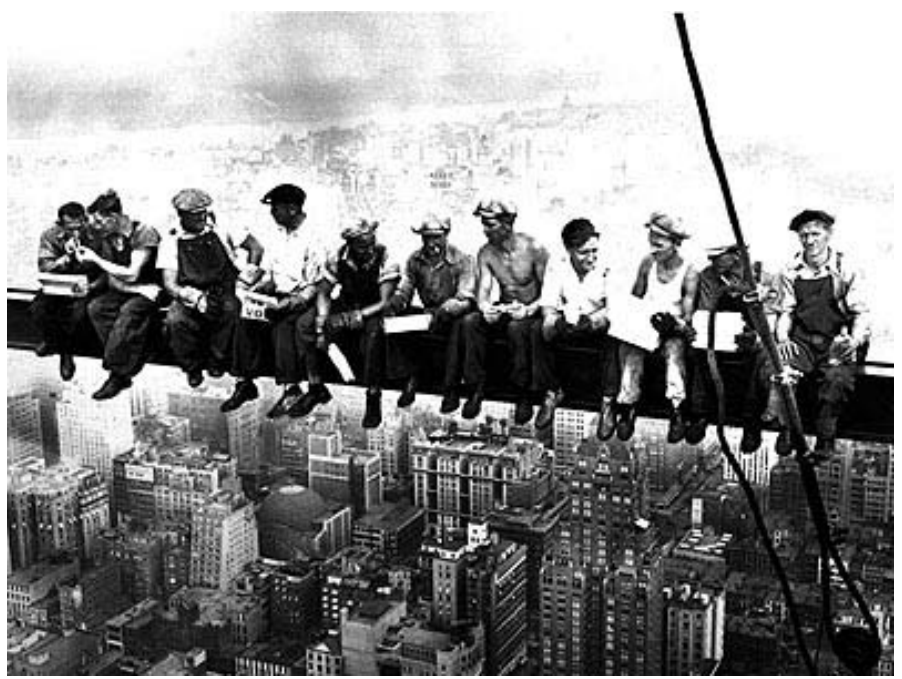

$1950 \Rightarrow$ A Flexibilidade que anunciava Siegfred Giedion, ao falar da necessidade do arquiteto de prever modificações nas edificações, a fim de prestar os serviços que pudessem responder às necessidades dos usuários a cada momento. 
Anos $60 \Rightarrow 0$ grupo dos arquitetos ingleses Archigram previa que a excessiva duração dos edifícios não se acomodava às mudanças tecnológicas e culturais, desenvolvidas em ciclos cada vez mais curtos. Os arquitetos "metabolistas" japoneses propunham isolar os componentes duráveis dos edifícios suscetíveis de sofrer as pressões de mudança.

$1966 \Rightarrow$ Construído o World Trade Center - New York, projeto do Arquiteto Minoro Yamasaki. Considerado um marco não só pela sua Arquitetura com fachadas suntuosas e pilares de estrutura metálica que formando um paliteiro seriam capazes de suportar o impacto de avião de pequeno porte, mas também pelos sistemas automatizados que utilizavam tecnologia de ponta, como por exemplo os elevadores, que eram divididos por baterias a fim de evitar a viagem do primeiro ao último andar, economizando tempo e energia. Não havia no entanto a integração desses sistemas.

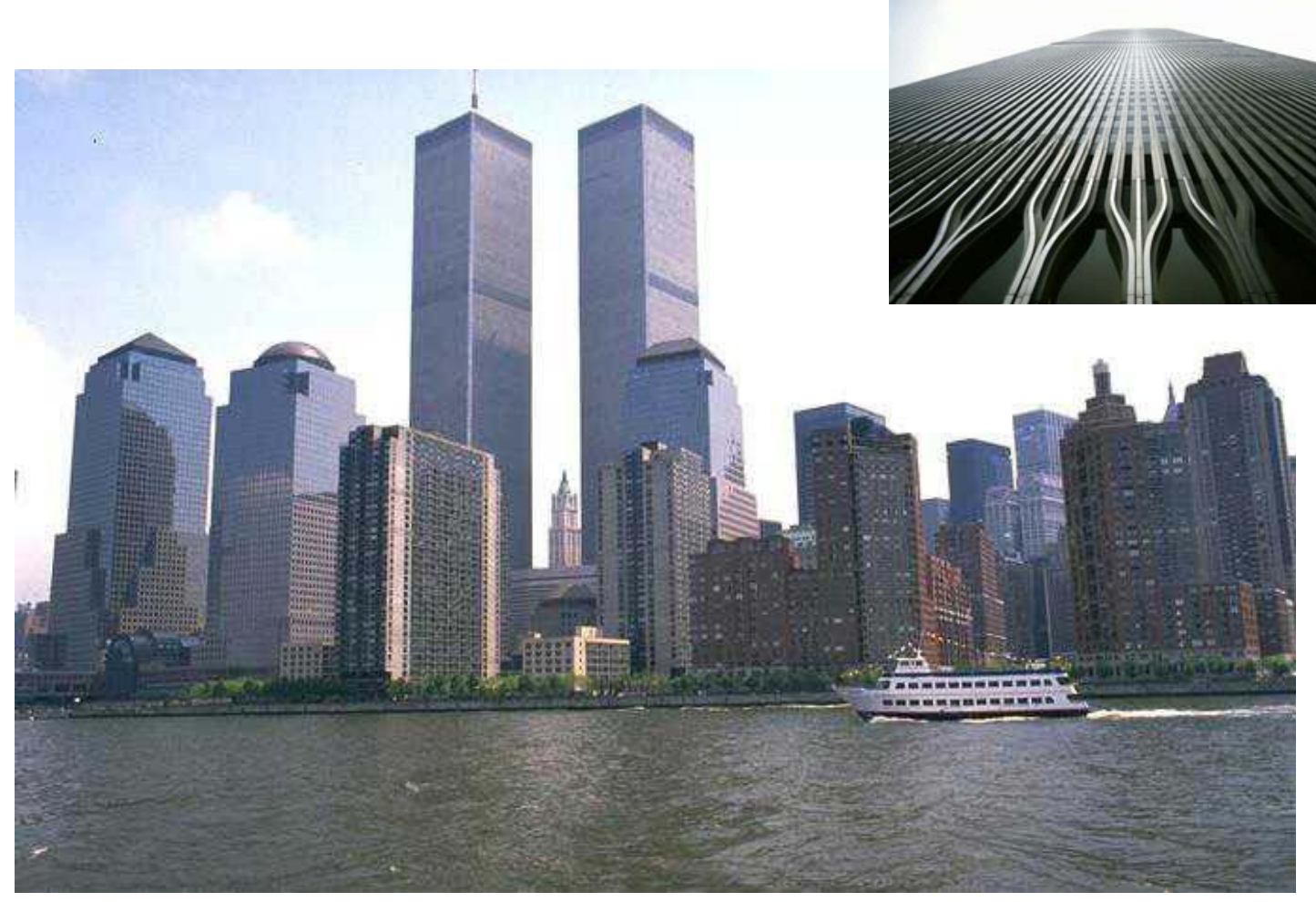

Fig. 5 World Trade Center - NY

Fig. 6 Detalhe da fachada das torres do WTC NY

Fonte: http://images.google.com

O WTC destruído em setembro de 2001, era o símbolo do poder econômico dos EUA. Era composto por duas torres principais com $417 \mathrm{~m}$ de altura e mais cinco edificios menores.

Fig. 7 Planta do complexo WTC - NY

Fonte: http://images.google.com

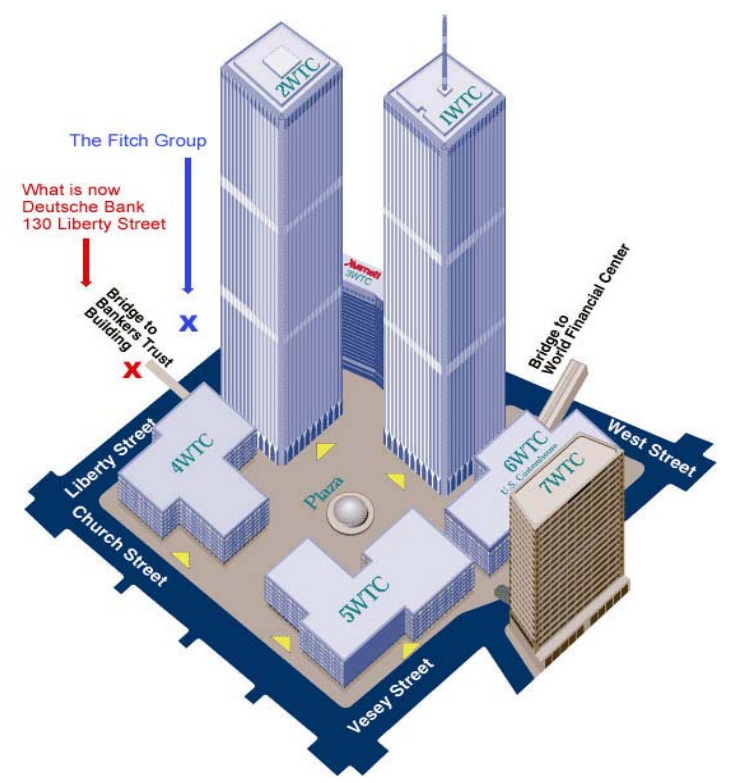


$1973 \Rightarrow$ Com a primeira "crise" do petróleo e a comercialização dos microcomputadores, o mercado estava necessitado: era necessário economizar energia, e os Edifícios Inteligentes se apresentavam como solução economicamente viável.

$1978 \Rightarrow$ Mass United Technologies, em Cambridge - UK, realizou a primeira integração de vários edifícios (134) num só sistema, que controlava 2.400 pontos e custou 5.5 milhões de dólares. Esta quantia ficou amortizada ao cabo de dois anos, contabilizando tão somente a economia energética.

$1982 \Rightarrow$ Realização do primeiro sistema com inteligência distribuída - Painéis Remotos Autônomos -, por U.T.Buildings Services no Epcot - Walt Disneyworld, na Flórida, EUA.

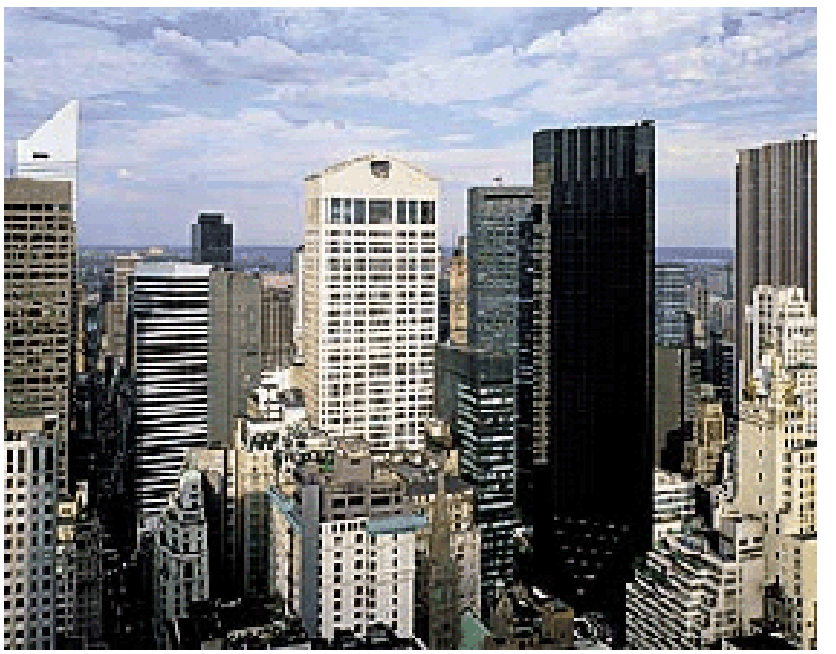

$1984 \Rightarrow$ Foi construído o edifício que é considerado a cabeça dos Edifícios Inteligentes, o edifício da Companhia Telefônica AT\&T, em Nova York, EUA, projetado por Philip Johnson \& John Burgees, que pode ser considerado altamente flexível em sua estrutura.

Fig. 8 Edifício da AT\&T - NY

Fonte:

http://www.pritzkerprize.com/pjohn.htm

$1986 \Rightarrow$ Construído em Londres o edifício da Companhia de Seguros Lloyd's, considerado um modelo de Edifício Inteligente. A intenção deste edifício, flexível como um mecano, conforme seu arquiteto Richard Rogers, é que sua estrutura dure cinqüenta anos; o sistema de ar-condicionado, quinze e as comunicações, cinco. Por isso os equipamentos mecânicos foram colocados

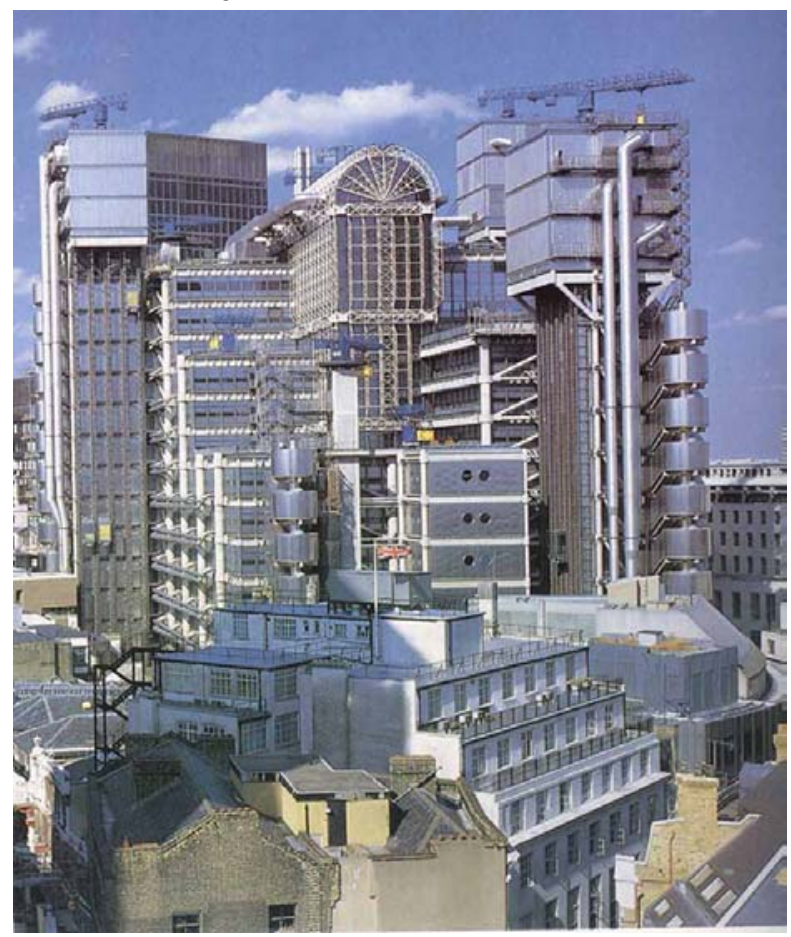
nas torres periféricas, a fim de facilitar o acesso para manutenção e substituição em caso de obsolência.

Fig. 9 Edifício da Lloyd's - Londres

Fig. 10 Planta do edifício Fonte:

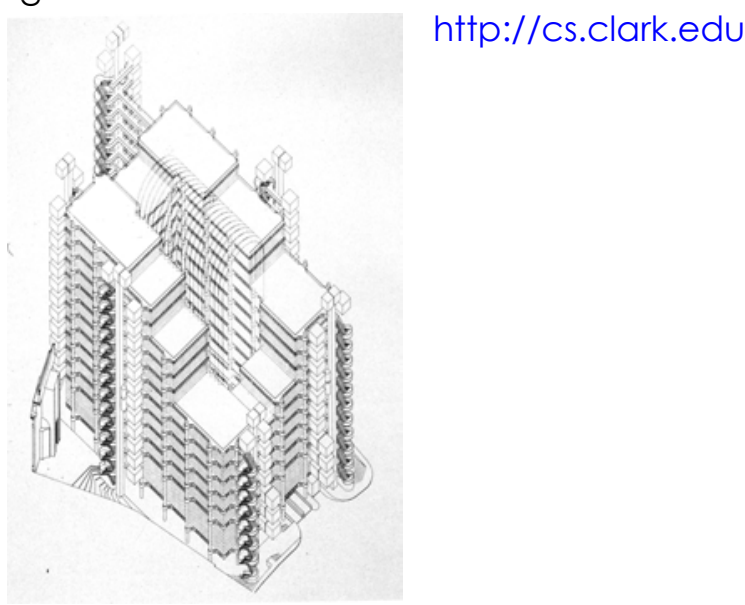




\subsection{Os Pioneiros no Brasil}

No item anterior fez-se uma primeira incursão nas ocorrências dos Edifícios Inteligentes nos casos internacionais até 1986. Após esta data já começamos a encontrar experiências brasileiras.

$1986 \Rightarrow$ Inaugurado $\circ$ edifício Citicorp/Citibank, com 93m de altura e 20 andares. Projeto do Escritório Aflalo e Gasperini, destacou-se no perfil da Paulista não só pela utilização das cores contrastantes dos materiais utilizados no revestimento da fachada (pedra granítica rosa e o vidro azul), como também pelo tratamento arquitetônico de seus volumes e pelo sofisticado tratamento dos interiores. A estrutura é formada por duas grelhas estruturais paralelas suspensas acima do amplo saguão do pavimento terreo através de uma transição estrutural.

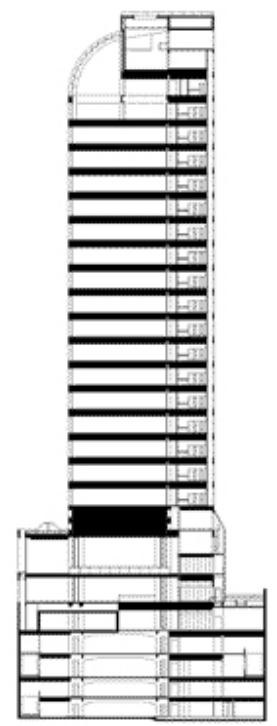

Fig. 11 Sede do Citibank - SP Fonte: arquivo pessoal
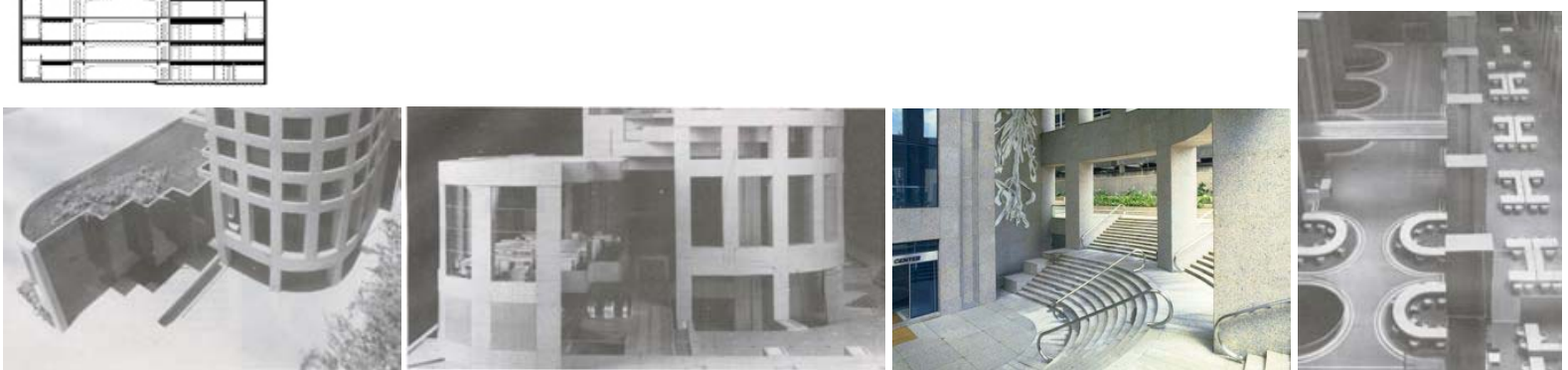

Ele é um dos marcos arquitetônicos da avenida, caracterizando o pósmodernismo dos anos 80. O edifício abriga, além da sede administrativa do Banco Sudameris e sua superintendência, uma agência bancária num anexo com acesso pela Alameda Campinas. Pioneiro também na área das novas tecnologias, com seus 2.500 pontos de supervisão que fazem o gerenciamento de todas as instalações. 
$1986 \Rightarrow$ Construção do Centro Cultural Itaú que, da mesma forma que o exemplo anterior, utiliza em grande parte de seus sistemas, uma tecnologia totalmente nacional. Projeto de Ernest Mange.

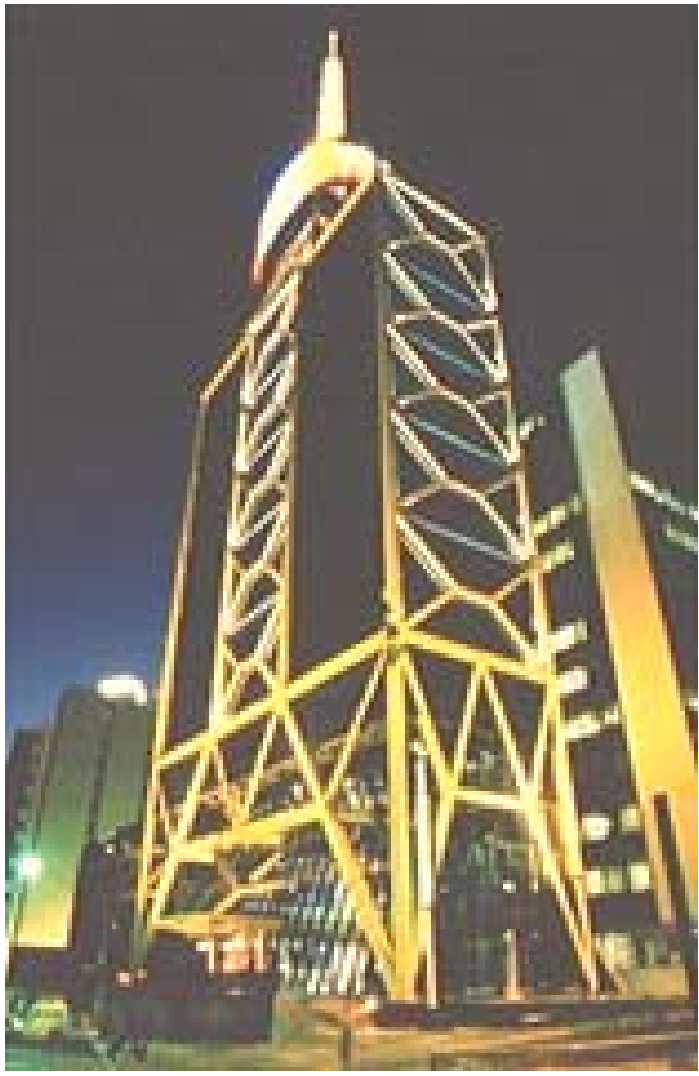

A necessidade do edifício de dispor de pavimentos-tipo em planta livre, de modo a flexibilizar diferentes layouts e ainda a necessidade de vários subsolos para garagem foi solucionada com a utilização de pórticos periféricos contraventados com perfis em " $\mathrm{x}$ " interrompidos por barra, o que dava evidência ao embasamento da edificação como transição estrutural.

Foi utilizada uma tinta especial contra fogo recém-lançada que além de proteger a estrutura metálica deu um aspecto mais esbelto.

Privilegia ainda as tecnologias de ponta como recursos de veiculação de imagens e informações. Emprega tecnologias construtivas e materiais contemporâneos como aço e vidro.

Fig. 18 Edifício Centro Empresarial Itaú

Fonte: http://www.feixe.com.br/clientes.htm

Mantém como uma de suas principais atividades um banco de dados culturais informatizado aberto à consulta de pesquisadores e do grande público; promove exposições e palestras e cursos, edita publicações, lança filmes e vídeos, um verdadeiro museu virtual.

Fig. 19 Planta do 10 pav. (auditório)

Fig. 20 Auditório

Fig. 21 Postos de Consulta Informatizados

Fig. 22 Corte longitudinal

Fonte: Revista Projeto Design no 193 jan/fev 96

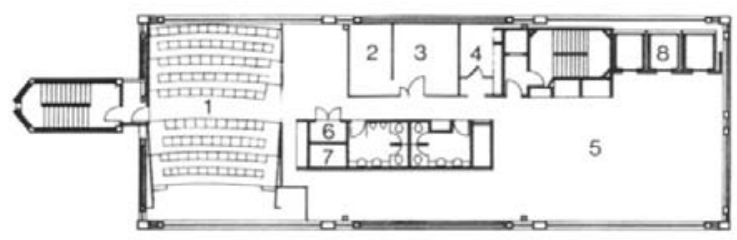

$1^{2}$ andar auditório
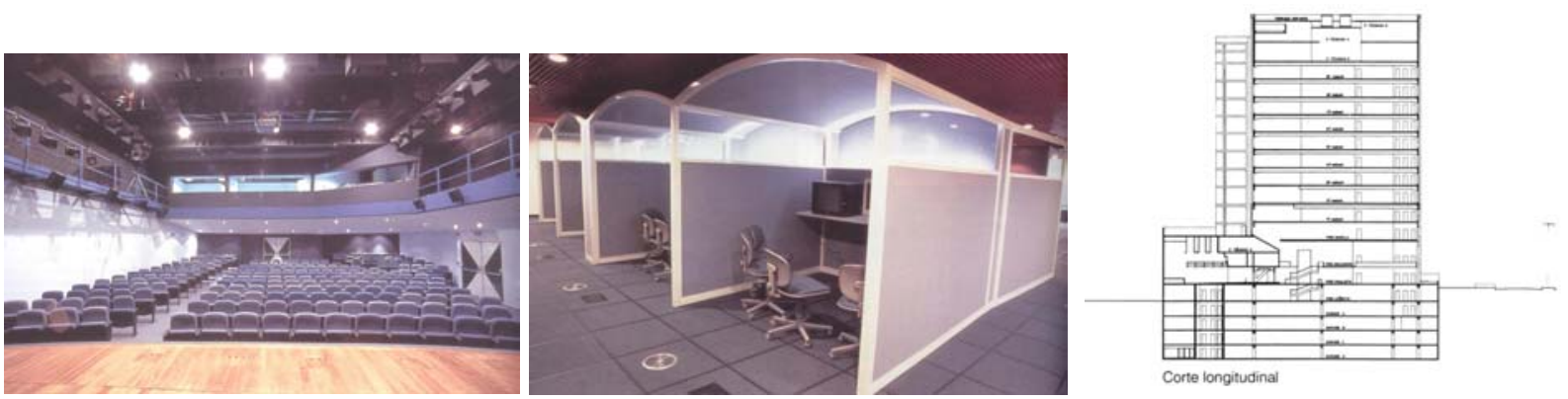
$1987 \Rightarrow$ Projeto do edifício - sede do Grupo Gomes de Almeida Fernandez na avenida Faria Lima, em São Paulo.

$1989 \Rightarrow$ Lançamento do Manhatann Tower, no Rio de Janeiro, do arquiteto Edison Musa. Inaugurando a fase de projetos de alta tecnologia fora de São Paulo.

$1989 \Rightarrow$ Lançamento do Camp Tower, em Campinas, interior de São Paulo.

$1991 \Rightarrow$ Implantação do Sistema de Supervisão, Automação e Gerenciamento do edifício - Sede da Philips em São Paulo, aproveitando toda experiência administrativa acumulada para desenvolver os sistemas, já que o edifício foi construído na década de 80.

1992 $\Rightarrow$ Com o fim da reserva de mercado para produtos informáticos, iniciase a importação de novos produtos e tecnologias, aumentando a oferta, tornando o mercado mais competitivo e, por conseguinte, melhorando a resposta à demanda dos usuários dos edifícios de alta tecnologia.

1993 $\Rightarrow$ Nos anos 90, a tecnologia da construção se desenvolveu sobretudo em fechamentos.

Na estrutura, a grande promessa, o aço, teve poucos adeptos. Exemplo isolado foi o Alfacon Steel Tower, de Luiz Fernando Rocco e Carlos Bratke, cuja montagem estrutural estendeu-se por apenas três meses.

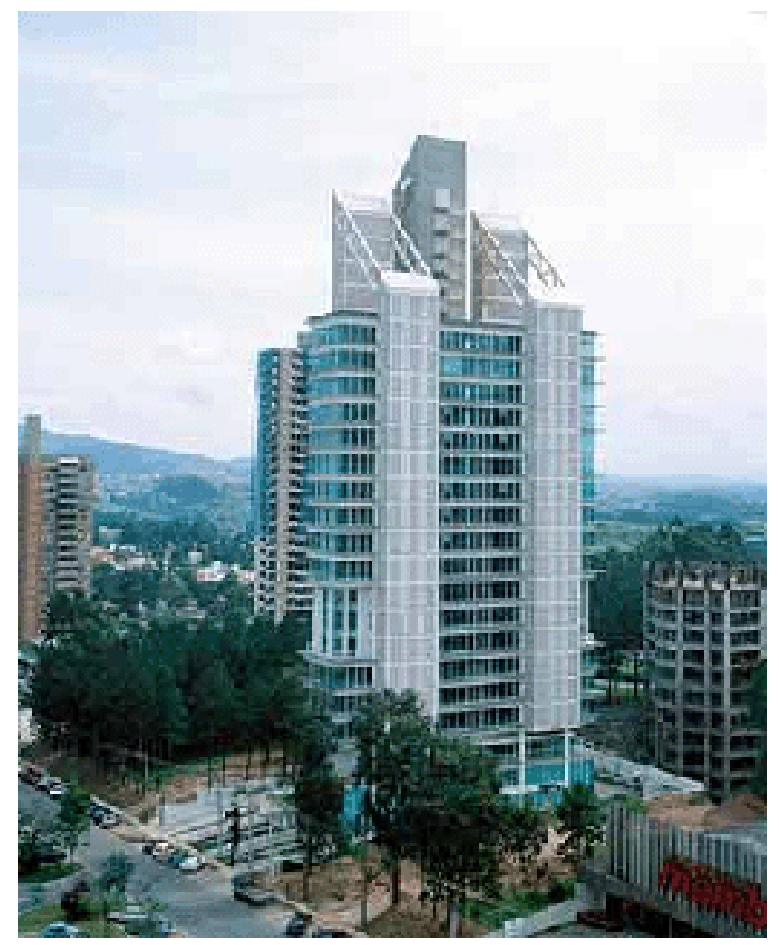

Fig. 23 Edifício Alfacon Steel Tower - SP

Fonte: http://arcoweb.com.br/arquitetura/arquitetura54a.asp 
1994 $\Rightarrow$ Concluído o complexo World Trade Center, dos arquitetos Aflalo \& Gasperini; o complexo WTC é composto de uma torre de escritórios de 26

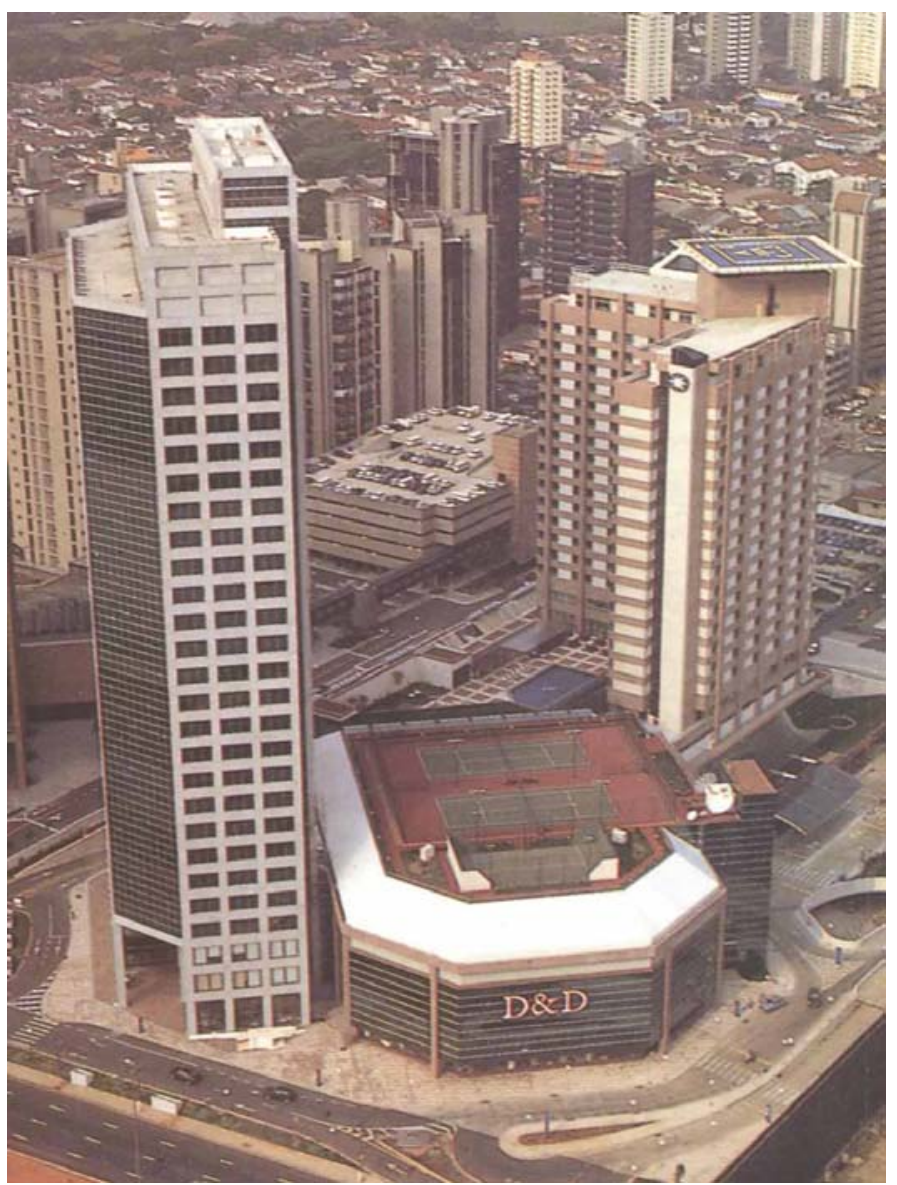
andares que abriga um clube internacional de negócios, áreas de exposição de produtos e escritórios para locação. Os 3 primeiros andares são dedicados a business club que é um núcleo aberto para todos os associados, com salas de trabalho para executivos em trânsito, biblioteca, restaurante e espaços para treinamentos e conferências. $\bigcirc$ complexe conta ainda com um hotel cinco estrelas com 13 andares, um centro de convenções para 2.000 pessoas, um shopping temático de decoração e uma garagem para 2.250 veículos. Fica localizado na marginal Pinheiros, São Paulo e com uma área de $177 \mathrm{mil} \mathrm{m}^{2}$.

Fig. 24 World Trade Center - SP Fonte: Revista AU no 60 jun/jul 95

Todas estas funções foram articuladas numa única solução integrada pela grande área do shopping, no entanto possuem acessos separados.

A área de convenções localizada na área superior do shopping, com ligação direta com o hotel e os escritórios do WTC, permite a realização de vários eventos simultâneos com capacidade para 1.500 pessoas. Um auditório/teatro com 540 lugares completa o conjunto. A área de lazer e de esporte do hotel foi também localizada na cobertura do shopping, à qual se integra através de uma ampla estrutura de vidro.

Mesmo com diferenças claras no programa, que respondem basicamente a adaptações à demanda local, a concepção do empreendimento é a mesma nas suas 259 unidades atuais: centros empresariais ambiciosos, com características multiuso, aproveitando a sinergia entre as áreas diversas para apoiar a realização de negócios internacionais. Para promover o acesso dos seus associados ao mercado internacional, todas as unidades do WTC são dotadas de sistemas de comunicação e recursos de automação de ponta.

No interior, existem painéis de gesso com revestimento acústico, elevadores que operam pelo sistema de zoneamento, canaletas de piso para abrigar as instalações elétricas e de telefonia, sistema de ar-condicionado com controle individual, locais para acesso a portadores de deficiência física, sala 
para videoconferência, 3 elevadores panorâmicos e um capaz de transportar veículos e geradores.

Em termos de infra-estrutura de apoio, o complexo reúne requintes de alta tecnologia e oferece os serviços mais avançados de automação predial. $\bigcirc$ centro de convenções e a torre de escritórios são dotados de uma espinha dorsal de fibra ótica (backbone) para transmissão de dados e imagens em altíssima velocidade.

O sistema de rede comercial exclusiva, interligada à internet veicula em tempo real catálogos e informações sobre compra e venda de produtos a bancos de dados de 160 países e mais de 500 mil empresas.

Outro serviço disponível é a videoconferência, que permite a apresentação simultânea de produtos a todos os WTC, via satélite.

O circuito fechado de tv também possibilita o acompanhamento de eventos realizados no centro de convenções pelos hóspedes do hotel.

O heliponto possui capacidade para receber helicópteros de grande porte.

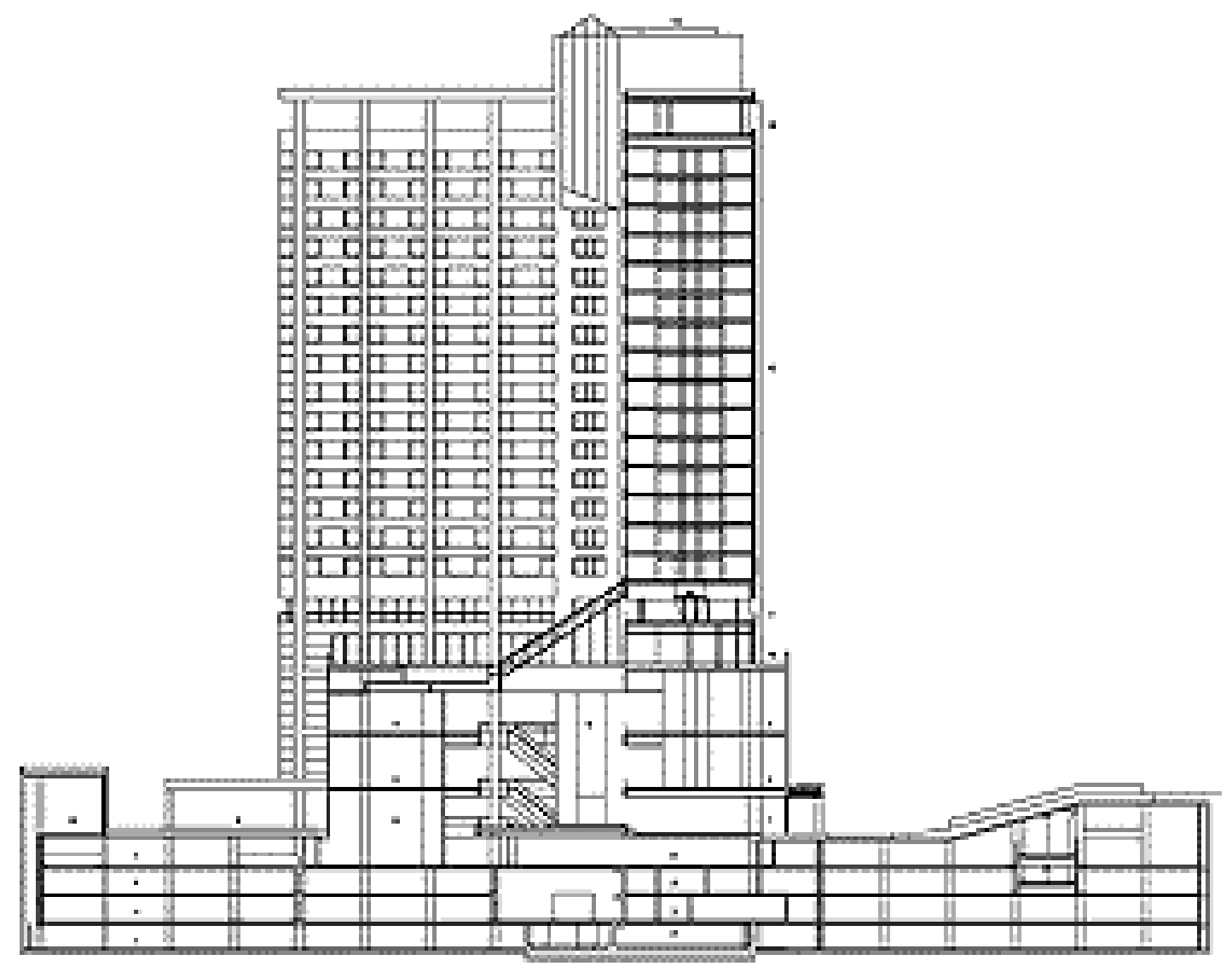

Fig. 25 WTC - SP Corte Transversal pela torre do Hotel Fonte: Revista AU no 60 jun/jul 95 
$1995 \Rightarrow$ Carlos Bratke entrega à Marginal Pinheiros, São Paulo, o edifício Plaza Centenário, que por suas formas arredondadas e por sua fachada totalmente em aluminio, recebe o apelido de "Robocop".

A torre possui $140 \mathrm{~m}$ de altura, 36 andares e segundo informações da empresa que montou os painéis da fachada, é o maior edifício do mundo com este tipo revestimento.

Ressaltando a funcionalidade da estrutura, os equipamentos são colocados em torres periféricas, para que o edifício possa contar com grandes vãos livres.

"A criação de um bloco único, organizado como corpo central, interceptado pelo cilindro da torre de serviços, onde estão concentrados os elevadores sociais, elevador de segurança para bombeiro, escada pressurizada". Em torno dessa torre foram dispostas outras quatro torres, circulares e menores, com sanitários e ar-condicionado.

O sistema operacional, que inclui automação e segurança integrada, está centralizado na sala de comando. Além de catracas para triagem de pessoal, o sistema dispõe de automação predial que inclui combate e prevenção de incêndio, como detectores de fumaça e alarmes. O edifício por ser todo revestido com placas de alumínio funciona como um gigantesco pára raios. Para isso as placas foram aterradas na ferragem da estrutura.

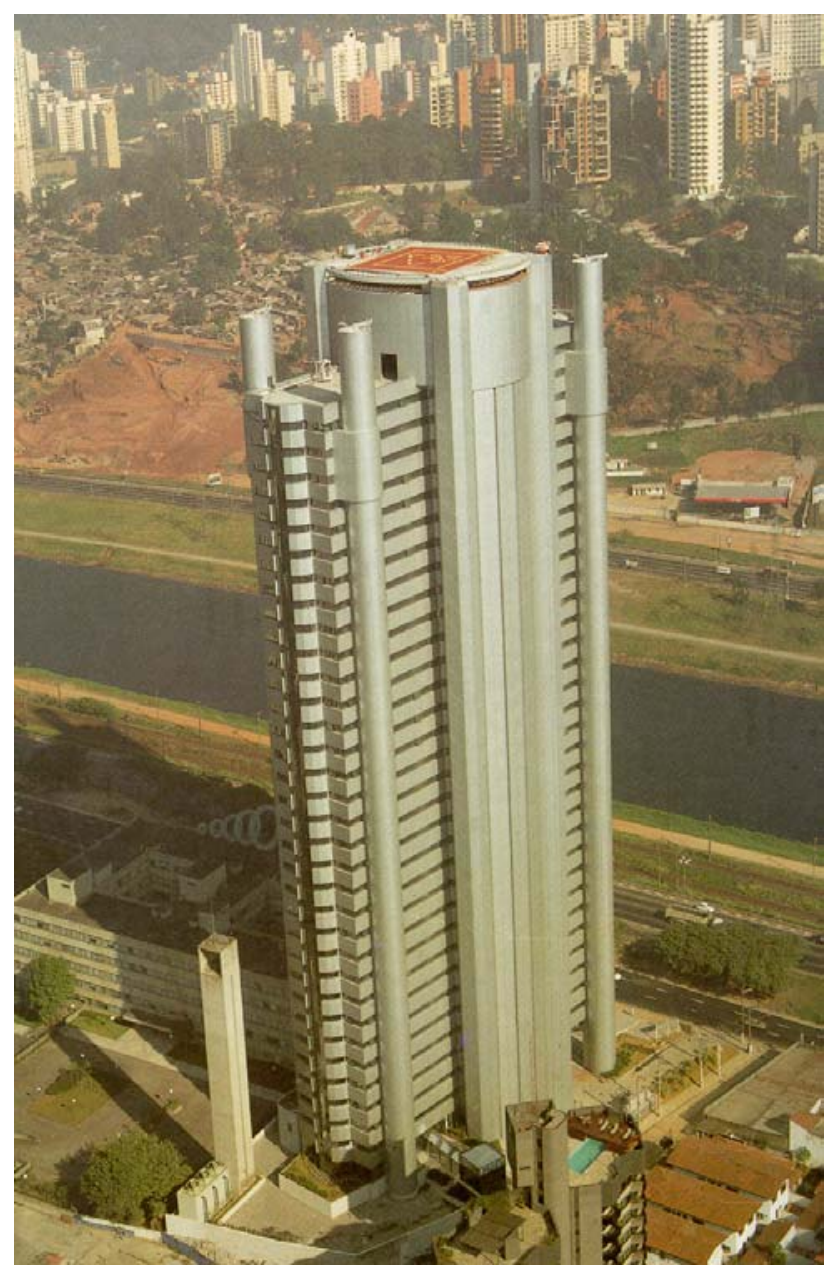

Fig. 26 Plaza Centenário - SP

Fonte: Revista AU no 61 ago/set 95 


\section{6 $\Rightarrow$ Edifício Bolsa de Imóveis do Estado de}

São Paulo, conhecido como Robocop II, projeto dos escritórios de Carlos Bratke e Renato Bianconi Arquitetos. Sua planta reflete certo refinamento das soluções desenvolvidas em outras obras por este escritório. Com salões livres de estruturas verticais, oferecendo grande flexibilidade para diversos tipos de layouts.

Neste caso, os pavimentos apóiam-se em torres periféricas, utilizadas para circulações verticais, tais como escadas de segurança, elevadores, monta-cargas e outros equipamentos sanitários, copas, depósitos, shafts para ar-condicionado e dutos em geral.

Fig. 27 Edifício Bolsa de Imóveis de SP

Fonte: Revista AU no 64 out/nov 96

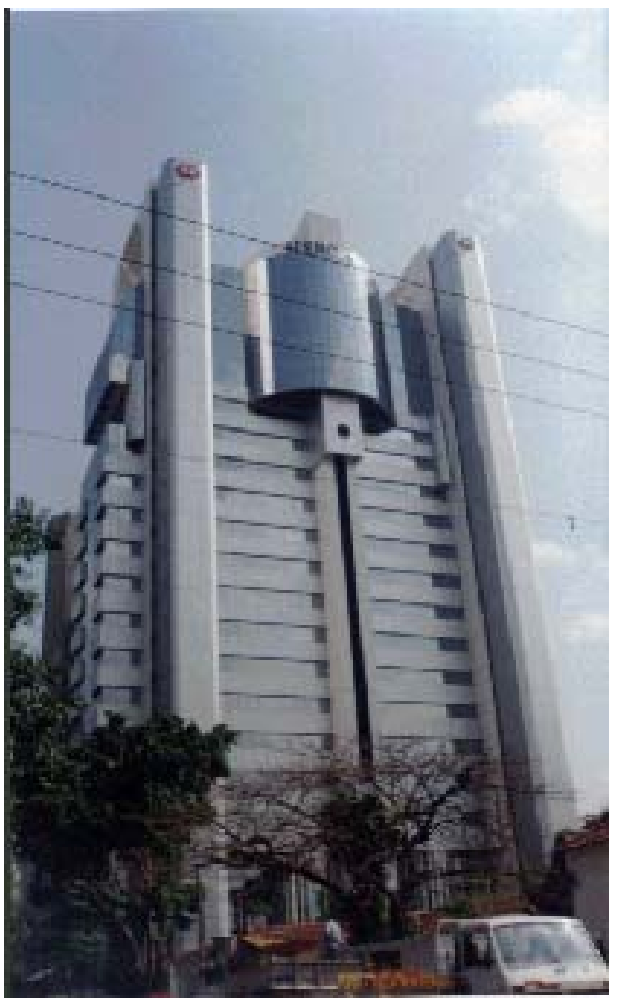

Os treze pavimentos-tipo são coroados por uma forma especial de

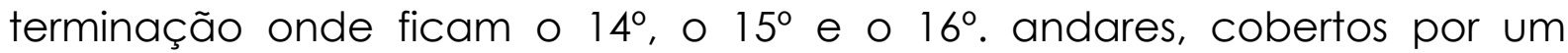
pergolado envidraçado, formando uma grande curva. Essa curva procura encaixar-se sob as outras curvas, formando meias abóbodas. São caixasd'água colocadas no topo das torres periféricas, encimando esses volumes, como se uma gerasse a outra. O acabamento do edifício foi executado com chapas autoportantes de alumínio, nas cores prata e branco. As chapas são facilmente moldáveis e dobráveis, podendo dessa maneira, adquirir características estruturais e se adaptar à volumetria da obra, acompanhando suas curvas, saliências e reentrâncias."

No que diz respeito a Edifício Inteligente pode-se dizer que este tem um dos Q.I. mais altos do país, pois foi bem projetado e executado, possui estrutura metálica, sistema automatizado, segurança $24 \mathrm{H}$, etc. Isto o deixa dentro dos padrões brasileiros de Edifícios Inteligentes (o padrão internacional é superior). São 19 andares, 4 subsolos completamente automatizados principalmente no quesito segurança, em relação a sinistros e à entrada de pessoas não autorizadas. Um carro tem acesso direto e coberto à recepção pela passagem de veículos, ou pode descer pela rampa (são duas de subida e uma de descida), para a garagem num dos quatro subsolos.

Na recepção o visitante é fotografado e recebe um crachá magnético. A catraca eletrônica só permite passagem até os setores onde ele foi liberado. O sistema de segurança possui câmeras de segurança em todos os locais estratégicos. O prédio é todo automatizado. Por exemplo, se alguém tentar fechar um registro hidráulico sem autorização, um sensor no registro acusa na central de segurança, que ele está sendo manuseado. Estes sensores estão espalhados por todo o prédio: no teto existem detectores de calor $e$ de fumaça (sprinklers), as portas de emergência acusam se forem abertas, 


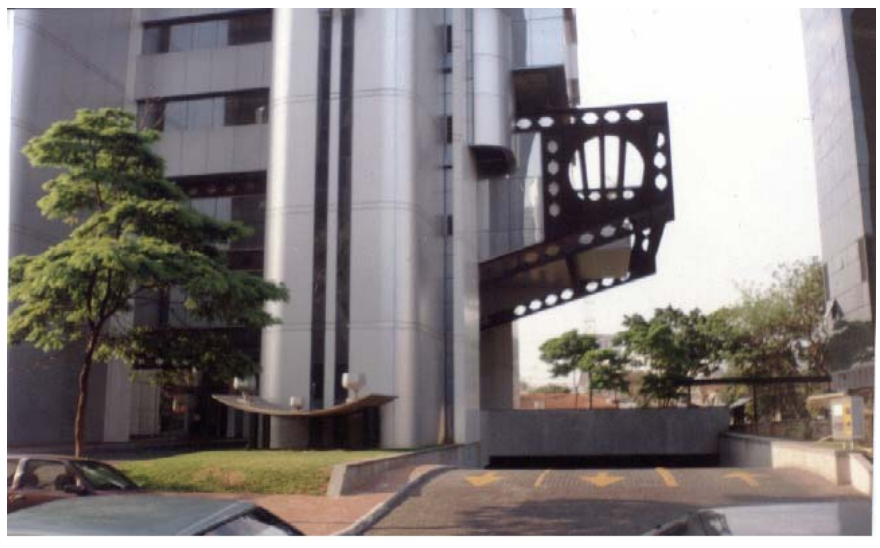

etc. A central de segurança fica no térreo e também cuida da parte de incêndio.

Fig. 28 Detalhe da entrada do Edifício Fonte: Revista AU no 64 out/nov 96

A circulação do edifício funciona do seguinte modo: possui duas escadas de emergências exclusivas por andar que atende a cada sala. Quem descer nessa escada só consegue sair no térreo. A porta somente abre por dentro e possui um sensor que acusa quando é aberta. E ainda existe a escada para uso geral com porta e paredes anti-chama e túnel de fumaça. São 6 elevadores para uso comum, um de carga e outro para uso exclusivo de pessoas vips.

No subsolo ficam: dois grandes geradores de emergência (que na falta de energia, entram em funcionamento tão rápido que esta transição nem é percebida, eles atendem ao prédio todo e possuem isolamento acústico), a central de distribuição de energia, o poço artesiano (que é ligado à rede de água comum e possui reservatório no topo do prédio e no subsolo), as vagas de carro com manobristas, a central de telefone e a central de ar condicionado.

O teto (forro) possui aproximadamente meio metro, para circulação elétrica e hidráulica(na área comum). O piso não é elevado mas possui pontos de energia. Na cobertura ficam a casa de máquinas do elevador, o reservatório d'água, os pára raios e as antenas.

Fig. 29 Maquete eletrônica do Edifício

Fig. 30 Planta do $2 \circ$ mesanino

Fonte: Revista AU no 64 out/nov 96
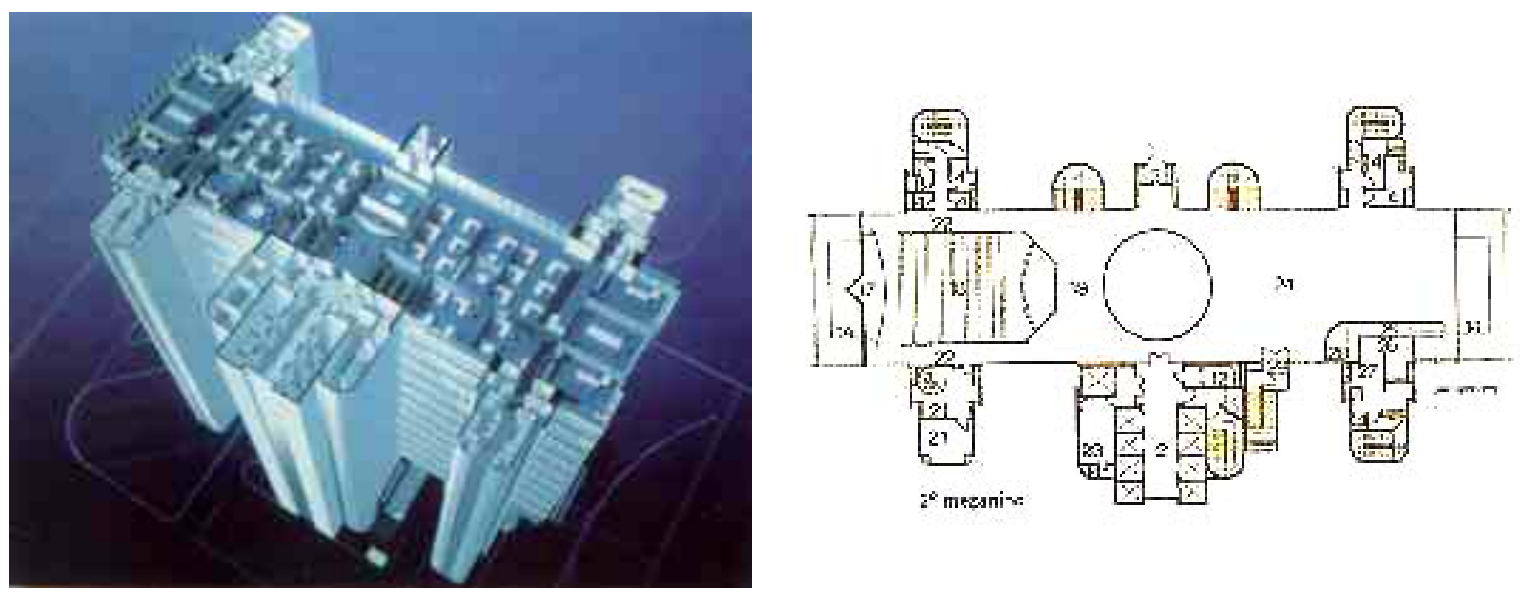

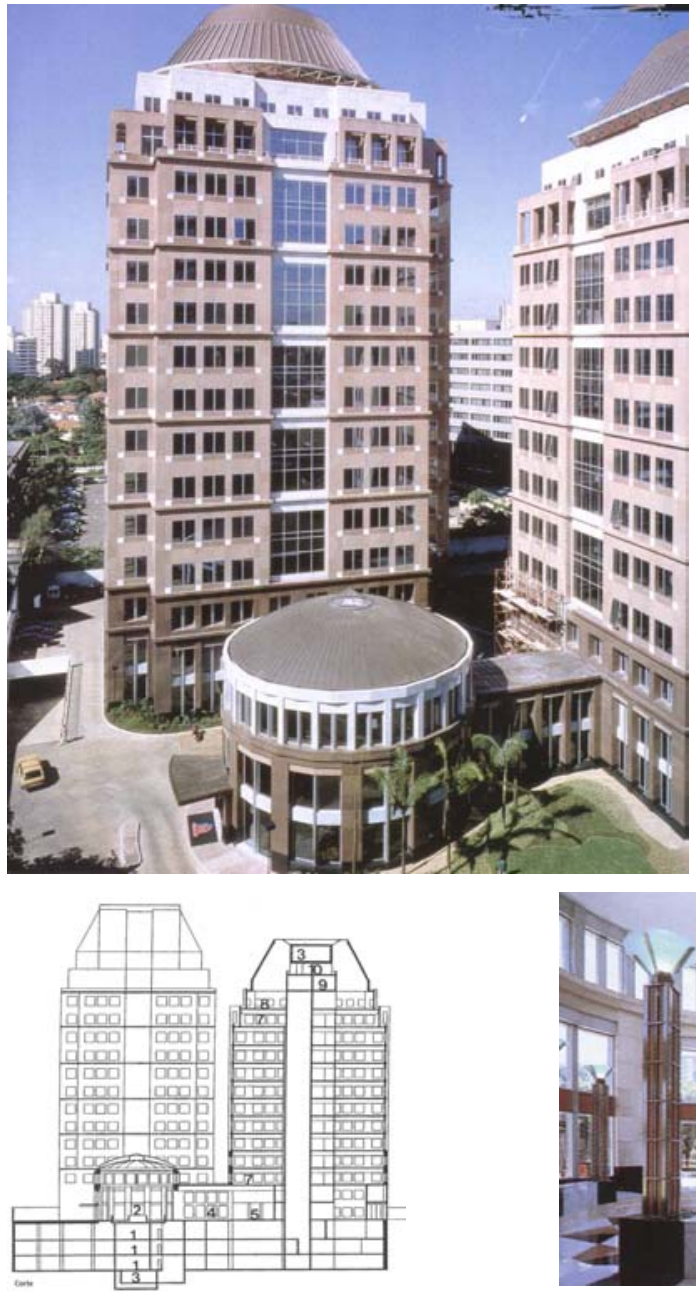

1996 $\Rightarrow$ Edifícios Birmann 11 e 12 Localizados na cidade de São Paulo, compõem um complexo comercial do tipo multiusuário com duas torres de doze e treze pavimentos. Projeto do Arquiteto Edson Musa.

Uma rotunda monumental dá acesso aos dois prédios e se interliga, através de elevadores com o estacionamento nos subsolos. Os edifícios foram projetados com volumes bem definidos, marcando a base, o corpo e cobertura com desenho especial.

Fig. 31 Edifícios Birmann 11 e 12 -SP

Fonte: Revista Projeto Design no 205 fev 97

Fig. 32 Corte Lateral do Complexo

Fig. 33 Hall de entrada de uma das torres

Fig. 34 Planta baixa do Complexo

Toda a estrutura das fachadas é revestida de granito e mármore com linhas verticais de perfis metálicos e vidro, que marcam o centro de cada fachada, dando profundidade e acentuando a verticalidade dos edifícios.

Um edifício de escritórios, embora a planta indique amplos salões aparentemente simples, é, na verdade, um projeto bastante complexo. Deve atender especificações técnicas que garantirão a flexibilidade de uso atual e futuro.

Alguns dos parâmetros presentes nos edifícios são: pisos com capaciade de carga alta que variam de 500 a $1000 \mathrm{~kg} / \mathrm{m}^{2}$, pé direito duplo, malha de piso com sistema de canaletas triplas para ligações de energia, telefone e lógica de fácil acesso em qualquer um dos andares, ar-condicionado com sistema de termoacumulação e elevadores de alta tecnologia.

O Sistema de automação predial é responsável pelo controle dos subsistemas de utilidades, totalizando aproximadamente 3200 pontos de controle e supervisão, entre os quais estão relacionados: ar condicionado, energia, hidráulica, iluminação e segurança patrimonial (Circuito Fechado de TV), detecção e alarme de incêndio e controles de acesso. 
1997 $\Rightarrow$ O Birmann 21 do escritório SOM - Skidmore, Owings \& Merrill e Kogan Arquitetos Associados, representa uma melhoria no padrão de qualidade de vida no escritório em um ambiente altamente motivacional e produtivo.

Seus $61.779 \mathrm{~m}^{2}$, dispõem de centro de conferência, restaurantes e cafeteria, health club, atendimento médico, loja de conveniências, sala central de correspondências e encomendas e praça de eventos.

O edifício de 26 pavimentos agrega múltiplas funções tais como: locais para conferências, cursos, espetáculos, escritórios, além de garagens.

O sistema estrutural foi concebido com a interação entre engenheiros e arquitetos, proporcionando assim a integração de sistemas mecânicos e elétricos, que regularmente precisam ser vistoriados e atualizados.

As tubulações de sprinklers passam por perfurações previstas nas vigas e a integração de pisos, forros, iluminação e ar-condicionado é feita entre vedos.

A central de controle do edifício tem a capacidade de monitorar pontos estratégicos e até corrigir pequenas falhas no sistema.

Em determinados andares praticamente só existe parede para contornar o edifício, o que traz grande a flexibilidade de layout.

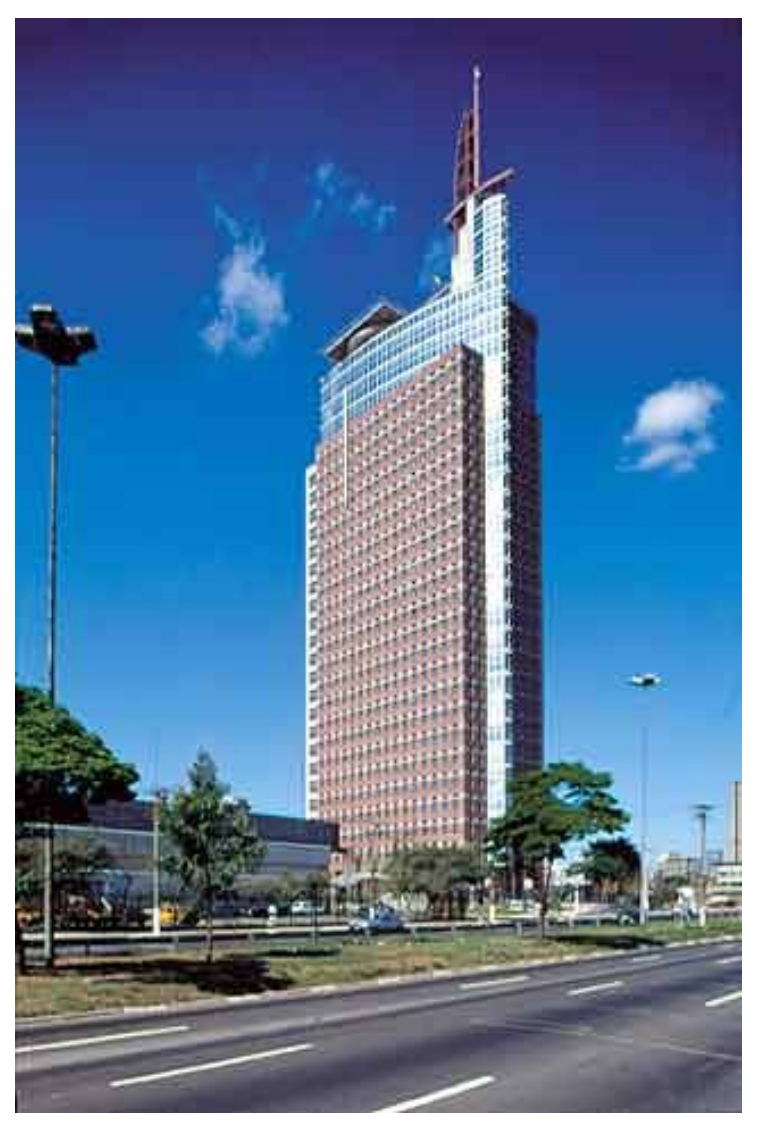

Fig. 35 Edifício Birmann 21 - SP

Fonte: Revista AU no 73 ago/set 97 
$1997 \Rightarrow$ O setor hoteleiro sofreu grandes transformações durante a década. Ativado pelo turismo, convenções e viagens a negócios, ele gerou uma série de empreendimentos: hotéis temáticos, hotéis de negócios, hotéis design, resorts ou pequenas pousadas. Um dado significativo foi o aumento, na década de 90, da participação das redes internacionais no país.

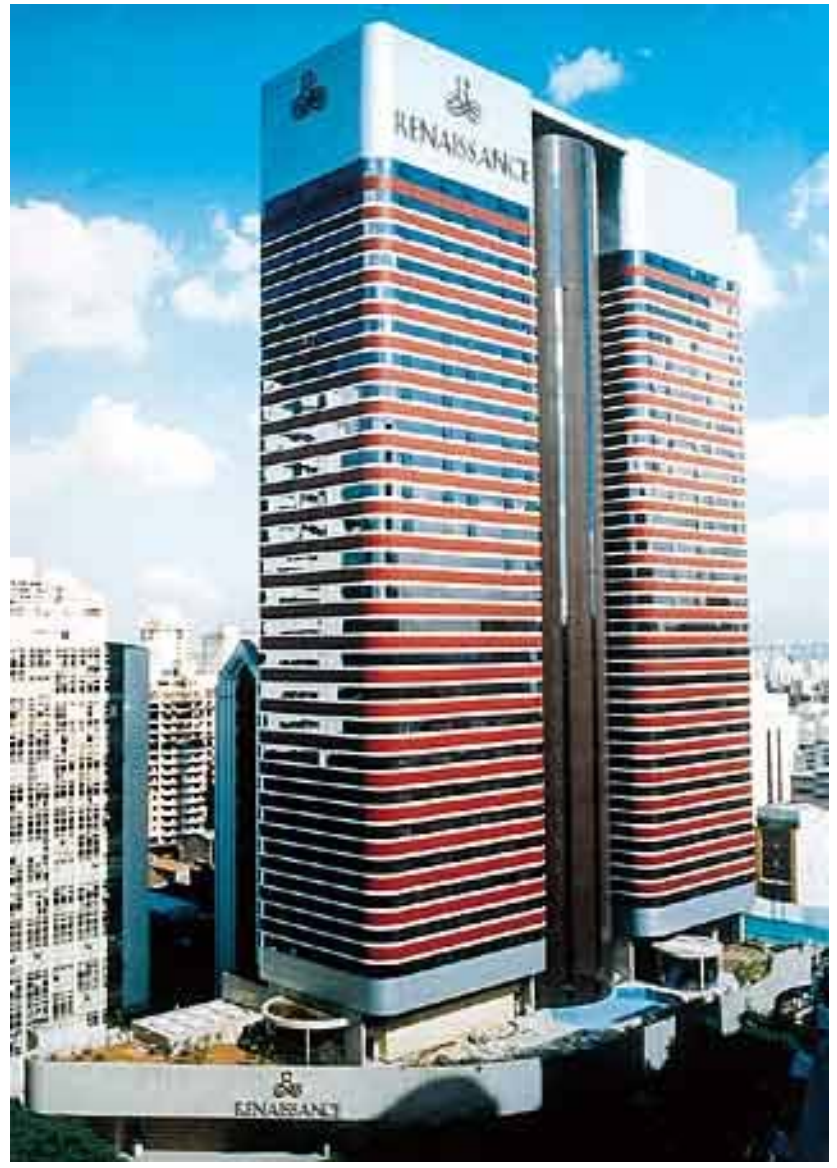

$1997 \Rightarrow \bigcirc$ Hotel Renaissance, que ocupa meia quadra na região da avenida Paulista em São Paulo, é um claro exemplo desse interesse estrangeiro.

Com 450 apartamentos, investimento de 100 milhões de dólares e projeto de Ruy Ohtake, o empreendimento é dividido em dois volumes. A torre de 27 andares, revestida de alumínio vinho e prata, destaca-se com sua elegância no desordenado entorno; o embasamento recebeu - concreto característico do trabalho do arquiteto.

Fig. 36 Hotel Renaissance - SP

Fonte: Revista AU no 72 jun/jul 97

O Renaissance é um catálogo de novidades em computação. Logo no hall de entrada, as cortinas que cobrem as paredes envidraçadas sobem e descem sob comando de um controle remoto. Ao lado da recepção, um painel eletrônico de 2 metros de altura mostra horário e descrição dos eventos programados para o dia. No bar, os garçons fazem os pedidos diretamente numa tela de computador sensível ao toque. Basta encostar o dedo sobre o item determinado e pronto, está feito o pedido. A despesa é enviada eletronicamente para a conta do hóspede, junto com seu consumo de frigobar, ligações telefônicas, e serviços de quarto.

No bar-dançante, hóspedes e visitantes fazem seus pedidos a garçons equipados com computadores de mão conectados à cozinha e ao sistema de contabilidade.

Fig. 37 Mapa de Localização Fonte: Revista AU no 72 jun/jul 97

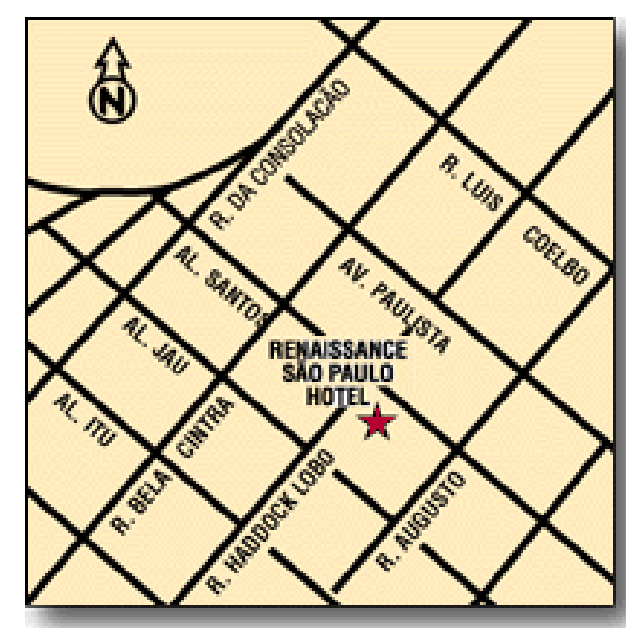


Em cada quarto, há sensores de temperatura e de movimento. Assim que o hóspede encaixa o cartão com tarja magnética na fechadura eletrônica de seu quarto, a central computadorizada ordena que se acendam as luzes da cabeceira, do banheiro e o ar-condicionado.

Conta ainda com pontos de transmissão de voz e dados nos quartos, conectados à Internet.

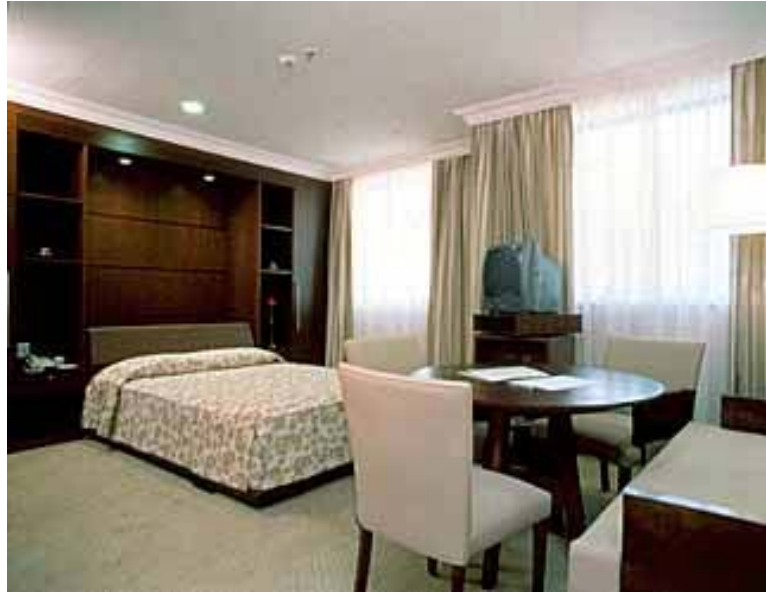

Fonte: Arquivo Pessoal

Fig. 39 Depois... - local de trabalho

Toda as informações e preferências dos hóspedes são armazenadas numa rede central projetada para não ter paradas.

Fig. 38 Antes - Quarto
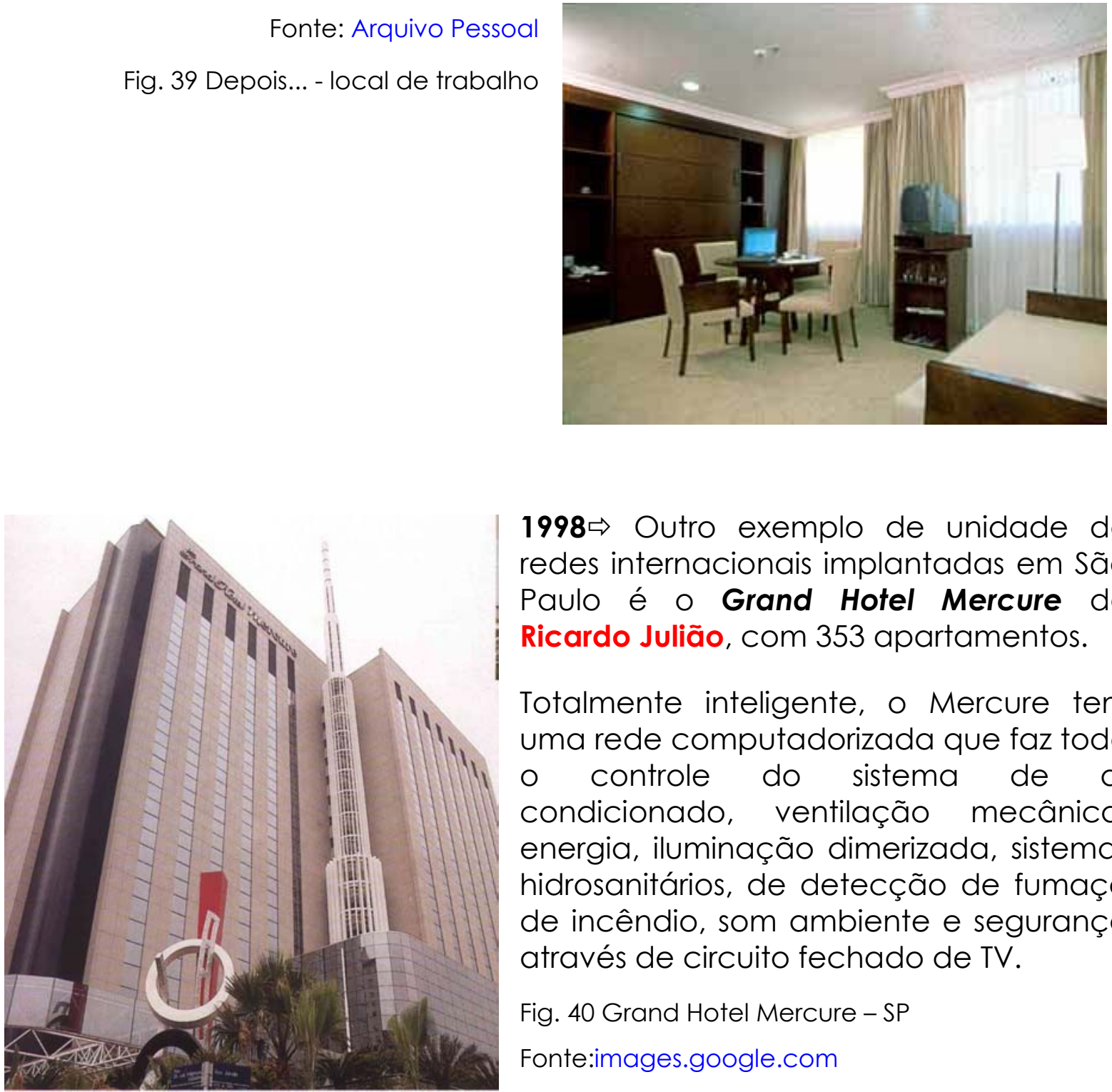

1998 $\Rightarrow$ Outro exemplo de unidade de redes internacionais implantadas em São Paulo é o Grand Hotel Mercure de Ricardo Julião, com 353 apartamentos.

Totalmente inteligente, o Mercure tem uma rede computadorizada que faz todo - controle do sistema de ar condicionado, ventilação mecânica, energia, iluminação dimerizada, sistemas hidrosanitários, de detecção de fumaça de incêndio, som ambiente e segurança através de circuito fechado de TV.

Fig. 40 Grand Hotel Mercure - SP

Fonte:images.google.com 
1998 $\Rightarrow$ Projeto dos arquitetos Marc Rubin e Alberto Botti, o Centro Empresarial Nações Unidas, inaugura a torre Oeste, a primeira de três torres que fazem parte do complexo.

O conjunto insere-se em uma lista de 39 edifícios com classificação AA (alta tecnologia), de acordo com um levantamento da Bolsa de Imóveis de São Paulo.

Três torres de escritórios somando 83 andares, 2 Centros de Convenções e o Shopping Nações Unidas, compõem um conjunto harmonioso de $304.534 \mathrm{~m}^{2}$, rigorosamente planejados dentro dos mais avançados tecnológicos de conceitos engenharia e administração predial.

Fig. 41 Centro Empresarial Nações Unidas - SP maquete eletrônica

Fonte:http://www.imovelweb.com.br

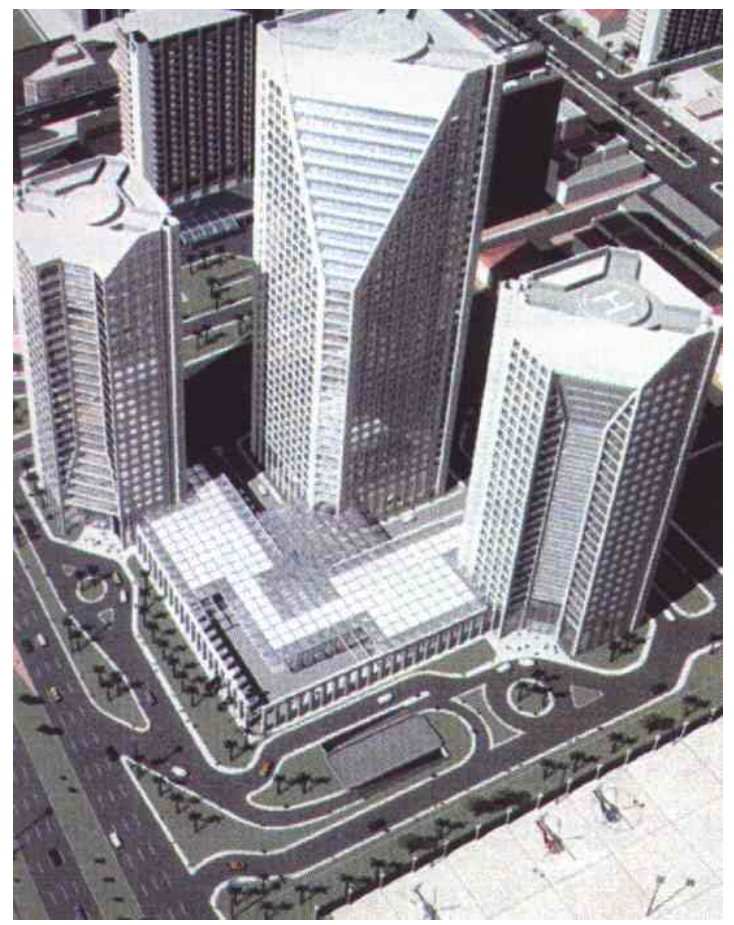

No subsolo do CENU, interligando as três torres, está o Shopping Center Nações Unidas que possui aproximadamente $3.048 \mathrm{~m}^{2}$, contendo diversos restaurantes, cafés, papelaria, farmácia, bancos entre outros serviços. O Shopping está ligado ao Complexo World Trade Center através de um amplo corredor subterrâneo para pedestres. Este complexo abriga o Hotel Gran Meliá, o Shopping D\&D, um centro de convenções e uma torre de escritórios.

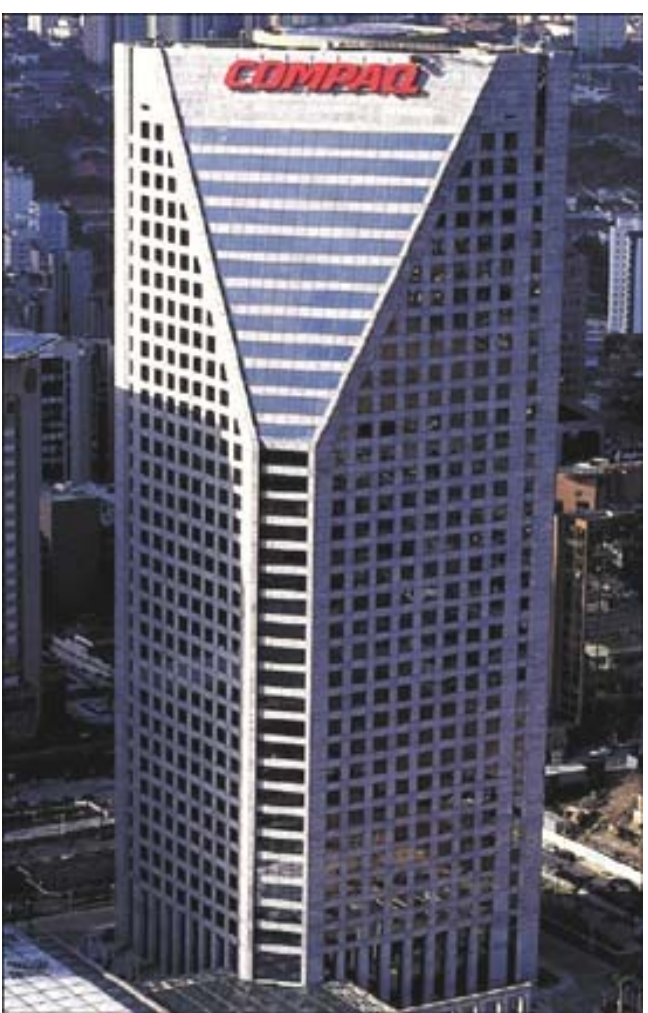

O CENU é hoje considerado um empreendimento de referência na região por causa do seu porte, localização e visibilidade.

1999 $\Rightarrow$ Inaugurada em novembro de 1999, a Torre Norte do Centro Empresarial Nações Unidas (CENU), construída pela Tishman Speyer-Método.

A Torre Norte é um dos maiores e mais modernos edifícios de escritórios da América do Sul. É a torre central do Centro Empresarial Nações Unidas (CENU), que é composto por três torres e um shopping center.

Fig. 42 CENU - SP Torre Norte

Fonte: Revista AU no 37 ago/set 91 
A Torre Norte é composta por 34 andares de escritórios, 2 andares mecânicos, térreo com pé-direito duplo, 2 mezaninos e 5 subsolos, além de um heliponto. A altura da torre é de 158 metros e a área construída total, acima do nível térreo, é de $68.096 \mathrm{~m}^{2}$.

Das 3.734 vagas de garagem do CENU, 1.954 vagas estão alocadas à Torre Norte, resultando em 1 vaga para cada $28.6 \mathrm{~m}^{2}$ de área privativa. Além da área de escritórios, o imóvel possui um "Business Center" com capacidade para eventos de até 300 pessoas.

2000 $\Rightarrow$ Começam as obras de construção da terceira torre do Centro Empresarial Nações Unidas, a torre Leste. Da mesma altura da torre Oeste com 138m, foi inicialmente projetada para ser uma torre de escritórios, mas agora está sendo desenvolvida para comportar o Hotel Hilton, com 506 apartamentos.

Fig. 43 CENU - SP Fundação Torre Leste Fonte: Revista Téchne maio/jun 1999 no 40

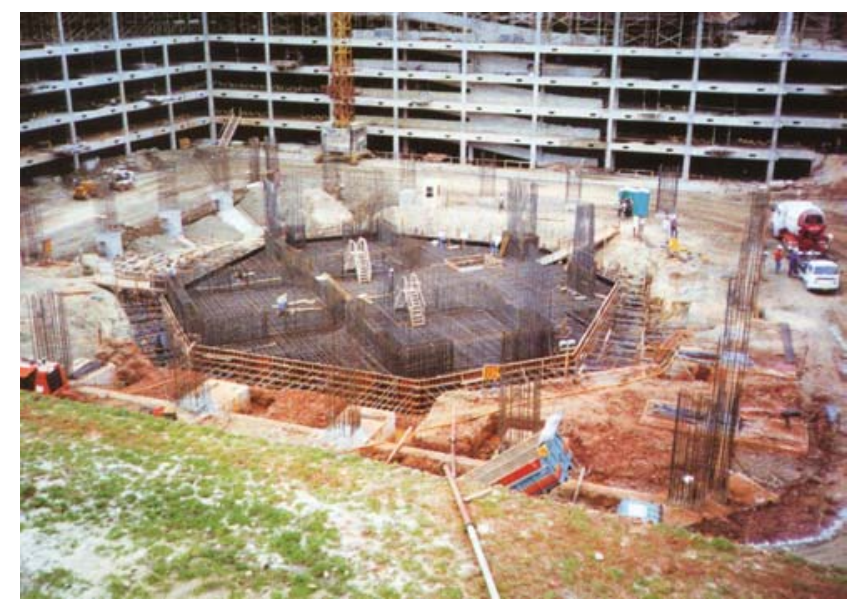

2001 $\Rightarrow$ A solução arquitetônica para esse complexo hoteleiro, foi encontrada pelo arquiteto Roberto Candusso na forma da letra "Y", dividindo o conjunto em três asas. Isto possibilitou encurtar corredores, reduzir a circulação e dispor as unidades de forma que uma não devassasse a outra. Reúne em um mesmo espaço um hotel cinco estrelas Caesar Park, um quatro estrelas Caesar Business, um centro de convenção para mil pessoas, restaurantes, salas de reunião, lojas, dois business centers e ampla área de lazer,

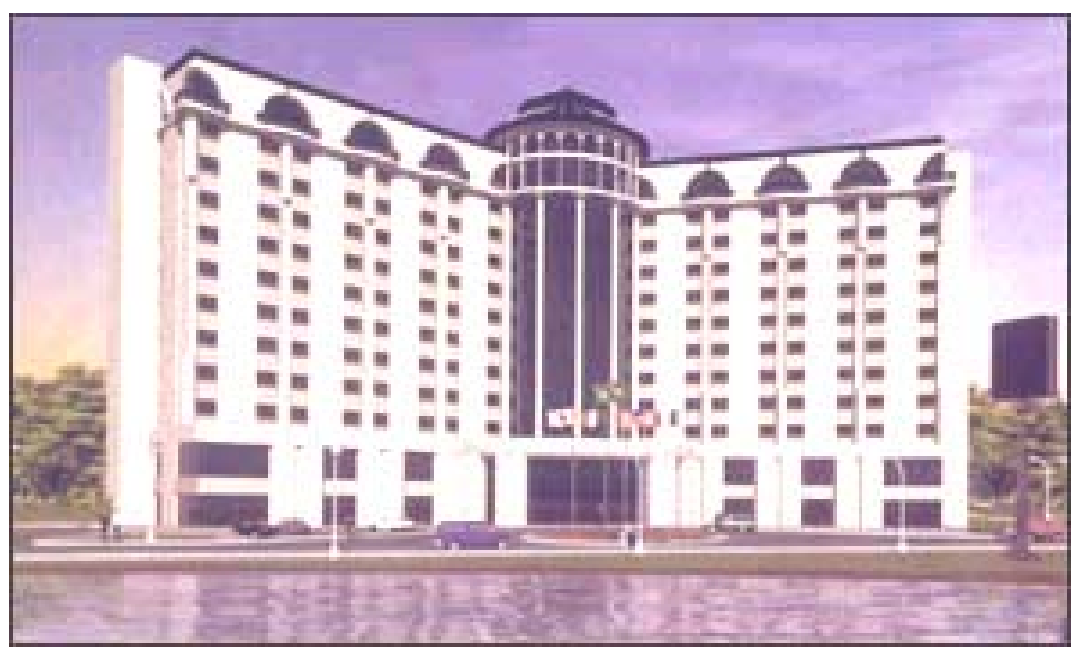
distribuídos em 13 pisos que ocupam área total de 33 mil m².

Fig. 44 Caesar Park e Caesar Business - SP

Fonte: http://www.qualyconstrutora.com.br/inf2.html 
2002 $\Rightarrow$ Localizado entre as avenidas Chucri Zaidan e Nações Unidas, o novo edifício do Bank Boston, foi concebido pelos escritórios norte-americanos Som e ETJN e adaptado por projetistas brasileiros.

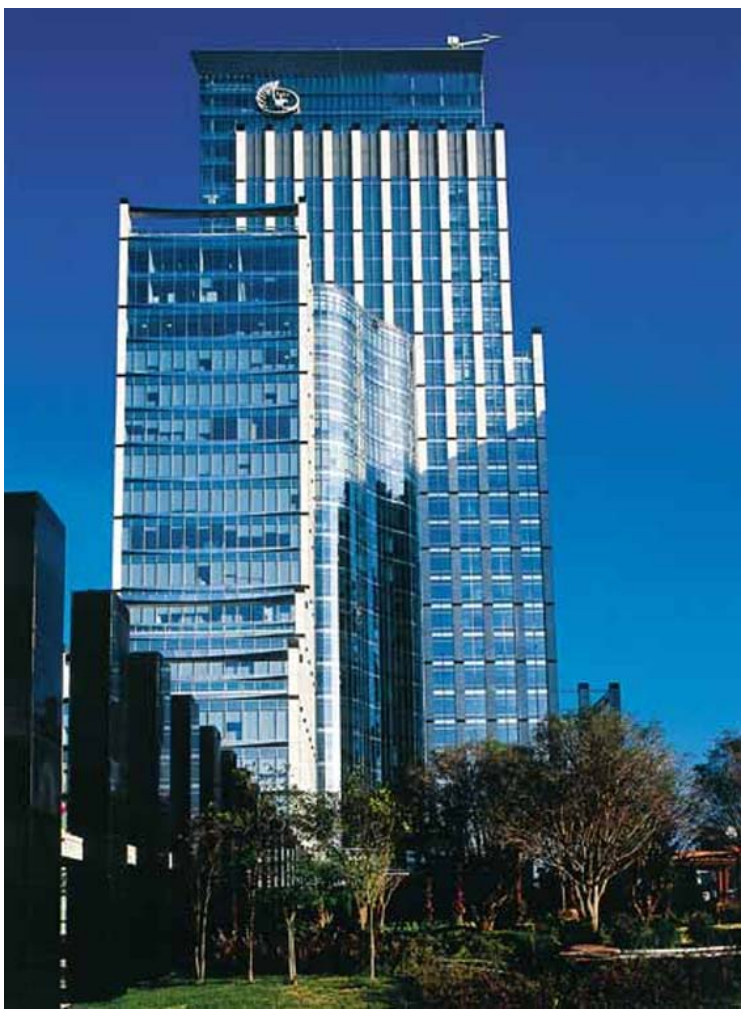

A obra, iniciada em meados de 1999, precisou de muito planejamento e logística para garantir equipes, materiais e equipamentos em todas as frentes. Para atender ao padrão de qualidade e às exigências do Bank Boston, a construtora providenciou ferramentas especiais, conformou no próprio canteiro os perfis de alumínio da fachada, superdimensionou os geradores de energia e adotou diversas outras medidas estratégicas. Foram obedecidas normas bastante rígidas de segurança do trabalho e de contratação de subempreiteiros, de forma que cada engenheiro fosse responsável por uma etapa de serviço.

Fig. 45 Bank Boston - SP

Fonte: Revista Téchne fev 2002 n० 59

O Bank Boston investiu na aquisição de uma câmara de ensaios de protótipos de fachadas-cortina, que permitiu realizar ensaios de pressão, positiva ou negativa, para cargas uniformemente distribuídas, de até $5.000 \mathrm{~Pa}$ (cerca de $506 \mathrm{~kg} / \mathrm{m}^{2}$ - o equivalente a ventos com velocidade de $324 \mathrm{~km} / \mathrm{h}$ ).

Fig. 46 Câmara de Ensaios Fonte: Revista Téchne fev 2002 no 59 Como a estrutura possui um vão atípico de $21 \mathrm{~m}$, o projeto concebeu vigas protendidas de $80 \mathrm{~cm}$ de largura com $75 \mathrm{~cm}$ de altura e lajes armadas. Para compor a fachada, a distância entre os pilares é sempre a mesma. Os pórticos periféricos, compostos por pilares e vigas, pouco contribuem para o contraventamento da estrutura, em função dos grandes vãos. $O$ enrijecimento

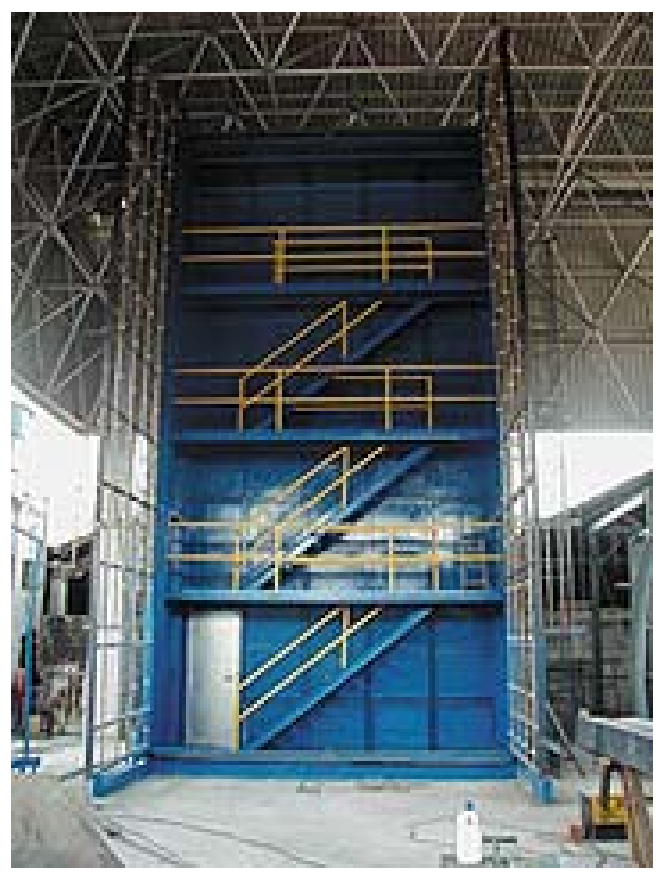
da obra é garantido por um núcleo central, dividido em duas asas em 'L' até - 190 andar, que a partir daí fica mais esbelto. Por causa do núcleo de rigidez, a movimentação horizontal no topo do edifício, nas piores ocorrências de vento, fica reduzida para apenas $10 \mathrm{~cm}$.

O condicionamento central, com reservatório de água gelada, atende ao prédio no horário normal de funcionamento. São 14 condicionadores 
distribuídos em pavimentos técnicos que conduzem o ar por três grandes prumadas. A distribuição de ar com sistema VAV (volume de ar variável), na temperatura de $8^{\circ} \mathrm{C}$, reduz a vazão necessária para o condicionamento. Nos pavimentos o ar é distribuído por dutos horizontais localizados no plenum sobre o forro rebaixado. Somente na cozinha o ar é exaurido pelas coifas. $O$ retorno do ar é centralizado em dois shafts verticais que interligam as casas de máquinas.

A concentração das máquinas em pavimentos técnicos assegurou uma manutenção mais rápida e menos onerosa. O sistema de filtragem do ar passa por três estágios: filtro grosso G3, fino Fl e de carvão ativado. Este último elimina o odor de gases atmosféricos provenientes do Rio Pinheiros.Os três geradores a diesel existentes são capazes de suprir toda a energia consumida no edifício, inclusive pelo sistema de ar-condicionado e são acionados no horário de pico, quando a energia da concessionária fica mais cara-das 17:30h às 20:30h.

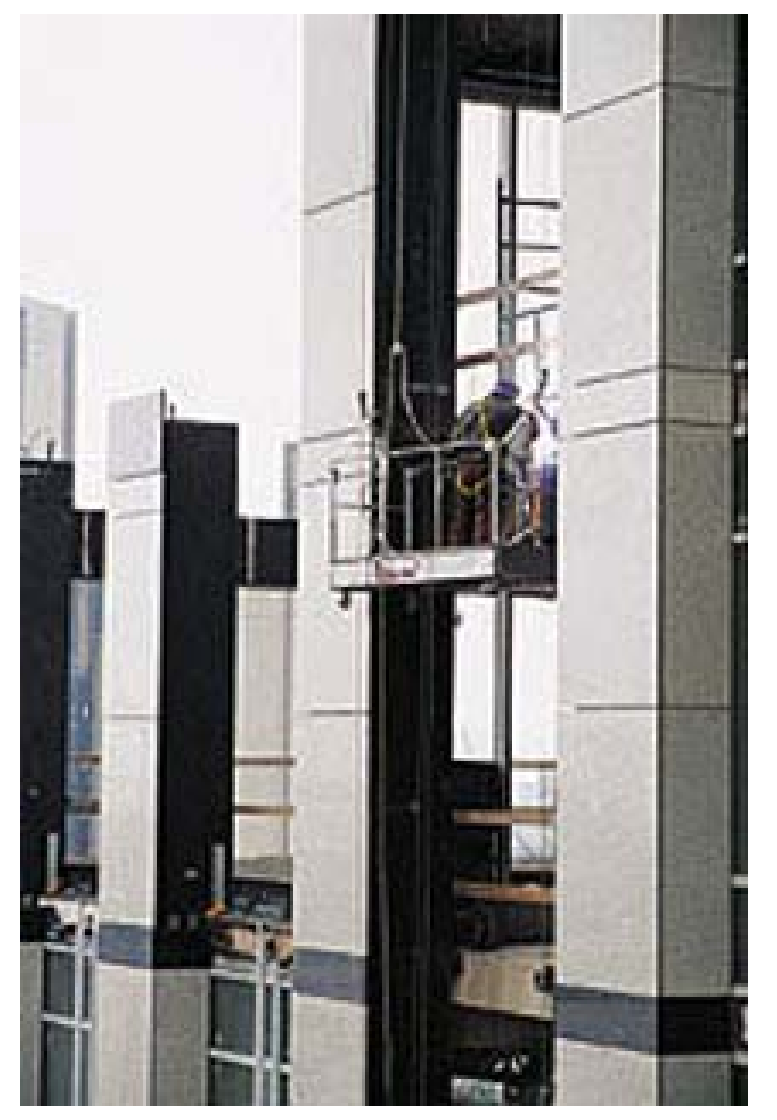

O sistema da fachada, que se estende por 22 mil $\mathrm{m}^{2}$, é unitizado. Dessa maneira, os painéis de fachada são içados por um guindaste já com os vidros, e $O$ isolamento térmico e acústico colocados. Os painéis vão de laje a laje, possuem altura de $4,30 \mathrm{~m} \mathrm{e}$ foram dimensionados para suportar os tufões americanos. As placas de vidro que compõem os painéis unitizados possuem a tecnologia low-e (baixa emissividade), que barra a entrada de uma considerável carga térmica sem reduzir a transmissão luminosa. Porém, como a insolação excessiva poderia prejudicar o conforto visual dos ocupantes, foi colocada uma tela de sombreamento que permite entrar somente a claridade necessária.

Fig. 47 Painéis das fachadas- SP

Fonte: Revista Téchne fev 2002 no 59

O cliente optou por materiais nacionais, já que o Brasil possui mais de 300 tipos de rochas. O granito "Branco Ceará" e o "Preto São Marcos", provenientes respectivamente do Ceará e da Paraíba, foram escolhidos para a fachada. O sistema metálico de fixação utilizado é o mais moderno em termos de segurança, desempenho e durabilidade, além de formar um colchão de ar atrás das placas, o que contribuiu para o conforto ambiental do edifício.Para combater o ruído médio de $65 \mathrm{~dB}$ na cidade de São Paulo, utilizou-se lã de rocha, que evita a passagem de som entre os andares, isolando-se acusticamente a estrutura e os elementos das fachadas. $\mathrm{Na}$ caixilharia foram empregados vidros duplos, com câmara de vácuo interna. 
As três máquinas de ar-condicionado, de 1,6 MW (454,5 TR), receberam tratamento acústico. A colocação de alto-falantes nos forros proporciona uma sonorização mais uniforme nos andares.

Fig. 48 Bank Boston - SP

Fonte: Revista Téchne fev 2002 n० 59

No restaurante, para causar a sensação de se estar fora do prédio, foi explorada a fachada de vidro. O layout estará em constante mudança. Em uma das paredes, está sendo montado um painel de azulejos pintados pelos filhos dos funcionários do banco. O restaurante também poderá ser usado como um segundo auditório, com instalações elétricas projetadas para esse fim e mesas empilháveis.
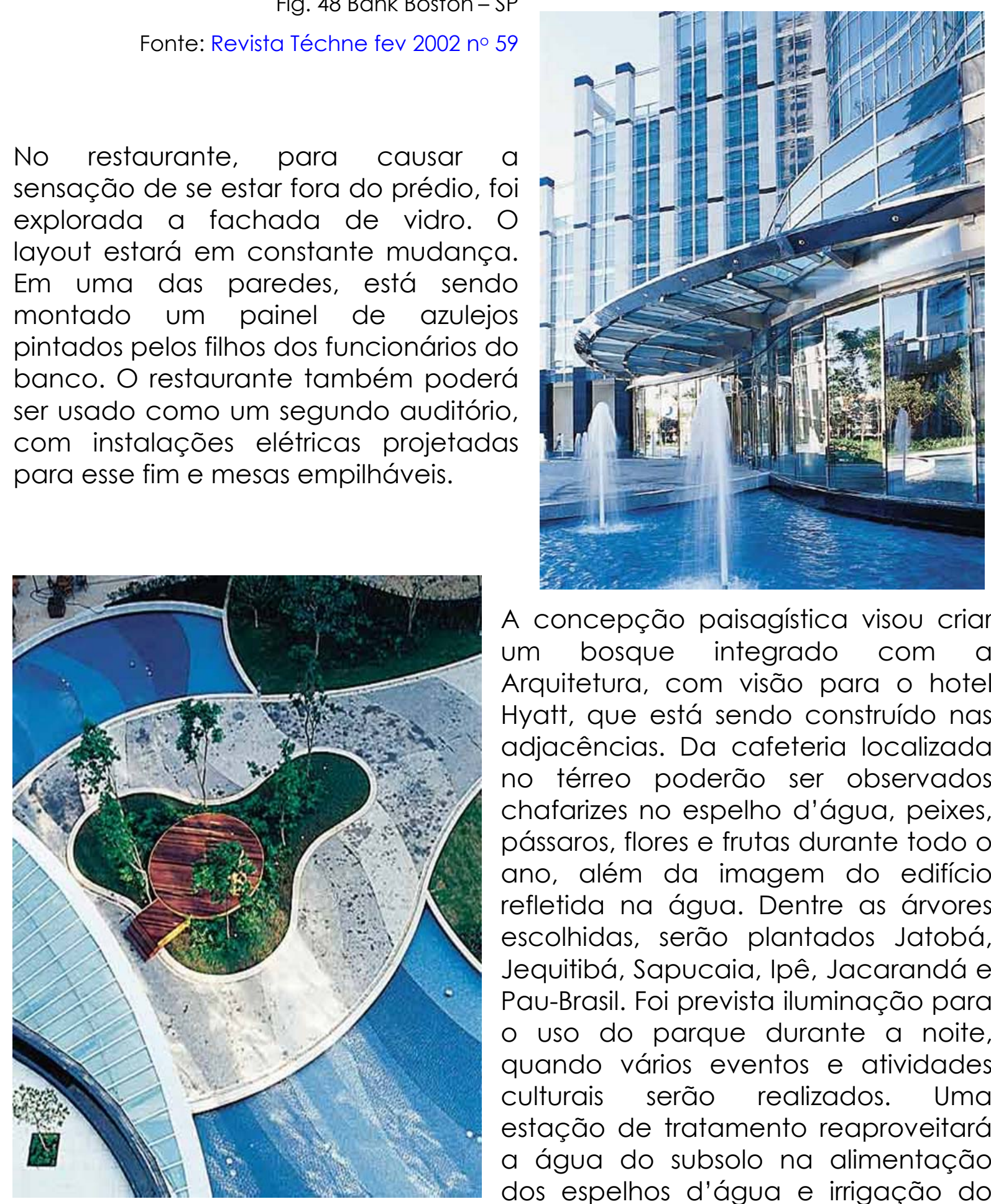

A concepção paisagística visou criar um bosque integrado com a Arquitetura, com visão para o hotel Hyatt, que está sendo construído nas adjacências. Da cafeteria localizada no térreo poderão ser observados chafarizes no espelho d'água, peixes, pássaros, flores e frutas durante todo o ano, além da imagem do edifício refletida na água. Dentre as árvores escolhidas, serão plantados Jatobá, Jequitibá, Sapucaia, Ipê, Jacarandá e Pau-Brasil. Foi prevista iluminação para - uso do parque durante a noite, quando vários eventos e atividades culturais serão realizados. Uma estação de tratamento reaproveitará a água do subsolo na alimentação dos espelhos d'água e irrigação do jardim.

Fig. 49 Paisagismo - espelho d’água e árvores brasileiras

Fonte: Revista Téchne fev 2002 no 59 


\subsection{Conceitos Utilizados}

Nossa apresentação conceitual expõe algumas definições, objetivando criar uma forma mais clara e sistematizada de comunicação com os leitores desta dissertação. Evitamos assim um texto excessivamente abstrato e mesmo literário, pois julgamos ainda não ser o caso da elaboração de uma teoria do Edifício Inteligente e também por ser inevitável para compreensão da terminologia empregada.

Iniciaremos esta breve síntese através do entendimento de que os conceitos de Telemática, automação, birótica, entre outros termos, estão relacionados diretamente com a área de edifícios de alta tecnologia.

1. EDIFÍCIO INTELIGENTE ou SMART BUILDING relacionamos alguns dos conceitos utilizados para definir estas expressões:

- $|B|$ - Intelligent Buildings Institute, define como: "aqueles que oferecem um ambiente produtivo e econômico através da otimização de quatro elementos básicos: Estrutura, Sistemas, Serviços e Gerenciamento; bem como das inter-relações entre eles".

- "Edifício Inteligente é aquele que incorpora dispositivos de controle automático aos seus sistemas técnicos e administrativos". (FRAZATTO, 2000)

- "O Edifício Inteligente é aquele que conjuga, de forma racional e econômica, os recursos técnicos e tecnológicos disponíveis de forma a proporcionar um meio ideal ao desenvolvimento de uma atividade humana".

- "Edifício é aquele que responde às necessidades de seus usuários, quão variadas sejam, e que conserva a capacidade de evoluir, incorporando a qualquer tempo, os recursos tecnológicos que venham a ser convenientes".

2. TELEMÁTICA é a convergência das tecnologias de telecomunicações, informática e mídias que dará suporte às funções de automação do edifício.

Fig. 50 Gráfico de convergência das tecnologias de Telemática, Telecomunicações e mídias

Fonte: Arquivo pessoal

De acordo com a função desempenhada pela edificação que abriga as novas tecnologias da Telemática, podemos subdividir em duas:

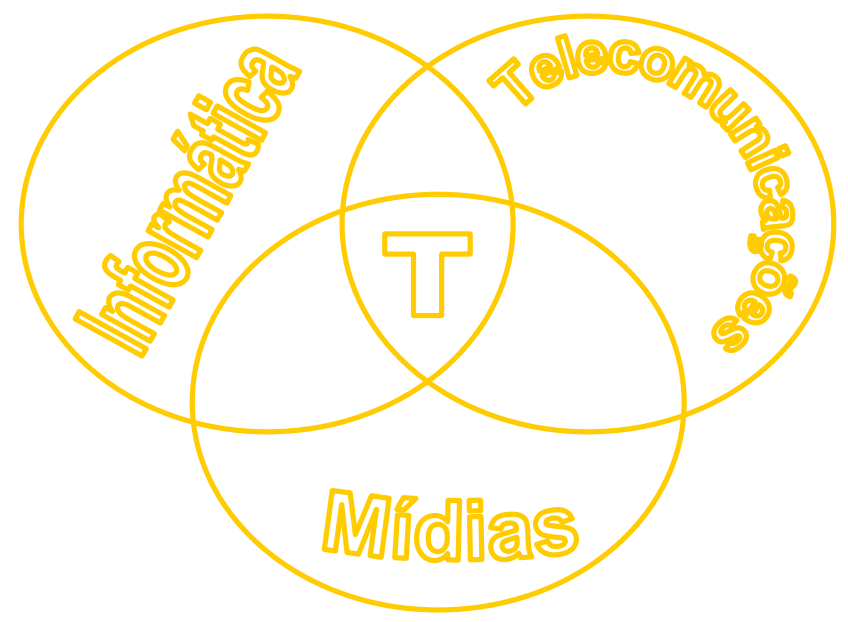


Birótica: é o emprego da automação dentro do escritório, onde os usuários poderão ter acesso a qualquer tipo de informação, criando um modelo de trabalho corporativo.
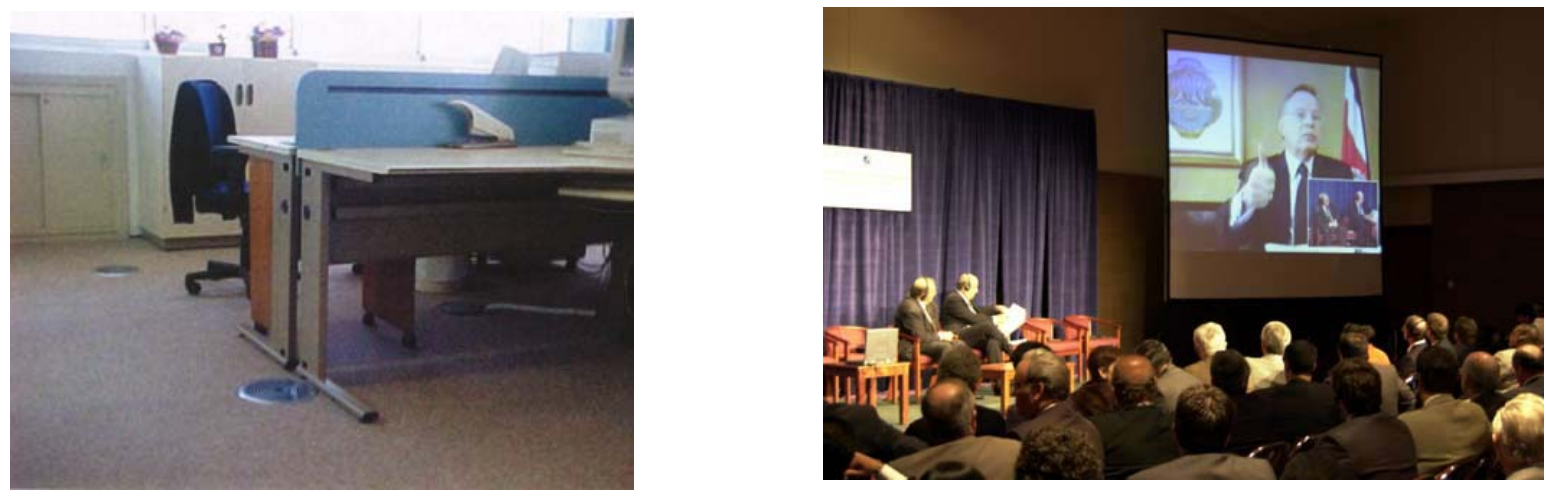

Fig. 51 Edifício com insuflamento de ar pelo piso

Fig. 52 Edifício com sistema de teleconferência Fonte: http://images.google.com

Domótica: a palavra domótica se refere à ciência e aos elementos desenvolvidos por ela, que proporcionam algum nível de automação dentro da casa, desde um simples temporizador (timer) para acender e apagar uma lâmpada em uma determinada hora, até os mais completos sistemas capazes de controlar qualquer elemento elétrico dentro da residência.

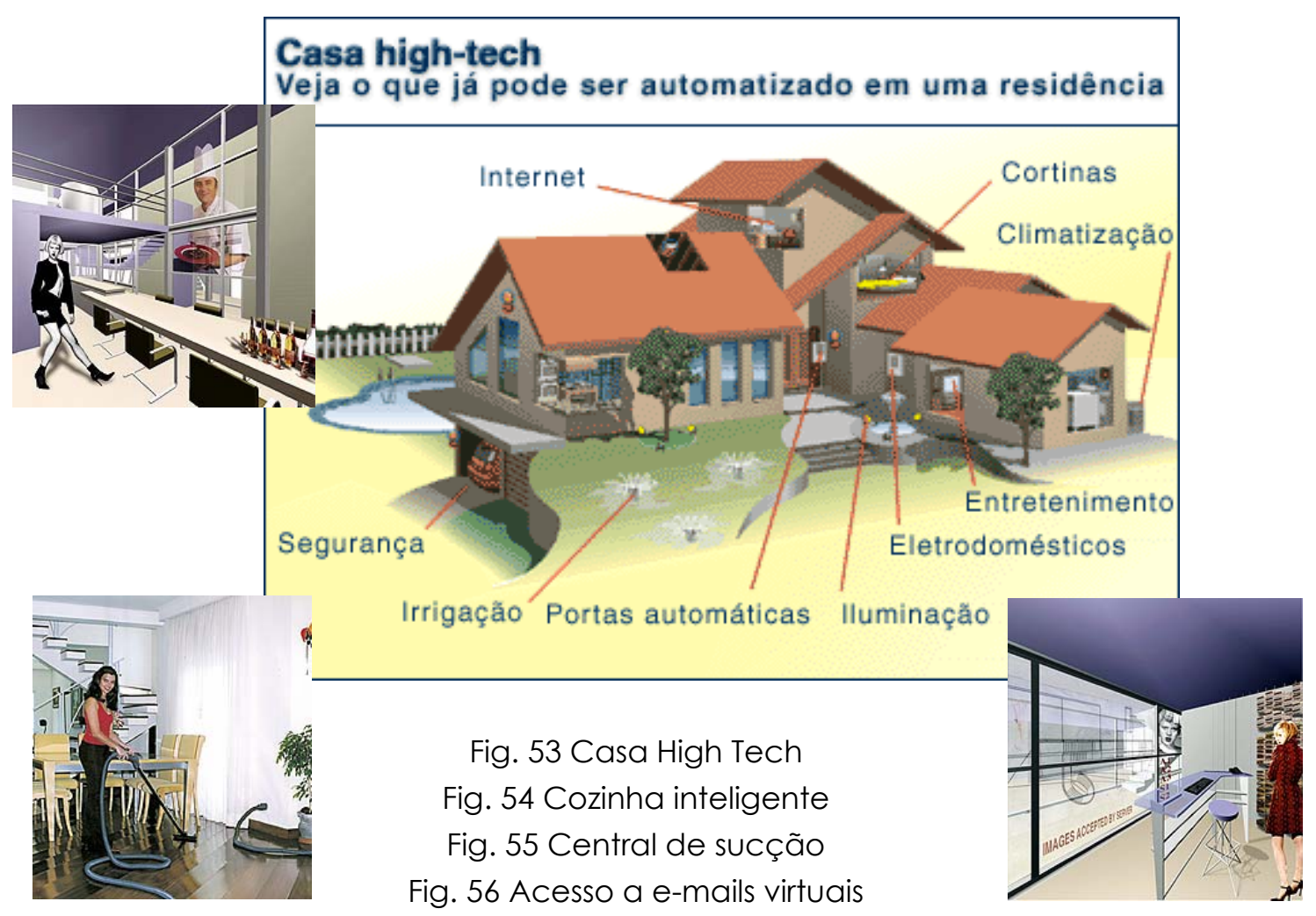

Fonte: http://images.google.com 


\section{REDES ELETRÔNICAS - CARACTERIZAÇÃO}

As redes podem caracterizar-se quanto à sua dispersão geográfica em três tipos principais. São eles: LAN, MAN e WAN.

LAN: local area network. É o nome que se dá a uma rede de caráter local, e onde estão ligados alguns sistemas numa área geográfica pequena. Normalmente uma LAN está enquadrada num escritório ou numa empresa não dispersa geograficamente. As tecnologias principais que uma LAN pode utilizar são a Ethernet, o Token Ring, o ARCNET e o FDDI ("Fiber Distributed Data Interface").

MAN: Metropolitan area network. Esta rede de carácter metropolitano liga computadores e utilizadores numa área geográfica maior que a abrangida pela LAN, mas menor que a área abrangida pela WAN. Uma MAN normalmente resulta da interligação de várias LAN numa cidade, formando assim uma rede de maior porte, podendo inclusive estar ligada a uma rede WAN. O termo MAN é também usado para referir a ligação de várias redes locais por bridges (este procedimento pode ser denominado de bridging). Por vezes este tipo de MAN é referida por campus network. Existem várias cidades que possuem redes metropolitanas de vários tamanhos como Londres, Lodz, Genebra, etc. CRESPO (1999).

WAN: Wide area network. Como o nome indica é uma rede de telecomunicações que está dispersa por uma grande área geográfica. A WAN distingue-se de uma LAN pelo seu porte e estrutura de telecomunicações. As WAN normalmente são de caráter público, devido à sua dimensão, mas podem eventualmente ser privadas e conseqüentemente alugadas. Duas ou mais redes separadas por uma grande distância e interligadas, são consideradas uma WAN. GREGO (1998)

RDSI: rede digital de serviços. Destina-se a ser uma rede pública mundial de telecomunicações, substituindo as redes existentes e oferecendo uma grande variedade de serviços. Os serviços RDSI são separados em categorias baseadas no escopo e na fonte do serviço. Serviços Básicos (Bearer Services) são aqueles que permitem ao usuário transmitir informações a partir de um aparelho da rede para outro. Esta transferência de informação envolve somente funções das camadas baixas do protocolo de comunicação. Fonte: (http: //penta.ufrgs.br/tp951/rdsi/tele_pri.html)

Internet: é a rede mundial de computadores (servidores) que ligam o usuário com comércio, agências governamentais, universidades e pessoas.

Intranet: tecnologia baseada na Internet para prover usuário em uma rede interna com a utilização de um navegador para rede.

Ethernet: Um protocolo LAN usando uma estrutura de barramento lógica com detecção de portadora de acesso múltiplo com detecção de colisão. 
Fast Ethernet: Um protocolo LAN com uma taxa de transmissão 10 vezes maior do que a rede Ethernet (100 MB/s). Ver Ethernet.

Gigabit Ethernet: Uma LAN que utiliza o padrão desenvolvido pelo grupo de trabalho IEEE 802, operando em GB/s e utilizando o método de detecção de colisões (CSMA/CD)

\section{SERVIÇOS POSSÍVEIS COM A UTILIZAÇÃO DAS REDES}

Tele-Serviços: são serviços providos pela rede, sobre as camadas de transporte de bits, possibilitando comunicação fim-a-fim (usuário-a-usuário) e combinando funções de transporte (serviços básicos) com funções de processamento de informação. Um teleserviço pode ser oferecido por um usuário a outro usuário da rede, ou pela própria rede. No primeiro caso, a rede de serviços meramente transporta bits; no último caso, a rede é provida de serviços adicionais.

e-commerce: é o processo de conduzir transações comerciais usando tecnologias baseadas em Internet. Estas transações podem ser entre 0 negócio e o consumidor ou entre um negócio e outro.

ATM: Asynchronous Transfer Mode. O Modo de Transmissão Assíncrono é uma forma de tecnologia baseada na transmissão de pequenos pacotes de tamanho fixo e estrutura definida denominados células. Estas células são transmitidas através de conexões de circuitos virtuais estabelecidos, sendo sua entrega e comutação feitas pela rede com base na informação de seu cabeçalho. Esta tecnologia se adapta facilmente às exigências de uma grande gama de tráfegos, suportando com isto diferente tipos de serviços. Assim, a tecnologia ATM foi escolhida de forma a dar suporte à implantação da Rede Digital de Serviços Integrados - Faixa Larga RDSI-FL (Broadband Integrated Services Network Fonte:(http://penta.ufrgs.br/rc952/trab2/atm.html)

Banda Larga: é a técnica de transmissão de alta freqüência de dados, voz e vídeo com cabos coaxiais ou fibras ópticas para grandes distâncias.

Fibra óptica: filamento de material dielétrico transparente, comumente de vidro ou de plástico, circular em sua seção transversal, que guia a luz.

Interface: limite compartilhado. O ponto físico de demarcação entre dois dispositivos ou sistemas onde os sinais elétricos, conectores e a temporização são definidos. Define também os procedimentos, protocolos e códigos que permitem dois dispositivos de interagir com o propósito de troca de informação.

Protocolo: conjunto de leis e procedimentos que regem a formatação de mensagens e momento de troca entre dispositivos de uma rede cobrindo o endereço de transmissão, recepção e verificação. 
Wireless: tecnologia que dispensa a utilização de fios. Os dados são transmitidos por antenas, que emitem ondas eletromagnéticas para um aparelho receptor. O telefone celular é um exemplo desta tecnologia.

\section{NOVOS CONCEITOS ARQUITETÔNICOS / CONSTRUTIVOS UTILIZADOS NOS EDIFÍCIOS INTELIGENTES}

Shaft: poço por onde passam as tubulações e fiações no edifício. Deve ser ventilado e de fácil acesso para manutenções. Fonte: http://images.google.com

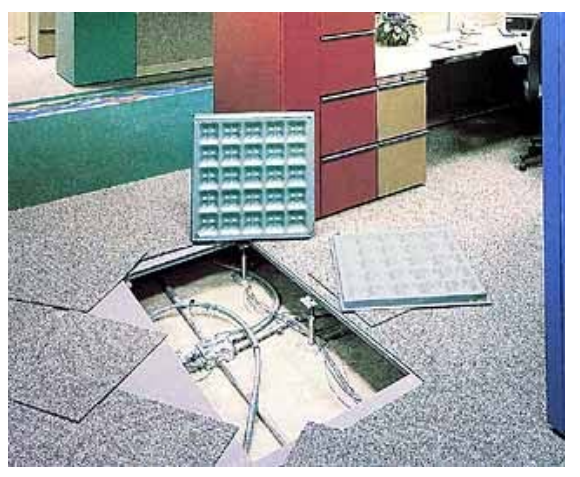

Fig. 57 Exemplo de Shaft

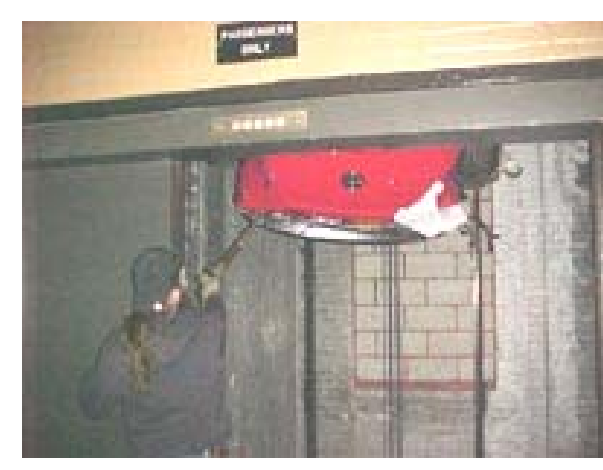

Piso elevado: a função básica desse componente é comportar o cabeamento, proporcionando rápidas mudanças de layout e fácil acesso às instalações; têm entre $10 \mathrm{~cm}$ e 15 $\mathrm{cm}$ de vão entre o piso e a laje.

Fig. 58 Exemplo de Piso elevado

Fonte: http://images.google.com

Fig. 59 Exemplo de Gesso Acartonado

Gesso acartonado ou Drywall: É um tipo de vedação vertical, utilizada na compartimentação e separação de ambientes internos em edificações. É leve, estruturada, fixa ou desmontável, geralmente monolítica, de montagem por acoplamento mecânico e

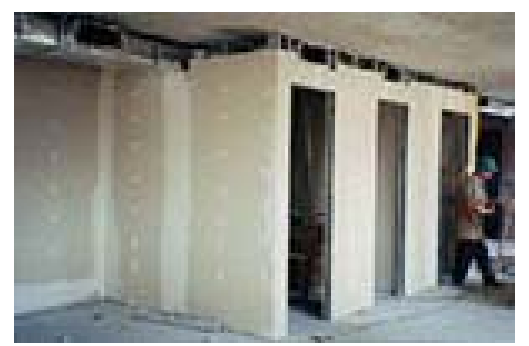
constituída por uma estrutura de perfis metálicos ou de madeira. O fechamento é feito com chapas de gesso acartonado.

Cabeamento Estruturado: Sistema baseado na padronização das interfaces e meios de transmissão, de modo a tornar o cabeamento independente da aplicação e do layout.

Fachadas Ventiladas: possuem uma câmara entre a estrutura e o paramento externo que varia em geral de 5 a $15 \mathrm{~cm}$. O sol incide na face externa e 0 ar dessa camada é aquecido e sobe. Existem aberturas tanto no topo quanto na base da fachada. Há transferência de calor por convecção, desenvolvendo-se um fluxo contínuo de substituição do ar quente por ar frio, aspirado pelas aberturas inferiores.

Fig. 60 Exemplo de Fachadas Ventiladas Fonte: http://www.ceusa.com.br/noticias/cortina_frente.htm

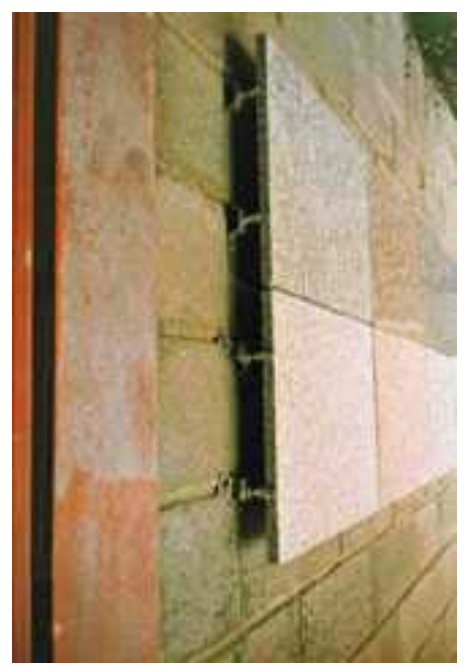


3 Projetos dos Edifícios Inteligentes 


\subsection{Projeto Arquitetônico}

Com o surgimento de novas tecnologias e novos equipamentos, observa-se uma mudança nos espaços dos edifícios. Flexibilidade é a palavra de ordem para garantir vida longa às instalações fixas, seja na manutenção ou em sua manipulação, decorrentes dos avanços contínuos das tecnologias de Comunicação, Informática e Automação.

"Um bom projeto é a única forma segura de garantir economia", afirma o prof. Juan Luís Mascaró (Téchne, no12, 1994). Previsões de possíveis alterações estão sendo feitas já na fase de desenho do projeto, onde a preocupação com itens como localização, orientação, materiais, modulação, estrutura, espaços especiais, segurança, instalações, mobiliário e possíveis ampliações(antes eram esquecidas ou deixadas para depois), agora é de fundamental importância.

A evolução da concepção espacial dos edifícios nas últimas três décadas vem acompanhando as intensas transformações nos conceitos gerenciais das empresas, ditadas pela necessária adaptação das mentalidades herdadas da segunda revolução industrial aos novos parâmetros tecnológicos e concorrenciais. Três aspectos em particular parecem estar repercutindo na evolução dos edifícios. São eles: a busca da qualidade total dos bens e serviços oferecidos, o esforço constante para a redução do seu custo final ao consumidor e a tentativa para consolidar imagens corporativas fortes num mercado inundado de propaganda e marketing. Os três fatores implicam respectivamente: num maior apuro com as áreas de trabalho administrativo, já que se passam a valorizar todas as etapas do ciclo produtivo (desenvolvimento de produto, marketing, venda, controle financeiro, atendimento ao consumidor, etc.) e não só a qualidade do produto final: na otimização do uso do espaço visando o enxugamento de gastos; e na adoção de padrões estéticos coerentes com a imagem que a organização quer transmitir a seus próprios funcionários e a seus clientes.

Os novos parâmetros da economia globalizada e os novos métodos de trabalho introduzidos com 0 desenvolvimento da informática e da telemática vêm proporcionando, apesar da tônica recessiva que domina o período atual, um redesenho geral dos edifícios tanto dentro quanto fora do Brasil. Mesmo com a eficiência global como principal referência, o edifício moderno não pode mais ignorar as exigências "organizacionalmente corretas" do conforto ambiental, da ergonomia e da humanização dos espaços.(Vasco Caldeira, 2000).

\section{Escritório: Um Século de Conceitos}

Dos diferentes tipos de espaços construídos pelo homem para abrigar suas atividades cotidianas, os escritórios se destacam como os mais eminentemente contemporâneos. Essa característica se manifesta não apenas nas radicais transformações por que passam durante este último 
século (de fato, transformações muito mais fundamentais do que aquelas sofridas pelos espaços da habitação ou da fábrica), mas também por serem os escritórios os espaços onde um número cada vez maior de pessoas passa uma parcela cada vez maior do seu tempo.

Abordaremos de forma resumida a evolução histórica desse conceito de escritório e os diferentes modelos de organização espacial que the corresponderam. Posteriormente serão abordadas as questões tecnológicas relacionadas com o projeto de escritórios na atualidade, no Brasil e no resto do mundo.

Data de 1890 a primeira teoria administrativa científica - taylorismo (Frederick W. Taylor, 1856-1915 - que preconiza a segregação espacial como meio de reafirmar a hierarquia e defende a padronização do mobiliário e a rigidez dos lay-outs como forma de assegurar a disciplina e a linearidade do processo de trabalho, como numa linha de montagem).

Fig. 61 Exemplo de Escritório Antigo Fonte: http://www.luxalon.com.br/

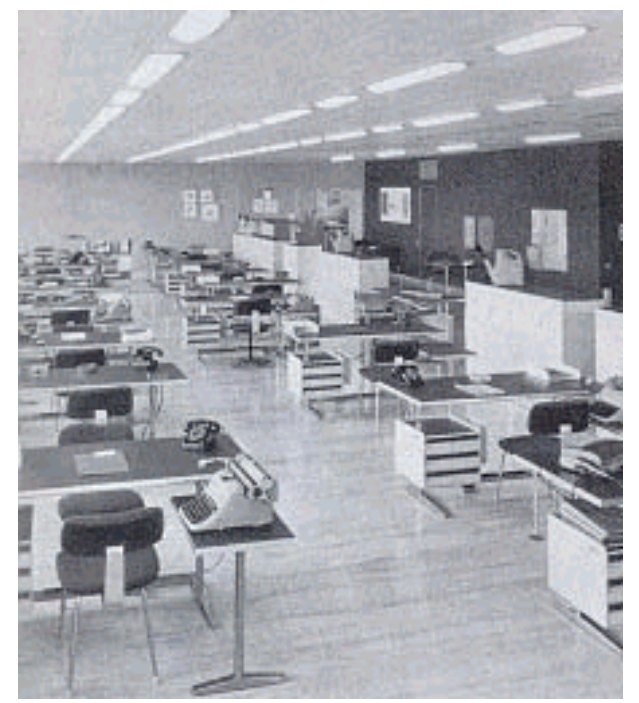

Em 1913, J. Willian Schulze (The American Office) inicia o estudo dos fluxos de trabalho, a medida de sua duração e o desenho do espaço e das ferramentas necessárias à sua execução. É quando se institui a noção de módulo espacial, ainda dentro de uma concepção puramente mecânica que ignora os modernos conceitos ergonômicos, desenvolvidos só anos mais tarde.

A primeira crítica do taylorismo, após a Primeira Guerra, é feita por Elton Mayo, com o movimento chamado Escola das Relações Humanas. Este substitui o método coercitivo pelo emprego da psico-sociologia e da comunicação interna, fazendo com que os funcionários se sintam participantes das decisões da empresa. Os principais desdobramentos dessas idéias são, por um lado, o trabalho que vê na auto-satisfação e na participação criativa, o mais eficaz estímulo ao trabalho e à responsabilidade e, por outro lado, a proposta apresentada em 1958 pela empresa alemã de consultaria Quickborner Team, do revolucionário sistema de planejamento de escritórios conhecido como Escritório Panorâmico.

Com base nessas contribuições e percebendo rapidamente os novos rumos que a organização espacial dos escritórios estava tomando, a moveleira norte-americana Herman Miller cria um centro de pesquisas em Michigan comandado por Robert Propst, cujo trabalho resulta em 1964 no lançamento comercial do primeiro sistema de escritório panorâmico, o Action Office. Esse sistema é mais do que uma simples linha de mobiliário para escritórios. Ele supõe toda uma concepção sobre a funcionalidade do trabalho, introduzindo diferenciais de privacidade através de divisórias móveis e 
moduláveis que não apenas delimitam sub-ambientes individuais (ou para pequenas equipes), como também servem de suporte para os planos de trabalho, prateleiras, armários, arquivos, cabeamento e iluminação, de modo que cada funcionário tenha ao alcance da mão todas as ferramentas de trabalho necessárias. Por ser modulável, o sistema permite a agregação de componentes diferenciados consoante as necessidades de cada atividade, bem como a justaposição de vários postos de trabalho no caso de atividades inter-relacionadas. O Action Office foi concebido de forma a atender as especificidades de cada funcionário e de cada departamento, sem, contudo criar uma compartimentação excessiva e definitiva da planta aberta original.

Diferentemente da proposta americana, que hoje é adotada por inúmeros fabricantes com algumas variações, o modelo alemão de escritório panorâmico propõe a abolição radical das divisórias e da separação física entre os postos de trabalho além dos dispositivos de armazenagem (estantes, arquivos, armários) que são centralizados em áreas acessíveis a todos. Sem o aproveitamento vertical do espaço (armários e prateleiras sobre os próprios planos de trabalho) o aproveitamento global do espaço pelo sistema alemão acaba sendo inferior ao do modelo Action. Entretanto, ele apresenta ganhos, em termos de flexibilidade na disposição do mobiliário (Design \& interiores, set/out 1987).

A partir desses dois modelos, que ainda hoje são referência, os anos 70 foram os da disseminação e desenvolvimento dos sistemas de mobiliário, inclusive no Brasil, enquanto os anos 80 foram os da retomada da estetização não só no mobiliário, como também dos equipamentos eletro-eletrônicos.

A padronização um tanto monótona, característica dos primeiros tempos da indústria de componentes para escritórios, aliada às novas exigências em termos de identidade visual, ditadas pela importância crescente da comunicação, justificam a excessiva semantização do design ocorrida na década passada. Nesse mesmo período, padrões ergonômicos e de conforto ambiental cada vez mais exigentes, típicos de um momento de facilidades econômicas, passaram a reclamar o aperfeiçoamento de novos materiais e tecnologias, o que resultou no surgimento de uma variedade maior de opções e melhor performance funcional dos componentes.

Uma das últimas revisões das teorias organizacionais com repercussão sobre - planejamento dos espaços para escritórios ocorre com a Teoria dos Sistemas (Robert Simon, Victor Thompson). Esta critica no behaviorismo a manutenção de uma estrutura hierárquica considerada burocratizante e inibidora da criatividade e de iniciativas individuais.

Baseada nessas novas Idéias a Herman Miller lança em 1985 o sistema Ethospace, no qual são minimizadas as diferenças de acabamento entre peças de mobiliário destinadas a diferentes níveis hierárquicos e onde todos os componentes procuram metaforicamente evocar elementos arquitetônicos (paredes, janelas, tijolos, etc.). Introduz-se uma escala reconhecível de forma a humanizar os "open space" convencionais, 
considerados como excessivamente artificiais e impessoais, subtraídos de qualquer relação com a Arquitetura do edifício em si e com a paisagem exterior. Seu sistema de divisórias permite combinar diferentes alturas, graus de transparência e tipos de acabamento, possibilitando a criação tanto de salas completamente privativas com paredes de altura total, até arranjos do tipo panorâmico.

Os anos 90 nascem sob o signo da contenção econômica e termos mundiais que justifica a tendência atual para maior simplicidade formal, para uma flexibilidade mais real e menos retórica e para sucesso do produto industrial sob medida. Isto é uma tendência para sistemas, sejam eles de móveis, de forros ou de divisórias que, com um mínimo de limitações métricas ou de padronagens, permitam oferecer uma grande variedade de soluções em prazos curtos e com pequena variedade de itens em estoque.

Em termos de tipologia de layout a tendência atual é para os sistemas combinados, que resgatam as salas individuais ou para pequenos grupos, situadas junto às faces ensoladas, deixando o miolo do pavimento livre para ser organizado segundo uma das múltiplas variantes dos sistema do tipo Action Office ou panorâmico disponíveis hoje em dia no mercado.

Nota-se forte tendência para que as divisórias fixas incorporem grandes painéis de vidro complementados por persianas verticais e horizontais, cortinas sanfonadas ou de enrolar, dando ao conjunto um aspecto de maior leveza e integração, ao mesmo tempo em que permite criar uma maior privacidade quando desejada.

Outra marca contemporânea é a versatilização do uso dos espaços imposta pela flexibilização das relações de trabalho-consultoria, trabalho temporário ou em tempo parcial - que determina o uso alternado de um mesmo posto de trabalho por diferentes pessoas. Essa tendência acaba sendo facilitada pela presença do computador que, a despeito do nome (Personnal Computer), é um instrumento de trabalho relativamente impessoal servindo a diferentes usuários.

\section{Siłuação Brasileira}

Mais recentemente, a abertura do mercado tem facilitado a importação de móveis, carpetes, forros, persianas e outros componentes industrializados, bem como de insumos antes inacessíveis, tornando possível o aprimoramento tecnológico dos produtos finais aqui fabricados.

A nova realidade tem permitido que empresas estabelecidas no Brasil há muitos anos, possam atualmente oferecer ao público local, artigos produzidos por Filiais de outros países ou por outras empresas que passam a representar no Brasil ou ainda com as quais aqui se associam de forma mais global. 
Com as novas possibilidades de comércio internacional e com a estabilização da economia brasileira, a Arquitetura de interiores no ramo específico dos escritórios entra definitivamente numa nova fase.

A cultura empresarial está mudando de forma consistente, abrindo perspectivas favoráveis para os profissionais e as indústrias comprometidas com a qualidade funcional e estética de suas criações.

\subsection{Projeto dos Postos de Trabalho}

O ideal é dividir o espaço em estações de trabalho.

A percepção, tanto das empresas usuárias quanto dos fornecedores de produtos, de que só oferecer tecnologia não é suficiente para criar um ambiente saudável e produtivo no escritório, fez emergir no Brasil, nos últimos anos, um conceito aplicado há mais tempo em países desenvolvidos: o do escritório inteligente. "Ele não é apenas um amontoado de máquinas que só falta falarem, mas, acima de tudo, uma combinação de ergonomia e tecnologia em benefício da saúde e do conforto físico e mental das pessoas", define Ricardo Aronovit, da Flex Editora e Eventos(promotora da Office Solution, uma mostra anual do que há de mais moderno em Arquitetura, instalações e planejamento para escritórios inteligentes).

Ao contrário dos anos 80 , quando as máquinas, o mobiliário e os sistemas de iluminação e climatização eram o centro das atenções, no escritório dos anos 90 o que mais interessa são as pessoas. Por uma razão muito simples: para manter um escritório funcionando, uma empresa gasta entre $6 \%$ e $7 \%$ em instalação física e mais de $90 \%$ com mão-de-obra. Isso justifica o esforço das companhias em investir em projetos inteligentes. $O$ ambiente de trabalho favorável reflete dentro e fora da organização e possibilita um relacionamento mais dinâmico com clientes e fornecedores. "Vivemos a era da velocidade, e quem não responder rápido às solicitações dos clientes e dos fornecedores estará morto em breve", prevê Aronovit.

No Brasil, já é possível detectar a tendência até mesmo em pequenas firmas. Layout aberto com divisórias baixas (1,10 m de altura), células de trabalho, cadeiras reguláveis e o piso elevado que serve para embutir o cabeamento da rede de computadores e dos telefones com sistema reconfigurável de ramal.

Fig. 62 Escritório moderno tendência

Fonte: Design \& interiores set/out 1987.

Completam $\circ$ projeto luminárias anti-reflexivas, sistema de ar condicionado com controle automático da temperatura ambiente e

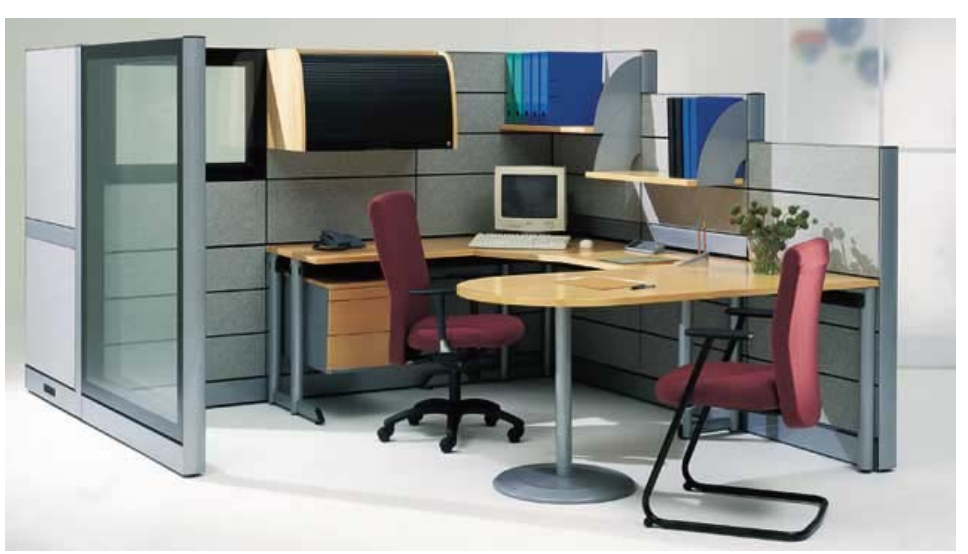


forro acústico para minimizar a propagação de ruídos. Luminárias com difusor de luz, acessórios para embutir fios e cabos e apoio retrátil para teclado de computador são alguns itens usados nos escritórios inteligentes.

Tanto em empresas pequenas quanto em multinacionais, são visíveis as mudanças que as novas tecnologias e layouts estão provocando na cultura administrativa das empresas. A principal delas, a queda das paredes, deixa claro que o território demarcado das salas fechadas, salvo algumas exceções, é coisa do passado nos escritórios modernos. Agora, divididos apenas por biombos de 1,10 a 1,60 m de altura, os ambientes são abertos. Neles, as pessoas têm a "privacidade" de sua estação de trabalho, mas ao mesmo tempo operam em grupos (células), agilizando a troca de informações e a tomada de decisões na empresa. Isso exige uma completa reestruturação dos conceitos de gerenciamento e fluxo de trabalho.

Nos "open offices" apenas a alta diretoria ainda mantém suas salas privativas, mas não fechadas como antes. Em vez das paredes, os vidros transparentes cuidam da integração dessas áreas com o restante do escritório e permitem a comunicação mais eficaz entre os executivos e os demais empregados. A privacidade eventual pode ser obtida com micropersianas internas e até cristal líquido, uma das últimas novidades no exterior para tornar uma divisória opaca ou transparente ao simples toque de um botão.

Hoje, os escritórios dividem-se em territoriais e não-territoriais, segundo Eduardo Gyurkovitz, gerente de marketing da L'atellier Móveis.

Os territoriais são os mais utilizados. Partem do princípio de que cada funcionário tem seu posto de trabalho e podem ser montados nos estilos "High Performance Team" e "Combi Office". O High Performance possui uma configuração para estimular o trabalho em equipe, como as redações de jornal e os escritórios de planejamento, entre outros. Já o Combi Office é aplicado em setores que exigem alta concentração de seus funcionários e caracteriza-se por pequenas salas fechadas, geralmente na periferia do edifício. A parte central é reservada para o pool de equipamentos de uso comum (fax, impressoras, etc.), estações de trabalho para pessoal de apoio (secretárias, assistentes, etc.) e áreas de estar e de convívio social.

Os escritórios não-territoriais, conforme Gyurkovitz, ainda são pouco utilizados, porque mexem drasticamente com a maneira de trabalhar da empresa e com o comportamento de seus colaboradores. Neles, não existe um posto de trabalho para cada funcionário. Dentro desse conceito, os modelos mais conhecidos são o "Free Address" e o "Hoteling". O Free Address é usado principalmente para média gerência e demais funcionários. As mesas ficam completamente vazias: nenhum sinal de computador ou papel. Sobre elas, vêem-se apenas um telefone e algumas tomadas. O funcionário chega com seu notebook, pega seus gaveteiros volantes, pluga a máquina na rede, programa o ramal telefônico para seu número pessoal e torna-se dono daquele posto. É indicado para atividades cujos profissionais 
permaneçam pouco tempo no escritório, como vendedores e prestadores de serviço.

Já o Hoteling, como o próprio nome sugere, funciona como o sistema de reservas de hotel. Sua configuração arquitetônica é parecida com a do Combi Office, mas as salas não possuem "donos". O funcionário entra em contato com o pessoal de apoio da empresa e faz a reserva de uma das salas por um número de horas previamente acertado.

"Estudos recentes realizados nos Estados Unidos apontam a utilização desses conceitos como responsável pela redução de $30 \%$ a $40 \%$ do uso de espaço nos escritórios", afirma Gyurkovitz. Segundo ele, no caso do Free Address é possível otimizar a ocupação de tal forma que até cinco funcionários usufruam uma mesma estação de trabalho.

\section{Local de Implantação do Escritório}

Além da definição do layout do escritório, o ponto comercial é outro item a ser pesado. Os consultores aconselham o empresário a fazer uma previsão de gastos com a compra ou aluguel do imóvel.

Nesse quesito, as transformações pós-computador ocorridas no espaço físico dos escritórios joga a favor das empresas. $O$ uso de equipamentos de informática não só eliminou papéis e muitos armários de arquivo, como diminuiu em um terço as áreas dos escritórios. O próprio parâmetro de área adequada para cada funcionário baixou de $16 \mathrm{~m}^{2}$ para $10 \mathrm{~m}^{2}$ na construção de novos edifícios administrativos. Com a possibilidade da transmissão remota de dados, via rede Ethernet ou Internet, muitas empresas também acabaram deslocando seus escritórios para regiões mais nobres e visíveis, enquanto a fábrica ou o depósito ficam em áreas mais baratas.

\begin{tabular}{|l|c|}
\hline \multicolumn{2}{|c|}{ Preços médios de aluguéis de escritórios* } \\
\hline Região & $\begin{array}{c}\text { Preço médio } \\
\text { R\$/ } / \mathbf{m}^{2}\end{array}$ \\
\hline SÃO PAULO & \\
\hline $\begin{array}{l}\text { Centro (Rua Barão de Itapetininga, Praça do Patriarca, Rua Direita, Rua } \\
\text { São Bento) }\end{array}$ & 5 a 7 \\
\hline Av. Paulista (Próximo à Rua Augusta) & 25 a 40 \\
\hline Pinheiros (Av. Faria Lima, próximo ao shopping lguatemi) & 25 a 50 \\
\hline Brooklin (Av. (Luís Carlos Berrini) & 25 a 40 \\
\hline Vila Mariana (Rua Domingos de Morais) & 20 a 30 \\
\hline Paraíso (Ruas Cincinato Braga, Coronel Oscar Porto e Cubatão) & 20 a 30 \\
\hline RIO DE JANEIRO & \\
\hline
\end{tabular}




\begin{tabular}{|l|c|}
\hline Centro (Av. Rio Branco e Av. Getúlio Vargas) & 8 a 35 \\
\hline Praia do Flamengo & 15 a 30 \\
\hline Praia de Botafogo & 20 a 45 \\
\hline RECIFE & \\
\hline Praia de Boa Viagem & 20 a 25 \\
\hline Bairro da Boa Vista & 18 a 20 \\
\hline CURITIBA & \\
\hline Centro e bairro do Batel & 6 a 16 \\
\hline
\end{tabular}

Tabela $1-(*)$ Valores para prédios em bom estado.

Fontes: http://www.luxalon.com.br

A observação de alguns detalhes sobre as características do ponto pode evitar problemas futuros para a empresa. Em São Paulo, por exemplo, o centro da cidade oferece aluguéis baratos, boa infra-estrutura de transporte público, mas o empresário precisa estar preparado para conviver com as dificuldades de acesso de carro e com prédios antigos, na maioria dos quais as redes elétrica e de telecomunicações estão mal estruturadas. Já a avenida Paulista tem bom transporte público, fácil acesso, grande adensamento de pessoas, prédios modernos, mas os custos do aluguel são altos. Como visto na tabela 1.

\begin{tabular}{|c|c|c|}
\hline & \multicolumn{2}{|l|}{$\begin{array}{l}\text { O preço do conforto } \\
\text { O custo médio de projetos e instalações de escritórios* }\end{array}$} \\
\hline Padrão & Características & $\begin{array}{l}\text { Preço em } \\
\mathrm{R} \$ / \mathrm{m}^{2}\end{array}$ \\
\hline A & $\begin{array}{l}\text { Inclui o projeto do arquiteto, mobiliário ergonômico, } \\
\text { acabamento acústico, sistemas de iluminação e de ar } \\
\text { condicionado inteligentes, carpete importado } \\
\text { antibactericida, redes estruturadas, tudo em padrão luxo. }\end{array}$ & 960 a 1.100 \\
\hline B & $\begin{array}{l}\text { Inclui o projeto arquitetônico, iluminação, ar condicionado, } \\
\text { mobiliário, divisórias, acabamentos e instalações do tipo B. }\end{array}$ & 750 a 950 \\
\hline C & $\begin{array}{l}\text { Inclui o projeto do arquiteto, mobiliário, acabamentos e } \\
\text { instalações do tipo C. }\end{array}$ & 500 a 749 \\
\hline D & $\begin{array}{l}\text { Inclui projeto arquitetônico, mobiliário, acabamentos e } \\
\text { instalações do tipo D. }\end{array}$ & 350 a 500 \\
\hline
\end{tabular}

Tabela 2 - $(*)$ Graus de simplificação das instalações: o tipo B, por exemplo, é praticamente igual ao A, mas com materiais menos nobres e sem tratamento acústico. Os tipos $C$ e $D$ incluem mobiliário simples e têm menos flexibilidade nos pontos de fixação das divisórias e das estações de trabalho.

Fonte: http://www.luxalon.com.br.

Seja qual for a localização escolhida, para equipar o escritório de forma inteligente é necessário começar cuidando das instalações básicas, como o cabeamento das redes de telefones, computadores e luz. 
O mercado atual também exige das empresas agilidade para operar mudanças de ritmo, crescimento ou encolhimento rápido e mudança no perfil das atividades.

Em função disso a flexibilidade dos componentes arquitetônicos para escritórios e a possibilidade de que ao menos parte das modificações possa ser operada pelos próprios utilizadores, passam a ser quesitos básicos na avaliação dos mesmos.

Sistemas de mobiliário que permitam a fácil substituição ou acréscimo de um componente, pisos falsos que permitam acesso a instalações técnicas sem prejuízo do funcionamento e do aspecto visual do revestimento, sistemas de cabeamento estruturado que permitam a alteração na distribuição dos pontos de telefonia, transmissão de dados ou de energia sem necessidade de reforma da fiação ou da tubulação, são algumas das conquistas da evolução recente do escritório.

Outro aspecto da flexibilização diz respeito ao conforto ambiental. $\bigcirc$ uso racional da energia tornou-se uma obsessão planetária. Por isso "a inteligência" e a flexibilização dos sistemas de iluminação e de climatização são fundamentais, permitindo-lhes ajustar seu desempenho às alterações climáticas e ao ciclo de trabalho, segundo o modo de funcionamento do "mínimo consumo ideal".

Um ambiente confortável não pode prescindir ainda de um bom sistema de climatização. O ideal é que a refrigeração do ar propicie temperatura ambiente entre $20^{\circ} \mathrm{C}$ e $23^{\circ} \mathrm{C}$, conforme determina a norma Brasileira sobre ergonomia. Os sistemas mais sofisticados permitem o controle automático e remoto de velocidade, temperatura e direcionamento do ar.

As modernas tecnologias disponíveis em iluminação, como os sistemas Trios, da Philips, chegam ao requinte de operar com sensores capazes de dimensionar a luz artificial de acordo com a luz natural que entra pelas janelas.

A intensidade da luz é regulada por controle remoto e os reatores eletrônicos propiciam uma economia de $70 \%$ em relação aos modelos comuns. Luminárias inteligentes, como a T5 Super 80, da Lustres Projeto, possuem refletores de alumínio anodizado de alto brilho, que difundem a luz no ambiente de trabalho quase como um espelho, sem refletir na tela dos computadores. Segundo informações da empresa, com duas lâmpadas, ela tem a mesma eficiência de outra luminária comum com quatro lâmpadas.

(http://www.creare.com.br)

A flexibilização das plantas passou a exigir dos forros igual versatilidade, de modo a permitir sem grandes transtornos, o deslocamento de paredes divisórias, de grelhas de ar-condicionado e de refletores de luz.

Os forros suspensos modulados cumprem esse papel, constituindo verdadeiros painéis técnicos, facilitando o acesso e a manutenção do 
emaranhado de cabos, dutos e canalizações situados no vão que confinam sob cada laje de cobertura.

Além dessa finalidade estão as funções acústica e estética, sendo a primeira decisiva para o conforto físico de espaços ocupados por muitas pessoas e equipamentos e a segunda fundamental para o conforto visual e para a imagem de marca da empresa.

Nos primórdios dos escritórios não havia distinção tão radical entre os seus espaços e aqueles destinados à habitação, exceto pelo mobiliário. Hoje em dia pode-se dizer que os sistemas de forro, sobretudo metálicos, são componentes fundamentais para a caracterização do escritório moderno.

A configuração aberta dos escritórios também exige tratamento acústico para evitar que os ruídos dificultem a comunicação e a concentração dos trabalhadores. Piso frio, como mármore e granito, e gesso e vidro nas paredes e teto fazem o som reverberar pelo ambiente. Os forros de lãs de vidro e de rocha e os painéis verticais portáteis são algumas opções para absorção de ruídos. O carpete também pode funcionar como isolante acústico.

Com a infra-estrutura definida, deve-se pensar com cuidado no mobiliário, a alma da flexibilidade e da integração dos escritórios modernos. "Os móveis inteligentes têm de estar preparados para receber cabeamento, eletrificações, periféricos, posições específicas para teclado e mouse, além de arquivos e prateleiras suspensas em painéis, visando a racionalização e a fácil integração dos planos de trabalho", afirma Eduardo Gyurkovitz, da L'atellier. Os móveis ganharam formas orgânicas, com características funcionais que colocam o ser humano no "centro nervoso" da estação de trabalho. "Essas inovações dão ao usuário total controle sobre o ambiente, possibilitando o desempenho de suas funções com mais conforto, segurança e eficiência".

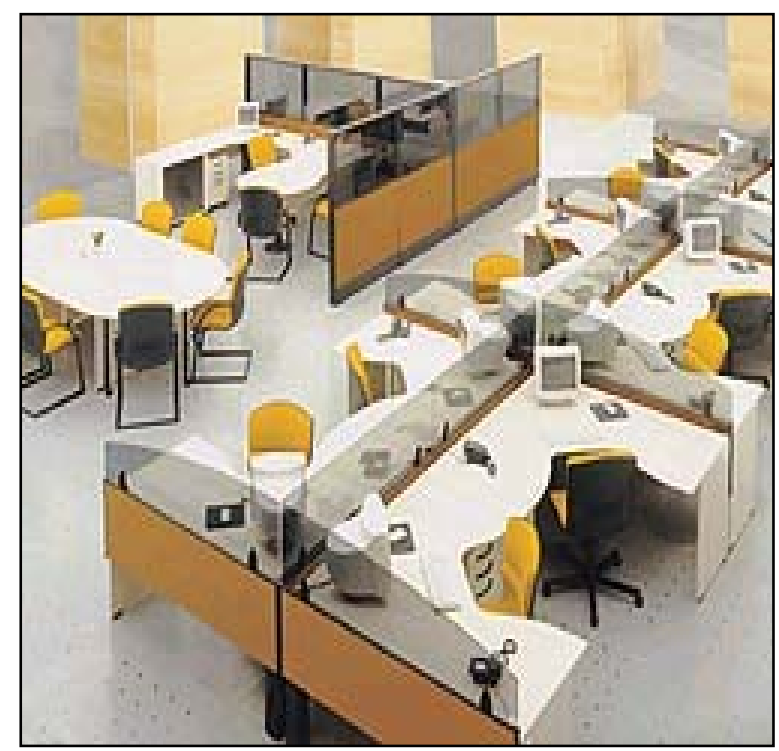

Fig. 63 Sistema K fabricado pela Giroflex

As principais inovações no segmento são as peças modulares com rodinhas (mesas, armários, etc.), para facilitar a reconfiguração rápida das estações de trabalho, e a presença cada vez maior de recursos ergonômicos, como a superfície anti-reflexiva, para impedir a fadiga visual.

Fonte: http://www.asbea.org.br/jornal/j63/artigo2_63.htm 


\subsection{Projeto Urbanístico}

À medida que o mundo está ficando cada vez mais urbanizado, computadores de última geração e sistemas telemáticos digitais vão penetrando em todas as áreas da vida urbana.

As duas características que definem a civilização contemporânea, embora questionáveis, são os saltos paralelos rumo a um planeta mais urbanizado e a uma sociedade cada vez mais baseada na rapidez dos fluxos eletrônicos de informação.

A maioria das mudanças contemporâneas nas economias, na cultura e na vida social das cidades parece estar relacionada à aplicação de novas infra-estruturas de telecomunicações e serviços, ligadas a computadores ou a equipamentos computadorizados, visando a formação de redes "telemáticas". Tudo isso transcende, quase que instantaneamente, as barreiras espaciais, de forma a reordenar as limitações de tempo e espaço entre cidades.

Pequenos pontos e lugares, totalmente separados, estão sendo interligados mundo urbano afora, com um mínimo de tempo diferido - ou seja, quase que se aproximando do 'tempo real'. Fluxos globais de voz, e-mail, dados, vídeo, fax e sons estão aumentando exponencialmente, fazendo com que as cidades fiquem cada vez mais atadas a extensas redes de comunicação humana, a fluxos de serviços e mídia, aos fluxos de força de trabalho baseados no 'teletrabalho', e aos fluxos de dinheiro eletrônico.

Os corredores que interligam as cidades, sejam eles terrestres, por oceano ou aéreos, estão agora se configurando como uma imensa cobertura de "treliças" ou "teias", fazendo as ligações dos fluxos de telecomunicação avançada. Tudo isso conecta os sistemas urbanos a uma grade eletrônica a world wide web - www, coloquialmente Web.

Toda a noção geralmente aceita sobre a natureza do espaço, do tempo, da distância e dos processos da vida urbana são, igualmente, questionáveis. A vida urbana parece mais volátil e acelerada, mais incerta, mais fragmentada e mais difícil de entender hoje do que em qualquer outro momento desde o final do século passado. Então, fica claro que as cidades contemporâneas não são apenas densas aglomerações físicas de edifícios, de entroncamentos de redes de transporte, ou os principais centros da vida econômica, social e cultural. Deve-se considerar, também, o papel das cidades como sistemas eletrônicos que compõem as redes de telecomunicação e telemática. As áreas urbanas são os centros dominantes de demanda das telecomunicações e os centros nervosos de irradiação das grades eletrônicas. De fato, parece existir uma conexão forte e sinérgica entre as cidades e essa nova infra-estrutura de redes. Tais implicações nos remetem a problemática tratada pelo conceito de Urbanização Virtual que é o objeto de pesquisa do grupo e-urb Urbanização Virtual e Serviços Telemáticos.(Camargo, 96, 98,2000) 


\section{São Paulo e as Transformações Urbanísticas}

A abertura política e econômica que teve início nos anos 80 inserem São Paulo na rede de internacionalização, atraindo capital, empresas e serviços, que estabelecem novos referenciais e dá início a um novo processo de transformação, baseado no domínio de uma cultura universal.

A Marginal Pinheiros e seus arredores, a partir daí, passa a ser pólo dos grandes edifícios de escritórios e centros administrativos, como o Birmann 21, - Terra Brasilis, o World Trade Center, o Plaza Centenário, o Centro Empresarial Nações Unidas entre outros.

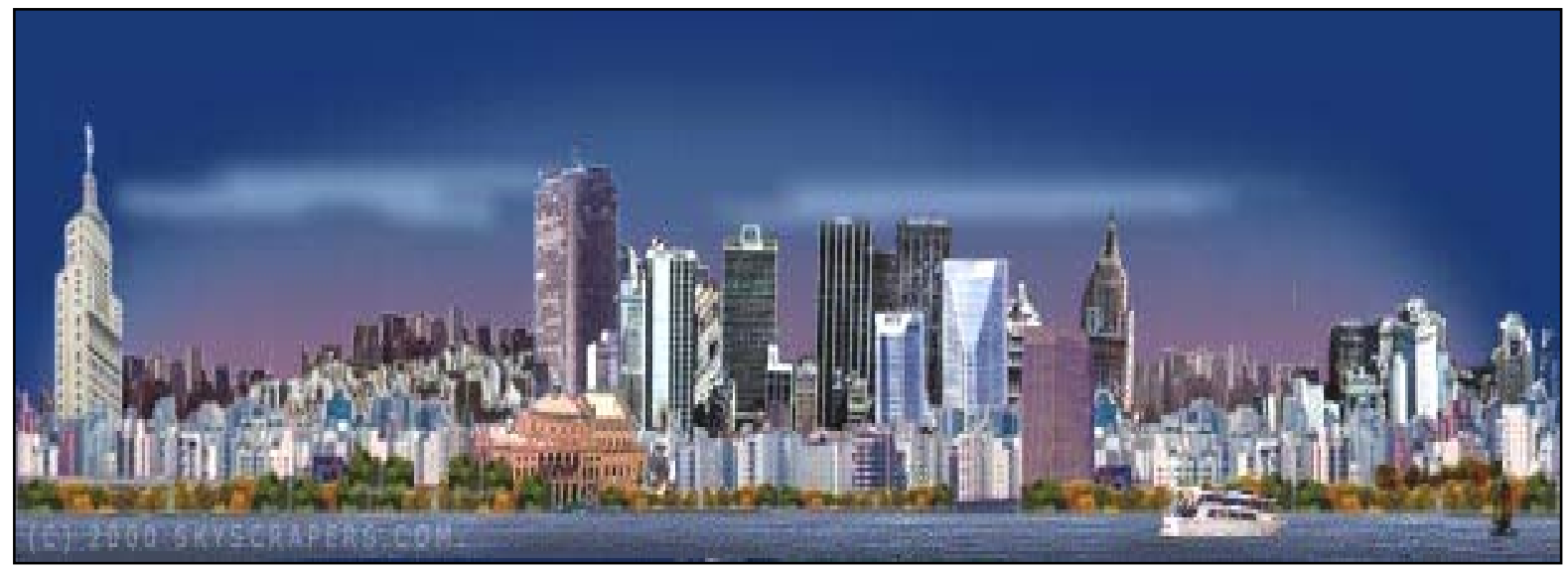

Fig. 64 Maquete eletrônica dos Edifícios da Marginal Pinheiros - SP

Fonte: http://www.bolsaimoveis.com.br/

Ao mesmo tempo, ocorrem mudanças na "dinâmica da cidade", onde o conceito de pólo tradicional no sentido de um conglomerado de escritórios num determinado lugar está evoluindo para um "conceito mais longitudinal", condicionado pela perspectiva urbanística decorrente do espaço visual que o Rio Pinheiros proporciona nesse local, conforme relata o arquiteto Marc Rubin.

O centro de negócios antigamente, com seus prédios repletos de pequenas salas e corredores situava-se nas imediações da Sé. Depois passou para o outro lado do Anhangabaú, até que se transferiu para a Av. Paulista e, em seguida, para a Faria Lima. A Paulista já está saturada e a Faria Lima também. Esse pólo está passando agora para a Marginal Pinheiros (impondo novas determinantes aos projetos Urbanístico, Paisagístico e Arquitetônico), onde existe essa abertura visual a que nos referimos o que só aconteceu no Vale do Anhangabaú, em outro tempo.

\section{A Berrini e seu desenvolvimento}

A região da Avenida Engenheiro Luís Carlos Berrini, situada no trecho da Marginal Pinheiros, entre as pontes Engenheiro Ary Torres (Avenida dos Bandeirantes) e do Morumbi, mudou a paisagem da cidade com a concentração de grandes empreendimentos ocorrida nos últimos anos. 
Um conjunto de fatores como o surgimento de novos edifícios com tecnologia avançada, a intervenção do poder público suprindo as carências de infra-estrutura, a saída das indústrias e a expansão da cidade em direção à Zona Sul influenciaram decisivamente no crescimento da Berrini. O resultado de tudo isso é a atração contínua de empresas de primeira linha para a região.

A Região da Berrini veio crescendo ao longo da década de 90, ganhando aceleração na segunda metade da década com o lançamento de grandes empreendimentos como o World Trade Center em outubro de 1995, um complexo misto de escritórios, hotel e shopping temático, que se situa exatamente ao lado da Torre Norte. O World Trade Center e o Centro Empresarial Nações Unidas (CENU), formam um centro comercial/empresarial de alto padrão, tornando-se referência em São Paulo.

Atualmente a Região da Berrini concentra alguns dos edifícios de escritórios mais avançados da cidade. Muito bem localizada, a região vem sofrendo um constante crescimento imobiliário, com projetos de empreendimentos hoteleiros e comerciais de alto padrão. Recentemente, por exemplo, houve a inauguração dos escritórios da TV Globo. Alguns dos projetos em andamento são:

- Hotel Hilton, ao lado do mesmo complexo da Torre Norte, o CENU;

- Hotel Hyatt, próximo à Ponte do Morumbi;

- Edifício sede do Bank Boston, junto ao Hotel Hyatt.

Além disso, é uma região já estabelecida com sedes regionais de grandes multinacionais como do Bank Boston, Hewlett Packard, Nestlé, Philips, Banco Sudameris, TV Globo, Andersen Consulting, Daimler Chrysler, Banco Chase Manhattan, Computer Associates, Monsanto, Nokia, Mastercard, Walt Disney, BCP, SAP, Deutsche Bank Alex Brown, American Express e Microsoft.

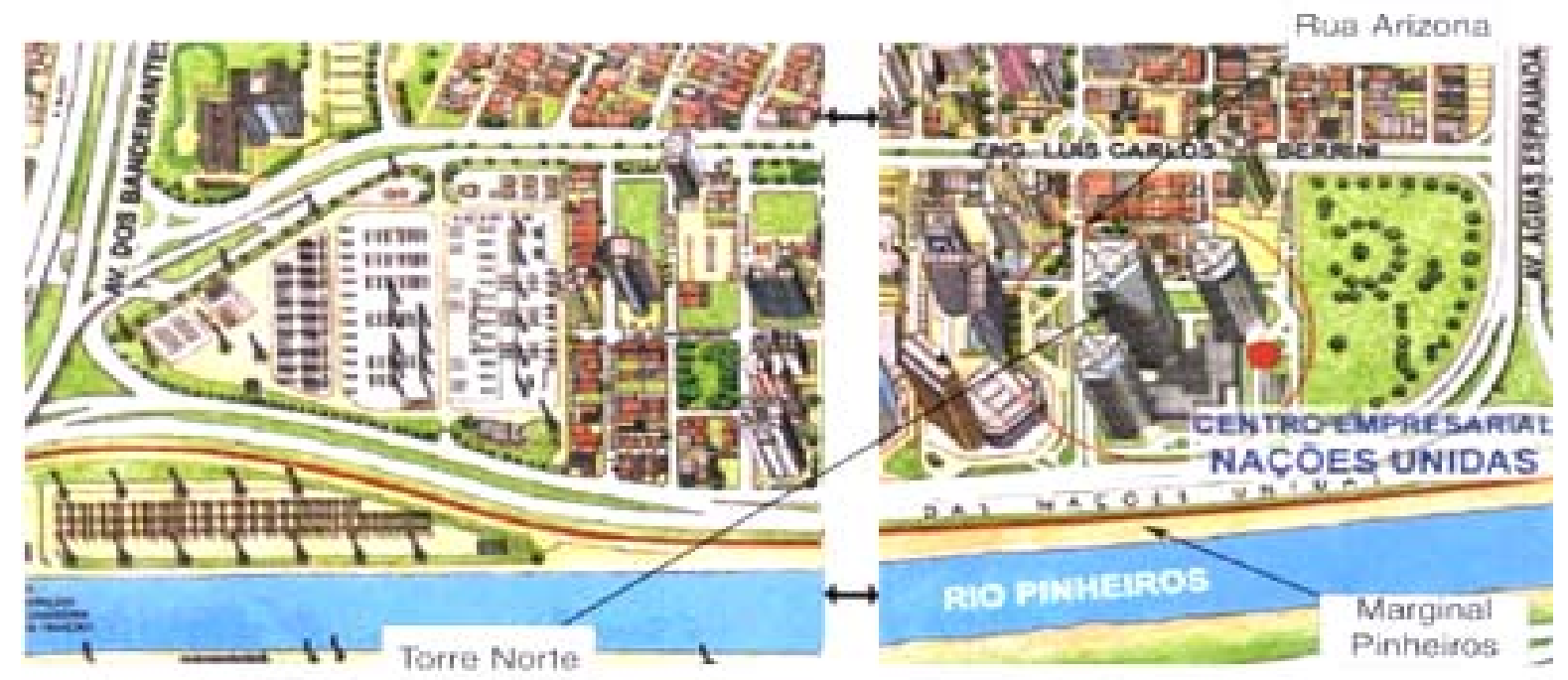

Fig. 65 Destaque para o CENU, na marginal Pinheiros - SP

Fonte: http://www.bolsaimoveis.com.br/cenu_convencoes/Convencoes3.htm 
A ocupação empresarial dessa zona é imbatível. São mais de 900 empresas instaladas na região. Muitas delas pertencentes ao seleto grupo das maiores e melhores empresas nacionais e multinacionais que atuam no Brasil. A tecnologia empregada na construção de vários edifícios da Berrini pode ser colocada entre as mais modernas da América latina.

Quase $75 \%$ dos edifícios da região possuem sistema de ACC (Ar Condicionado Central) e a grande maioria dos edifícios incorpora os mais modernos processos construtivos e equipamentos que são a última palavra em tecnologia.

E sua grande maioria os edifícios possuem lajes superiores a $500 \mathrm{~m}^{2}$ de área útil, um irresistível convite às grandes organizações que querem se fixar na região.

O segmento de escritórios foi o maior responsável pelo desenvolvimento da região. A Berrini é hoje a terceira maior concentração de escritórios da cidade - perdendo apenas para o Centro e a Paulista, regiões que se consolidaram há muito mais tempo - e a primeira em volume de $\mathrm{m}^{2}$ úteis de escritórios de alto padrão.

É também a região mais cara da cidade, onde são praticados os preços mais altos por metro quadrado útil de locação de escritórios, comprovando a tendência de que os valores estão mais relacionados ao padrão dos edifícios do que à sua localização.

Em decorrência do desenvolvimento do mercado de escritórios, várias redes internacionais de hotelaria demonstraram interesse em instalar-se na região, a fim de atender à crescente demanda gerada pelo "turismo de negócios".

O Gran Meliá foi o primeiro hotel de categoria 5 estrelas a instalar-se, fazendo parte do complexo World Trade Center (WTC), inaugurado em 1995. Pouco tempo depois a rede Marriot adquiriu um terreno localizado na esquina da Rua Guararapes com a Avenida das Nações Unidas, onde deseja construir um hotel de alto padrão.

Atualmente encontra-se em construção o primeiro hotel da rede Hyatt de São Paulo, ao lado da futura sede do Bank Boston e da Rede Globo, com previsão de entrega para o final deste ano. Próximo ao Hyatt está sendo construído o Hilton Morumbi São Paulo, que ocupará a Torre Leste do complexo Centro Empresarial Nações Unidas (CENU), com conclusão prevista para meados de 2002.

Além disso, estão instalados na região inúmeros flats administrados por conhecidas bandeiras como Blve Tree, Sol Meliá, Parthenon, entre outras. 


\section{Principais Atrativos da Região}

Zoneamento A diversidade de zoneamentos na região permitiu o desenvolvimento dos mais diversos tipos de empreendimentos imobiliários nos segmentos de escritórios, comercial (de serviços) e residencial.

Intervenções Urbanas Destacam-se a execução de obras tais como: a abertura da Avenida Água Espraiada; a facilidade de acesso entre as avenidas Engenheiro Luís Carlos Berrini e Nova Faria Lima através da extensão da Rua Funchal; a construção da alça de acesso entre a Ponte Engenheiro Ary Torres e a Avenida Engenheiro Luís Carlos Berrini; a semaforização da avenida; e a implantação das novas estações da Linha Osasco-Jurubatuba da Companhia Paulista de Trens Metropolitanos (CPTM), linha esta que será futuramente integrada à rede metropolitana.

Infra-estrutura de Serviços A implantação de cabeamento de fibra ótica veio atender à demanda do setor de telecomunicações da região.

A região possui ainda uma infra-estrutura que agiliza os negócios e abre espaços para o lazer.

Poder deslocar-se com facilidade para aeroportos ou para qualquer ponto da cidade ou fora dela é, sem dúvida, um fator de grande importância. Além de contar com excelentes vias de acesso, em breve estarão em operação na região da Berrini, o Heliporto Municipal de São Paulo, além da continuação da linha Celeste do metrô.

Além de apresentar variado comércio de rua (lojas, restaurantes e agências bancárias que vieram suprir a demanda gerada pelos escritórios), a região conta também com centros comerciais de grandes dimensões.

O Shopping Morumbi, inaugurado em 1982, foi pioneiro na região. Em 1995 foram concluídos os shoppings temáticos D\&D (voltado para o ramo de decoração e design, faz parte do complexo WTC) e Market Place (lazer). Em 2000 a região inovou com um novo conceito de centro comercial, com a inauguração do Shopping Nações Unidas. Este shopping tem um mix exclusivamente de serviços, voltado para atender à demanda dos escritórios dos complexos CENU (onde está situado) e WTC, bem como dos escritórios situados na sua área de influência.

\section{Tendências}

Mantido o mesmo ritmo de crescimento experimentado na última década e com um estoque de terrenos superior a $350.000 \mathrm{~m}^{2}$, é possível prever que esta ocupação tenha potencial para adicionar cerca de $600.000 \mathrm{~m}^{2}$ úteis de escritórios ao estoque existente. O que, certamente, continuará mantendo o interesse de incorporadores e investidores, com vistas a novos lançamentos para empresas em busca de produtos de alto valor agregado. 
O mapa abaixo dá uma noção estimativa das áreas onde é possível o desenvolvimento imobiliário de edifícios de escritórios. As cores sinalizam os diferentes zoneamentos das quadras, lembrando que terrenos em Zona 2 permitem um coeficiente de aproveitamento equivalente a 1; em Zona $3 \mathrm{e}$ Zona 4, este coeficiente pode chegar a até 4 vezes; e em Zona 6, a 1,5 vez.

\section{TERRENOS INCORPORÁVEIS NA REGIÃO BERRINI}

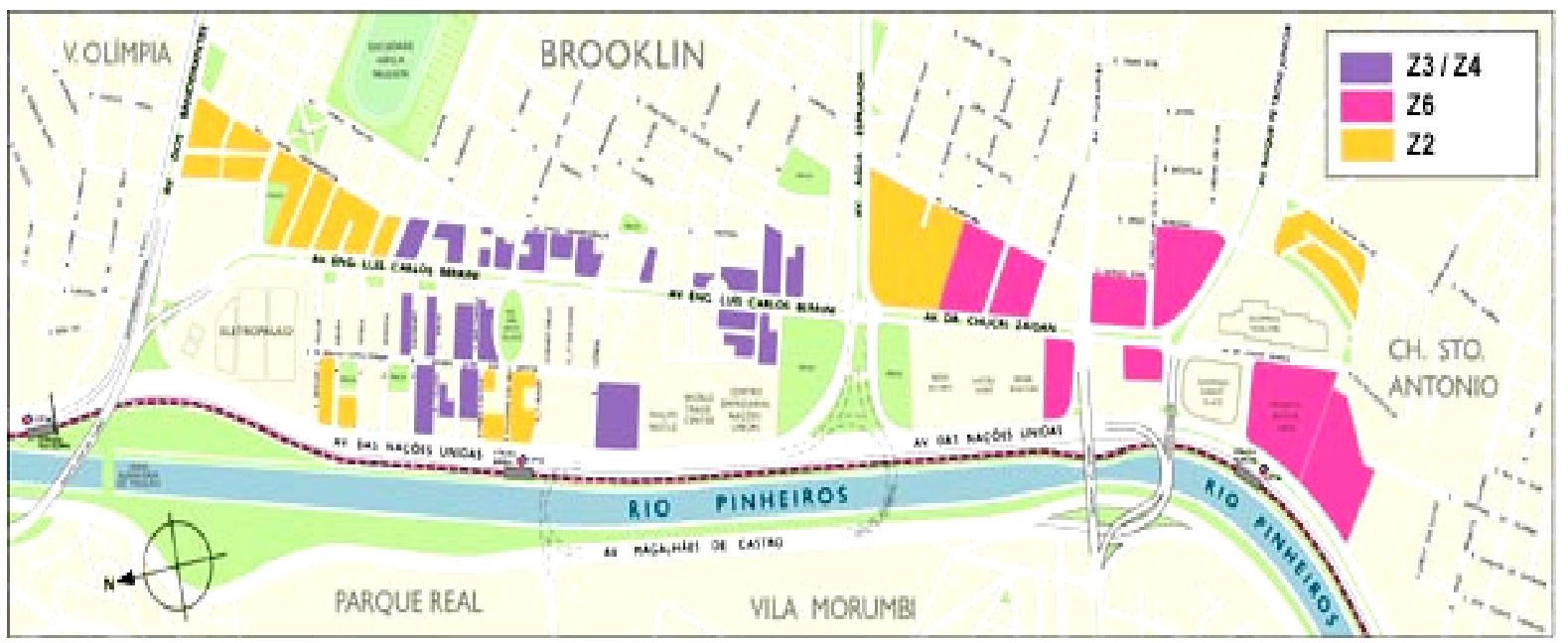

Fig. 66 Terrenos incorporáveis na Berrini

Fonte: http://www.bolsaimoveis.com.br

\section{Necessidade do Projeto Paisagístico}

O Projeto Urbanístico contemporâneo também deve levar em conta as características da Paisagem e do Meio Ambiente e existe a tendência do paisagismo se constituir em um projeto separado.

Tal prática tem encontrado forte aceitação no panorama Urbanístico brasileiro, que possui na figura de Burle Marx, o grande mestre do paisagismo no Brasil, pioneiro no desenvolvimento explorando cores e texturas de plantas tropicais desconhecidas e pouco usadas na época.

As pessoas vivem dentro de espaços cada vez menores e por isso há a necessidade de se criar mais áreas de lazer. O ser humano necessita de natureza para viver.

O mercado do paisagismo atualmente está em expansão. A criação de grandes áreas de lazer é um exemplo disso. Há dez anos, ninguém ia aos parques, enquanto que hoje inúmeros cidadãos utilizam os espaços ao ar livre para o seu lazer, fazer caminhadas e relaxar.

Há ainda o paisagismo direcionado ao entorno dos prédios, às residências e aos condomínios horizontais. Intensifica-se também a construção de terraços, hoje muito utilizados. No Brasil, como em outros países, existe a necessidade de áreas para a absorção de água, porque o solo está cada vez mais impermeável. Os terraços servem também para embelezamento e lazer das 
pessoas que ali moram e também para a qualidade de vida das grandes cidades. Há outro campo aberto que é do micro paisagismo em interiores, que trabalha em micro escalas. Este trabalho representa um campo maior de atuação, já que os projetos de grandes espaços não surgem todo o dia.

As incorporadoras e construtoras estão inserindo cada vez mais Arquitetura paisagista em seus projetos. Paisagismo virou sinônimo de vendas. Hoje, todos os empreendimentos lançados têm área de lazer, com churrasqueira, piscina, campos de esporte como formas de atrair os compradores. A importância do profissional paisagista cresceu tanto que atualmente as incorporadoras o procuram antes para estudar a colocação dos prédios. Dependendo da área do conjunto, o paisagista faz com que sobrem mais espaços, ambientes mais ensolarados, resultando na valorização do produto.

O arquiteto tende a usar a vegetação como um elemento decorativo, principalmente quando é uma Arquitetura ligada à decoração. Em relação aos modismos, já vivemos a época das samambaias e das palmeiras. Agora é a vez dos cactus, lança de ogum, procurando sempre o exotismo.

A conservação é essencial num projeto. Se não houver uma boa conservação, a vegetação morre. Nas fábricas, a vegetação é mais rústica, e o volume é maior porque geralmente são áreas maiores para terem sucesso e durabilidade. Cada programa é diferenciado.

A iluminação qualificou-se e otimiza o segmento de paisagismo. É um fator essencial e transforma muitos projetos em verdadeiras obras de arte. $O$ sistema de irrigação também está bastante desenvolvido para áreas maiores como em condomínios.

A vizinhança é outro fator levado em consideração pelos paisagistas na hora de desenvolver um projeto. Preservar as árvores locais e plantar algumas nas calçadas minimiza o impacto ambiental da construção, além de proporcionar uma área agradável e prazerosa aos moradores. 


\section{Aspectos Projetuais e Construtivos para abrigar a Alta Tecnologia - Casos}

Neste capítulo daremos um enfoque especial à produção recente de obras de grande porte. Assim foi necessário definir o que consideramos um grande 
escritório, para poder então enfrentar a dificuldade de conceituar o que seria uma obra de grande porte.

Não se trata de selecionar apenas pela região onde estes prédios estão inseridos, nem somente pelo tamanho da obra. Foram também considerados aspectos como a complexidade do programa, a atualidade dos materiais e tecnologias utilizadas, a eficiência, a rapidez e competência com que estes grandes (e também médios e pequenos) escritórios de Arquitetura utilizaram. Uma ousadia diante do conservadorismo que ainda paira sobre este mercado, que visa um retorno financeiro seguro e não aceita mudanças radicais na questão arquitetônica e urbana.

Do acervo da produção recente, daremos enfoque especial a quatro escritórios, onde foram escolhidos basicamente edifícios de escritórios, embora se observe a existência desta tecnologia em edifícios multifuncionais, direcionados a habitação, entretenimento lazer, etc. Alguns são conjuntos complexos enquanto projeto e construção. Outros são torres isoladas. Todos são significativos na paisagem urbana onde estão inseridos: a marginal Pinheiros.

A dimensão destas obras desenvolvida por estes escritórios não é a mais comum, que atualmente estão atentos e empenhados em atendimentos mais pontuais e limitados. Obras de grande porte são exceções num mercado relativamente restrito, embora potencialmente amplo.

Sobre a metodologia da pesquisa de dados e da redação dos resultados e as dificuldades encontradas podemos citar:

1. Fontes documentais - documentação fornecida pelas construtoras, revistas técnicas (material mais rico), fotos (quando não tive acesso, apenas registrado o exterior);

2. Visita in loco - WTC-SP e CENU, nos outros edifícios foram encontradas dificuldades na realização de contatos, pois as empresas não responderam às cartas de solicitação de visitas;

3. Entrevistas - foram entrevistados os arquitetos do escritório Botti e Rubin, profissionais da área de mobiliário de escritórios, engenheiros responsáveis pela administração predial e alguns consultores da área de investimentos imobiliários;

4. Para cada edifício são apresentados dados básicos, o partido arquitetônico e uma primeira síntese das principais tecnologias utilizadas;

5. No último edifício apresentado, o CENU, são relatados maiores detalhes dos sistemas tecnológicos, devido a sua complexidade (três torres, centro de convenções, centro comercial, e estacionamento), por apresentar tecnologias evolutivas diferenciadas em cada momento da execução e também por facilidade de acesso ao edifício.

\subsection{World Trade Center - SP}


Situado na região da avenida Luís Carlos Berrini, o conjunto World Trade Center São Paulo (WTC), por suas dimensões e complexidade, é uma obra notável. Embora não se destaque como um marco de qualidade arquitetônica atingida em outras obras do escritório Aflalo \& Gasperini, como o edifício Citibank, na avenida Paulista. O WTC finaliza um longo processo de quase duas décadas de elaboração de projetos e programas para aquele local, e cujo estudo pormenorizado permitiria uma compreensão mais clara da produção recente de edifícios empresariais em São Paulo.

A ausência de um maior diálogo urbano, característica muito presente nas grandes cidades latino-americanas, pode ser computada em grande parte ao estado de inacabamento de toda a região da Berrini, cuja transformação em centro de negócios continua a ser feita lote a lote, sem a necessária visão de conjunto que poderia qualificar o espaço urbano de maneira mais digna. No caso do WTC, isso se deu parcialmente a revelia das intenções iniciais

empreendimento, pensado a partir de meados dos anos 70 como a urbanização de uma gleba bem maior, hoje desmembrada, englobando a área do edifício Nestlé e do Centro Empresarial Nações Unidas.

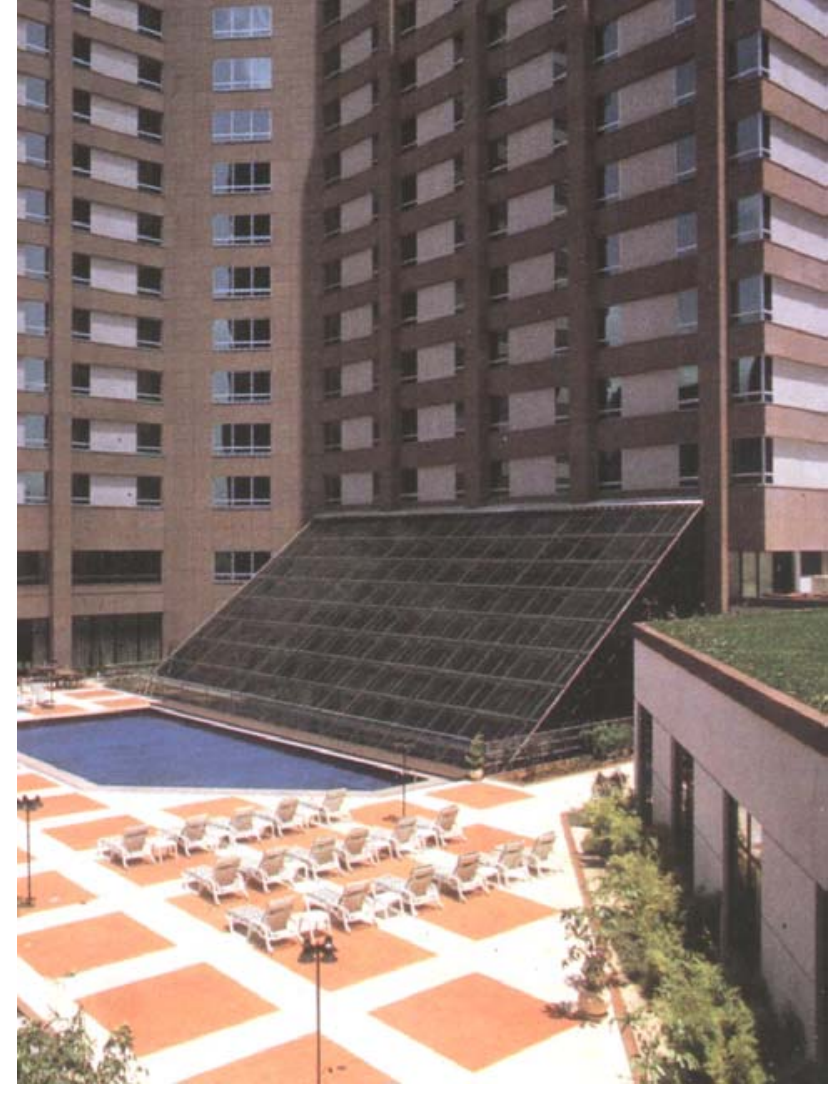

Fig. 67 Área externa do Hotel Fonte: Revista Projeto Design no 193 jan/fev 96

O conjunto do WTC pode ser visto como uma solução arquitetônica em sinergia: não é apenas uma torre de escritórios, um shopping, um hotel, um centro de convenções e exposições, uma garagem para mais de 2 mil vagas, nem é a simples agregação de tudo isso, mas transcende seu somatório numa resultante "sinergética". O projeto realizado nasceu da interpretação arquitetônica desse amplo programa, novo no Brasil, embora testado em outros pontos do planeta com variações.

O desenho externo da torre dá prosseguimento aos exercícios formais dos autores com o tema das grelhas, com um grau de abstração plástica que já se anunciava no edifício Nestlé e que aqui se intensifica. Embora a solução ainda se filie à tradição paulista de protagonização da estrutura na resolução formal do edifício, esta obra se aproxima, sem subordinação, da solução formal de contraposição entre a estrutura interna e a pele externa. 


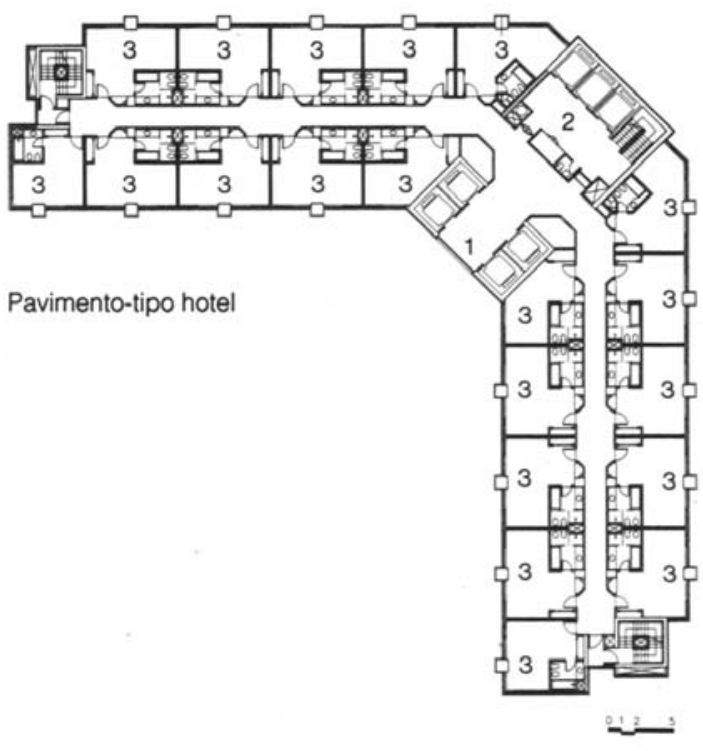

A volumetria em "L" e o gabarito mais baixo do hotel, visam diferenciá-lo da torre de escritórios, enfatizando um caráter residencial que, junto com o relativo afastamento entre ambos, cria a sensação urbana de se tratar de outro empreendimento. Embora se desejasse certo grau de diferença, essa resultou em alguma dissonância, sobretudo devido ao tratamento dado às fachadas do hotel - cuja execução difere da proposta dos autores.

Fig. 68 Planta do pavimento tipo do hotel Fonte: Revista Projeto Design no 193 jan/fev 96

O shopping acompanha as pautas comuns a esse tipo de programa, apresentando-se externamente muito fechado, usando o vidro nas fachadas por suas qualidades como revestimento e para sugerir leveza. O WTC, em sua Arquitetura, define uma solução eficiente e de alta complexidade, resultado decantado de uma longa experiência profissional genuinamente brasileira.

O projeto do WTC teve uma longa e variada gestação, acompanhando as alterações de terreno e de conceito de seus promotores, ao longo de mais de uma década. A última e definitiva versão, entretanto, foi projetada e realizada em tempo relativamente rápido, se considerado o porte da obra. Isso implicou a simultaneidade entre certas fases do projeto e da obra, a dispersão parcial das atribuições de complementação e detalhamento e certo grau de adaptações, basicamente nos detalhes e no uso de materiais de acabamento. A concepção geral, no entanto, se manteve íntegra.

\section{Partido Arquitetônico}

Fig. 69 Planta da Torre de Escritórios

Fonte: Revista Projeto Design no 193 jan/fev 96

0 projeto nasceu de baixo para cima, ou ainda, da modulação para a modelagem dos espaços. Partiu-se de uma malha de $10 \times 10 \mathrm{~m}$, varrendo todo o terreno, criando eixos imaginários dispostos no

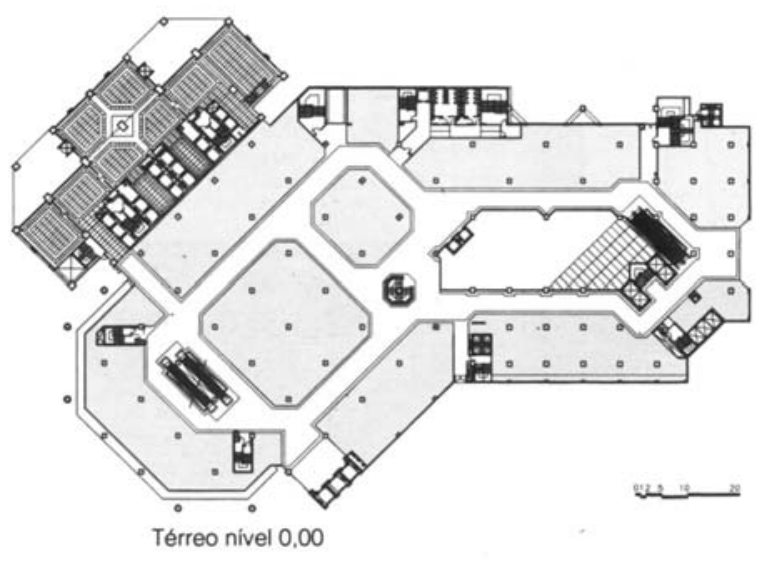
sentido dos pontos cardeais, mas em $45^{\circ} \mathrm{em}$ relação às divisas do lote retangular quase regular. Na faixa junto á marginal do Rio Pinheiros os volumes se dispõem segundo essa rotação, enquanto na metade oposta, paralela e mais próxima da avenida Luís Carlos Berrini, os volumes sofrem 
rotação de 450, resultando em paralelos aos alinhamentos. Esse jogo dá as regras para a apropriação do amplo lote disponível.

Atendendo os recuos legais, é seguida uma lógica própria de projeto que serve de apoio racional para a disposição das edificações que compõem o conjunto, além de simplificar a disposição das vagas de autos nos subsolos destinados a garagens. A essas vantagens construtivas iniciais soma-se a possibilidade de potencializar um diálogo com a vizinha torre da Nestlé, dos mesmos autores, de garantir afastamento da via de tráfego rápido e de proximidade do pólo de atração de pessoas e veículos em baixa velocidade vindos da Berrini.

Os volumes resultantes se justapõem, ocupando a área legalmente disponível, que varia em função da cota. A solução resultante é ainda a de placa/torre: torres de diferentes alturas 126 pisos para os escritórios, 16 para o hotel e 3 pisos para shopping/convenções) sobre um grande embasamento.

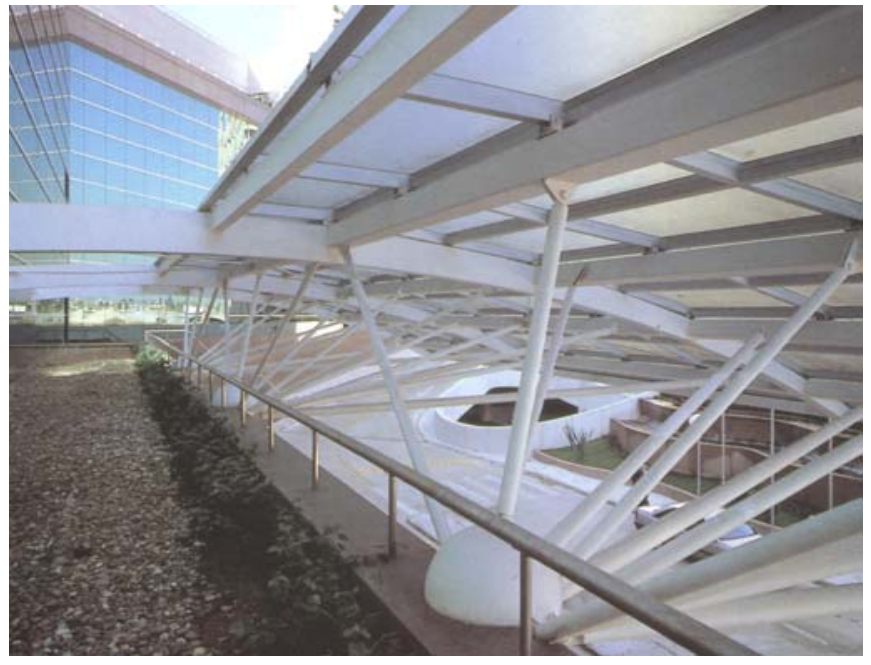

Fig. 70 Detalhe da treliça espacial metálica Fonte: Revista Projeto Design no 193 jan/fev 96

A disposição das funções nos volumes não é estanque, tanto em planta como em elevação, havendo razoável grau de interpenetração entre ambientes de características e usos distintos. Apesar da fluidez de circulação entre as várias atividades, sua relativa autonomia fica garantida tanto pela existência de acessos independentes como pela possibilidade de eventual isolamento, quando necessário, de determinadas porções do conjunto, além da presença de alguns elementos invariáveis que balizam e definem as áreas alocadas aos diferentes usos.

Fundada nos Estados Unidos em 1970 para promover o comércio internacional, a World Trade Centers Association se espalha hoje por mais de 89 países e reúne cerca de 500 mil empresas filiadas no mundo inteiro. Afirmativas e onipotentes chamadas, pelo guia nova-iorquino AIA - American Institute of Architects de "monolitos banais", as "Twin Towers" de M. Yamasaki, dominaram até pouco tempo com seus 110 pavimentos o perfil de Manhattan.

Mesmo com diferenças claras no programa, que respondem basicamente a adaptações a demanda local, a concepção do empreendimento é a mesma nas suas 259 unidades atuais: centros empresariais ambiciosos, com características multiuso, aproveitando a sinergia entre áreas diversas para apoiar a realização de negócios internacionais. Para promover o acesso dos seus associados - em grande parte pequenas e médias empresas - ao mercado internacional, todas as unidades do WTC são também dotadas de 
sistemas de comunicação e recursos de automação predial de ponta. Neste caso, a operação envolve como principais atores 33 fundos de pensão, que se organizaram em cotas na expectativa de que o investimento inicial seja amortizado em menos de uma década.

A robusta torre com 26 andares e $29 \mathrm{mil} \mathrm{m}^{2}$ de área útil abriga um clube internacional de negócios, áreas de exposição de produtos e escritórios para locação. Os três primeiros andares são dedicados ao chamado "Business Club", um núcleo aberto a todos os associados, com salas de trabalho para executivos em trânsito, biblioteca, restaurante e espaços para treinamento e conferências. Do $4^{\circ}$ ao $14^{\circ}$ pavimento foram instalados show-rooms e vitrines para exposição permanente e temporária de produtos e serviços relativos ao comércio exterior. Os pavimentos superiores, destinados a escritórios para locação, têm espaços moduláveis entre $46 \mathrm{~m}^{2}$ e $1.218 \mathrm{~m}^{2}$, divididos por painéis de gesso com revestimento acústico.

O pavimento-tipo tem serviços e equipamentos concentrados na fachada posterior, com duas baterias de sanitários e dois halls com dez elevadores, que operam pelo sistema de zoneamento. Às escadas só se tem acesso em caso de incêndio.

Para facilitar o arranjo dos espaços internos, as instalações elétricas e de telefonia correm em canaletas de piso, também obedecendo ao módulo básico de 1,25m x 1,25m, que regula todo o edifício.

A estrutura é basicamente definida pelo grande pilar de concreto do corpo central associado às lajes executadas com sistema de "mesas voadoras", o que possibilitou a concretagem de cada laje de 1,7 mil $\mathrm{m}^{2}$ em sete dias.

Fig. 71 Grelhas da fachada da torre de escritórios Fonte: Rev. Projeto Design no 193 jan/fev 96

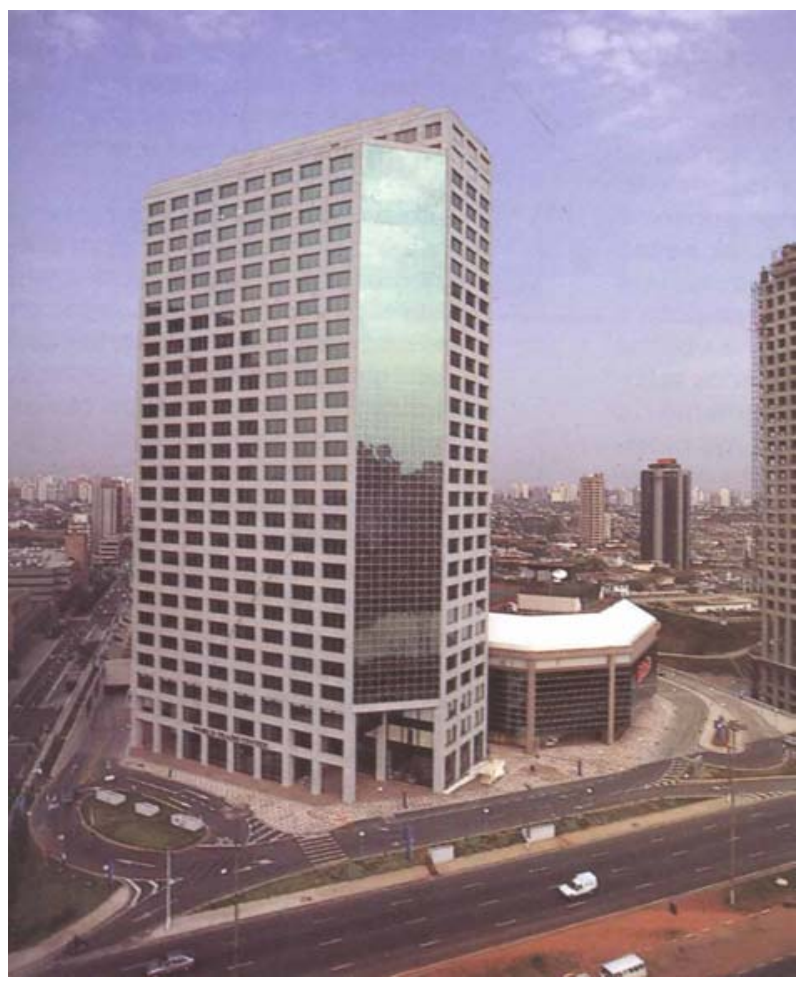

Nas fachadas, a idéia das grelhas estruturais, revestidas com placas de granito e fixadas com grampos de aço inox e valorizada como linguagem arquitetônica, se repete, mas desta vez a solução faz pensar num apego a forma, que reduz o vigor do conceito original. Examinando ainda as fachadas, percebe-se que o ritmo dos pilares que as configura escapa do conceito estrutural, havendo intenção de o edifício vizinho, projetado anteriorm
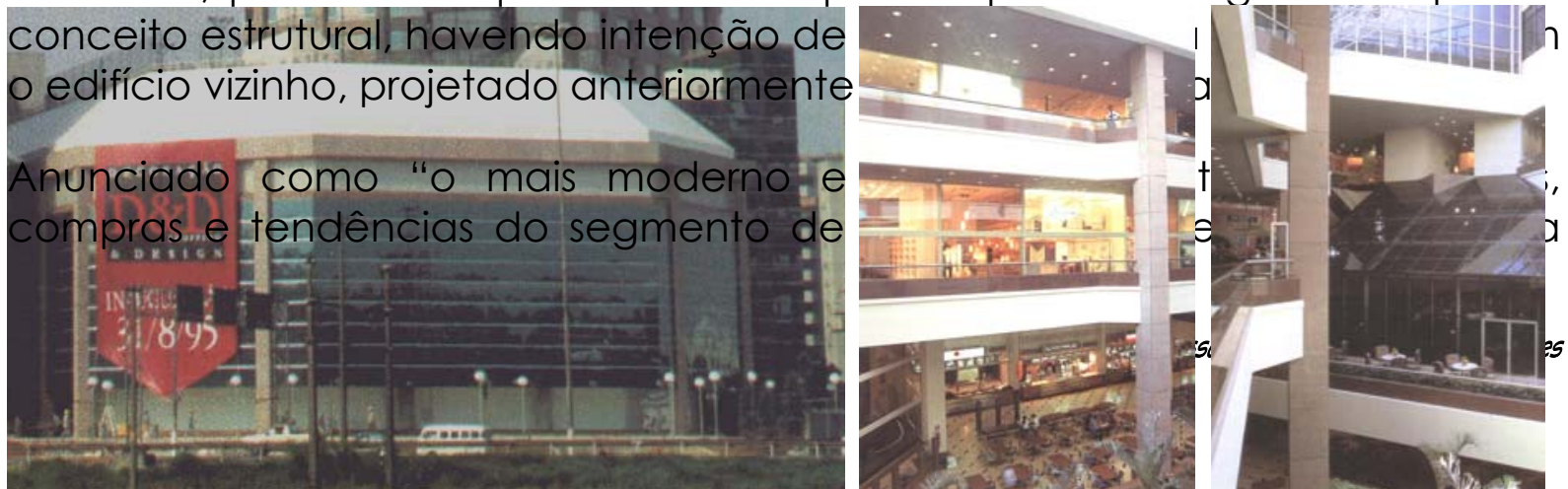
Latina", O shopping D\&D - Decoração \& Design, pretende atrair consumidores e profissionais de cidades e regiões vizinhas, com interesse especial pelos países que compõem o Mercosul. São 120 lojas especializadas e 40 no setor de alimentação e serviços voltados ao consumidor direto e aos profissionais da área. O shopping, com área locável de $12 \mathrm{mil} \mathrm{m}^{2}$, tem três níveis de lojas e é coroado por um terraço (com duas quadras de tênis, uma de "paddle" e pista de Cooper), ligado à torre do hotel anexo.

Fig. 72 Shopping D\&D - WTC-SP

Fig. 73 Interior do Shopping 1

Fig. 74 Interior do Shopping 2

Fonte: Arquivo Pessoal

O complexo conta ainda com hotel cinco estrelas de 300 suítes e um centro de convenções administrado pelo grupo Sol, empresa espanhola reconhecida no setor hoteleiro pela bandeira Meliá. O hotel é dirigido ao segmento de negócios e procura privilegiar os espaços destinados aos hóspedes, condensando as áreas de serviço. Cada suíte padrão tem aproximadamente $40 \mathrm{~m}^{2}$, dentro dos princípios e especificações estabelecidos pela Meliá. Todas têm sistema de ar-condicionado com controle individual, duas linhas de telefone, fax, microcomputador e TV.

Fig. 75 Torre do Hotel- WTC-SP

Fonte: Revista Projeto Design no 193 jan/fev 96

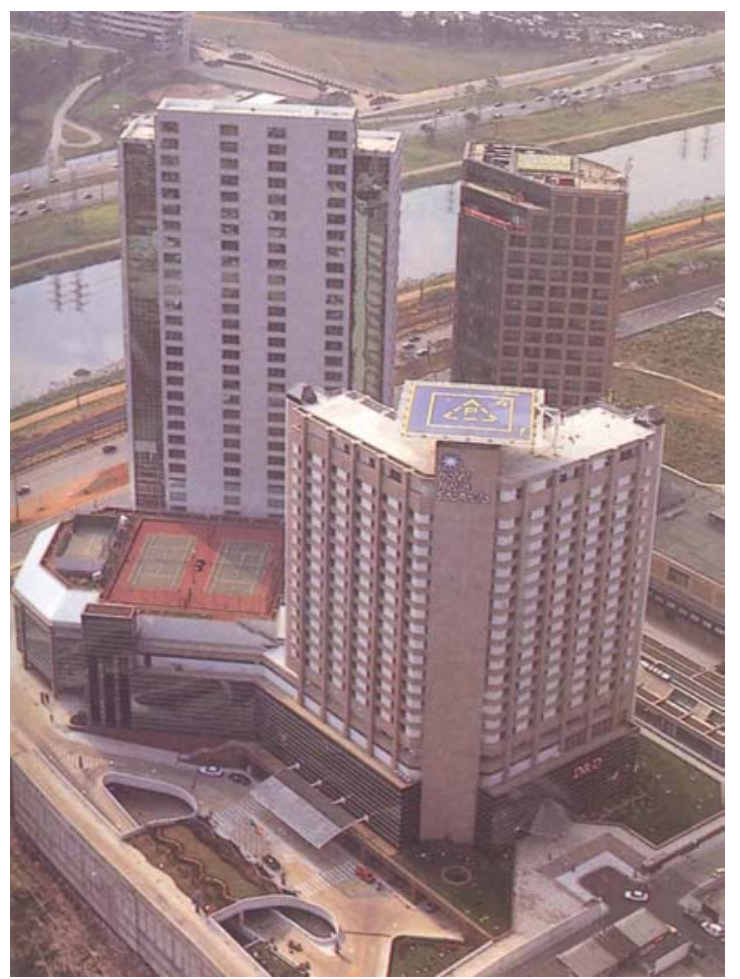

No primeiro pavimento foram instaladas seis suítes especialmente projetadas para atender aos hóspedes com deficiência física. Nos três últimos níveis, o serviço real, 40 suítes VIP's, mais 2 presidenciais e 4 duplas, com recepção, área social e serviços exclusivos.

O centro de convenções, com cerca de 5 mil $\mathrm{m}^{2}$, tem como atração um auditório de 545 lugares e uma área de eventos de $928 \mathrm{~m}^{2}$, que pode ser dividida em quatro espaços, por meio de divisórias recolhidas nos pilares, ou comportar a montagem de um anfiteatro para 1200 pessoas. Além disso, conta com duas salas de videoconferência e áreas de apoio. Embora integrado ao hotel e ao shopping, o centro tem acesso privativo por três elevadores panorâmicos. É servido também por um

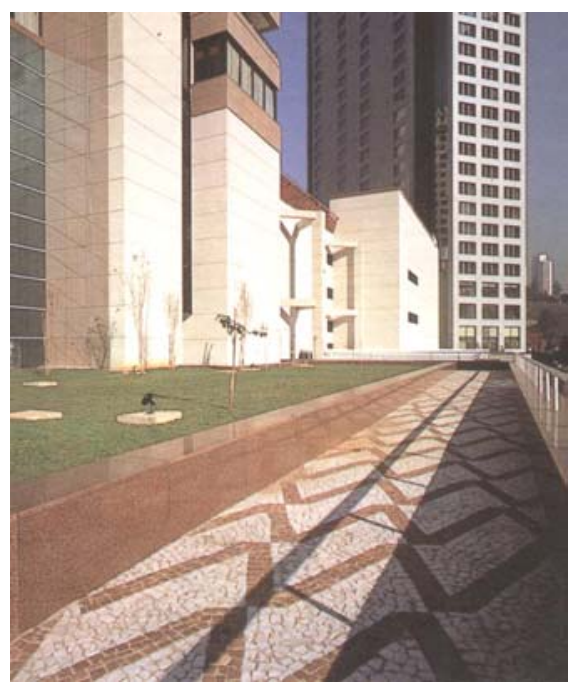


elevador de grande potência, capaz de transportar veículos.

Fig. 76 Área externa entre o complexo Fonte: Revista Projeto Design no 193 jan/fev 96

\section{Tecnologias Utilizadas}

Em termos de infra-estrutura de apoio, o complexo reúne requintes de alta tecnologia e oferece os serviços mais avançados de automação predial.

O centro de convenções e a torre de escritórios são dotados de uma espinha dorsal de fibras ópticas - conhecida como backbone - para transmissão de dados e imagens entre computadores geograficamente distantes, de acordo com o nível mais veloz de tráfico de dados (nível 5).

Pelo sistema de rede comercial exclusiva, interligada à Internet, veicula em tempo real catálogos e informações sobre compra e venda de produtos a banco de dados de 160 países e mais de 500 mil empresas. Outro serviço disponível é a videoconferência, que permite a apresentação simultânea de produtos a todos os WTC's, via satélite.

Através de circuito fechado de TV, também é possível aos hóspedes do hotel acompanharem os eventos realizados no centro de convenções.

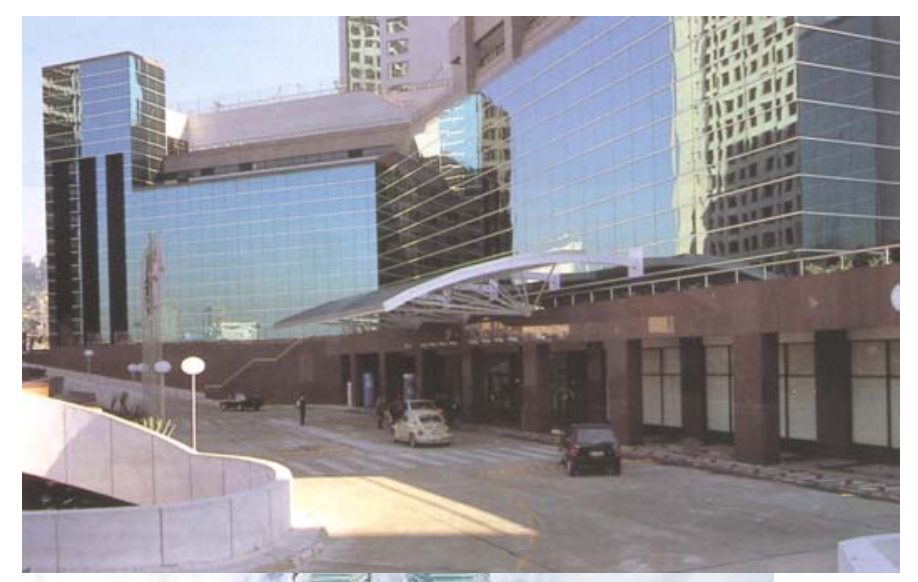

O estacionamento, comum a todo o conjunto, acomoda 2.100 vagas em cinco subsolos, com folga de cerca de 600 vagas em relação aos limites estabelecidos pela legislação. $\mathrm{Na}$ cobertura do hotel, um heliponto tem capacidade para atender a helicópteros de grande porte, com até 14 passageiros.

Fig. 77 Torre do Hotel- WTC-SP

Fonte: Revista Projeto Design no 193 jan/fev 96

\subsection{Plaza Centenário}

Com ampla experiência no projeto de escritórios, Carlos Bratke é o autor da maioria dos edifícios na área da avenida Luiz 
Carlos Berrini, onde também se localiza sua obra mais recente e de maior porte que até hoje realizou: o edifício Plaza Centenário. Nela o autor inicia uma nova abordagem, marcada pela ampla utilização de placas de alumínio, cujas características estruturais permitem grande liberdade na criação de formas. Mas seu emprego não se limita a exploração do aspecto plástico e estético, mas influencia diretamente no processo construtivo, substituindo materiais mais tradicionais e tornando a construção mais limpa e seca, como uma montagem. Com isso, ganha-se em eficiência, embora seja necessário investir na mudança de mentalidade dos executores.

Fig. 78 Vista da torre

Fig. 79 Detalhe da torre - revestimento de alumínio

Fonte: Revista Projeto Design no 193 jan/fev 96

O Plaza Centenário demonstra a simpatia do autor pelo caminho de maior arrojo tecnológico, que considera adequado ao projeto de edifícios de grande altura, soltos no terreno e marcantes na paisagem urbana, aproximando-se da chamada Arquitetura high-tech.

Embora a maioria dos autores de edifícios altos opte por plantas que tendem ao quadrado, com core central de circulação e serviços, Bratke tem preferido soluções mais longitudinais. De qualquer maneira, ele afirma que o mais importante é que as soluções de circulação vertical aconteçam de maneira mais compacta, permitindo menor perda de espaço em área comum e conseqüentemente aumentando a área útil. Verificou também que os halls, que costumam ser pequenos, precisam de mais espaço, por receberem um grande fluxo de pessoas, constituindo-se ainda em um local de espera. As novas exigências que vem sendo feita são os locais para lojas no térreo. Na região da Berrini, anteriormente esse pavimento destinava-se a estacionamento, evitando a existência de vários subsolos, pois a tecnologia para realizá-los era muito onerosa.

A localização do Plaza Centenário, junto à avenida marginal do rio Pinheiros, uma via de alta velocidade, Ihe dá uma situação urbana diferenciada dos edifícios da avenida Berrini, que estão para ele como um pano de fundo. A ampla várzea do rio cria um vazio na sua frente, acentuando seu caráter monumental, que os reflexos prateados e a aparência de imenso maquinismo estático só fazem reforçar.

\section{Partido Arquitetônico}

O terreno onde se localiza o Plaza Centenário já possuía um edifício de baixa altura e com grande ocupação do terreno. Isso colocou problemas quanto à melhor forma de aproveitamento do lote restante. Havia duas soluções possíveis: ou se faziam dois prédios baixos - um atrás da edificação existente e outro no local em que foi erguido o Plaza Centenário - ou apenas um muito alto. Os empreendedores optaram pela segunda, embora fosse a mais cara, seria a mais imponente. 
O edifício está apoiado em quatro torres e oito pilares. Em geral, a estrutura dos edifícios muito altos é metálica. Nela não se emprega concreto porque este exige pilares de grandes dimensões nos andares mais baixos. Para evitar esse problema, a solução proposta para a seção dos apoios foi manter sua largura constante, enquanto o comprimento, maior nos subsolos, vai diminuindo nos andares superiores. As quatro torres funcionam como pilares externos ocos, abrigando instalações e sanitários, conformando pórticos que ajudam na resistência aos esforços produzidos pela ação do vento.

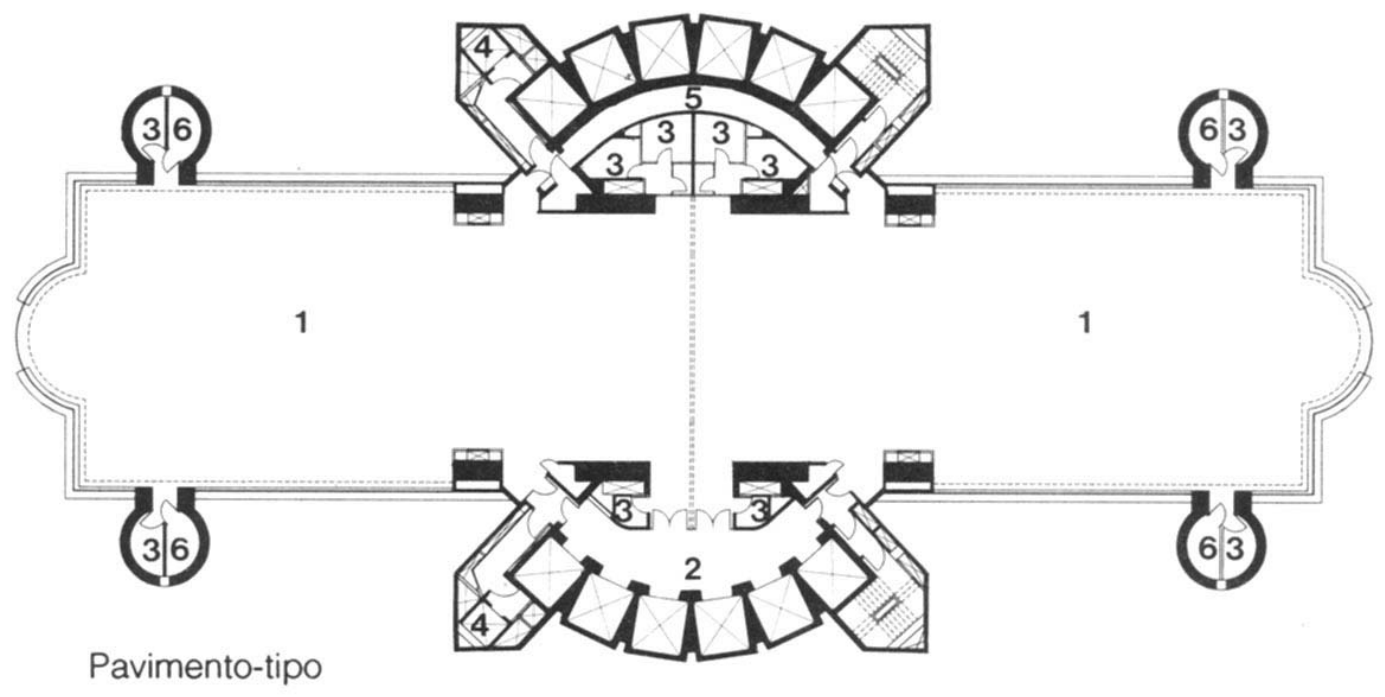

Fig. 80 Planta do pavimento tipo

Fonte: Revista Projeto Design no 193 jan/fev 96

O Plaza Centenário apresenta as mesmas características de distribuição de espaços em planta dos demais edifícios realizados pelo autor na região da Berrini: elevadores como volumes externos, sombreando parcialmente as fachadas e salão sem colunas intermediárias, com comprimento maior que a largura, facilitando a disposição do mobiliário e proporcionando melhor iluminação natural.

Para economizar na altura dos pés-direitos dos andares-tipo, as instalações elétricas, de ar-condicionado e sprinklers foram encaixadas nos espaços entre as vigas. A viga de bordo ficou externa à área útil do pavimento, de maneira a localizar o duto principal de ar-condicionado na periferia e os secundários (ramais) entre as vigas. No projeto original, o forro também era colocado apenas entre as vigas, deixando algumas faixas em concreto aparente, para economizar pé-direito por motivos estéticos. Entretanto acabou sendo executado um forro, comum, encostado. Também para diminuir as alturas não foram empregados pisos elevados, e sim um sistema de canaletas, apesar do custo mais alto. Para a proteção contra a incidência solar foram utilizados vidros reflexivos, recuados da fachada para garantir certo grau de sombreamento, proporcionando economia no arcondicionado. 


\section{Tecnologias Utilizadas}

Buscou-se utilizar a experiência de alta tecnologia de construção, adaptando-a ao orçamento e ao clima brasileiro. O sistema de segurança contra incêndio, segurança patrimonial e automação é bastante sofisticado, seguindo os mais recentes padrões em edifícios desse tipo.

A Construtora Cetenco Engenharia dedicou atenção especial à execução dos seis subsolos de estacionamento, já que as sondagens do terreno identificaram a presença de lençol freático e de rocha a pouca profundidade. Uma parede diafragma moldada in loco, ao longo de todo o perímetro do terreno com espessura nominal de $40 \mathrm{~cm}$, fez a contenção lateral da área escavada. As fundações da torre foram resolvidas através de seis sapatas (duas delas de grandes dimensões) apoiadas diretamente sobre a rocha. Para agilizar a obra, optou-se pela concretagem independente e simultânea dos pilares e lajes.

Há dois elevadores para bombeiros, com antecâmara pressurizada, e que podem ser usados para carga. Esse tipo de elevador é exigido em prédios com mais de $80 \mathrm{~m}$ de altura, superiores, portanto, ao alcance da escada. Ele possui um gerador próprio e funciona independentemente da energia do edifício. Há um sistema de alarme automático, que avisa onde está ocorrendo o incêndio e indica, em cada andar, a rota de saída.

Os custos foram elevados não apenas pelo emprego de placas metálicas e pelos cuidados com segurança (acentuados por se tratar de um edifício muito alto), mas também pelo uso de elevadores sociais sofisticados, pelos grandes vãos e pelos seis subsolos em terreno com grandes matacões, que exigiram emprego de dinamite.

No primeiro subsolo ficam equipamentos sofisticados, e os outros se destinam a estacionamento. Há ainda elevador para manobristas e um elevador externo para um futuro restaurante no mezanino do prédio.

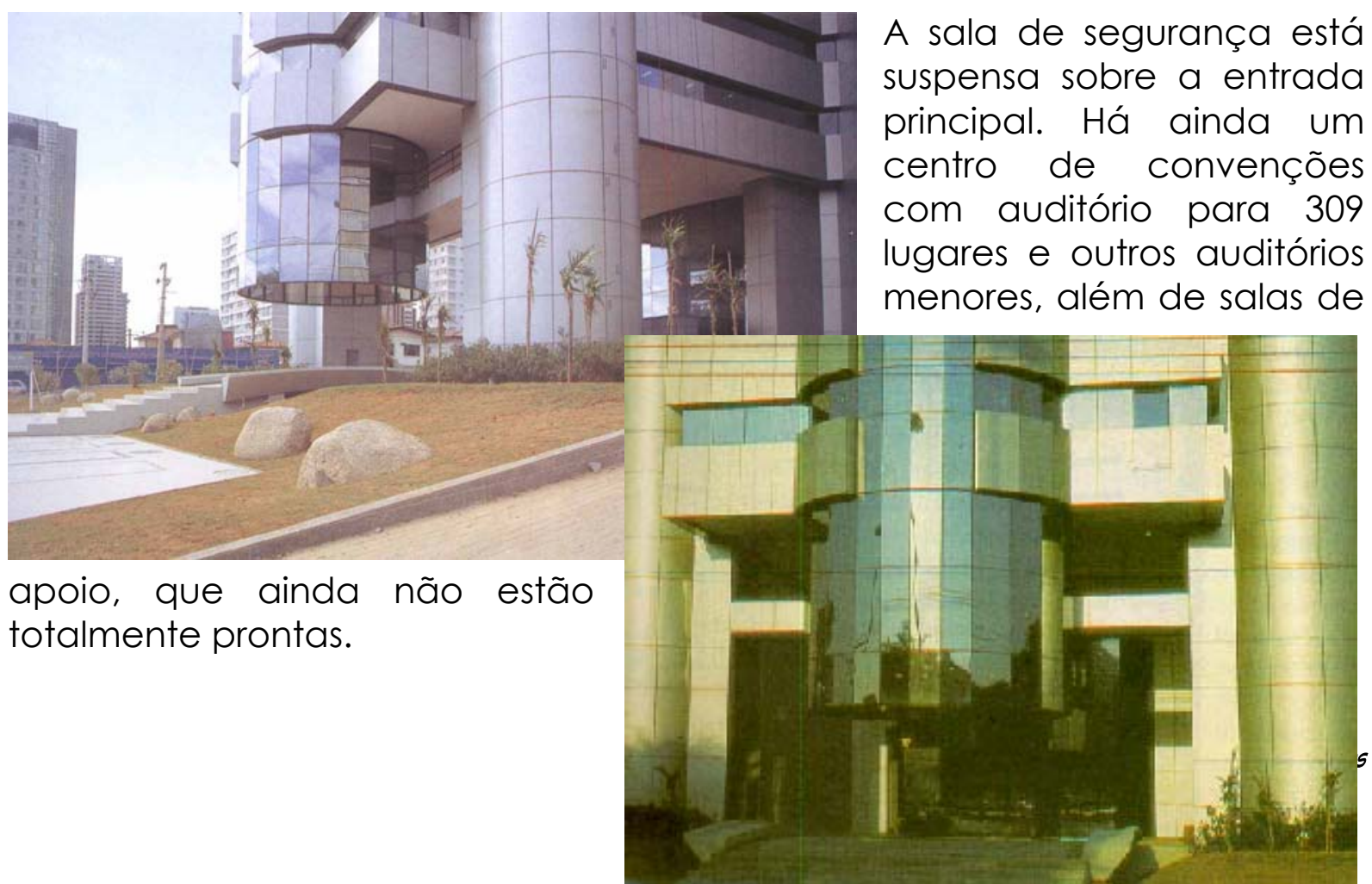


Fig. 81 Sala de controles

Fig. 82 Sala de controles

Fonte: Arquivo Pessoal

O sistema operacional, que inclui automação e segurança integrada, está centralizado na sala de comando, no térreo, junto ao acesso principal. Além de catracas para triagem de pessoal no hall principal e no subsolo, funcionando por cartão de proximidade, o sistema dispõe de 6 mil pontos de automação predial e 3 mil pontos de combate e prevenção de incêndio, como detectores de fumaça e alarmes. Através do sistema hot line, é também possível a comunicação direta entre quaisquer pontos do prédio, por interfone.

Para a circulação vertical, a torre conta com 12 elevadores de alta velocidade, programáveis. A novidade do sistema importado pela Vilares é um dispositivo que armazena dados semanais sobre as operações desses equipamentos em uma memória eletrônica de forma que seu funcionamento obedece a rotina dos usuários. Além disso, foram instalados um elevador panorâmico para acesso ao restaurante, dois de segurança que servem a todos os pavimentos e mais dois especiais para manobristas que operam o estacionamento (com 872 vagas rotativas em cada subsolo). A cobertura é coroada por heliponto, dimensionado para receber helicópteros de grande porte.

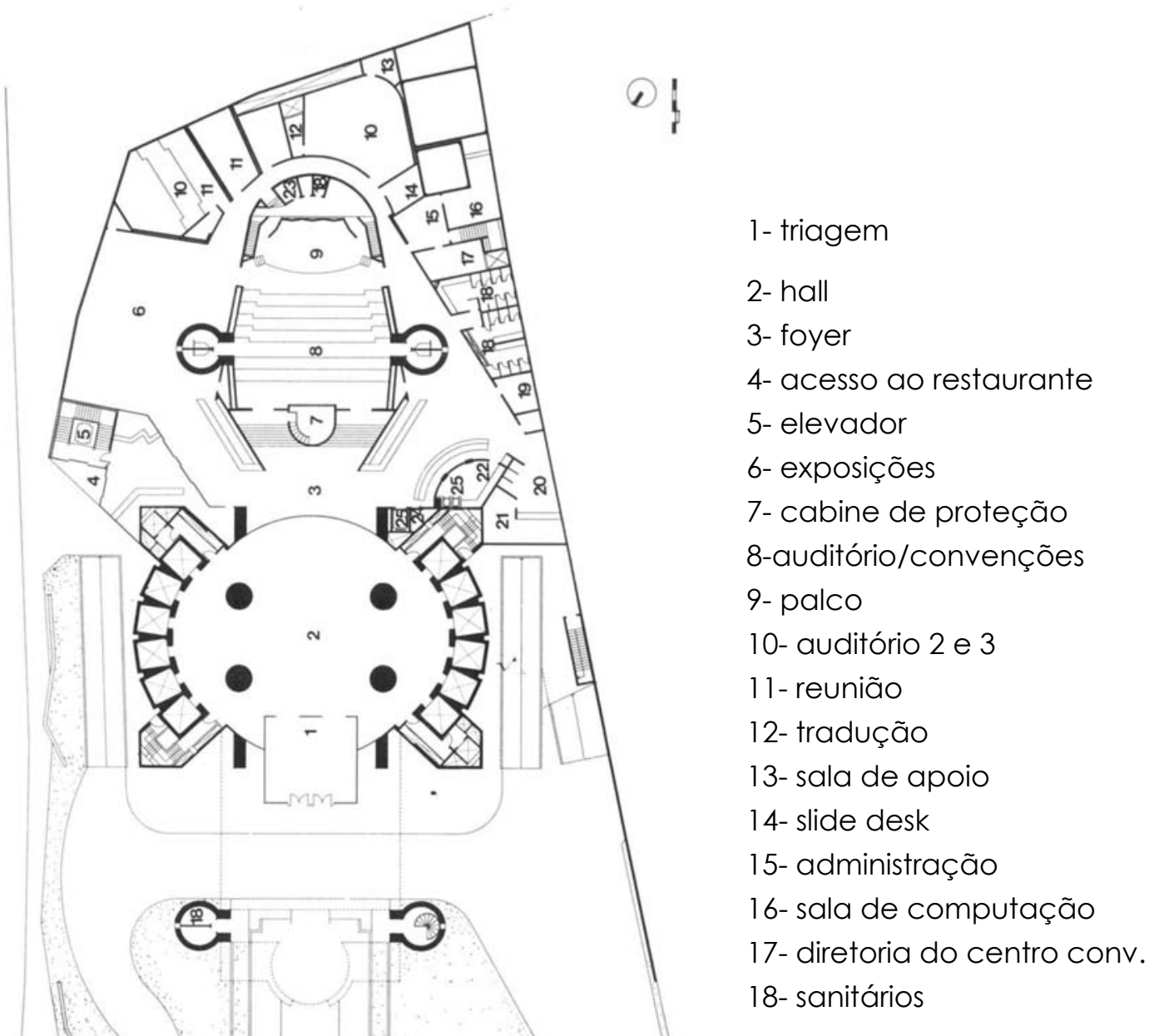

Raissa Pereira Alves de Azevêdo Neves 
19- serviço médico

20- telefone/xerox

21- serviço de imprensa

22- lanchonete

23- copa

24- sala de comando

25- monta-cargas

Fig. 83 Planta do térreo

Fig. 84 Planta do Mezanino

Fonte: Revista Projeto Design no 193 jan/fev 96

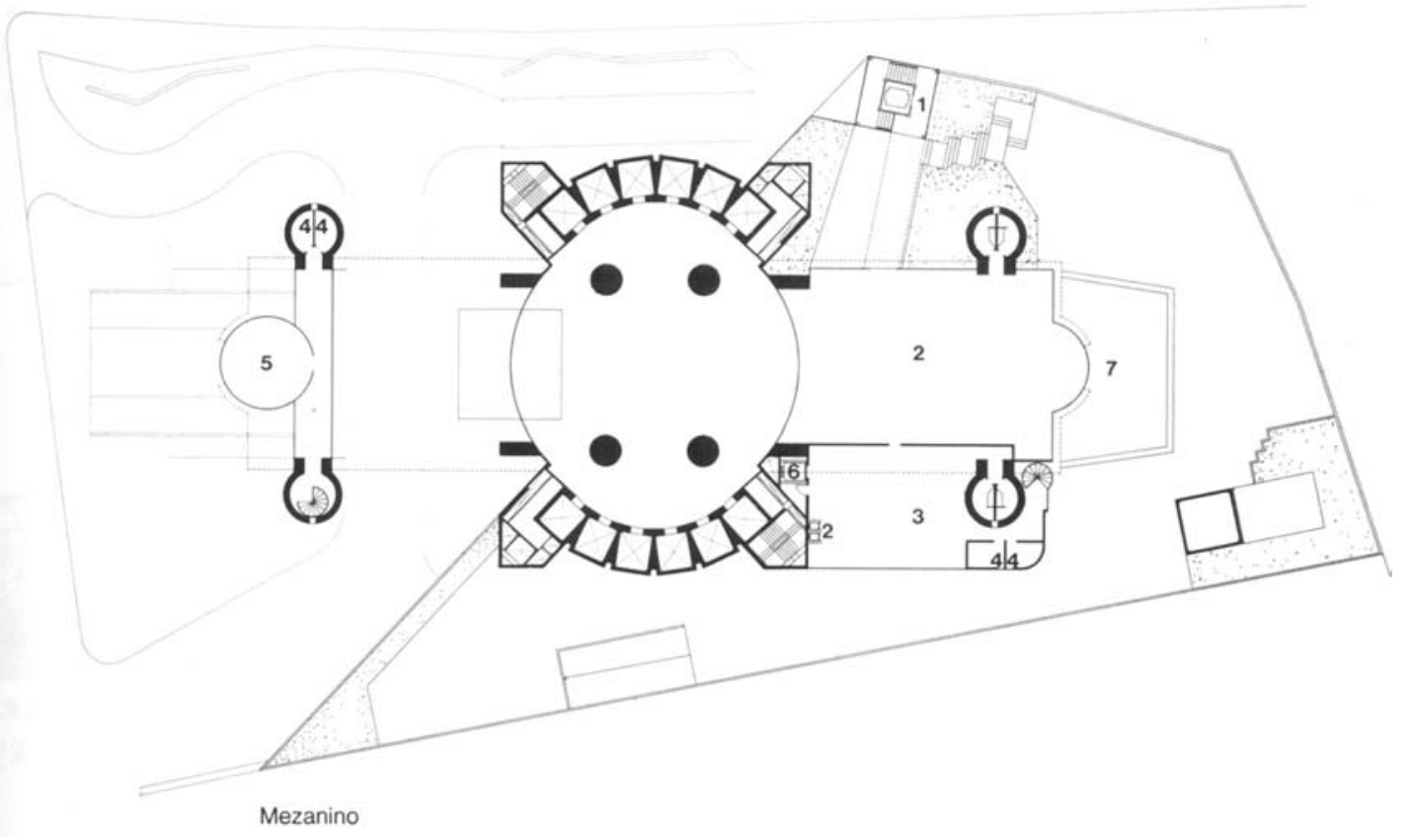

\subsection{Birmann 21}

Empreendimento pioneiro em uma região da cidade de São Paulo que, graças às facilidades de acesso, tem acentuada vocação para acolher grandes escritórios, o edifício Birmann 21 foi concebido pelo escritório norteamericano SOM - Skidmore, Owings \& Merril e desenvolvido e adaptado às normas e realidade brasileiras pelo escritório Kogan - Villar.

Uma torre com 26 pavimentos é naturalmente um elemento de destaque na paisagem urbana, mesmo numa cidade onde são comuns os edifícios altos, como São Paulo. Essa qualidade fica potencializada quando é pioneira numa região já bastante consolidada, mas cuja vocação comercial ainda não foi totalmente desenvolvida. Atuando há mais de uma década na região sul da cidade de São Paulo, a incorporadora Birmann decidiu apostar na vocação comercial e de serviços de toda a extensão da avenida das 
Nações Unidas, marginal ao Rio Pinheiros, que é uma das mais importantes artérias estruturadoras da circulação viária da cidade.

Ao definir-se a estratégia de criação desse novo empreendimento, decidiuse não apenas pela construção de mais um edifício de escritórios, mas pela criação de um marco urbano vertical, com desenho diferenciado e as mais inovadoras e completas tecnologias disponíveis.

A escolha dos arquitetos para definir esse novo marco buscou também inovar o mercado imobiliário, unindo experiência e ousadia. Com sua trajetória de mais de 35 anos no mercado brasileiro, caracterizados por um trabalho sério e voltado ao emprego e desenvolvimento de novas técnicas construtivas, a Kogan - Villar foi selecionada para trabalhar em equipe com o experiente e tecnicamente capacitado Skidmore, Owings \& Merrill, de Nova York, um dos maiores escritórios do mundo. Os resultados são linhas arquitetônicas arrojadas abrigando avançados recursos tecnológicos.

\section{Partido Arquitetônico}

A concepção inicial idealizada pelo SOM foi sendo aperfeiçoada, melhorada e alterada na medida das necessidades, com a ampla participação dos parceiros brasileiros. Trata-se, de fato, de uma co-autoria.

Fig. 85 Implantação Fonte: Revista Projeto Design no 193 jan/fev 96

Além disso, ambos os escritórios têm em comum sua visão da Arquitetura como um serviço a prestar a um cliente, onde o arquiteto nunca é unicriador absoluto

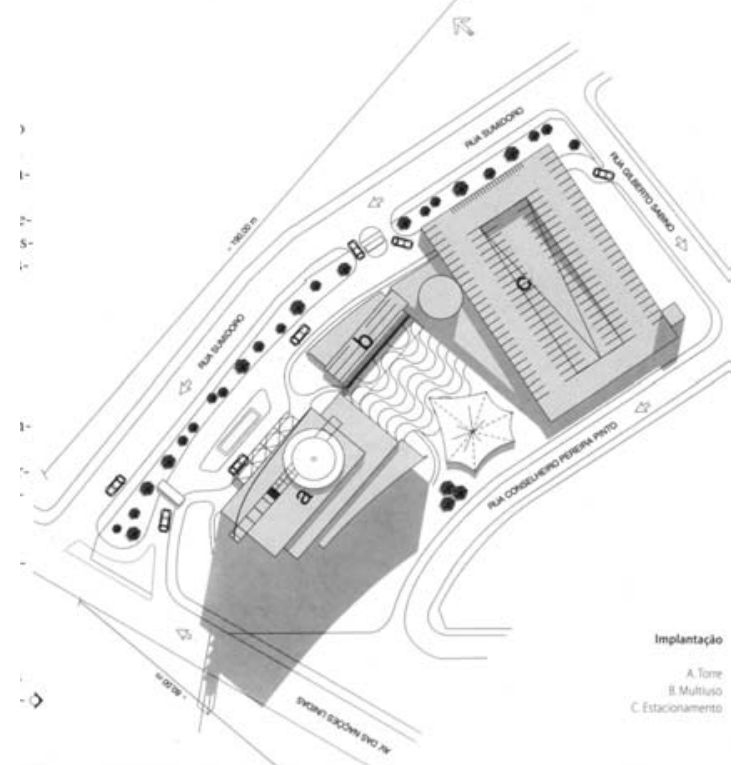
que impõe suas idéias, mas um profissional que interpreta os desejos do cliente, para realizar sua criação e definir os rumos estéticos da obra.

Na torre há um jogo com três tipos de grelhas, dispostas de maneira a sugerir o encaixe superposto. Duas são revestidas com granito e a outra formada por perfis de alumínio e cortina de vidro. A oeste, um volume envidraçado se destaca da fachada.

Birmann 21 é um conjünto composto por três edifícios: a torre, com 26 pavimentos de escritórios, gozando de amplos visuais para todos os pontos cardeais, mais próximas do alinhamento; o espaço de uso múltiplo, com estrutura metálica em balanço, abrigando um grande salão e salas de conferência; e o edifício-garagem com 6 pavimentos.

A concepção volumétrica da torr tipos de grelhas, dispostas de maneira a sugerir o enclaixe superposto: uma

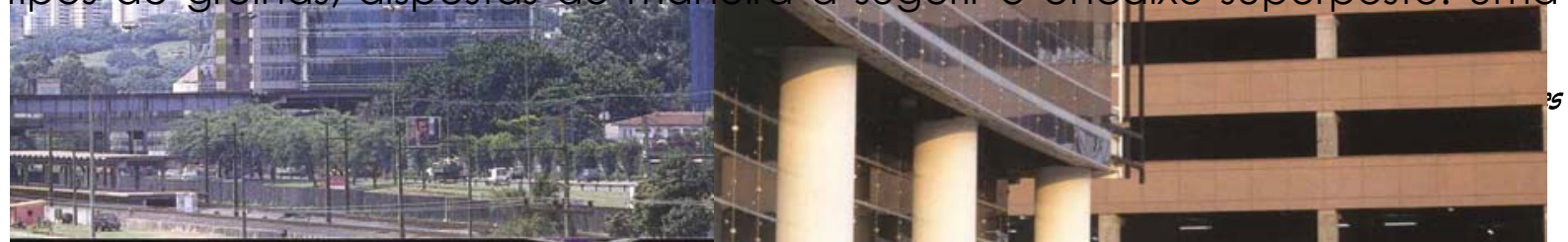


grelha estrutural com vãos mais fechados, revestidos com granito vermelho, voltado basicamente para as fachadas norte e oeste, mais ensoladas, mas que revela sua presença "fechando" o volume na altura do coroamento da torre; outra grelha de vãos mais abertos, revestidos com granito rosado, voltado basicamente para as fachadas leste e sul, menos ensoladas; e a grelha formada pelos perfis de alumínio, situada no lado externo e sustentam a cortina de vidro que se superpõe parcialmente sobre a fachada sul, destacada do solo pelos seus pilares cilíndricos.

Fig. 86 Detalhe da fachada

Fonte: Arquivo Pessoal

Fig. 87 Detalhe da fachada sul

$\mathrm{Na}$ fachada sul é possível observar o movimento sucessivo das grelhas graças à diferenciação das áreas das lajes. A fachada norte se mostra mais discreta, embora em ambas sejam utilizados vários recursos plásticos para assegurar certo grau de variação e movimento. No lado oeste criou-se pequeno volume vertical envidraçado que descortina uma vista espetacular da cidade, e serve de apoio a um mastro relembrando o perfil "arranha céu" característico das torres urbanas.

\section{Elevações diferenciadas em cada fachada}

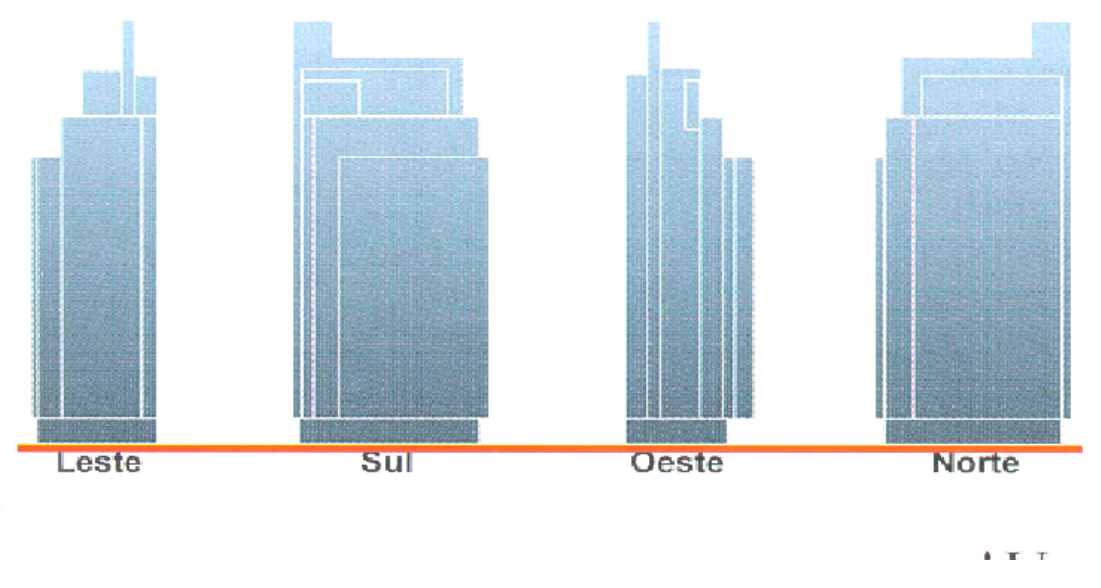

Fig. 88 Fachadas Diferenciadas

Fonte: Revista Projeto Design no 193 jan/fev 96

Os vidros empregados, do tipo reflexivo prata, têm grau de reflexão diferenciado de acordo com a fachada e as necessidades de controle da insolação.

Testes de túnel de ventos feitos nos laboratórios da Universidade Federal do

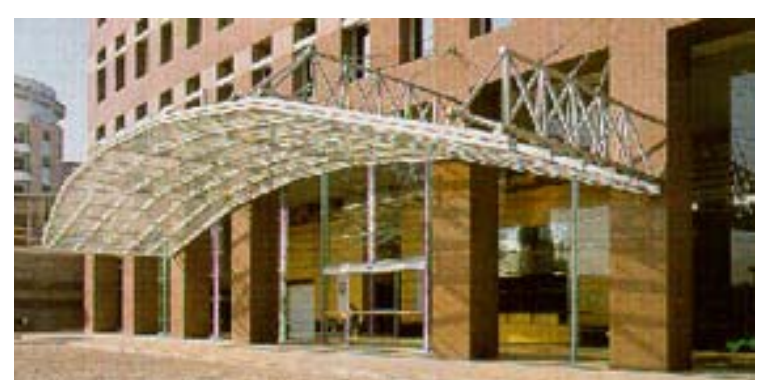
Rio Grande do Sul, forneceram os parâmetros para o dimensionamento da estrutura, perfis e vidros da fachada.

Uma marquise junto ao passeio externo protege veículos e pessoas 
que se dirigem ao pavimento térreo da torre, onde ficam a recepção e identificação dos visitantes, além de uma área reservada para usos especiais como agência bancária, showroom e etc.

Fig. 89 Marquise da entrada

Fonte: Revista Projeto Design no 193 jan/fev 96

O conjunto de escadas, sanitários e elevadores foi situado no core central, possibilitando a entrada de luz natural em todo o perímetro do edifício. Os elevadores foram situados em dois núcleos, que servem à primeira e à segunda metade vertical do edifício, otimizando sua utilização.

No topo da torre ficam o ático, com área de instalações e o heliponto.

Com áreas variadas de laje, o andar-tipo possui grandes vãos livres, já que a maior parte dos pilares foi localizada na periferia do andar. A sua concepção, com lajes de até $1460 \mathrm{~m}^{2}$ de área total e até $1250 \mathrm{~m}^{2}$ de área útil, permite um elevado índice de aproveitamento.

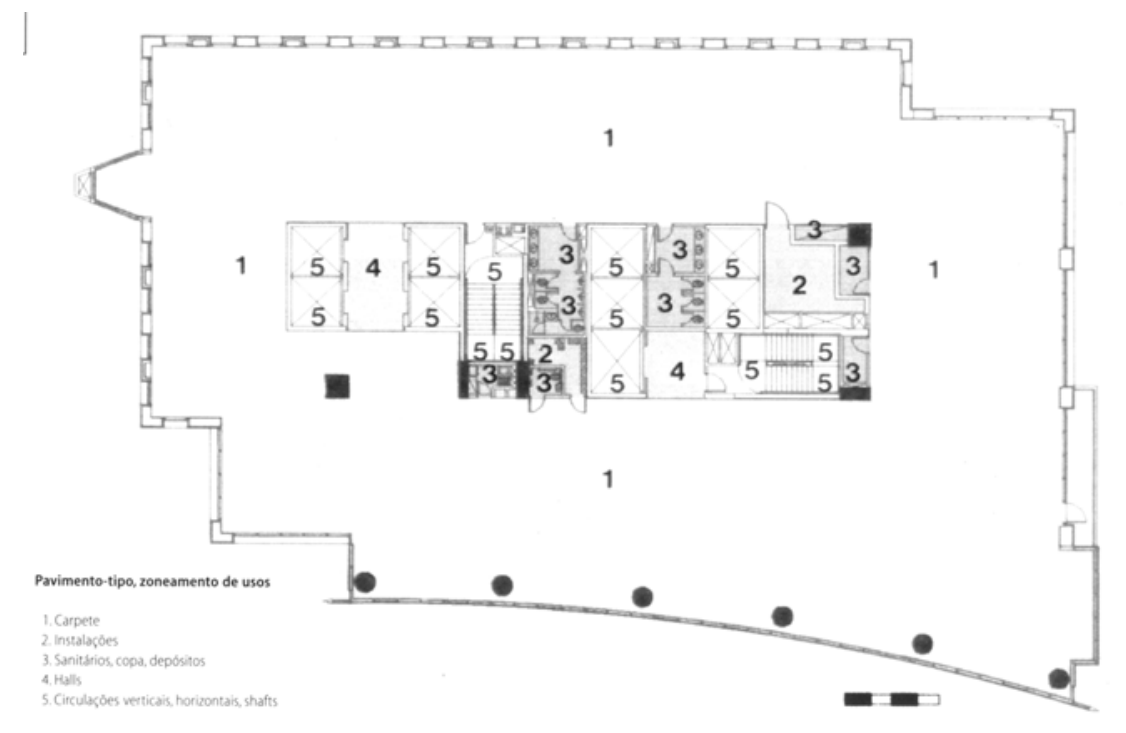

Fig. 90 Planta do pavimento tipo da torre Fonte: Revista Projeto Design no 193 jan/fev 96

\section{Tecnologias Utilizadas}

A altura de $4 \mathrm{~m}$ de piso a piso garante um pé-direito livre de $2,75 \mathrm{~m}$, contando com piso elevado em toda a área reservada para escritórios e forro modulado e removível, facilitando a paginação de luminárias de difusores e conferindo flexibilidade para os diferentes tipos de escritórios.

A utilização nas áreas internas da edificação de painéis de gesso tipo "drywall" para revestimento das alvenarias eliminou a aplicação de chapisco, emboço e massa, racionalizando os acabamentos. 
O desenvolvimento do sistema estrutural do Birmann 21 resultou de uma contínua interação entre engenheiros e arquitetos, o que permitiu a solução das questões de Arquitetura e assegurou uma necessária e freqüentemente difícil integração com os sistemas mecânico e elétrico.

A estrutura da torre foi totalmente moldada in loco. Para racionalizar o sistema construtivo, o núcleo da torre, que concentra circulação vertical, banheiros e áreas técnicas, foi moldado com concreto bombeado e estava sempre quatro pisos acima da laje nervurada que o contorna. Os vãos dessa laje variam de $10 \mathrm{~m}$ a 13,50 $\mathrm{m}$ e a altura de viga é limitada a $60 \mathrm{~cm}$, o que permitiu deixar espaço para dutos e tubulações.

As tubulações de sprinkler, no entanto, passam por pequenas perfurações previstas nas vigas. A laje nervurada foi moldada pelo sistema de fôrmas voadoras, que permitiu a conclusão de um pavimento por semana.

A integração entre estrutura e Arquitetura foi particularmente importante na definição do heliponto. A plataforma quadrada de $18 \mathrm{~m} \times 18 \mathrm{~m}$ tem um sistema de nervuras de $3 \mathrm{~m} \times 3 \mathrm{~m}$ e balanço de $-8,50 \mathrm{~m}$. A estrutura é suportada por uma grande caixa-d'água semicircular, integrada a uma densa viga circular, cuja função é uniformizar deflexões e momentos nas nervuras.

No térreo, a estrutura de aço do salão multiuso consiste em duas colunas principais com diâmetro de $600 \mathrm{~mm} \times 12,50 \mathrm{~mm}$ que suspendem a cobertura por meio de oito cabos de aço com diâmetros de $3 \mathrm{~mm}$. Quatro amarrações verticais foram colocadas na extremidade da cobertura, para evitar sua elevação pelo ação do vento. Uma estrutura mais baixa fornece rigidez lateral.

A concepção da torre e de suas áreas técnicas permite uma constante atualização dos equipamentos de telefonia, informática, transmissão de dados, automação e controle de sistemas prediais, gerenciamento energético, ar-condicionado, transporte vertical, iluminação e ainda segurança patrimonial e contra incêndio, impedindo a obsolescência precoce.

Complementando o programa da torre de escritórios e do edifício-garagem, criou-se entre ambos um edifício de uso múltiplo com $9 \mathrm{~m}$ de altura, concebido em estrutura metálica com apenas dois apoios e amplos balanços. Ele abriga um grande salão, de utilização flexível, além de salas de conferência. Está voltado para uma grande praça interna para a qual também se volta o térreo do edifício-garagem, que nesse setor tem uma área destinada a um, além de um espaço para fitness.

A extensão do terreno, que ocupa toda uma quadra, permitiu um amplo espaço para tratamento paisagístico, com emprego de vegetação e água. 


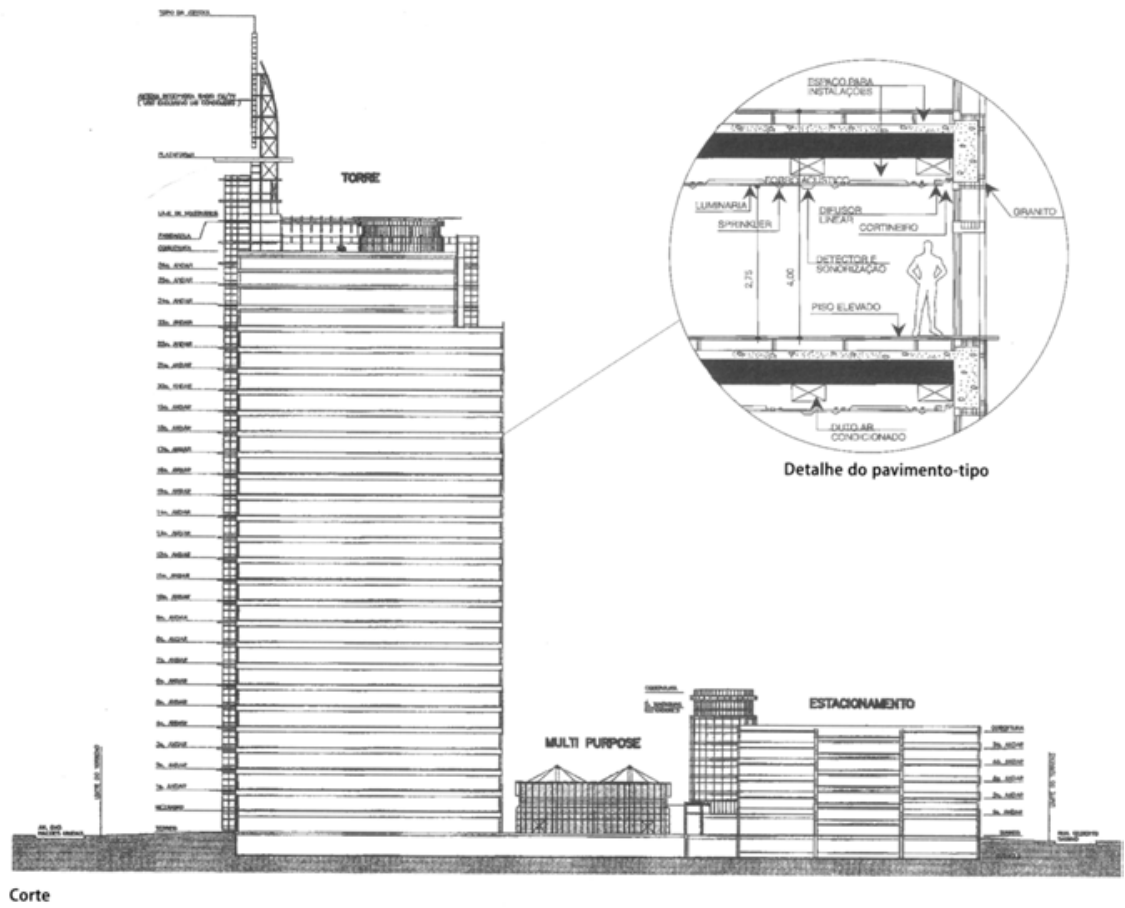

Fig. 91 Esquema da fachada ventilada, piso elevado e forro removível Fonte: Revista Projeto Design no 193 jan/fev 96

\subsection{Centro Empresarial Nações Unidas - CENU}

Conceber um conjunto de edifícios de escritórios e serviços nas dimensões do CENU implicaram redefinições a nível urbano e um partido arquitetônico muito particular. O "Nações Unidas", desenvolvido pelos arquitetos Marc Rubin e Alberto Botti, além de incorporar um "conceito avançado de escritório", se propõe a marcar o novo skyline do grande eixo da Marginal, em São Paulo.

Segundo seus autores, a proposta arquitetônica incorporou um conceito avançado de escritório, de uso e organização de espaços, seja ao nível de linguagem, seja em função de novos sistemas construtivos e processos tecnológicos, e fundamentalmente em termos de escala e programa, devendo configurar o "marco" diferenciador na emergente paisagem arquitetônica do grande eixo da Marginal, na Grande São Paulo.

A dimensão de conceito avançado se justifica, na própria performance das tecnologias de ponta e, conseqüentemente, de suas possibilidades e mutações, viabilizando novas soluções projetuais. Ou seja, em plena 'idade da informatização", o perfil de escritório moderno não é logicamente o mesmo de dez anos atrás. Trata-se, portanto - na opinião dos arquitetos de uma mudança de escala no sentido pleno, a nível do urbano ou na dimensão de espaços internos.

Os novos recursos tecnológicos, com suas redes de comunicação, "micros, vídeos, áudios e fax", impõem novos espaços, mais dinâmicos e flexíveis argumenta Marc Rubin. Redes para informática, correntes estabilizadas, fibras ópticas, além de ar-condicionado que hoje se reconhece como 
indispensável em São Paulo e ainda os problemas de segurança que, são objetos de uma atenção redobrada pelas dimensões do empreendimento, tudo isso, enfim, passou a ser essencial na definição do projeto. Inclusive o controle geral do que acontece nos edifícios supõe sistemas de supervisão centralizados, também previstos.

A dimensão das lajes assume, papel fundamental. A organização dos espaços internos garante maior flexibilidade e liberdade através de plantas livres. Os andares-tipo têm de 1.253 a $2.071 \mathrm{~m}^{2}$, e altura de $4 \mathrm{~m}$ ente pisos. Foi previsto um piso falso, tornando eficiente a distribuição dos condutores. Os forros contêm dutos para distribuição de ar-condicionado, além de redes de iluminação e sprinklers dentro da modulação geral do projeto. Com opções polivalentes, cada pavimento poderá ser ocupado integralmente ou em parcial, dependendo das necessidades do usuário.

Ao todo, são três torres que compõem o partido principal - a torre Oeste, a Norte e a Leste, destacando-se a Norte como a mais alta delas, com 36 pavimentos, $164 \mathrm{~m}$ de altura, e quatro subsolos. As outras deverão ter 23 pavimentos, $135 \mathrm{~m}$ de altura, e 0 mesmo número de subsolos. $O$ projeto inclui ainda um Centro de Convenções e um Conjunto Comercial de Apoio, além de três helipontos, totalizando cerca de 250 mil $\mathrm{m}^{2}$ de área construída coberta.

Fig. 92 Planta de localização das torres

Fonte: Revista Projeto Design no 193 jan/fev 96

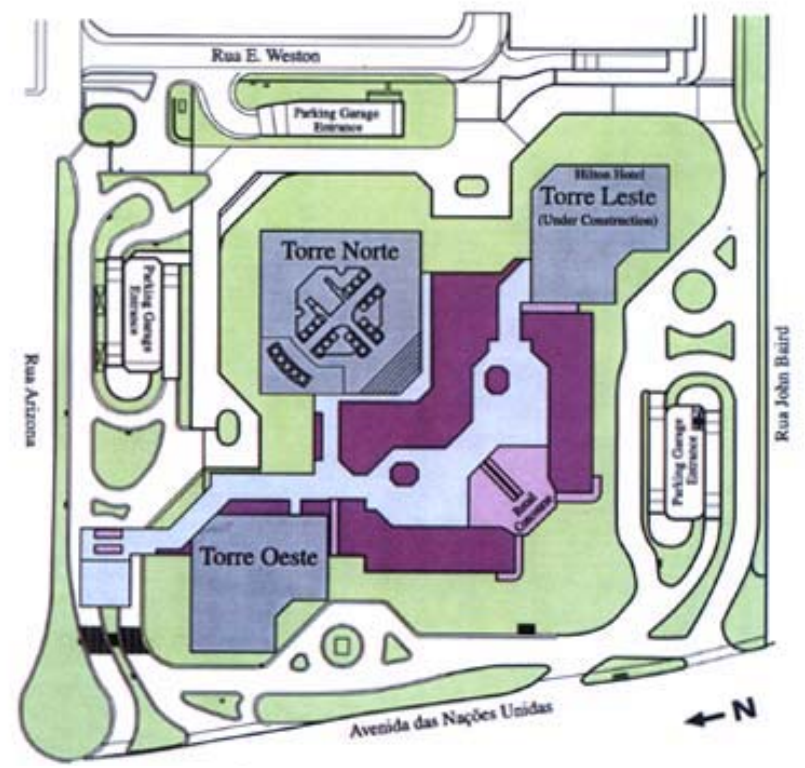

Apesar de interligadas, cada torre se revelará através de silhueta própria, com sua personalidade e seu toque de fantasia e sedução particular. 0 projeto em estrutura de concreto ficou sob a responsabilidade dos engenheiros Mário Franco e Júlio Kassoy.

\section{Partido Arquitetônico}

Segundo Rubin - "havia esse terreno com um ponto de interrogação, onde caberiam $\times \mathrm{m}^{2}$ de escritórios. Nós poderíamos dividí-lo e construir ali prédios diversificados. Poderíamos também, de acordo com o projeto original, construir quatro edifícios iguais colocados em cruz ou em outra forma, mas curiosamente desde os primeiros esboços feitos a mão livre, havíamos pensado em projetar três torres, sendo uma dominante e duas menores. Às vezes, o primeiro impulso conduz a uma solução, mas é necessário submetêla a uma série de checagens de alternativas, até se chegar à proposta 
final". Houve também, durante o desenvolvimento do projeto, um processo de evolução na percepção da verdadeira demanda de mercado.

O programa em síntese previa um centro empresarial que reunisse em seu bojo uma gama de edifícios, serviços e equipamentos dirigidos a seus usuários, como restaurantes, shoppings, agências bancárias, pontos de encontro, além de um centro de convenções, criando, com isso, um organismo que transcendesse a um simples conjunto de prédios de escritórios.

O item circulação mereceu atenção especial. O sistema de circulação vertical, com elevadores de última geração, prevê para cada prédio, além de maior eficiência na distribuição do fluxo de usuários, elevadores executivos e de serviço maiores que os demais. Naturalmente, também foi previsto sistema de baldeação para isolar o tráfego dos subsolos e dos estacionamentos. Ao todo são 52 elevadores.

Cada torre terá acesso exclusivo, elevadores, além de escadas rolantes que farão a conexão entre o subsolo e o térreo, cujas garagens possuem capacidade para mais de 3.500 vagas.

Na torre maior (Norte) existe um andar mecânico numa altura intermediária e parte dos elevadores servirá apenas aos andares inferiores e, em conseqüência, os superiores ganharão o espaço correspondente aos poços dos elevadores eliminados, sistema comum nas torres norte-americanas, mas pouco usado nos edifícios paulistas, cuja escala normalmente não justifica esse recurso.

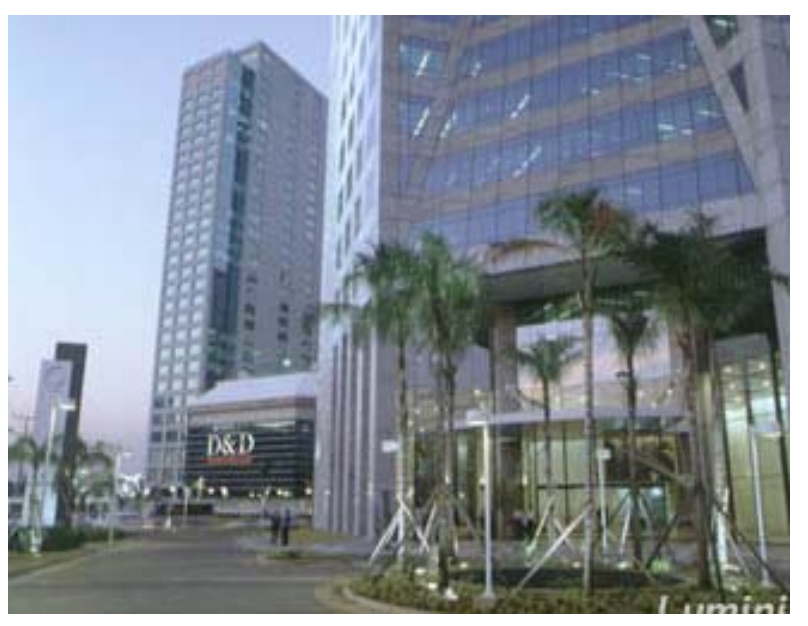

Com a colaboração de Burle Marx no desenho das áreas de circulação e jardins, o projeto - comenta Rubin "se cristaliza" como uma obra incomum. Pela sua dimensão e condições. o Nações unidas deverá surgir, enfim, como a nova marca na paisagem do grande eixo da Marginal, ao longo do qual começa a se desenhar a cidade mutante.

Fig. 93 Paisagismo da torre Oeste

Fonte: Arquivo Pessoal

O Cenu (Centro Empresarial Nações Unidas) é um dos projetos mais ousados do mercado imobiliário de São Paulo. O insere-se em uma lista de 39 edifícios com classificação AA (alta tecnologia), de acordo com um levantamento da Bolsa de imóveis de São Paulo. Para se ter uma idéia da atualização do empreendimento, 15 dos edifícios com a mesma classificação estão ainda em projeto ou construção. A área total construída do Cenu ultrapassa $300.000 \mathrm{~m}^{2}$. 


\section{Tecnologias Utilizadas}

\section{Torre Oeste}

A primeira torre a ser concluída foi a torre Oeste, em 1998, pela construtora HOCHTIEF do Brasil S/A. Sua área construída é de $76.655,75 \mathrm{~m} 2 \mathrm{com} 138 \mathrm{~m}$ de altura. Ela foi concebida para ser um edifício de escritórios tendo seu andar tipo com uma área de $1.110,00 \mathrm{~m} 2$. Podemos destacar como característica técnica desta torre a concepção arquitetônica da planta do andar tipo, onde há um deslocamento do core (elevadores e equipamentos), do centro de gravidade do andar, para o centro ao fundo permitindo assim um espaço ideal para instalações em landscape.

Setores de serviços, copas, sanitários foram simetricamente deslocados para as laterais do edifício, assim como as escadas de segurança, estas em especial formando um desenho na fachada.

Foram previstos shafts verticais, forros removíveis e pisos elevados, garantindo assim uma total flexibilidade para as instalações necessárias. O sistema estrutural foi feito em grelhas de vigas protendidas de $3.75 \mathrm{~m} \times 3.75 \mathrm{~m}$ com caixões perdidos nas lajes produzidas por formas metálicas.

A fachada é formada por uma grelha em granito polido cinza feita por uma paginação em placas de $2.60 \mathrm{~m} \times 1.40 \mathrm{~m}$ colocadas com grampos metálicas sobre o pré-moldado. Destaca-se também outro novo sistema tecnológico que foi o uso do gesso acartonado, usado como vedação para acabamento interno na periferia das fachadas.

Fig. 94 Torre Oeste Fonte: Arquivo Pessoal

O térreo foi projetado inicialmente para ser um espaço comercial, tendo sido restringido o seu uso somente para recepção e circulação, onde se situam os balcões de recepção que controlam as entradas e saídas dos elevadores.

Da Torre Oeste para a Torre Norte, o empreendimento passou por algumas atualizações em função das novas necessidades do mercado de escritórios com a vinda de empresas estrangeiras ao País. De acordo com o projeto original dos arquitetos Alberto Botti e Marc Rubin, as torres, embora diferissem nas dimensões, teriam conformações estruturais semelhantes, como o posicionamento da área de serviços, elevadores e shafts

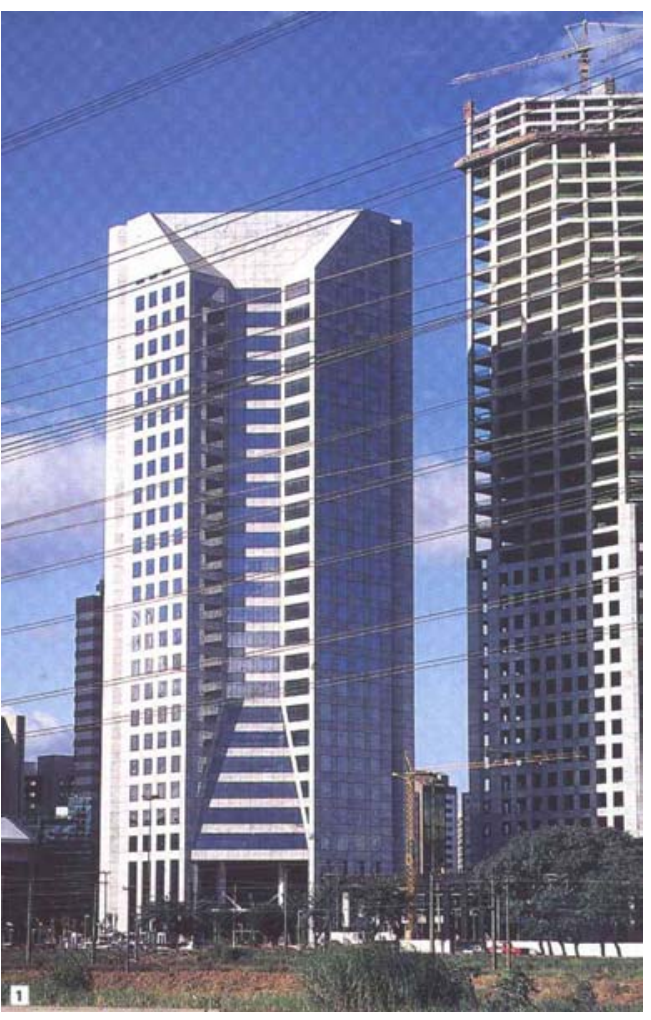
deslocado do centro. 


\section{Torre Norte}

A reformulação do projeto da Torre Norte trouxe o core do edifício para o centro, como forma de valorizar a área de carpete dos pavimentos. Com a mudança, a região do entorno do core ganhou lajes planas e os vãos entre os pilares saltaram de $3,75 \mathrm{~m}$ para $7,5 \mathrm{~m}$. No core central, porém, foram mantidas as lajes e vigas convencionais.

As escavações do terreno atingiram $20 \mathrm{~m}$ de profundidade e o radier octogonal, com $4 \mathrm{~m}$ de altura, consumiu $2.624 \mathrm{~m}^{3}$ de concreto. A sua

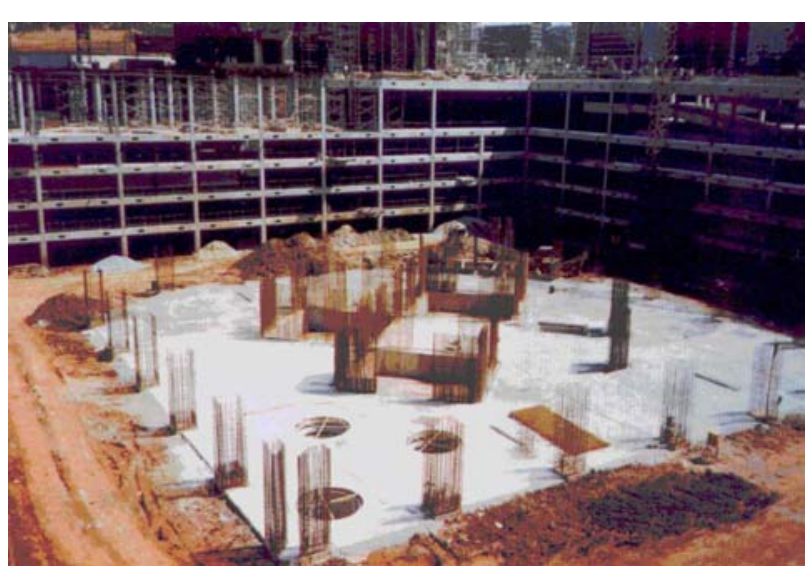
concretagem durou 72 horas ininterruptas, e através de ensaios para controle de temperatura da concretagem do bloco central de fundações foi possível atingir as resistências definidas em projeto.

Fig. 95 Fundação da torre Norte Fonte: Revista Téchne mai/jun 1999 n॰ 40

A obra utilizou concretos de alto desempenho entre $35 \mathrm{Mpa}$ (lajes e vigas) e $50 \mathrm{Mpa}$ (pilares) valores bastante superiores aos utilizados na torres oeste (25 MPa). Grande parte das cargas da torre norte, cerca de 62.000T, está concentrada no centro do edifício, que coincide com um grande bloco de fundação, enquanto as cargas sobre os pilares periféricos da torre não ultrapassam 4.000T. Porém a

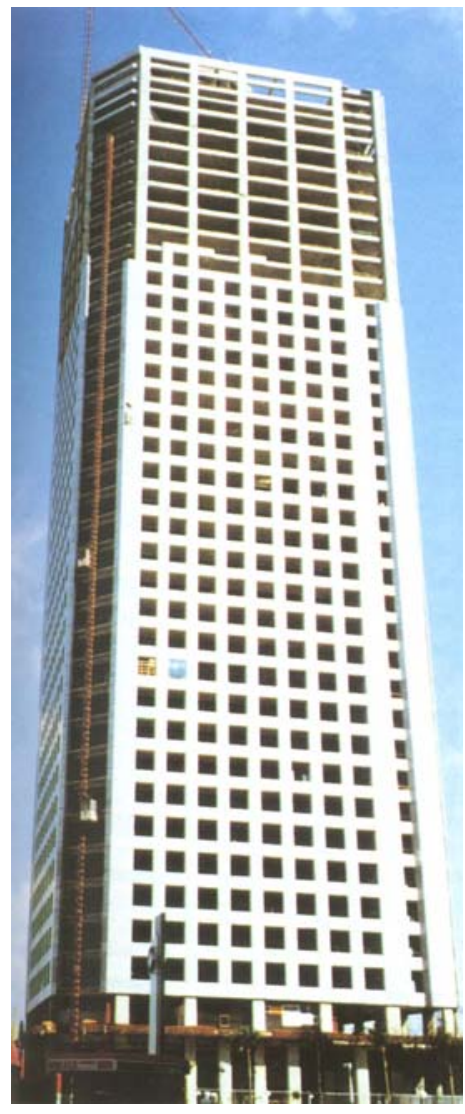
adoção de lajes planas com $21 \mathrm{~cm}$ de espessura demandou uma análise apurada do comportamento estrutural. Para reduzir a possibilidade de deformações, o engaste das lajes utiliza armaduras negativas junto aos pilares.

Além disso, um rigoroso controle tecnológico de lançamento de concreto das fundações foi feito pela consultora Maria Noronha e, no restante da estrutura, foi feito pelo professor Paulo Helene, da Poli-USP.

Fôrmas do tipo mesa-voadora foram fundamentais à Concretagem de uma laje por semana.

Outra característica arquitetônica que demandou cuidado foi o próprio formato do edifício. A estrutura segue regular até $024^{\circ}$ pavimento, como um paralelepípedo. Daí para cima o edifício é chanfrado.

Nas fachadas, painéis pré-moldados de concreto, cuja fôrma era o próprio granito de revestimento, fecham a estrutura. Internamente, placas de gesso 
acartonado fazem o acabamento.

Fig. 96 Fachada Pré-moldada da torre Norte

Fonte:Revista Téchne mai/jun 1999 n० 40

O fechamento das fachadas é completado por esquadrias com vidros duplos, totalizando $27 \mathrm{~mm}$ de espessura. O sistema garante uma eficiência acústica mínima de $35 \mathrm{db}$. A isolação acústica é melhorada com a existência de ar entre os vidros, vedados com silicone. A produção dos caixilhos foi feita no próprio subsolo do edifício, com equipamentos enviados da Itália.

Ensaios no Túnel de Vento permitiram redução de cerca de 1,5 T de armadura por pavimento além de verificar os índices de conforto para os usuários nas áreas de circulação comum entre as torres, de acordo com os critérios de uso.

O sistema de ar condicionado da Torre Norte conta com uma central de água gelada. O sistema permite estabelecer temperaturas entre $20^{\circ} \mathrm{C}$ e $24^{\circ} \mathrm{C}$, conforme as necessidades dos diferentes ambientes ou zonas.

O nível de ruído do sistema de ar-condicionado nas salas é de NC40. Este índice é praticamente igual ao de um teatro.

Para abastecimento de energia em emergências, existem geradores de energia de comando digital que podem abastecer com folga todos os circuitos de segurança, como pressurização de escadas, iluminação do hall, alguns elevadores, ventiladores de exaustão de emergência, parte da iluminação dos escritórios e equipamentos de detecção e combate a incêndio.

A distribuição vertical emprega, em vez de cabos, barramentos blindados isolados térmica e eletricamente. A distribuição horizontal é feita por cabos convencionais a partir dos "plugins" de derivação fixados às barras na região dos shafts.

O sistema de proteção e combate ao fogo é dotado de detectores de fumaça ópticos não voláteis e de sprinklers. A automação predial inclui sistemas de acesso, circuitos fechados de TV, hidráulica, elétrica e controle de incêndio.

Outros pontos que merecem destaque são:

Saguão - O saguão, com pé-direito de 7,2 m de altura, assume um tom de

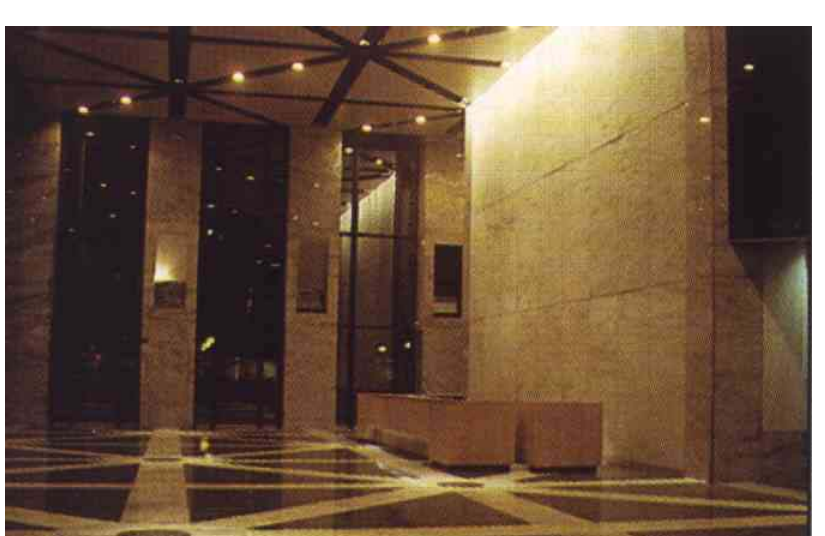
solenidade. O mesmo tipo de granito da fachada se faz presente no piso, com uma diferença: a paginação utiliza placas inteiriças de $1,20 \mathrm{~m}$. O forro, acústico, tem acabamento cenotécnico

de utilizado tecido no 
planejamento de teatros. Além da função estética, apresenta características técnicas de absorção acústica, já que os materiais utilizados são extremamente reverberativos.

Fig. 97 Saguão da torre Norte

Fonte: Arquivo Pessoal

Área de Circulação - A praça, onde acontece o cruzamento dos acessos às baterias dos elevadores, é valorizada por uma cúpula em forma octogonal formada por vidros craquelados, com luminárias importadas dos Estados Unidos. As paredes são revestidas com vidros arquitetônicos decorativos. $O$ balcão principal de recepção se encontra próximo às portas giratórias da entrada. O saguão também está equipado com sistema de catracas controlado por seguranças.

\section{Layout (andar-tipo e ambiente interno) -}

A flexibilização do layout constitui outro diferencial do projeto.

Fig. 98 Layout totalmente flexível

Fonte: Arquivo Pessoal

Seguindo o conceito de "estação de trabalho", cada pavimento-tipo

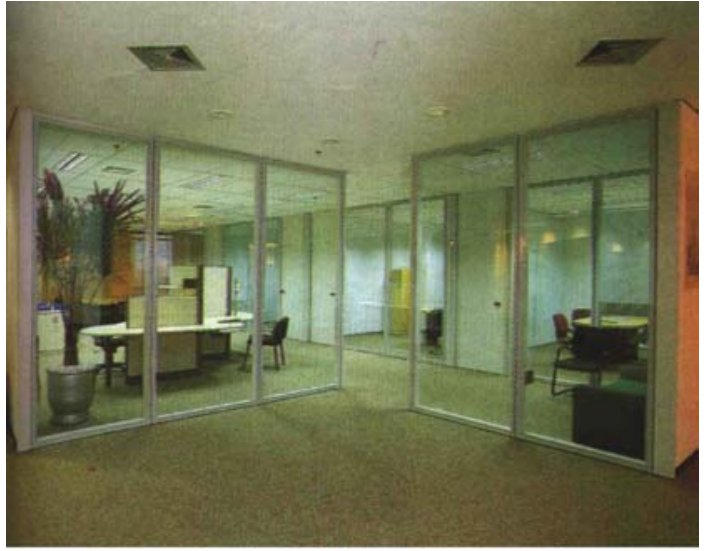
incorpora quatro salas de $800 \mathrm{~m}^{2}$ a $1.680 \mathrm{~m}^{2}$ de área útil total, com pé-direito padrão de $2,80 \mathrm{~m}$. A altura facilita a presença de forros suspensos, com luminárias integradas, difusores de ar e sprinklers. O forro, importado dos EUA, é acústico e antichama.

Mobiliário - O inquilino tem toda a liberdade quanto à definição e execução do design do imobiliário e do projeto de interiores. Mas qualquer interferência estrutural (obra) deve ser aprovada pelo condomínio para não fugir das guide-lines do projeto como um todo.

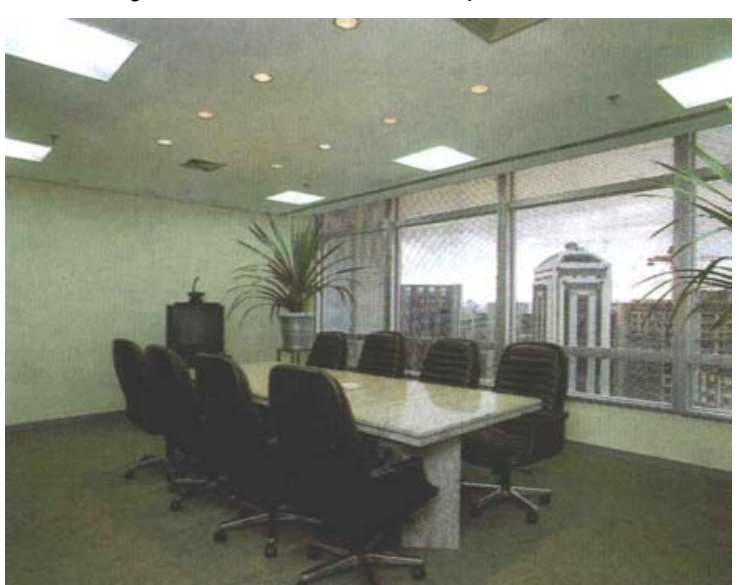

Fig. 99 Exemplo de Mobiliário Fonte: Arquivo Pessoal

Fachadas - A fachada externa foi revestida com materiais que permitissem fácil manutenção, custo reduzido e vida útil maior. A opção foi pelo granito Kashmir Bahia polido granulado branco acinzentado, que foi aplicado sobre painéis pré-fabricados ou placas de concreto. A pré-fabricação industrial garantiu a precisão na montagem feita em forma de "L"s sucessivos, seguindo o sentido de uma espiral. 
Projetados pela Stamp, os painéis utilizaram as próprias placas de granito como fôrma. Colocadas sobre elas, às armaduras já formam as alças de içamento dos painéis. Nessa etapa ficam também incorporadas ao concreto às ancoragens de aço inoxidável do granito. $O$ peso dos painéis varia de 2,5 T a $4 \mathrm{~T}$. Os elementos pré-moldados não se limitaram à fachada. As escadas de incêndio e serviços também são pré-moldadas, mas com um detalhe: diferentemente dos painéis, as escadas foram produzidas no Paraná.

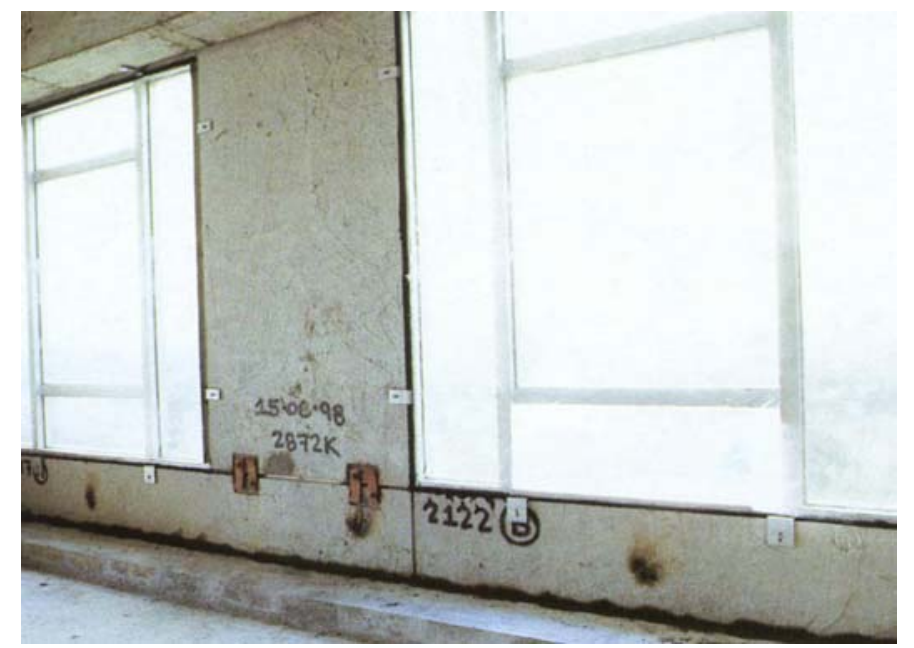

A vedação das juntas e dos vidros dos painéis recebeu dupla camada de silicone produzido pela Dow Corning do Brasil. A caixilharia de alumínio, e todos seus componentes foram desenvolvidos pela Shuco, empresa italiana, que trabalhou. Com um nível de tolerância em torno de $0,01 \mathrm{~mm}$ nos serviços de encaixe e vedação.

Fig. 100 Detalhe do encaixe da esquadria Fonte: Revista Téchne mai/jun 1999 n॰ 40

Vidros - Atendendo às necessidades térmicas e acústicas do projeto, foi utilizado o vidro insulado termoacústico (sanduíche composto de vidro laminado, câmara de ar e vidro monolítico), na cor verde-azulada de baixa reflexão que retém cerca de $77 \%$ do calor externo e cuja laminação foi feita no Canadá. A Falco Tradin Comercial participou da montagem da vedação das fachadas. As dimensões das janelas tipo são de $2,48 \mathrm{~m}$ de altura e $2,28 \mathrm{~m}$ de largura. $O$ processo de montagem, quatro vezes mais rápido que 0 convencional de alvenaria, atingiu a velocidade de dois pavimentos por semana.

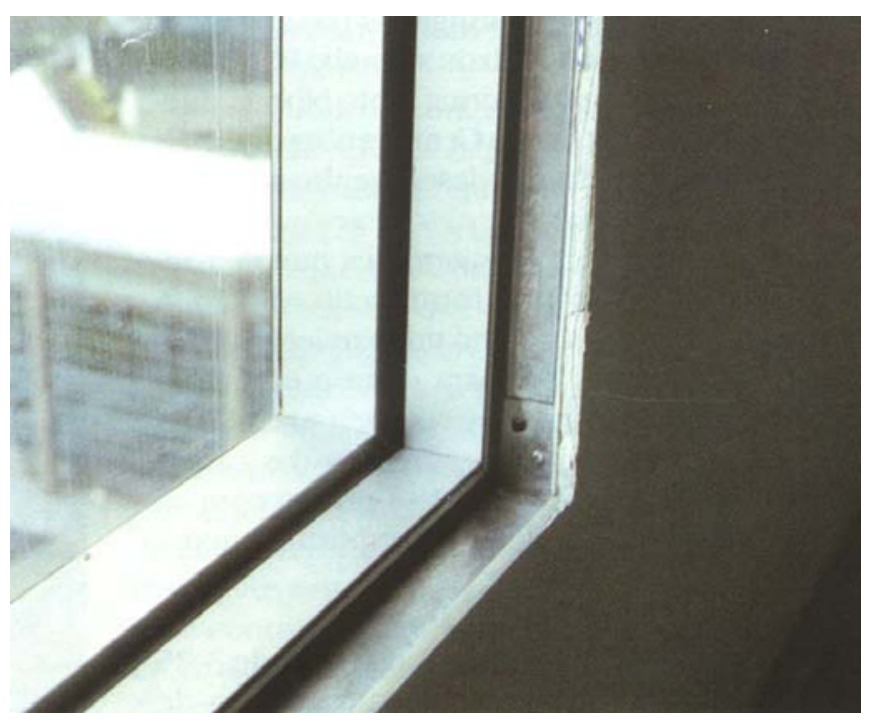

Fig. 101 Detalhe do vidro duplo Fonte: Revista Téchne mai/jun 1999 n॰ 40 
Gesso Acartonado - A divisão interna, por outro lado, alternou o uso de placas de gesso acartonado para a periferia da fachada e alvenaria, para área de elevadores. $\bigcirc$ fechamento interno das paredes e fachadas utilizou o

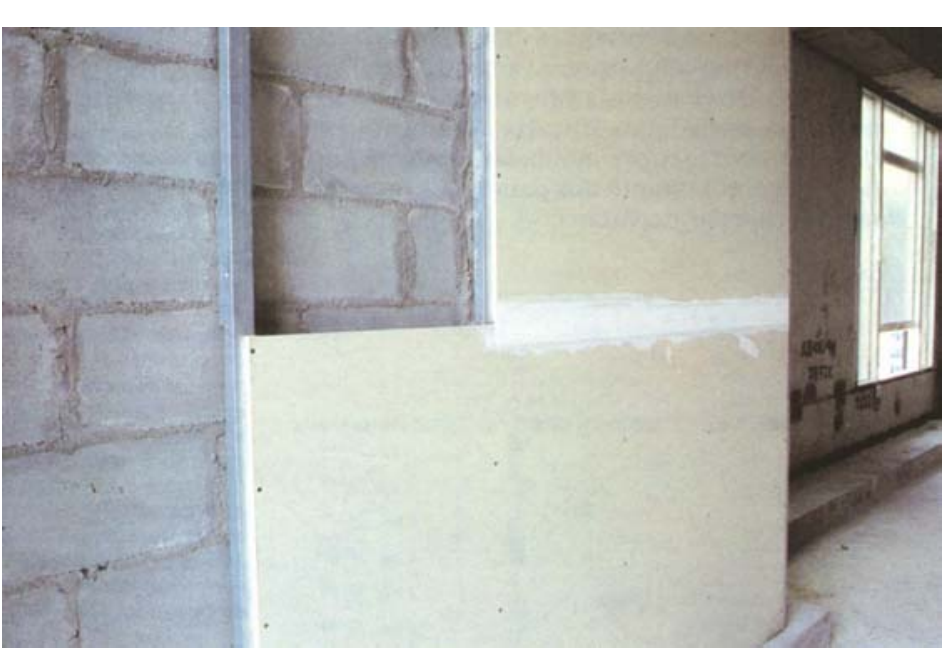

acartonado sistema Drywall, ou seja, estruturas de perfis metálicos sobre os quais foram parafusadas as chapas de gesso acartonado. O sistema garantiu, durante a obra, maior agilidade e limpeza, uma vez que as instalações elétricas e hidráulicas eram feitas antes do revestimento, evitando os tradicionais "rasgos" na alvenaria.

Fig. 102 Detalhe do gesso

Fonte: Revista Téchne mai/jun 1999 no 40

O sistema utilizado é o Placostil F 530, da Placo, um perfil mais esbelto. As paredes de periferia de fachada não utilizam lã mineral nas vedações. "Essa vedação é apenas de acabamento, não tem nenhuma função corta-fogo", diz Fábio Miceli, da Dry Tech.

A empresa executou cerca de 13,5 mil $\mathrm{m}^{2}$ de vedação de fachada, além de outros 5,2 mil m² de fechamento de banheiros. "A Método nos deu algumas condições de estanqueidade na obra e pudemos assim executar as paredes dos banheiros ainda com as fachadas abertas", diz Miceli.

Os banheiros utilizam placas verdes (resistentes à umidade) com uma ou duas chapas estruturadas em perfis de $90 \mathrm{~mm}$ e miolo de lã de vidro de 50 $\mathrm{mm}$ de espessura $\left(16 \mathrm{~kg} / \mathrm{m}^{3}\right)$. O fechamento das fachadas é completado por esquadrias fabricadas pela italiana Shuco, com vidros duplos que totalizam $27 \mathrm{~mm}$ de espessura.

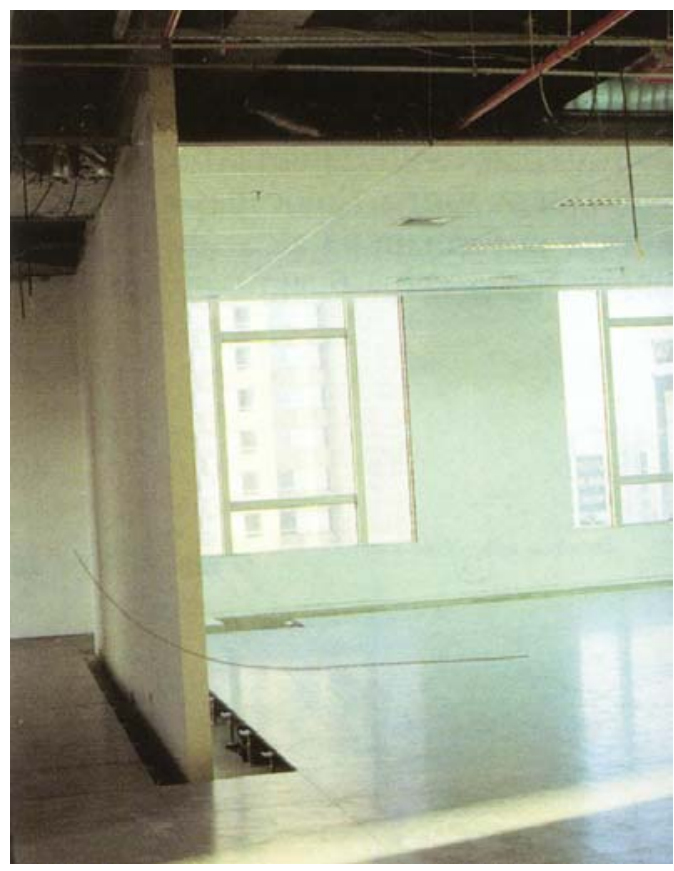

Piso Elevado - oferece, entre a cota da laje do concreto e o piso acabado, uma área vazia de $15 \mathrm{~cm}$ para a instalação de infra-estrutura de dados, informática e telefonia, além de cabeamento elétrico. O sistema facilita futuras adaptações ou mudanças de layout e proporciona fácil acesso às instalações. Prumadas hidráulicas nos quatro ângulos do edifício permitem a instalação de sanitários individuais especiais, caso sejam requeridos pelo inquilino.

Fig. 103 Detalhe do piso elevado

Fonte: Revista Téchne mai/jun 1999 no 40 
O núcleo central de cada pavimento abriga um lavabo feminino e outro masculino, sanitários coletivos e um lavabo exclusivo para portadores de deficiência física.

A Torre Norte pertence ao Funcef (Fundo de Pensão dos Funcionários da Caixa Econômica Federal), que detém também $50 \%$ das áreas comuns do Cenu. A entrada da Funcef foi decisiva para a viabilização do empreendimento, mobilizando cerca de $\mathrm{R} \$ 160$ milhões. O conjunto irá contar com 3,7 mil vagas de garagem em seus cinco subsolos.

A administração predial das torres e áreas comuns do Cenu está sendo feita pela Tishman Speyer-Método. A administração se estende também a área de varejo em construção entre as torres, que terá acesso ao Shopping D\&D e World Trade Center. Além de parceira na administração predial com a construtora Método, a Tishman Speyer responde pelo desenvolvimento e gerenciamento da obra.

\section{Torre Leste}

A terceira torre, a torre Leste, da mesma altura da torre Oeste com 138m, inicialmente foi projetada para ser uma torre de escritórios, agora está sendo desenvolvida para comportar o Hotel Hilton, com 506 apartamentos.

Com a finalização da torre Norte e a conclusão dos cinco subsolos, algumas adaptações estão sendo feitas, tanto nos subsolos como no térreo a fim de permitir a inclusão dos espaços necessários para as salas de convenções.

No andar tipo, uma estrutura totalmente diferente foi idealizada, não havendo mais a necessidade de espaços livres de pilares, foi feita uma adaptação às fundações, sendo também reduzida à distância piso a piso

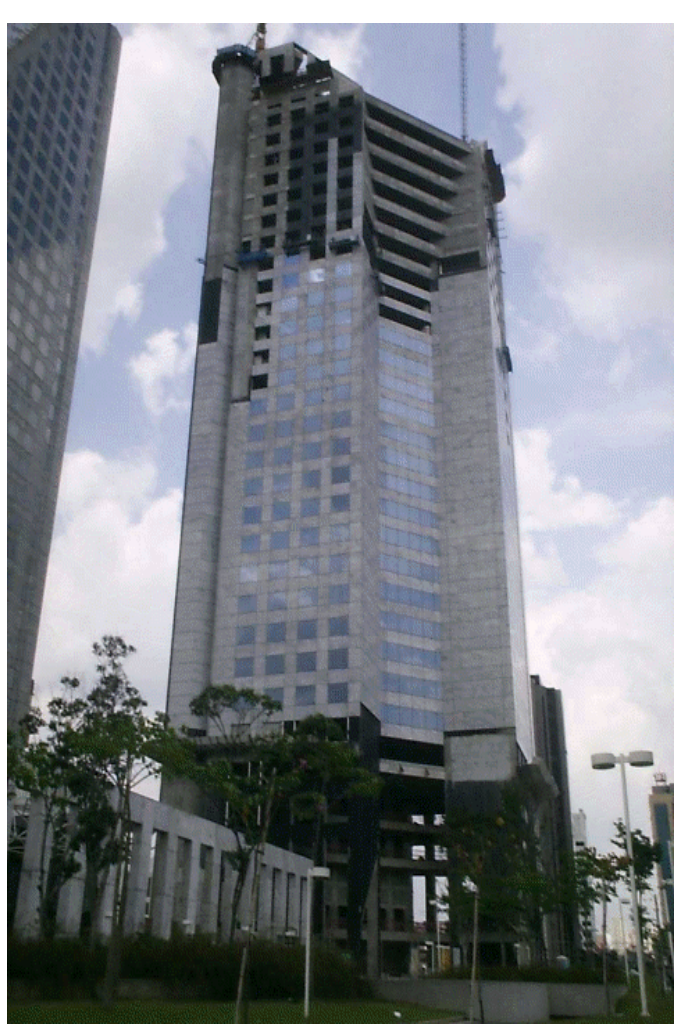
das lajes.

A paginação dos caixilhos foi alterada em resultado da modulação nova, mas esta não afetará a unidade do conjunto, pois a geometria original será repetida.

O Hilton terá 26 andares, onde estarão os apartamentos que compreendem os do tipo padrão, suítes especiais, suítes lounge e suíte presidencial, que ficará no $24^{\circ}$ pavimento. Além disso, haverá três mezaninos, onde ficarão o restaurante e o business center (salas de reunião), e um health club, com vista panorâmica da cidade nos $25^{\circ}$ e $26^{\circ}$ andares. No térreo haverá um ball room (centro de convenções). 
Fig. 104 Torre Leste

Fonte: Arquivo Pessoal

Os banheiros são um dos principais diferenciais da obra, pois são préfabricados e entregues já com todos os equipamentos e acabamentos previstos nos projetos de Arquitetura e instalações, inclusive o quadro elétrico.

\begin{abstract}
As paredes são de gesso acartonado e merece destaque o sistema de hidráulica, que utiliza uma das tecnologias mais modernas no mercado: o Sistema PEX, que consiste em tubos de polietileno reticulado que distribuem a água diretamente do manifold (quadro) aos pontos de consumo. Este conjunto oferece inúmeras vantagens quando comparado ao sistema convencional, que além de permitir maior rapidez na execução e menor mão de obra, a manutenção dos equipamentos e os rearranjos arquitetônicos também são mais fáceis.
\end{abstract}

Fig. 105 Detalhe de interligação dos banheiros pré-fabricados com as prumadas

Fonte: Arquivo Pessoal

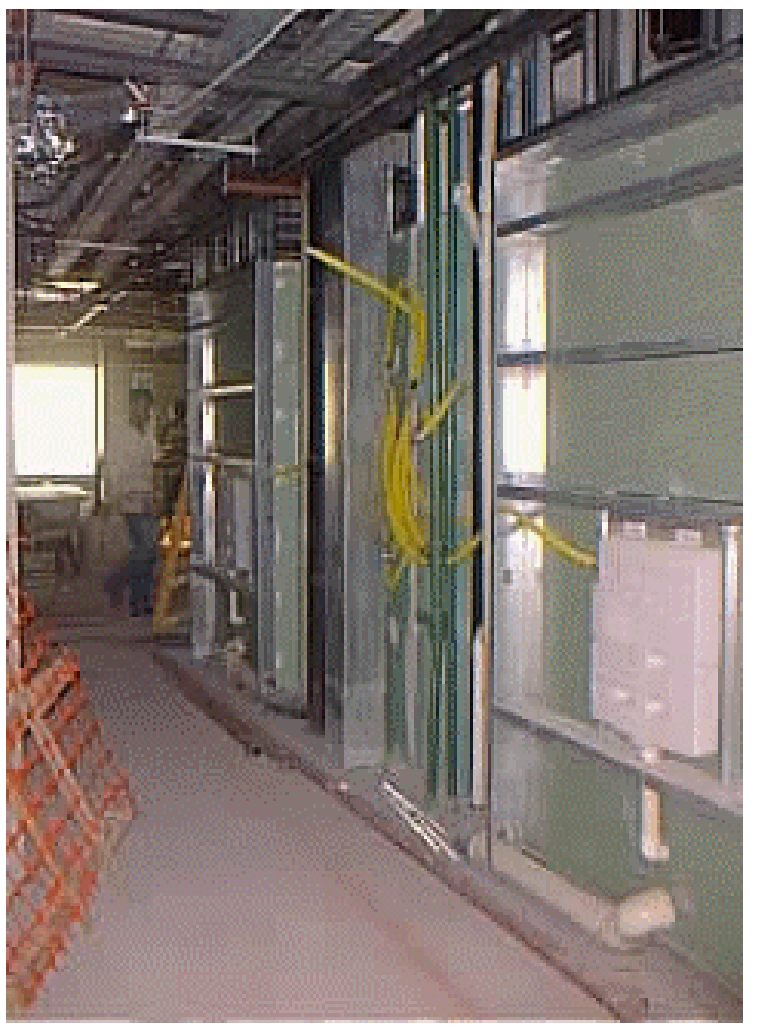

Os quartos receberam tratamento acústico com lã de vidro, material que atenuará o nível de ruídos em até $50 \mathrm{Db}$. Além disso, houve a preocupação de projetar cada caixa de passagem das instalações distanciadas em dez centímetros para garantir o nível de atenuação.

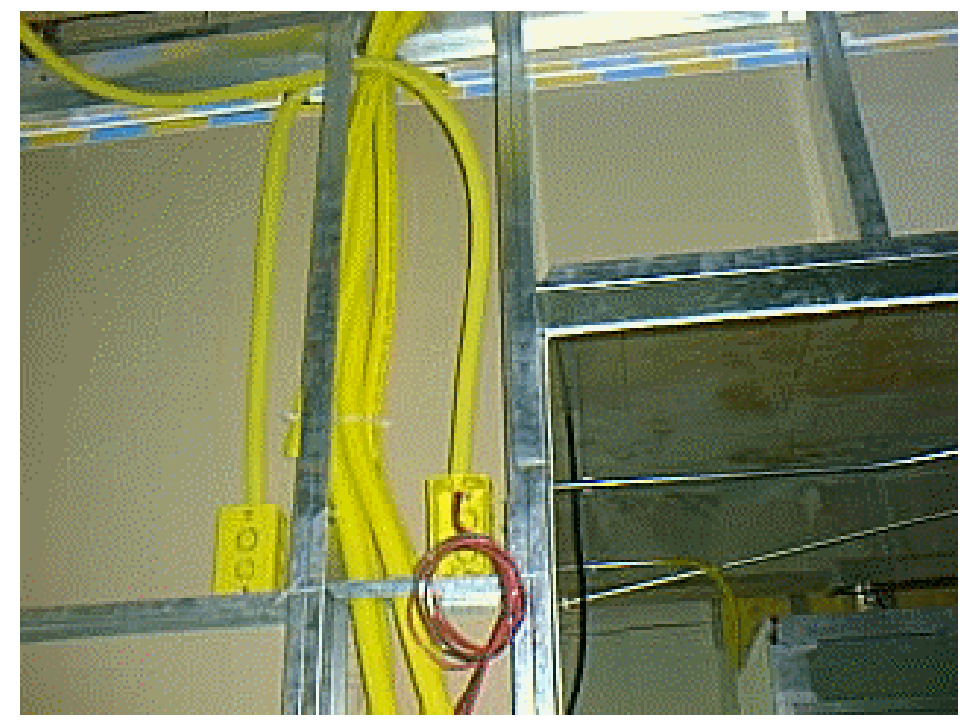

Fig. 106 Instalações de um apartamento padrão antes do fechamento do Dry wall Fonte: Arquivo Pessoal 
Quanto ao sistema de Prevenção e Combate a Incêndio, foram previstos sprinklers convencionais e do tipo side wall (fixados na parede), além de detectores de fumaça.

Como o Hilton visa hospedar exclusivamente executivos, todos os quartos possuem um escritório com tomadas para notebooks, como puderam ser observados em dois apartamentos protótipos. Uma curiosidade: há a previsão para instalação futura de um sistema eletrônico que registra a abertura do frigobar.

No primeiro e segundo subsolos serão instalados a cozinha central, refeitório dos funcionários, vestiários e lavanderia. No terceiro, além do Júnior Ball Room, ficarão as equipes de manutenção do hotel (engenharia e supervisão predial).

As centrais de água gelada e de água quente e mais a subestação de energia estão localizadas no quarto subsolo e, devida à altura destes equipamentos, foi necessário especificar um pé-direito duplo.

No último subsolo, estão a caixa d'água, com 500 mil litros e os reservatórios de esgoto, águas pluviais e águas servidas, equipados com bombas submersíveis.

O Hilton terá uma reserva de 1 milhão de litros de água, o que eqüivale a um consumo diário de 1.500 litros de água por apartamento.

Prevista para ser concluída em junho de 2002, totalizando uma área de 61.402.15 $\mathrm{m}^{2}$, esta torre então virá a se somar com as outras duas (Oeste e Norte), para concluir este mega empreendimento.

\section{Centro Comercial}

Interligando as três torres foi erguido um centro comercial, prevendo uma população máxima flutuante de 9.000 pessoas, oferecendo equipamentos, serviços e comércio.

A fim de preservar os espaços públicos de circulação e as áreas verdes do térreo, esta área foi edificada num nível inferior, $6 \mathrm{~m}$ abaixo do térreo, onde o acesso é feito por escadas rolantes e elevadores de baldeação dos edifícios de escritórios e do hotel.

Para evitar um efeito de confinamento, a cobertura da área central foi feita com iluminação zenital estando no nível do primeiro andar das torres, com uma altura de $17 \mathrm{~m}$, permitindo a vista do exterior através de grandes panos de vidro laterais.

O projeto deste centro foi concluído em 1999, com uma área de 4.222,45m², interligado em prolongamento ao mini-shopping e a praça de alimentação do World Trade Center, completando um grande complexo de 
equipamentos a disposição de um público que abrange um perímetro maior, servindo a todo bairro.

\section{Estacionamento}

Finalizando este complexo temos a área de estacionamento com um total de $132.700 .00 \mathrm{~m}^{2}$, cinco subsolos com 3.600 vagas. Possui dois sistemas de rampas duplas em tesoura, (uma em cada canto do terreno), uma rampa com sentido reversível e uma rampa especial de serviço para abastecimento do centro comercial e acesso de caminhões para mudanças, totalizando seis rampas.

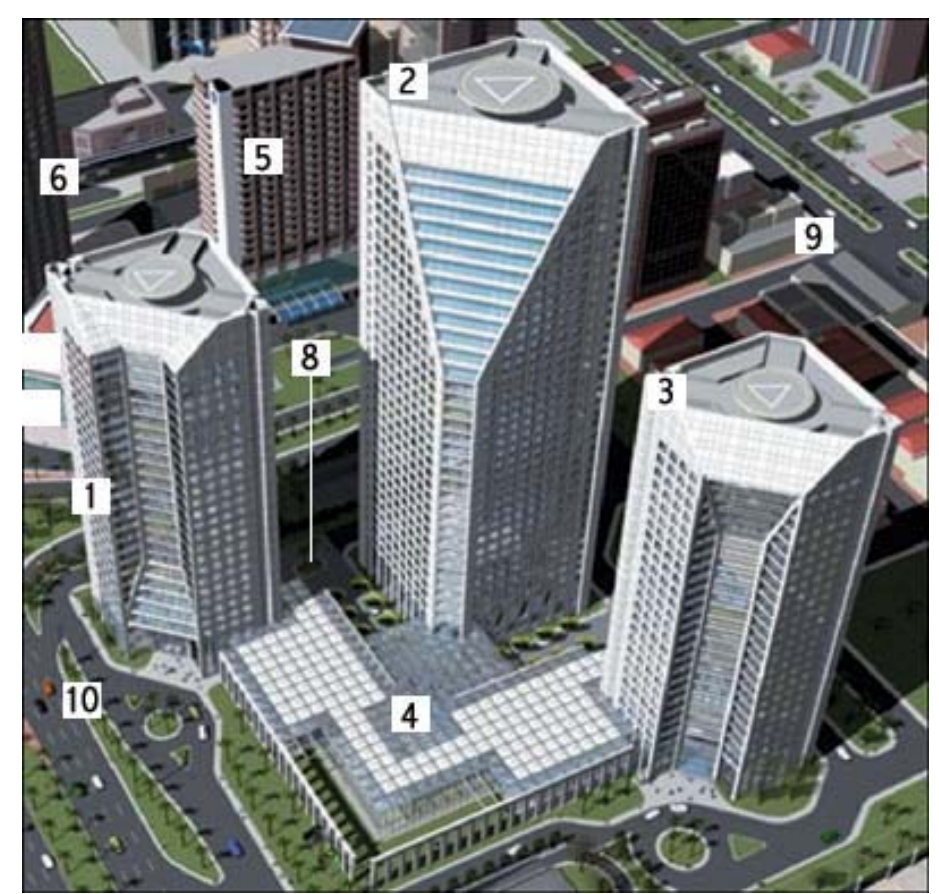

Fig. 107 Maquete Eletrônica do Complexo CENU e prédios vizinhos

Fonte: bolsa de imoveis

Legenda:

1 - Torre Oeste - Prédio de Escritórios e Centro de Convenções

2 - Torre Norte - Prédio de Escritórios

3 - Torre Leste - Hotel Hilton - em construção

4 - Shopping Nações Unidas

5 - Hotel Meliá

6 - WTC - Prédio de Escritórios

7 - Shopping D\&D

8 - Corredor subterrâneo que faz a ligação dos complexos WTC e CENU

9 - Acesso pela rua Arizona

10 - Acesso pela Marginal Pinheiros 
5 Organização dos Sistemas e Serviços e a Integração entre eles 
As capacidades dos sistemas presentes num edifício avaliam-se pelas funções que executam. Essas funções, que podem ser bastante diversificadas, possuem, características que as permitem agrupar em conjuntos (tais como a sua natureza, o seu âmbito, ou os seus objetivos).

É nesta perspectiva que se introduz a noção de serviço, a qual corresponde a um conjunto de funções que, justificam o seu agrupamento numa entidade individualizada, por várias razões, como a sua natureza, a sua íntima inter-relação e/ou dependência, a sua partilha ou intervenção sobre informação comum ou a sua associação a um mesmo tipo de equipamento físico.

Deve-se salientar que as funções desempenhadas por um serviço não precisam estar forçosamente associadas a dispositivos físicos (envolvendo interações com sensores e atuadores). Um serviço pode ser constituído apenas por funções de natureza software.

Deste modo, uma base de dados ou um determinado programa específico podem também ser considerados serviços. Ou seja, a noção de serviço é bastante genérica, podendo ser aplicada aos mais diversos domínios e não se restringindo apenas à área da automação e gestão de edifícios.

Como definição de um sistema de supervisão e controle predial, ou simplesmente automação predial, pode-se dizer que ele é uma ferramenta eficiente e efetiva para a boa operação e controle das instalações de infraestrutura e dos usos finais de energia de um edifício.(Marte, 1995)

O que caracteriza um edifício automatizado é o fato dele ser dotado de um sistema de controle central que pretende otimizar certas funções inerentes à sua operação e administração. É algo como um edifício com vida própria, com cérebro, sentidos, músculos e nervos. As características fundamentais que devemos encontrar num sistema inteligente são:

- Capacidade para integrar todos os sistemas;

- Atuar em condições variadas, ligadas entre si;

- Ter memória suficiente;

- Ter noção temporal;

- Fácil interligação com o utilizador;

- Ser facilmente reprogramável;

- Dispor de capacidade de autocorreção;

Em todo o caso, a principal virtude destes controles, está na nova concepção da gestão de sistemas, deixando o modelo eletromecânico convencional e adotando um modelo puramente informático e computadorizado. 
Infelizmente, muitos dos ditos Edifícios Inteligentes não o são na realidade ou não realizam com fluidez as funções para que foram projetados. Eles falham nos objetivos fundamentais tendo em vista as necessidades dos seus utilizadores. Muitos são super dimensionados, oferecendo sistemas que na maioria dos casos não são utilizados.

Como exemplo podemos citar um sistema de comunicação integral em fibra óptica, talvez nunca seja necessária essa tecnologia. Por outro lado, aquilo que hoje poderá parecer inteligente, será obsoleto no Futuro. Não podemos esquecer que a tecnologia é simplesmente uma ferramenta de trabalho moderna, e como todas as ferramentas, deve ser utilizada de acordo a sua utilidade final.

Os Edifícios Inteligentes ajudam os seus proprietários. Se administrados corretamente ajudam os seus utilizadores e apresentam benefícios nas áreas de custo, conforto, conveniência, segurança, concorrência, flexibilidade de utilização e melhoramento. Não há inteligência no limiar do 'ótimo' e do 'fracasso'. O Edifício Inteligente ideal é aquele que interliga as soluções de acordo com as necessidades dos usuários".

O simples emprego de computadores para o controle dos processos em uma edificação não garantem por si só alcançar parte dos objetivos a que se propõe um edifício automatizado.(Marte, 1995).

É necessário fazer-se uma administração de complexidades, que envolve desde o conhecimento do processo até a influência da automação no desempenho global, para que se faça a melhor escolha entre as inúmeras técnicas digitais de controle e otimização disponíveis.

Devido aos vários problemas atuais em relação à geração e distribuição de energia elétrica torna-se necessário racionalizar e gerenciar o seu uso final. Como uma das principais ferramentas para racionalização e gerenciamento do uso da energia elétrica em uma edificação, temos os sistemas de supervisão e controle predial.

Abaixo apresentamos um organograma que articula a gestão aos sistemas, serviços e estrutura e demonstra o papel vital da integração, conseqüentemente, da importância das questões de gerenciamento.

Edifício Inteligente

\begin{tabular}{|c|c|c|c|c|}
\hline GESTÃO & SIS & & SERVIÇOS & ESTRUTURAS \\
\hline $\begin{array}{l}\text { FACILIDADE DE } \\
\text { GESTÃO }\end{array}$ & $\begin{array}{l}\text { SISTEMA DE } \\
\text { HVAC }\end{array}$ & $\begin{array}{l}\text { SISTEMA DE } \\
\text { INCÊNDIO }\end{array}$ & $\begin{array}{c}\text { VÍDEO } \\
\text { CONFERÊNCIA }\end{array}$ & $\begin{array}{l}\text { ARQ. ESTRUTURAL } \\
\text { FLEXÍVEL }\end{array}$ \\
\hline $\begin{array}{l}\text { GESTÃO DE } \\
\text { SEGURANÇA }\end{array}$ & $\begin{array}{l}\text { SISTEMA DE } \\
\text { ILUMINAÇĀO }\end{array}$ & $\begin{array}{l}\text { SISTEMA DE } \\
\text { ELEVADORES }\end{array}$ & $\begin{array}{l}\text { SISTEMA } \\
\text { CABD }\end{array}$ & $\begin{array}{c}\text { ESTRUTURA DE ACESSO } \\
\text { EXTERIOR }\end{array}$ \\
\hline $\begin{array}{l}\text { GESTÃO DE } \\
\text { CABLAGEM }\end{array}$ & $\begin{array}{l}\text { SISTEMA DE } \\
\text { ENERGIA }\end{array}$ & $\begin{array}{l}\text { SISTEMA DE } \\
\text { SEGURANÇA }\end{array}$ & PABX & $\begin{array}{c}\text { SISTEMA INTELIGENTE } \\
\text { POR PISO }\end{array}$ \\
\hline $\begin{array}{l}\text { GESTÃO DE } \\
\text { ENERGIA }\end{array}$ & $\begin{array}{c}\text { SISTEMA DE } \\
\text { TELECOMUNICAÇÕES }\end{array}$ & $\begin{array}{l}\text { SISTEMA DE } \\
\text { DDC }\end{array}$ & $\begin{array}{l}\text { COMUNICAÇĀO POR } \\
\text { SATÉLITE }\end{array}$ & $\begin{array}{c}\text { ESTRUTURAÇÕES POR } \\
\text { DIVISÕES }\end{array}$ \\
\hline
\end{tabular}


Na figura abaixo, caracterizamos e localizamos os principais sistemas e serviços oferecidos nos Edifícios Inteligentes:

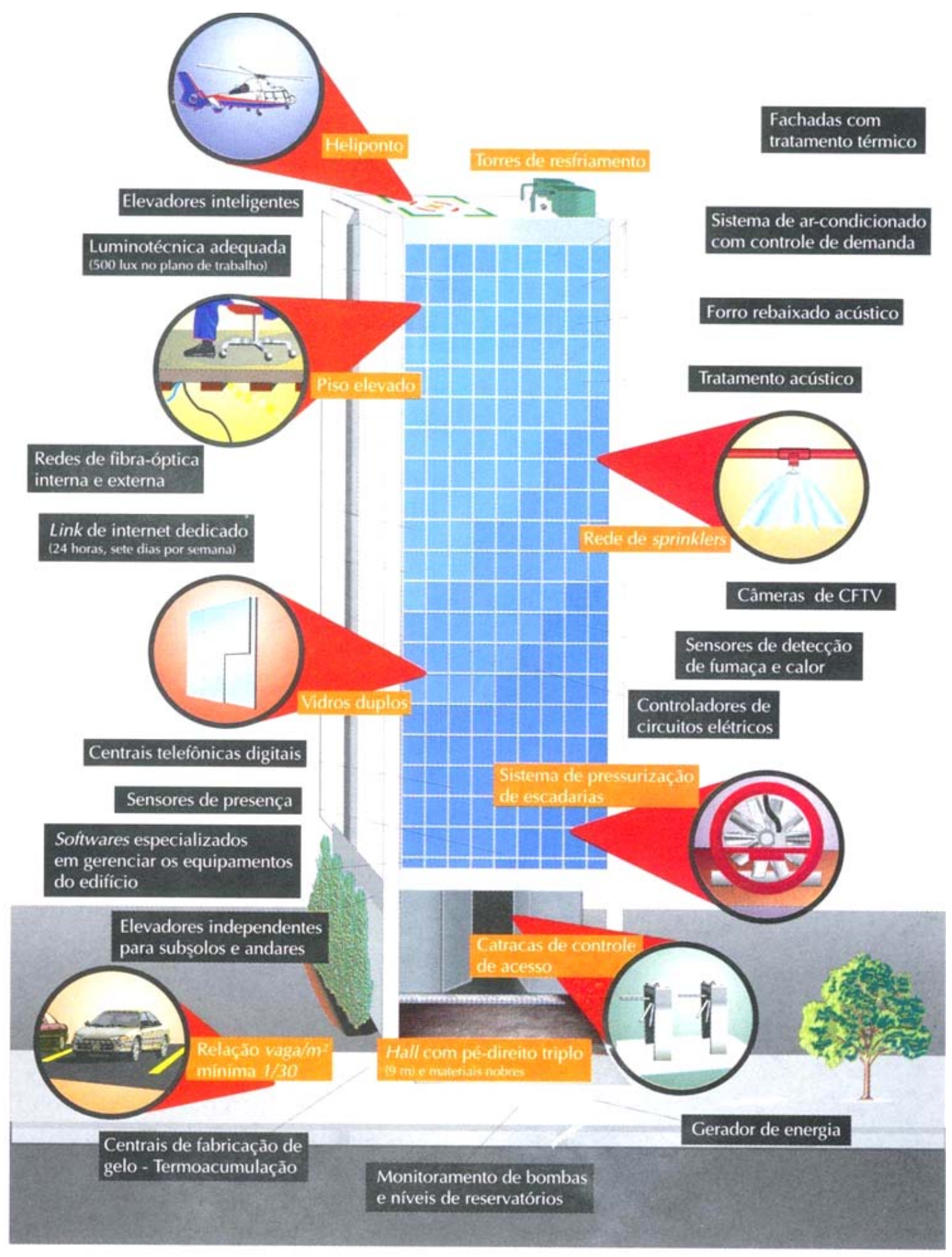

Fig. 108 Sistemas e Serviços oferecidos nos Edifícios Inteligentes Fonte: Revista Téchne out 2001 no 55 


\subsection{Sistemas de Automação Predial \\ 5.1.1 Elétrico / lluminação}

Segundo Marte (1995), devem ser levadas em conta as preocupações com:

$\checkmark$ Controle de Demanda

$\checkmark$ Controle do Fator de Potência

$\checkmark$ Automatismo de partida de geradores e transferência de cargas

$\checkmark$ Controle de lluminação

$\checkmark$ Otimização do Consumo - por exemplo, Programação Horária.

As preocupações acima listadas levaram os sistemas de automação predial ou sistemas específicos de controle de grandezas elétricas a se interligarem para supervisionar e controlar:

$\checkmark$ Transformadores;

$\checkmark$ Disjuntores de alta e baixa - tensão;

$\checkmark$ Quadros de alimentação de equipamentos;

$\checkmark$ Centrais de medição de grandezas elétricas;

$\checkmark$ Controladores de demanda:

- Registradores Digitais de Tarifação Diferenciada (RDTD),

- Registradores Digitais de Média Tensão (RDMT),

a Registradores Digitais Eletrônicos (REP), que possuem canal serial de comunicação;

$\checkmark$ Controladores do fator de potência,

$\checkmark$ No-break's: alguns tendo microprocessadores em seu controle e comunicação serial;

$\checkmark$ Grupos geradores: geradores de energia autônomos, geralmente a óleo ou gás, que fornecem energia quando há queda no fornecimento.

Para permitir diminuir o consumo de energia junto à concessionária nos horários de ponta são utilizados nos edifícios com alta tecnologia diversos mecanismos, sendo os comumente encontrados: tanques de gelo ou piscinas de água gelada no condicionamento ambiental (termo acumulação).

Os circuitos dos quadros de iluminação podem ser comandados em blocos para ligar/desligar através de Programação Horária - instantes pré-definidos para ligamento/desligamento - ou Controle de Demanda.

Em especial sobre a lluminação, responsável em média por 30 a $50 \%$ do consumo de energia nas edificações, existe a possibilidade de associar-se 
controles individualizados com sensores de presença. Outra melhor possibilidade é o melhor aproveitamento da iluminação natural através da associação com sensores de luminosidade.

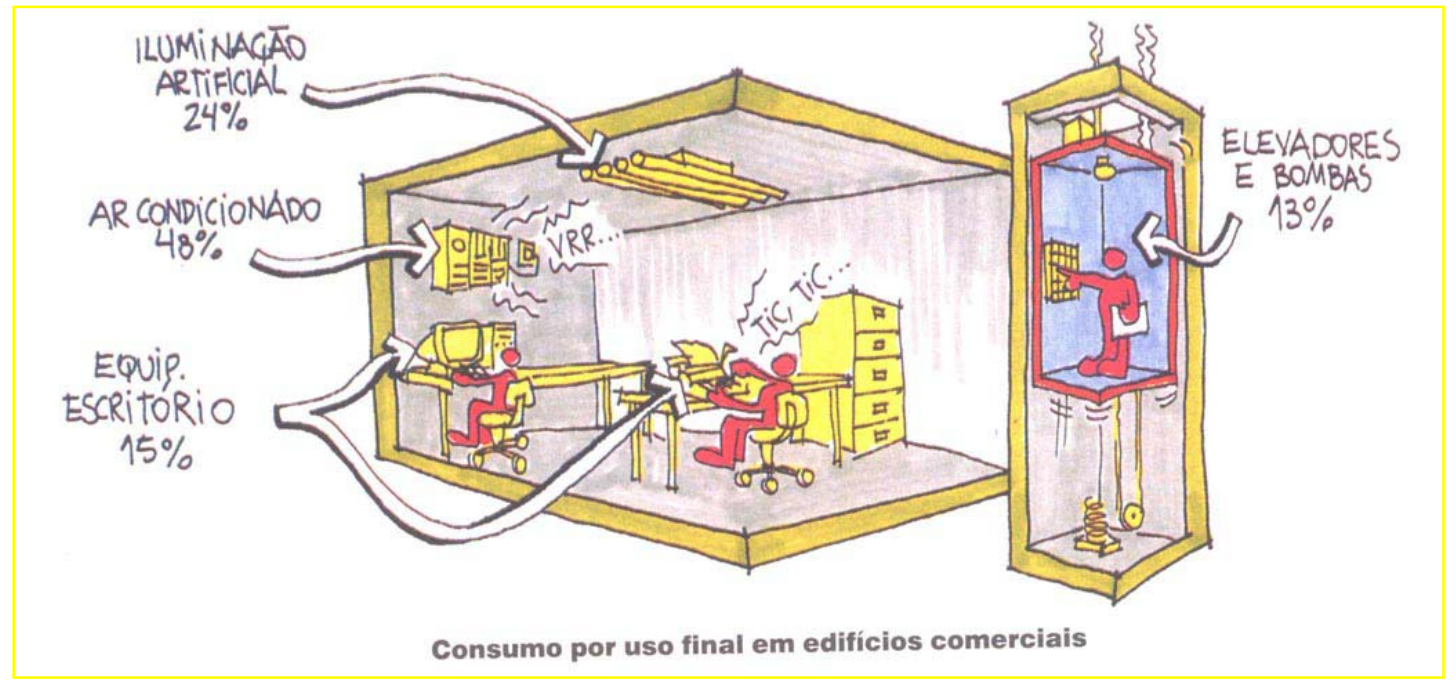

Fig. 109 Consumo por uso final em Edifícios Comerciais

Fonte: Eficiência Energética na Arquitetura Lamberts, 1997

\section{Caso CENU - SP}

Para abastecimento de energia, o Cenu possui uma estação de média tensão de $34,5 \mathrm{KV}$, com dois circuitos redundantes (chaveamento eletrônico em caso de falha). A potência instalada apenas da Torre Norte é de 7,5 MVA. A subestação emprega disjuntores a gás SF6 e transformadores a seco, que fazem a conversão de $34,5 \mathrm{KV}$ para 380V. Para abastecimento de energia em emergências, o edifício conta com geradores de energia Caterpillar de comando digital com capacidade total de 1000 KVA.

O sistema de emergência pode abastecer com folga todos os circuitos de segurança, como pressurização de escadas iluminação do hall, alguns elevadores, ventiladores de exaustão de emergência, parte da iluminação dos escritórios e equipamentos de detecção e combate a incêndio.

A distribuição vertical emprega, em vez de cabos, barramentos blindados. São ao todo três barramentos com capacidade máxima de 4 mil ampères isolados térmica e eletricamente. A distribuição horizontal é feita por cabos convencionais a partir dos "plugins" de derivação fixados às barras na região dos shafts. Toda a automação predial, como sistemas de acesso, circuitos de tevê, hidráulica, elétrica e controle de incêndio, é feita pela Landis \& Gyr.

Fig. 110 Gerador da Compaq - CENU

Fonte: Arquivo Pessoal

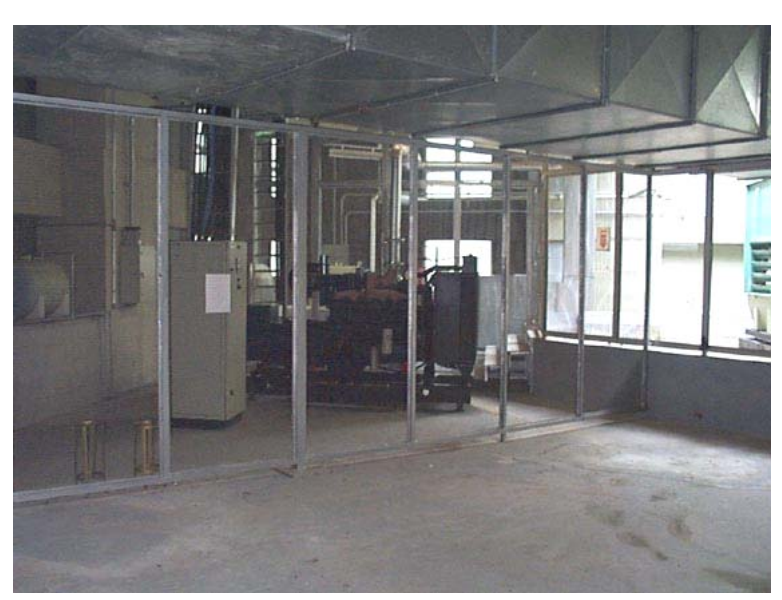




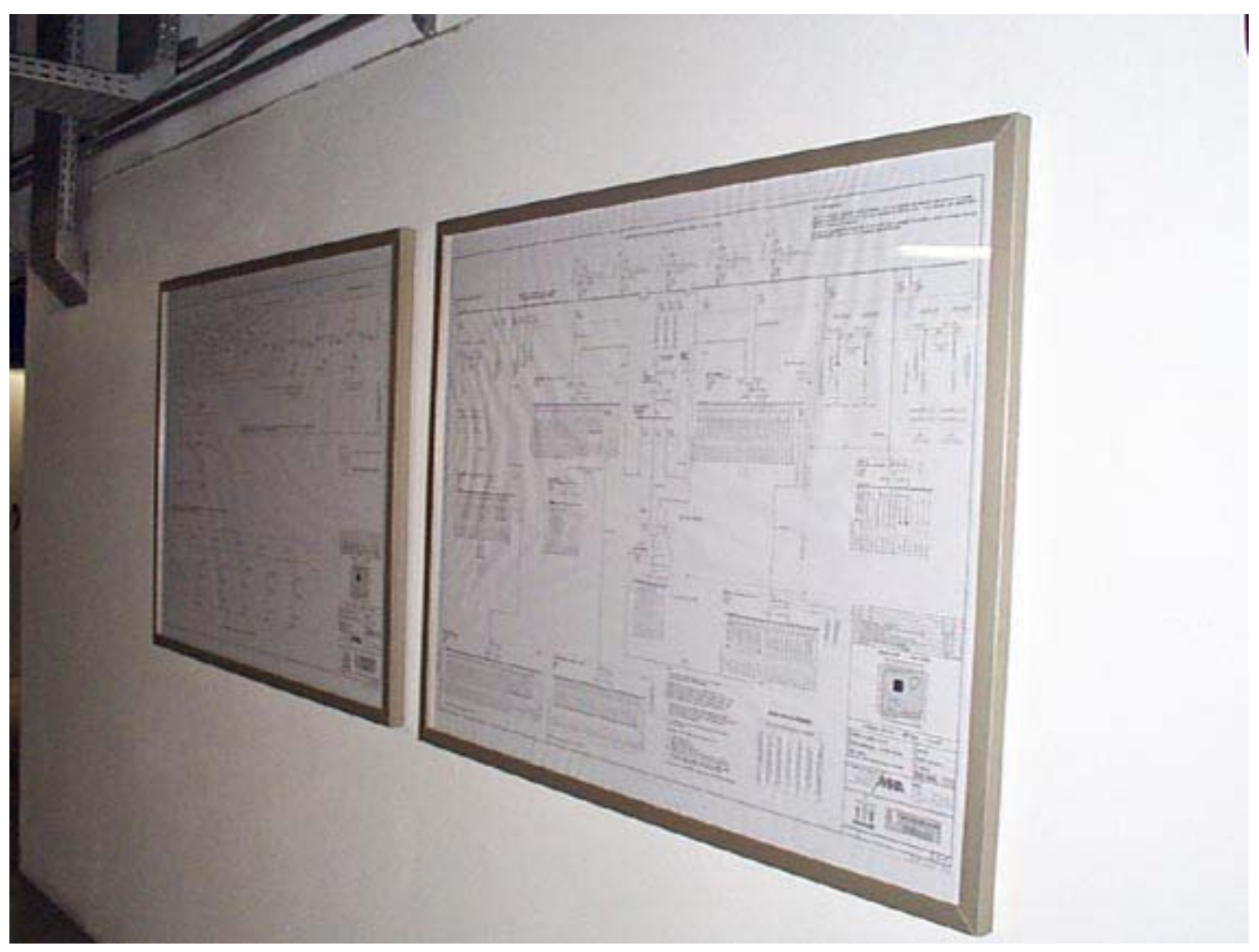

Fig. 111 Projeto Elétrico/iluminação instalado na sala de força facilita a visualização dos pontos de controle - CENU

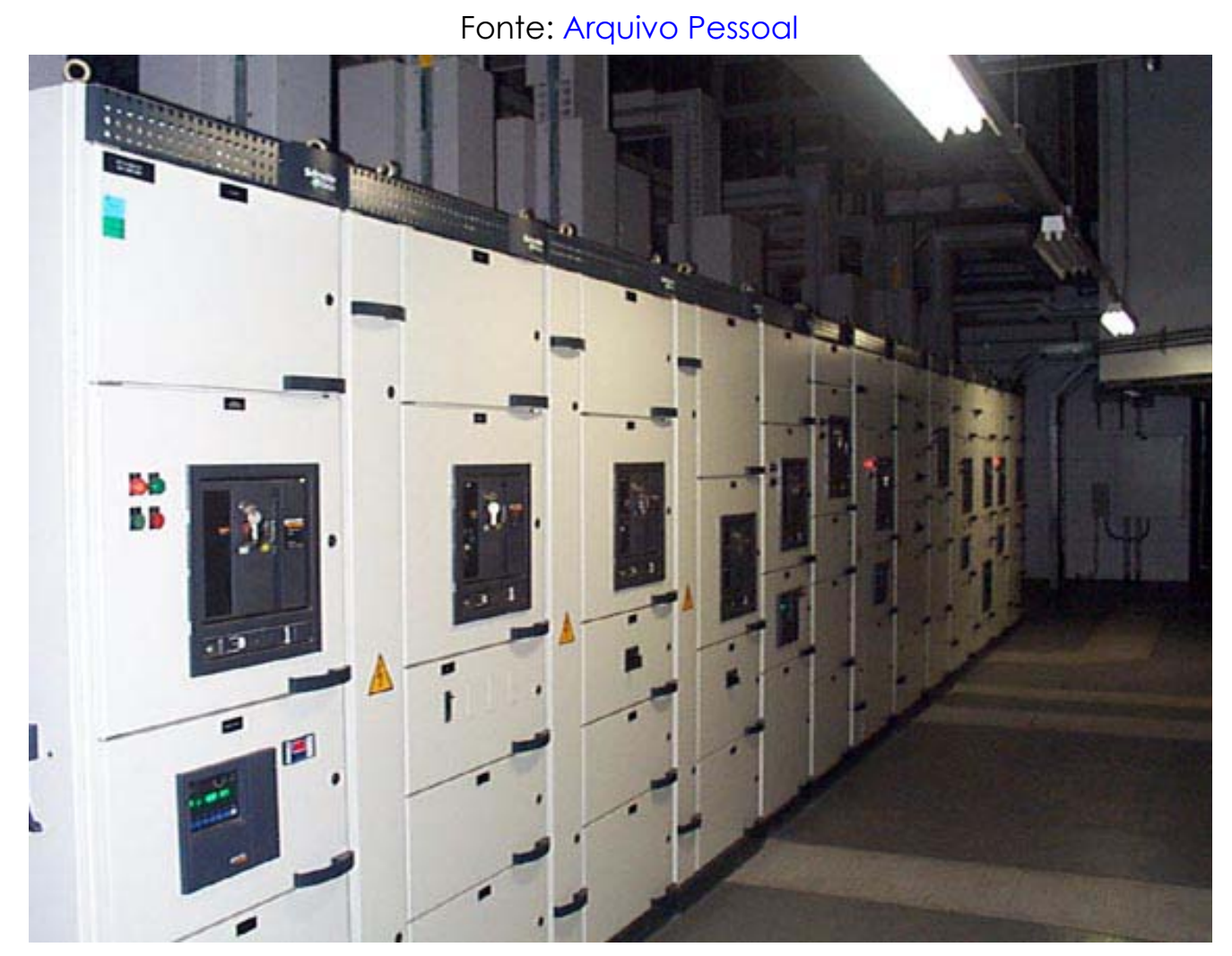

Fig. 112 Sala de força controle total dos 3500 pontos de energia da torre Norte - CENU Fonte: Arquivo Pessoal 


\subsubsection{Hidráulico}

O principal motivo para modernizar as instalações hidráulicas é operacional, como eliminar vazamentos ou modificar a distribuição das tubulações nos ambientes.

Com a aplicação de sistemas de automação predial, pode-se monitorar os níveis dos reservatórios e em função destes providenciar ou não o acionamento de bombas.

Poderá também ser feito o gerenciamento do consumo de água, identificando vazamentos e controlando a acumulação e o despejo de efluentes nas redes públicas, programando-o conforme horários prédefinidos.

O sistema de bombeamento poderá ser monitorado e até as características físico-químicas da água para abastecimento já contam com sistemas de controle (controladores locais de qualidade de água).

Embora os automatismos existentes nas instalações hidráulicas das edificações estejam muito atrás dos equipamentos industriais, a necessidade de acompanhar-se o consumo de água levou à introdução de:

- Medidores microprocessados de consumo de água;

- Controladores microprocessados de bombas;

- Controladores locais de qualidade de água.

Um sistema de automação, quando interligado a esses equipamentos ou mesmo a bóias, pode exercer uma monitoração de níveis de reservatórios e do consumo de água.

\section{Caso - CENU}

Num exemplo típico de aplicação de sistemas de automação predial, este pode monitorar os níveis dos reservatórios e em função destes providenciar ou não o acionamento de bombas.

Fig. 113 Sala de instalações hidráulicas e de incêndio - CENU Fonte: Arquivo Pessoal

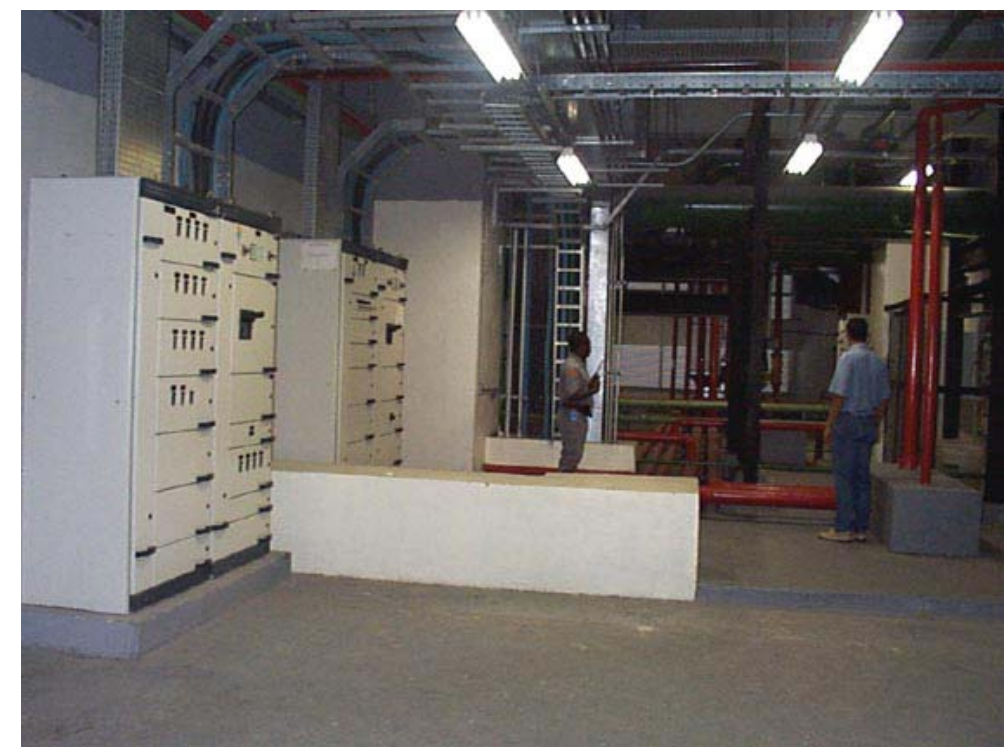




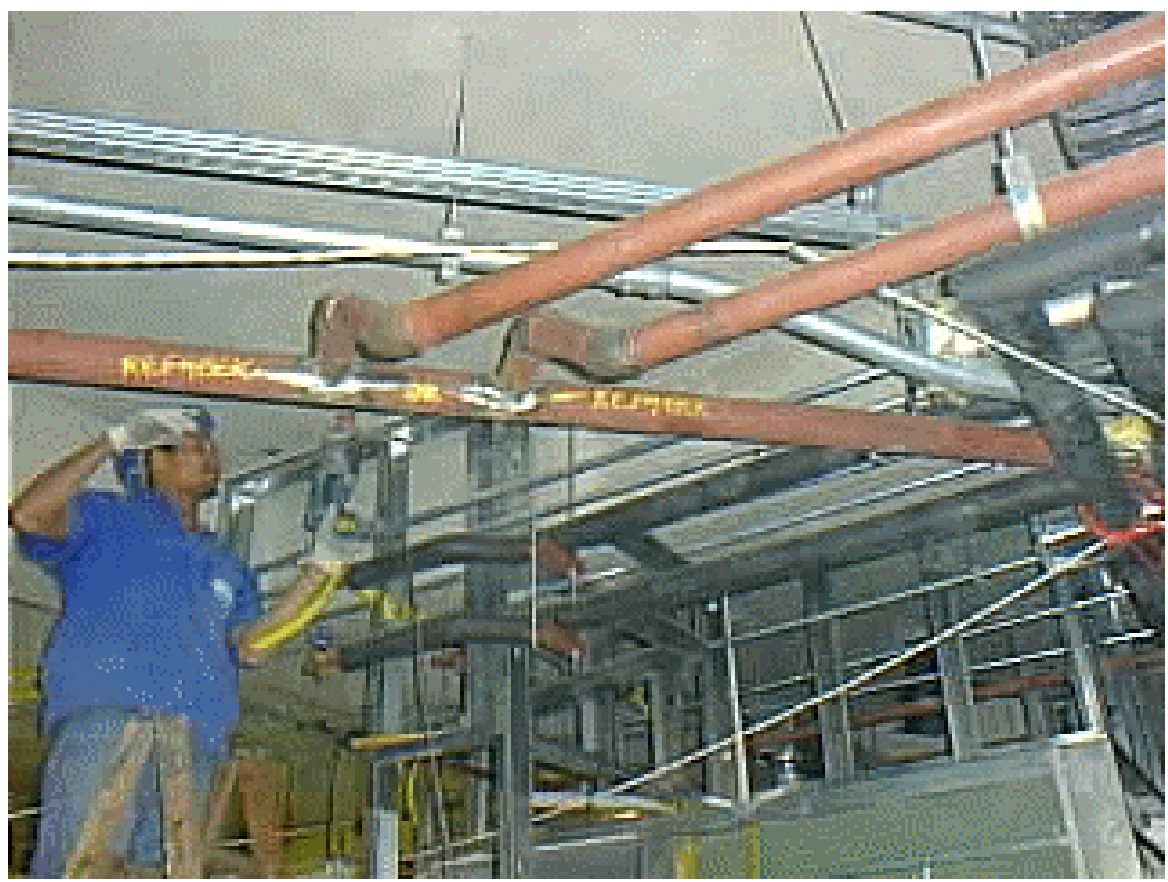

Fig. 114 Instalações hidráulicas do Hilton sob o forro removível - CENU

Fonte: Arquivo Pessoal

As instalações do CENU são geridas por um programa que identifica vazamentos, aciona as bombas dos reservatórios para o caso de baixa nos níveis, identifica entupimentos, avisa a necessidade de manutenção preventiva entre outros.

\subsubsection{Deteç̧ão e Alarme de Incêndio}

A automação também se faz presente na prevenção do fogo de sistemas completamente independentes por força da norma (NBR9441/1993), com centrais e repetidoras microprocessadas, às quais se interligam detectores e acionadores manuais, automáticos ou endereçáveis e com possibilidade de ajuste do grau de sensibilidade de detector remotamente.(Marte 1995)

Entre os principais detectores automáticos de incêndio podem ser citados os de fumaça (ópticos ou iônicos) - detectam a presença de particulado ou fuligem no ar -, os termovelocimétricos - detectam o gradiente de temperatura - e os de chama. Os sistemas convencionais prevêem supervisão de circuitos ou laços de incêndio (grupo com até 20 detectores).

Através da monitoração de chaves de fluxo na rede de Splinkers é possível detectar-se o consumo de água nesta rede. Outras formas são a supervisão e controle sobre as bombas jockey (bomba secundária de incêndio) e bomba de hidrantes (bomba principal).

Em substituição aos tradicionais painéis indicadores de incêndio, muitos sistemas com monitores coloridos exibem, além da identificação do alarme, 
plantas de localização deste e procedimentos aplicáveis, tais como o ramal do brigadista de incêndio daquele andar.

Num exemplo de aplicação de sistemas de automação interligados aos sistemas de detecção e alarme de incêndio é possível:

- Proceder a desenergização destes setores, impedindo que o arcondicionado ou curtos circuitos na rede elétrica alimentem ainda mais o fogo;

- Posicionar os elevadores inicialmente no térreo ou andar mais recomendado para fuga de eventuais ocupantes, posteriormente posicioná-los num possível andar imediatamente acima dos setores atingidos, evitando que o fogo se propague pelo fosso do elevador;

- Através de luminosos e indicadores, estabelecer-se rotas preferenciais de fuga - plano de abandono do local de trabalho;

- Proceder ao insuflamento de ar nas escadas de emergência, impedindo que estas sejam invadidas pela fumaça.

\section{Caso- CENU}

A Torre Norte, incluindo seus subsolos dispõe de um sistema de proteção contra incêndio, tendo sprinklers distribuídos por todo o imóvel. Existem detectores de fumaça espalhados por todas as áreas comuns, sete pull stations por andar e alarmes. Além dos sistemas de detecção, cada andar possui quatro hidrantes e extintores.

A propriedade possui seis tanques de água com capacidade para $750 \mathrm{~m}^{3}$ cada, localizados no quinto subsolo e dois tanques localizados no $36^{\circ}$ andar, um de $740 \mathrm{~m}^{3}$ e outro de $240 \mathrm{~m}^{3}$, reservado para o uso de sprinklers e hidrantes.

O edifício possui quatro escadas de emergência pressurizadas para evacuação em caso de incêndio.

Fig. 115 Identificação dos extintores de incêndio e chave de acionamento de alarme - CENU

Fonte: Arquivo Pessoal

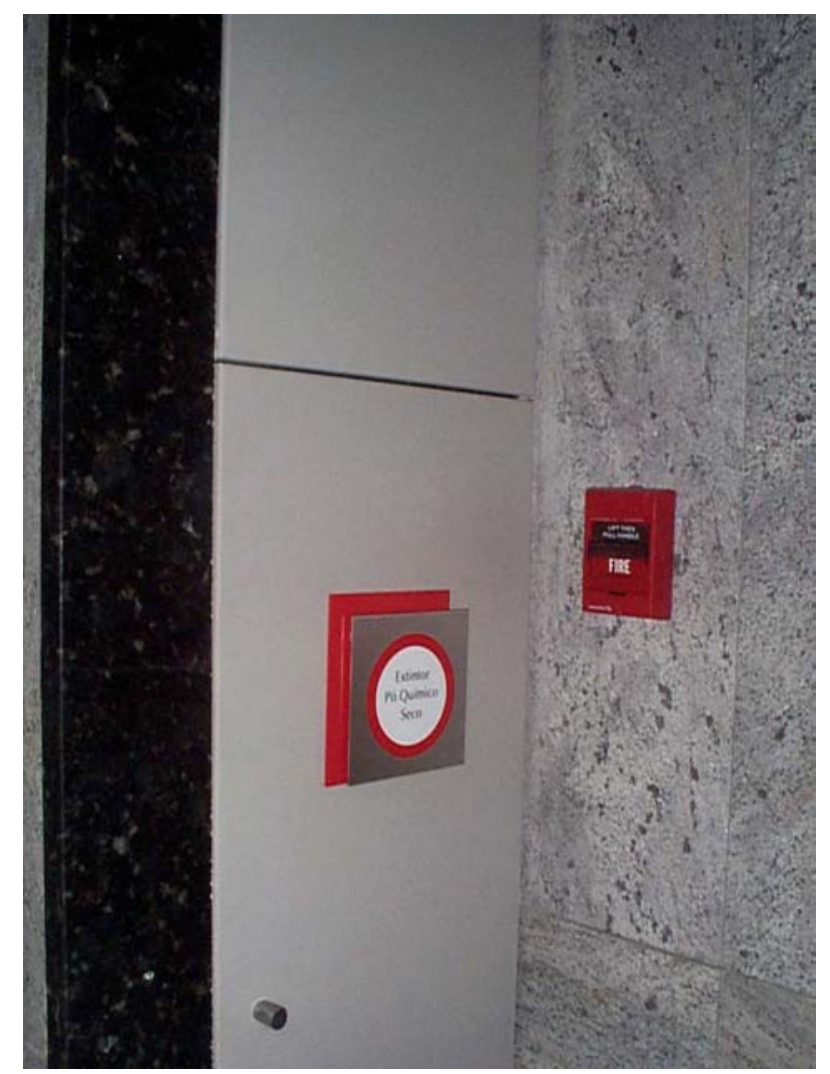




\subsubsection{Condicionamento Ambiental}

Os sistemas de condicionamento de ar representam um item importante nos custos de uma edificação, quer pelos investimentos iniciais necessários, quer pelo dispêndio que provocam ao longo do tempo com consumo de energia e com manutenção das instalações.

O condicionamento do ar consiste no controle simultâneo da temperatura, da umidade, da movimentação e da pureza do ar de recintos fechados. $O$ ar condicionado é geralmente utilizado para proporcionar sensação de conforto às pessoas, mas pode, também, ser necessário para climatizar ambientes cujas atividades requerem controle rígido de uma ou mais características do ar, como ocorre, por exemplo, em certas indústrias, em hospitais, em centros de computação, etc.

Os sistemas de ar condicionado variam desde simples aparelhos de janela até grandes centrais. Os aparelhos de janela são pequenas unidades indicadas para ambientes de pequenas dimensões, funcionando com condensação a ar, estando, pois, aptos a refrigerar o ambiente no verão e a aquecê-lo no inverno pela simples reversão do ciclo de refrigeração.

As pequenas centrais funcionam com condensação a ar ou a água e possuem capacidades variando de 3 a 20 T.R. São unidades compactas que podem aquecer o ar no inverno, tanto pela reversão do ciclo de refrigeração quanto através de resistências elétricas ou com a utilização de água quente ou vapor.

As grandes centrais de ar condicionado localizam-se numa casa de máquinas de onde distribuem $O$ ar para grandes ambientes como teatros, cinemas, restaurantes, etc. As centrais de água gelada são utilizadas em grandes instalações que servem a vários ambientes simultaneamente, mantendo numa casa de máquinas os equipamentos comuns a todos eles, como a torre de resfriamento, o sistema de aquecimento e o sistema de frio, que será distribuído na forma de água quente ou água gelada para "FANCOIL" (Climatizadores) de ambiente.

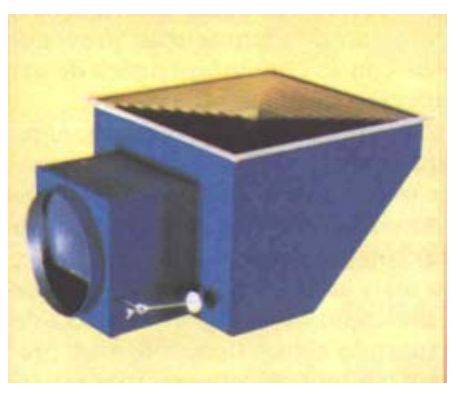

Fig. 116 Funcionamento do Sistema de arcondicionado Fig. 117 Caixa de VAV Fonte: BORGES 1996

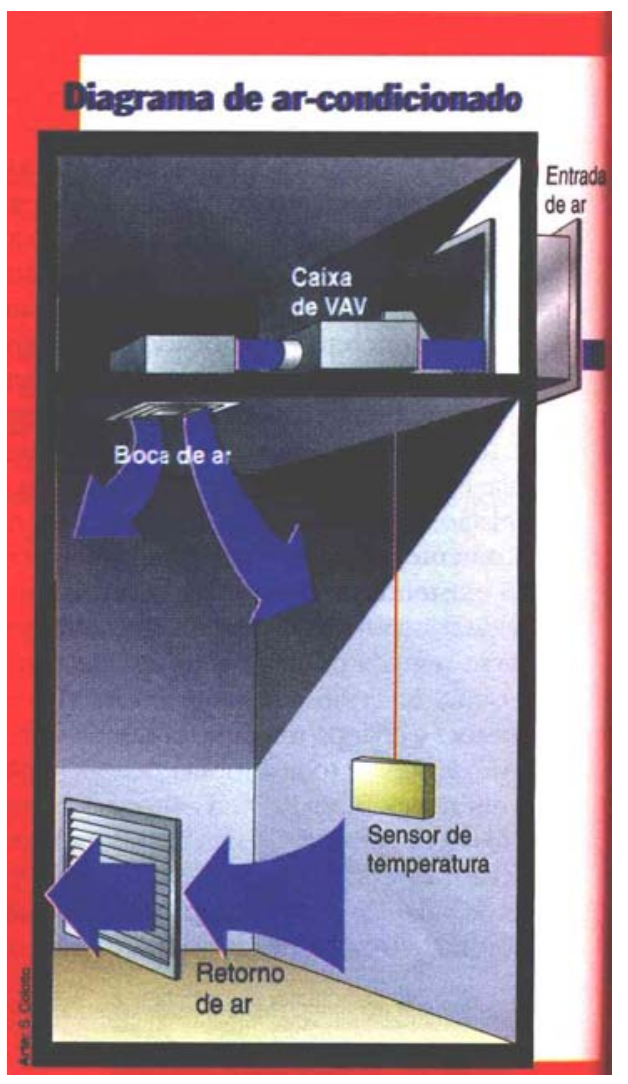


Os aparelhos de ar condicionado são sistemas que consomem, grandes quantidades de energia, quer pelas próprias características dos processos físicos envolvidos, quer pelo uso continuo a que são submetidos durante longos períodos. Por isso, as instalações de condicionamento de ar constituem-se num capítulo importante do programa de uso racional de energia.

Dentre as ações que podem ser implementadas para melhorar o rendimento energético do sistema de ar-condicionado podemos destacar as seguintes:

- Controlar as fontes externas de calor (ou de frio), como insolação e ventilação natural, tirando proveito das mesmas para aumentar ou diminuir a temperatura do ambiente, conforme a época do ano ou os objetivos desejados;

- Regular as fontes internas de calor (ou de frio), otimizando o funcionamento de equipamentos e instalações como motores elétricos, fornos, iluminação e outros, e procedendo ao isolamento térmico de tubulações e depósitos de substâncias aquecidas (ou geladas);

- Regular o sistema para que ele opere em torno da maior temperatura da zona de conforto indicada pelo projetista ou instalador ou dos índices indicados pela ABNT;

- Desligar o sistema sempre que o ambiente estiver desocupado; estudando a possibilidade de desligar $o$ ar condicionado uma hora antes do encerramento do expediente;

- Substituir o ar ambiente pelo ar frio da madrugada para diminuir a carga térmica da edificação;

- Operar somente as torres de refrigeração, bombas e outros equipamentos que forem essenciais à operação do sistema;

- Reduzir o fluxo de ar ao mínimo aceitável em cada área;

- Proceder à manutenção periódica de todo o sistema, eliminando vazamentos e limpando aparelhos de janela, torres de refrigeração, etc...

- Instalar recuperadores de calor, resfriando o ar externo através do ar de exaustão, quando o processo exigir a troca de todo o ar interno por ar externo;

- Utilizar sistema de termo acumulação, com água gelada ou com gelo, para diminuir o consumo de energia com condicionamento de ar nos horários de ponta e reduzir a demanda do equipamento;

- Utilizar $100 \%$ do ar externo quando sua entalpia for menor do que a do ar de retorno, instalando um sistema de controle entálpico;

- Instalar equipamentos de controle de rotação dos motores das bombas de sistemas que usam água gelada para adaptar a vazão às necessidades momentâneas do sistema, reduzindo assim, o consumo de energia de bombeamento. 


\section{Caso - CENU}

O sistema de ar condicionado da Torre Norte conta com uma central de água gelada com capacidade para 2.100 TR, produzida por três torres York de 700TR. Cada um dos pavimentos é dotado de dois faincoils e 18 caixas de volume de ar variável (VAV), correspondentes a 18 zonas de temperatura diferentes por andar.

O sistema permite estabelecer temperaturas entre $20^{\circ} \mathrm{C}$ e $24^{\circ} \mathrm{C}$, conforme as necessidades dos diferentes ambientes ou zonas. Esse cuidado, junto com a automação de todo o sistema, dá ao sistema uma grande flexibilidade e desempenho econômico.

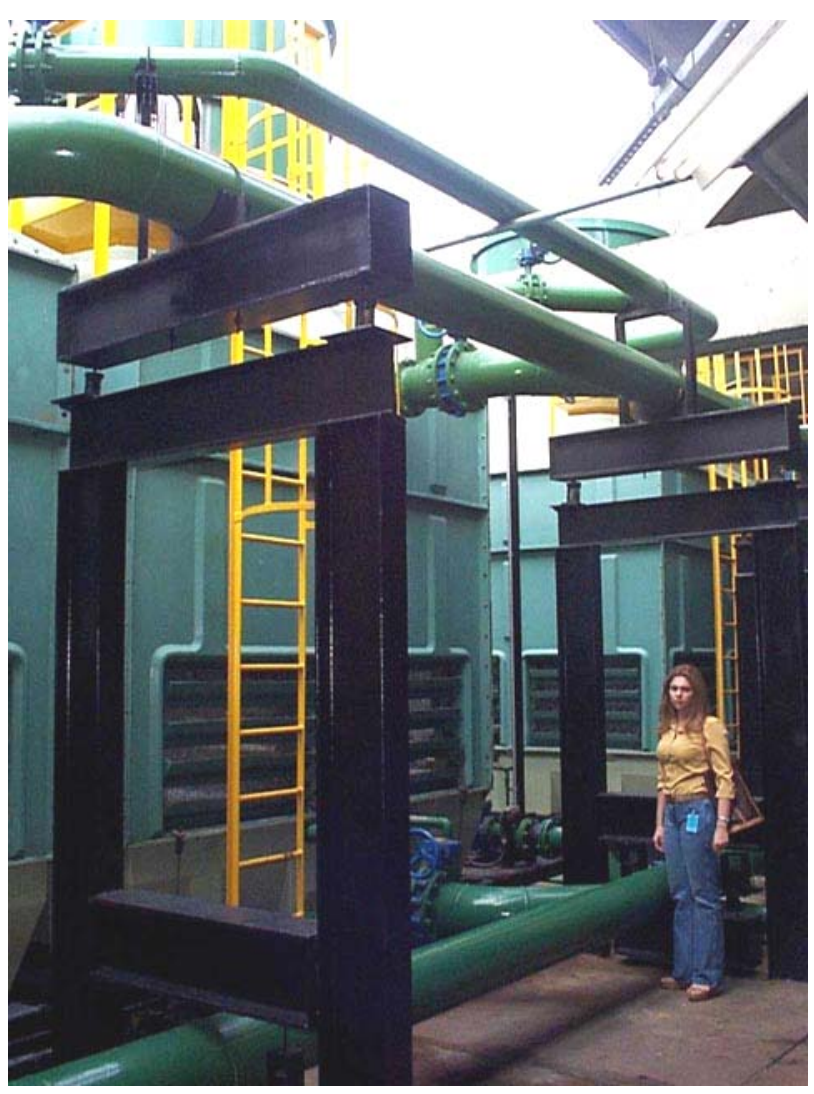

Fig. 118 Torres de Resfriamento - CENU Fonte: Arquivo Pessoal

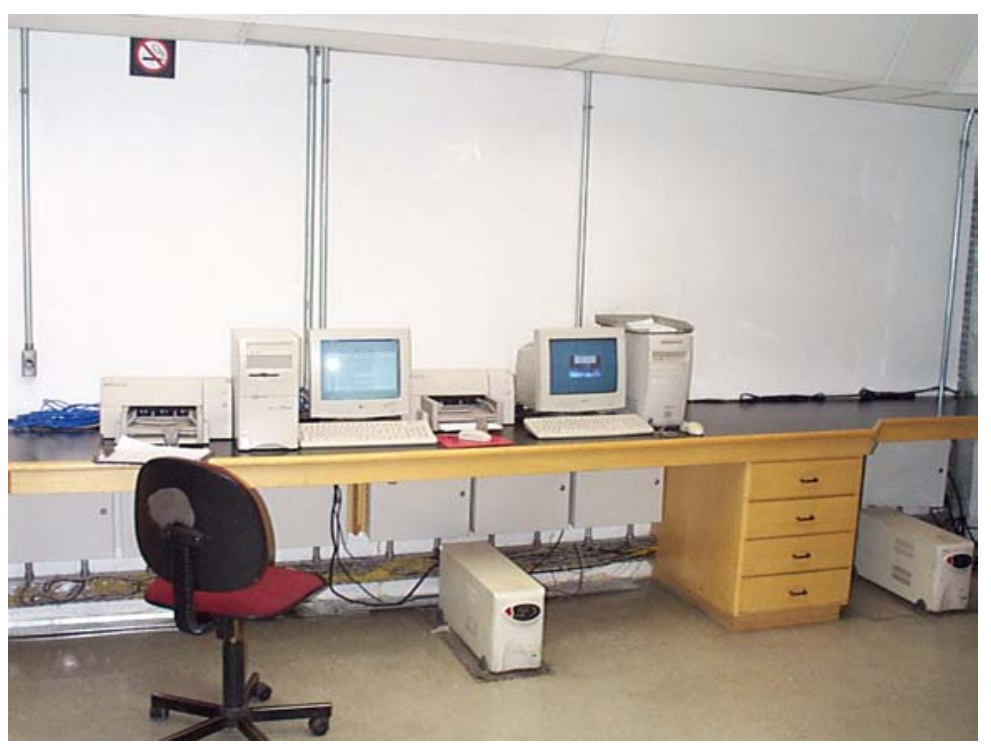

Fig. 119 Central de controle de condicionamento - CENU

Fonte: Arquivo Pessoal

As torres de resfriamento funcionam 24h/dia por dia, o que permite aos condôminos instalarem equipamentos do tipo "self" à água para atender necessidades especiais de consumo.

O nível de ruído do sistema de ar-condicionado nas salas é de NC40. Este índice é praticamente igual ao de um teatro", diz Marcos Matteis, gerente de Engenharia da Tishman Speyer, empresa que responsável pelo do projeto. 


\subsection{Telecomunicações / Redes}

Ainda hoje é comum a concepção de edifícios com modernas tecnologias de Arquitetura, de aparência marcante, mas sem uma infra-estrutura de recursos e espaços necessária para fazer com que eles sejam funcionais e inteligentes.

Para atender a todas as necessidades de telecomunicações de um edifício, o ponto mais importante é o correto dimensionamento dos espaços e percursos destinados a utilização da cabeação estruturada.

A infra-estrutura de telecomunicações sempre deve ser concebida juntamente com o projeto arquitetônico, realizando a alocação dos espaços de maneira eficiente e adequada. Na maioria dos casos os edifícios convivem com eternas deficiências em seu funcionamento, devidas à falta de preocupação dos profissionais da construção civil com os sistemas de telecomunicações.

Um edifício moderno e funcional não precisa ser automatizado desde o início de seu funcionamento, mas ele deve obrigatoriamente ter sido projetado com toda a infra-estrutura de espaços de maneira a permitir que todo e qualquer sistema de telecomunicações seja implantado no seu interior de maneira adequada.

Portanto, independente dos sistemas que serão implantados desde a sua inauguração, o dimensionamento dos espaços e percursos da infra-estrutura de telecomunicações deverá ser feito de maneira abrangente, com soluções dinâmicas e não específicas.

Os edifícios "inteligentes", imóveis que agregam recursos de alta tecnologia na gestão predial, formaram um conceito segundo o qual é possível à edificação incorporar inovações com certa facilidade a qualquer tempo. Mas para prover os usuários dessa versatilidade, o projeto deve servir-se hoje da pré-cablagem, também conhecida como cabeamento estruturado ou cables systems. A pré-cablagem é utilizada para interligação de sinais elétricos de baixa intensidade, tais como transmissões de voz (telefonia), imagens (videoconferência), dados (comunicação entre microcomputadores) e gestão técnica dos empreendimentos (automação de sistemas de segurança patrimonial, incêndio etc.)

Podemos dizer que existem duas formas básicas de distribuir os cabos para alimentação dos sistemas de dados, voz, vídeo e automação de uma edificação. A primeira, pelo método convencional, adota sistemas rígidos e fixos. Esses sistemas, bastante conhecidos, não permitem flexibilidade nas conexões - caso dos cabos de telefonia, desaconselhados para a comunicação de dados - e não admitem mobilidade no momento de alterar o layout do ambiente, podendo exigir a presença de técnicos externos de manutenção, além da interrupção da rotina de trabalho e dos custos a cada alteração de projeto. A esses inconvenientes acrescente-se a 
deterioração das instalações pela manipulação inadequada. No caso dos cabos de comunicação, por exemplo, é grande o risco de aumento de ruídos pela mudança de suas características elétricas. A segunda opção, o cabeamento por sistemas flexíveis, permite realizar a mudança de um posto de trabalho (com microcomputador, telefone e até sinal de vídeo) em uma dezena de minutos, tornando o layout variável conforme a necessidade dos usuários.

As instalações de cabeamento estruturado apresentam custo de implantação superior ao de sistemas convencionais. Apesar disso, trazem as vantagens da flexibilidade e da modularidade, evitando-se assim os inconvenientes de uma reforma no ambiente de trabalho. Trata-se de um sistema de "Arquitetura aberta", capaz de suportar topologia de redes estruturadas dos tipos anel (ring), estrela (star) e barramento (bus), e, embora seja uma tecnologia nova, já dispõe de normas e padrões internacionais, que exigem níveis de desempenho do sistema e das características elétricas dos aparelhos conectados.

Podemos conceituar o cabeamento estruturado como uma estrutura composta por um conjunto de conectores e cabos dispostos, interligados e testados segundo normas técnicas de um projeto de engenharia. As fiações, prumadas e redes de distribuição são reunidas em um único sistema, construído de forma modular, com a utilização de componentes universais, permitindo a reconfiguração de qualquer um deles, sem a instalação de um fio sequer, apenas com a reconexão de alguns cabos.

No interior de uma edificação, cada área ou ambiente possui características individuais de layout, situações definidas por vários fatores, tais como divisórias, equipamentos utilizados, concepção do projeto arquitetônico de interiores, número de postos de trabalho, tipos de paredes e pisos etc. A função do cabeamento estruturado é facilitar - por meio de topologias lógicas e múltiplas - as modificações do layout dos postos de trabalho, dando-lhes o máximo de flexibilidade. Além da rapidez nas alterações e do baixíssimo custo, outro fator importante é que este é um meio confiável, que comporta qualquer rede de computadores (microcomputadores), qualquer topologia (sistema de hardware, software, protocolos e conexões necessárias para a comunicação) e elevada velocidade de transmissão.

Basicamente, são três os atributos do sistema de cabeamento estruturado:

- Universalidade - capacidade de atender a qualquer sistema ou equipamento

- Perenidade - possibilidade de atender às necessidades atuais e futuras com garantias de até 15 anos para equipamento e cinco para evolução do sistema

- Flexibilidade - atendimento a qualquer layout proposto 
Os sistemas convencionais predominaram até meados dos anos 80. Em 1985, começaram a surgir sistemas para atender a necessidades específicas de comunicação de dados (desenvolvido pela IBM) e de telefonia (pela AT\&T). A integração de ambos iniciou-se em 1987, com a parceria entre as empresas francesas Infra e BCS, resultando na IBCS. A partir de 1990 tem início o conceito de modularidade das conexões com a AMP, norteamericana, e a Infra (nova razão social da IBCS).

Atualmente, os sistemas trabalham com cabos metálicos capazes de levar a informação a uma velocidade de até $155 \mathrm{Mbps}$ (milhões de bits por segundo - UTP/FTP nível 5), embora na média atuem a 100 Mbps. Eles podem ser utilizados na distribuição horizontal e vertical dos sistemas. Mas há também a fibra ótica, recomendada para interligações entre prédios e, de acordo com a aplicação, na distribuição vertical. A principal restrição ao uso dessa tecnologia é o alto custo de ligação das interfaces óptica e elétrica, que exige um transdutor capaz de transformar a luz em impulsos elétricos e viceversa.

Em fase de homologação há cabos elétricos para atuar a $622 \mathrm{Mbps}$ em aplicações para TV a cabo, por exemplo. Para os próximos cinco anos teremos o conceito FTD (Fiber To Desk), isto é, fibra até a mesa, com as interfaces óptica e elétrica de baixo custo, tecnologia já utilizada, por exemplo, nos CD players que temos nos equipamentos de som. Quer dizer, o mercado brasileiro já dispõe de acessórios que facilitam a manipulação e alteração de sistemas. Por isso, a reforma (retrofit) de uma instalação e a adoção de cabeamento estruturada é hoje plenamente viável, apresentando ótima relação custo/benefício. Basicamente, o cabeamento estruturado contribui para a redução das reformas nos edifícios, possibilidade de uso de várias tecnologias, facilidade de alterações dos cabos de interligações (path-cords nos bastidores), adoção de uma sistemática de mudanças baseada em ordens de serviços que são geradas com dados da documentação (mantendo-se assim a documentação atualizada) e identificação de todos os elementos que permitem um melhor controle.

\section{Caso - WTC - SP}

O World Trade Center de São Paulo é um bom exemplo de empreendimento que adotou o cabeamento estruturado. Para atender a demanda, o complexo dispõe de salas exclusivas de equipamentos para as concessionárias Telesp e Embratel (rádio e dados), entroncamento com rede pública em fibra ótica, central de PABX CPA do tipo DDR (processo de estabelecimento de chamadas pelo qual o usuário da rede pública tem acesso direto aos ramais sem auxílio da telefonista), sistemas de videoconferência e de Pager privado.

Basicamente, a instalação completa-se com 2,5 mil tomadas de nível 5 e mais de mil tomadas de nível 3 (telefonia), totalizando cerca de 3,6 mil módulos. Os cabos metálicos de nível 5 (com 25 pares no cabeamento vertical e 4 no horizontal) percorrem $97 \mathrm{~km}$, e os de nível 3 perfazem 21 km, 
além de $5,5 \mathrm{~km}$ de fibra ótica. Todo esse cabeamento chega a um único distribuidor interno (DI) por andar, capaz de atender a 100 postos de trabalho.

O estudo de viabilidade de um projeto desse porte recomenda, primeiro, uma previsão dos sistemas de voz, dados, imagens e outros. desejados pelo cliente e depois o desenvolvimento do projeto. A definição de cada sistema segue um roteiro que parte da análise do negócio, definição das funções desejadas, elaboração do anteprojeto executivo (com especificações de equipamentos, instalações e procedimentos para testes funcionais) e padronização de planilhas (para que todas as empresas utilizem a mesma terminologia). $\bigcirc$ WTC também foi didático neste aspecto. As dificuldades residiram exatamente na documentação (antes e durante a implementação), inexperiência

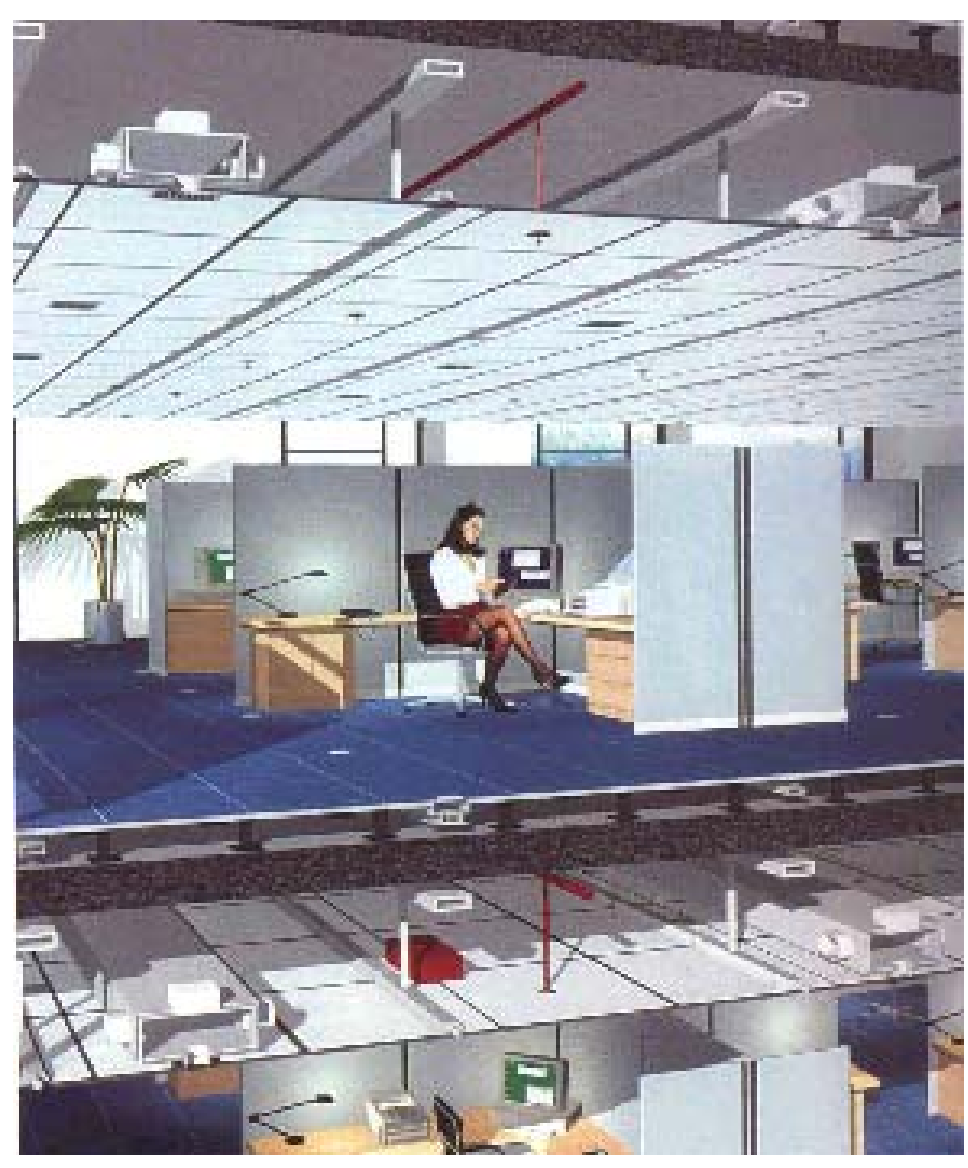
instaladores, falta de material complementar (importado), falta de normalização de referência na fase de projeto arquitetônico e ausência de sintonia entre incorporadores, construtores, arquitetos e operadores.

Fig. 120 Esquema de passagem do cabeamento estruturado

Fonte: Revista Téchne out 2001 no 55

Superados esses problemas, vieram os benefícios: agilidade na operação, simplicidade no controle, flexibilidade para a entrada de novas tecnologias, qualidade e confiabilidade das instalações. Para isso, foi importante o trabalho de gerenciamento na fase de implantação e a determinação da sistemática de testes funcionais. Esta etapa contou com controle de testes por meio de "fichas de verificações", com tópicos como aceitação visual, documentação de identificação para cabos e componentes, verificação de amarras, curvas, terminações e conexões, além da aprovação definitiva com testes elétricos, óticos e de desempenho. 


\subsection{Segurança}

Os sistemas de segurança foram inicialmente introduzidos com a finalidade de proteger as pessoas e propriedades dos intrusos. Desenvolvimentos posteriores permitiram a estes sistemas a realização de outras tarefas de segurança tais como detecção de incêndio, monóxido de carbono, radiações e outros perigos.

Os sistemas de segurança de hoje em dia podem fazer mais do que proteger edifícios e pedir ajuda. Numa rede de comunicações de dados utilizada para este fim, os mesmos sensores que detectam movimento, fogo, ou líquidos, podem ser utilizados para ativarem um número variado de ações. Utilizando a interface do sistema de segurança, podemos controlar a iluminação, portas, janelas, grades, e outros sistemas no edifício.

O sistema de segurança pode enviar sinais para ligar e desligar a iluminação de acordo com os estado dos detectores de movimento e toda a programação de integração do sistema.

Vejamos agora algumas das possibilidades do sistema de segurança:

\section{Verificação dos Sistemas de Controle}

Todos os sensores de acesso e atuadores estão ligados a microcontroladores, os quais por sua vez estão ligados ao controlador geral de gestão do edifício. Para além das redes digitais de computadores, podem ser introduzidos sistemas de circuito fechado de vídeo, os quais necessitam de sistemas de comunicações tais como par trançado coaxial ou fibra óptica para transportar a informação.

\section{Monitoração Remota de Alarme e Imagem}

O serviço de monitoração consiste no controle do local protegido durante 24 horas por dia pela Central de Monitoramento. O controle é feito remotamente através de comunicação telefônica.

No exato instante da chegada do sinal telefônico, o computador da Central de Monitoramento prioriza na tela todos os procedimentos, previamente determinados pelo sistema cliente, que farão com que o operador tome as providências necessárias para cada situação.

A Central de Monitoramento controla o "status" do sistema durante 24 horas por dia. Todos os sinais vitais do sistema são controlados: possível falta de energia elétrica, bateria de backup com carga baixa, falta de sinal de teste diário, etc. Para qualquer problema técnico no sistema é automaticamente aberta uma ordem de serviço para verificação. Esse controle é muito importante, pois de nada adianta ter um excelente sistema de alarme, se ele não estiver operando normalmente quando se precisar dele. 
Além disso, a Central controla a proteção do local em si. A qualquer momento do dia é possível saber, por exemplo, se o alarme está armado ou desarmado. O tempo entre o disparo do alarme e a visualização do evento na tela do supervisor remoto varia em média 20 segundos.

O supervisor pode dispor ainda de uma pequena planta do local protegido, - que permite o acompanhamento da área onde está ocorrendo um alarme. Qualquer violação nos equipamentos e na fiação é classificada como emergência policial.

É possível também, periodicamente, a obtenção de um relatório computadorizado contendo todos os eventos do período, como horário de abertura e fechamento (informando nome do usuário), eventuais emergências, disparos, violações, possíveis falhas na comunicação, bateria fraca, etc.

Os sistemas de CFTV são compostos por câmeras ou microcâmeras ligados a um monitor ("televisão"). Em sistemas a partir de 2 câmeras é necessário utilizar um equipamento especial para que seja possível visualizar mais de uma imagem no mesmo monitor. Existem várias opções para colocar as imagens de até 16 câmeras em um mesmo monitor. $O$ sistema pode ter imagem em P\&B ou colorida, dependendo do objetivo.

Fig. 121 Microcâmera

Fonte: http://images.google.com

Também é possivel utilizar lentes especiais que fazem 0 efeito de zoom, ou ainda colocar um "motor", que faz com que uma câmera possa girar a procura de um alvo.

Além de imagem, o sistema pode

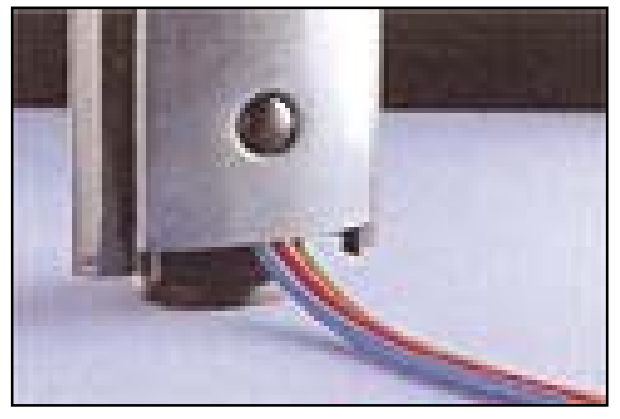
eventualmente incluir áudio embutido nas câmeras, porém, vale lembrar que ao contrário das imagens, só é possível gravar ou monitorar um sinal de áudio de cada vez.

Existe a possibilidade de utilização de câmeras sem fio, com alcance aproximado de $40 \mathrm{~m}$ em área aberta. Porém esse é um sistema pouco flexível e recomendado somente para casos especiais ou projetos de pequeno porte.

As imagens geradas pelo Circuito Interno podem ser gravadas com um videocassete comum ou profissional (que permite gravar até 960 horas em uma mesma fita VHS T120). Também podem ser transmitidas via telefone para uma central de monitoração ou para um computador cliente.

Na maioria dos casos, o sistema de CFTV é utilizado em conjunto com um sistema de alarme, para que se possa ter um controle eficaz do local protegido. Hoje, $95 \%$ dos sistemas de CFTV comercialmente disponíveis são analógicos e se conectam em padrões de Vídeo composto PALM ou NTSC PB ou ainda Color IVpp 75ohms. O sistema mais simples de CFTV é composto 
por uma câmera conectada diretamente a um monitor. Como exemplo pode-se citar o Vídeo Porteiro onde alguns ainda oferecem a função de campainha e destravamento de Porta.

O segundo sistema é composto por um monitor que visualiza " $n$ " câmeras, uma de cada vez, através de um equipamento seqüenciador, onde podemos programar o tempo de varredura entre as câmeras.

A terceira configuração emprega um equipamento MUX que permite dividir a tela do monitor de 4 até 16 partes, sendo que cada parte corresponde à imagem de uma câmera em tempo real. Algumas MUX podem selecionar uma câmera para monitorar toda a tela. Porém é recomendado o uso de um monitor maior ou projetor para salas de monitoramento. Também existe opção de MUX dual Quad, que alternam 8 câmeras apresentando 4 câmeras por vez no monitor e são mais econômicas.

A monitoração remota de um sistema de CFTV pode ser feita em várias modalidades. No modo mais econômico (e talvez o mais eficaz), são enviados para a central alguns "quadros" de imagens capturadas ao longo do dia em um horário pré-definido ou após o disparo de um alarme. Outra opção é o controle contínuo do local através da recepção de "quadros" de imagens a cada 15min (ou um tempo definido no sistema cliente). E por último existe a monitoração em "real time" (tempo real) que mantém a imagem do local disponível continuamente na Central. Apesar de parecer ser a mais eficiente, o custo x benefício desta última opção não é muito interessante.

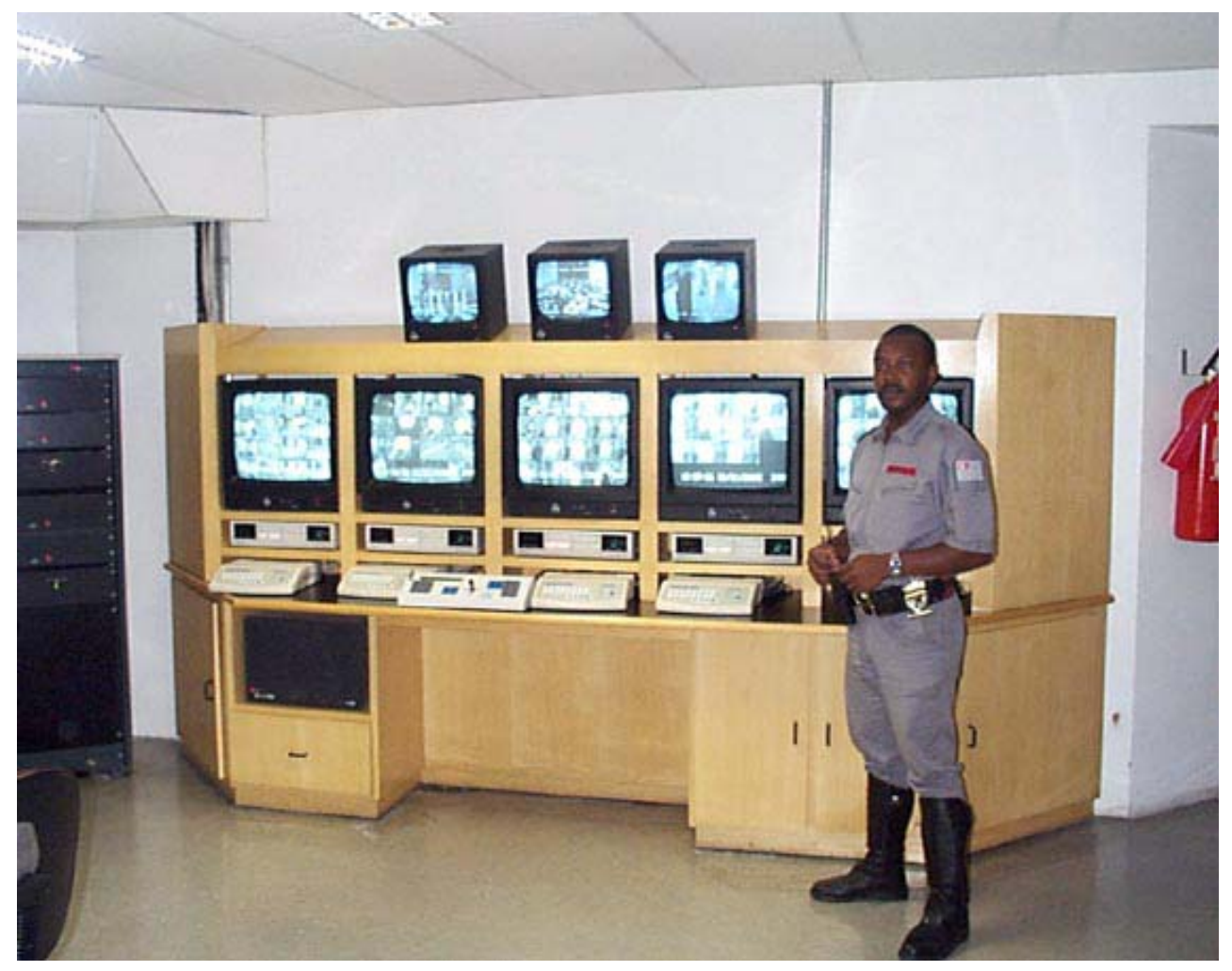

Fig. 122 Sala de controle das Câmeras - CENU SP fonte: Arquivo Pessoal 
Existe também a possibilidade da monitoração ser feita pelo cliente, através do envio das imagens para um computador PC. Também é possível armazenar as imagens digitalizadas no disco rígido. Pode-se consultar um banco de imagens gravadas e controlar horários. Em sistemas mais sofisticados é possível ao operador, remotamente, executar comandos no local que está sendo monitorado, como rotacionar uma câmera, executar um zoom, acionar uma luz, etc. Falar em circuito fechado de televisão até bem pouco tempo parecia uma estória de ficção. Hoje, entretanto, qualquer pessoa pode ter um ótimo sistema de CFTV (Circuito Fechado de TV) em sua casa, loja ou empresa, a um custo mais acessível do que se imagina. Muitas pessoas já aderiram ao CFTV e descobriram as vantagens de trabalharem mais tranqüilos com a vigilância eletrônica. Vários estabelecimentos de pequeno e médio porte estão utilizando o CFTV, principalmente, para se proteger de furtos e até para gerar provas para demissão por justa causa.

Muito utilizado também em condomínios residenciais, o sistema de CFTV permite ainda a gravação das imagens durante 24 horas por dia em fita de vídeo comum (T120). Os equipamentos recomendados para $O$ armazenamento das imagens são VCR especiais chamados LAP SED TIME que armazenam até 960 horas de imagens colhidas entre 2 a 5 frames por segundo. Podem ser empregados VCR'S comuns, todavia em função da aplicação, podem ser antieconômicos.

Existem também CFTV com monitoramento de longa distância (maior ou igual a $500 \mathrm{~m}$ ). Podem ser feitos através de linhas privativas usando cabos coaxiais de $75 \mathrm{ohms}$, com repetidores telealimentados para imagens em tempo real ou via rádio com banda de $4 \mathrm{Mhz}$ desde VHF até microondas.

O Monitoramento de longa distância, através de linhas telefônicas privativas ou comutadas, exige equipamentos que fazem a digitalização, compactação e modulação das imagens para envio sobre estas linhas.

Em linhas privativas até $6 \mathrm{Km}$ de distância, dependendo da qualidade do equipamento e usando modernas ADSL, pode-se obter imagens full size em tempo real. Já em linhas comutadas, a máxima velocidade é $56 \mathrm{Kbps}$ e pode se obter imagens com razoável definição a 5 FPS utilizando um ótimo sistema de digitalização.

Vale lembrar que a partir do momento que empregamos imagens digitalizadas, podemos empregar câmeras digitais que apresentam custo menor, mas tem a obrigação de ficar próximas do equipamento (poucos metros). Uma vez digitalizadas e compactadas as imagens podem ser conduzidas em qualquer protocolo operante em uma intranet ou sobre protocolo IP na Internet.

Do ponto de vista de armazenamento, as imagens digitalizadas e compactadas podem ser gravadas em fita magnética (Stream), em discos rígidos ou discos ópticos regraváveis, que representam um custo bem menor. 
A automação dos processos de CFTV atualmente emprega detectores de movimento, para então fazer a gravação (economiza armazenamento). E num futuro bem próximo, a automação dar-se-á através do reconhecimento de imagens por softwares especializados que determinarão as ações a serem tomadas.

Estes softwares podem reconhecer pessoas através de silhueta, identificar através de íris, impressão digital e padrão vocal, além de tomar decisões como vedar o local, disparar alarmes, acionar dispositivos de defesa (fumaça, gases, etc).

\section{Controle de Janelas ou Portas}

O controle de janelas e/ou portas poderá ser feito pelo PC (Master). A sua elevação ou fecho poderão ser programados de acordo com alguns critérios tais como:

- Quantidade de luz necessária

- Estação do ano

- Horário de funcionamento

- Temperatura ambiente desejada.

\section{Sistema de Detecção de Incêndios}

O sistema de detecção de incêndios pode ser implementado num computador com o auxilio de detectores de fumo, gás e sensores de temperatura. O sistema monitora o estado dos detectores distribuídos por todo o edifício. O edifício estará dividido por zonas supervisionadas pelos detectores. Perante uma situação de incêndio, quando um detector passa ao estado de ativado, o sistema de gestão do edifício tem de identificar imediatamente de qual se trata e qual a sua localização exata, para poder informar os Bombeiros.

A ativação do sistema de mecanismos de alarmes convencionais é realizada, mas adicionalmente, o controle inteligente do edifício ocupar-seia de desligar todos os ventiladores do edifício, emitir uma mensagem digitalizada de alarme para todos os pisos, informando as pessoas da situação e estado do incêndio detectado, a localização e monitoração do mesmo, e ainda quais as saídas de emergência a serem utilizadas. Hipoteticamente, poderia ser feita a digitalização das imagens do fogo, captadas pelas câmaras do circuito interno de vídeo, enviando-as por fax com informação adicional para locais pré-definidos. Também poderia mandar imprimir nas impressoras, planos detalhados do edifício onde incêndio esta e por onde possa propagar, para assim facilitar a ação dos bombeiros. Finalmente poder-se-ia acender a iluminação de todo o edifício com o mesmo fim. 


\section{Intrusão}

Pode-se compreender o conceito de segurança física de um edifício, como o controle de acessos e a detecção de intrusão. O sistema utilizado para o controle de acessos pode ser um cartão de segurança, utilizando um simples cartão magnético, um Smart Card, um sensor de ocupação, voz, impressões digitais, ou leitores de retina. Os últimos três ainda são muito dispendiosos e só são utilizados em instalações especiais. Todo o acesso ao edifício poderá ser controlado por portas automáticas consecutivas.

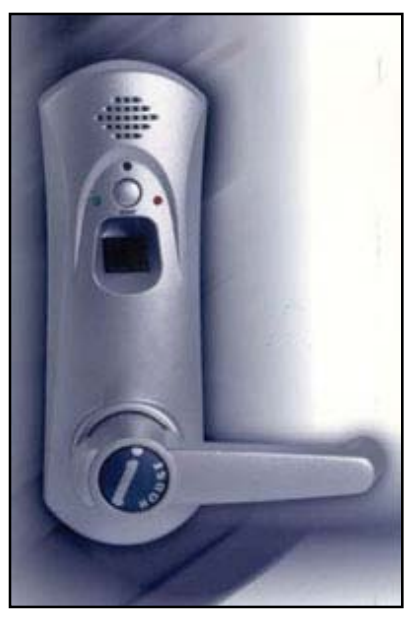

Fig. 123 Fechadura High Tech com sistema de códigos

Fonte: http://images.google.com

O automatismo de acesso poderá ser feito utilizando duas portas consecutivas, com um detector volumétrico entre elas, que automatiza a abertura ou fecho das portas. O controle terá de fornecer um tipo de permissão para abrir a primeira porta, que poderá ser do tipo de leitura de cartões magnéticos. Este sistema poderá ser complementado, conforme o grau de segurança que se queira dar ao prédio, com a ajuda do circuito interno de vídeo, que no momento da entrada de um indivíduo digitalizará essa imagem, enviando-a para O PC (Master), onde ela ficará armazenada juntamente com o código do cartão, data, hora, etc. Todos estes sistemas podem ser controlados pelo gestor de segurança através dos sistemas de controle do edifício.

Para um ótimo controle de acessos, poderá ser implementado, em conjunto com detecção de impressões digitais e código de acesso de quatro algarismos, uma leitura e certificação de um cartão magnético. Existem dois tipos de cartões: Cartões Magnéticos, (utilizam uma banda magnética para armazenar informação) e Cartões de circuito integrado, (utilizam um chip para realizar a mesma operação).

Smart cards são cartões padronizados tipo cartão de crédito com um chip microcomputador embutido. Eles podem ir desde os simples cartões com chip aos sofisticados cartões com microprocessador. Existe tecnologia Smart Card desde 1987 sendo utilizada em todo o Mundo. São utilizados como cartões de saúde, cartões de telefone, TV a cabo, decodificadores de variados sistemas, cartões de crédito e muito mais.

A tecnologia de Smart Cards pode ser dividida em dois tipos: chips de memória com grande proteção utilizando células de memória não voláteis e chips com microcontroladores com um pequeno número de características especiais (hardware e software) necessárias para aplicações Smart Card.

O cartão de memória é utilizado para aplicações simples tais como cartões telefônicos, onde o chip tem 60 ou 120 células de memória, uma para cada unidade telefônica. A célula de memória é limpa cada vez que é gasta uma unidade 'período'. No fim da utilização do cartão, quando as células de 
memória estão todas limpas, ele não é reutilizável. Esta tecnologia é utilizada em aplicativos de baixo valor.

Os cartões com Microprocessador, isto é a alta tecnologia dos Smart Cards, contêm um chip microprocessador, que controla o acesso à informação contida no mesmo. O microprocessador verifica a autentificação do utilizador pelo código PIN (Personal Identification Number), antes de permitir - acesso aos serviços prestados pelo cartão. O chip tem sensores de segurança física e usa algoritmos de criptografia para proteger a informação armazenada ou transmitida de acessos fraudulentos.

A Biometria permite a identificação de uma pessoa (portador do cartão) pela análise das características físicas tais como voz, impressões digitais, etc. A Biometria só é utilizada em terminais sofisticados, com o intuito de controlar acessos a edifícios de alta segurança. Estes sistemas não são utilizados com freqüência devidos aos grandes requisitos computacionais que nos dias de hoje ainda são muito caros.

A existência de sistemas de teste que combinam tecnologias Biométricas e Smart Cards ainda não são satisfatórias, visto o processo de comparação ser realizado nos terminais, expondo os dados de comparação e referências pessoais a possíveis cópias ou fugas de informação. Um nível mais alto de segurança pode ser garantido se o processo de comparação for realizado num dispositivo seguro, tais como Smart Cards. Domain Dynamics Ltda desenvolveram algoritmos biométricos que podem ser utilizados no reconhecimento de sinais periódicos com largura de banda limitada, tais como a voz. O ponto forte desta tecnologia não é reconhecer o contexto da mensagem, mas sim diferenciar uma pessoa de outra. Os algoritmos DDL's são particularmente robustos e permitem a identificação dos utilizadores mesmo quando a voz parece diferente ao ouvido humano, devido a constipações ou a um grande ruído de fundo.

A tecnologia de rede Neural é utilizada para processar dados biométricos gerados por sensores. Por exemplo microfone e processos de codificação. A combinação das características biométricas e dos Smart Cards irão produzir novas tecnologias com significativas melhorias para aplicativos existentes, além de criar novas aplicações com dispositivos de segurança de alto nível.

\begin{tabular}{|l|l|}
\hline \multicolumn{1}{|c|}{ CARTÕES MAGNÈTICOS } & \multicolumn{1}{|c|}{ CARTÕES COM CHIP } \\
\hline $\begin{array}{l}\text { Obtemos informação do cartão apenas } \\
\text { durante o movimento relativo do mesmo } \\
\text { em relação ao leitor ou cabeça deste. }\end{array}$ & $\begin{array}{l}\text { Depois do cartão estar conectado } \\
\text { podemos transferir toda a informação } \\
\text { que quisermos do ou para o cartão. }\end{array}$ \\
\hline $\begin{array}{l}\text { Pequena informação limitada em cada } \\
\text { pista como já foi dito anteriormente. }\end{array}$ & $\begin{array}{l}\text { A quantidade de informação é muito } \\
\text { maior do que em cartões magnéticos. }\end{array}$ \\
\hline $\begin{array}{l}\text { Todas as pessoas, com equipamento } \\
\text { adequado, mas simples, pode ler, copiar e e } \\
\text { duplicar esses mesmos cartões. }\end{array}$ & $\begin{array}{l}\text { Existem vários tipos de cartões no } \\
\text { mercado, cartões esses com capacidade } \\
\text { de memória diferentes e vários graus de } \\
\text { segurança. }\end{array}$ \\
\hline
\end{tabular}

Diferenças entre cartões magnéticos e Smart Cards

Fonte: http://www.abrapinet.org.br 
Os sistemas automáticos de controle de acesso baseados em impressões digitais, permitem um controle de alta confiabilidade através das características imutáveis e únicas de cada impressão digital.

O controle de acessos de portas com o uso de chave eletrônica de decodificação de impressões digitais foi desenvolvido pela "Dallas Semicondutor". Um kit experimental, de funcionamento básico. Este sistema utiliza um PC para gerir o controle de acessos com a ajuda de uma base de dados. A comunicação entre o sistema e o PC é feita através de rede. Sendo de fácil instalação e de baixo custo, permite controlar os acessos a um edifício quando instalado em uma ou em várias portas. O software disponível suporta um controle de acessos para várias portas. O PC opera como hospedeiro e gestor da MicroLan, e lendo da memória, controla e fornece energia a instrumentos através de um "Switch Endereçável" tais como contactores e trincos elétricos.

Hoje em dia, todos os sistemas de segurança podem estar ligados a uma central de vigilância confiável. A um custo relativamente baixo por mês, a central de vigilância reconhece os diferentes códigos do sistema e toma as precauções necessárias.

\section{Monitoração e Controle}

A utilização de fontes de energia alternativas e de equipamentos de conversão de energia de elevado rendimento é uma das vias para um melhor aproveitamento dos recursos disponíveis. A monitoração e o controle destes equipamentos são essenciais para que a sua utilização seja efetuada de um modo eficaz. A aplicação de sistemas de controle e gestão de energia e o desenvolvimento de novas técnicas, dispositivos e algoritmos para aumentar a potencialidade destes sistemas são também um setor de atividade de grande importância.

O desenvolvimento dos próprios equipamentos de utilização de energia, para o setor residencial, deve ser um campo de atividade a merecer estímulo. Interessa também conhecer as características energéticas dos equipamentos mais significativos na utilização final da energia. Existem potencialidades de melhoria de rendimento no funcionamento de um conjunto de dispositivos que podem e devem ser investigados.

Se o usuário quiser, pode programar determinadas tarefas domésticas para aproveitar os benefícios da tarifa noturna, tais como lavanderias, compressores, motores e a ativação de acumuladores de calor para que estejam em carga durante a noite. Estas possibilidades de aproveitamento energético são especialmente interessantes em edifícios ou instalações comerciais e industriais, onde haja um grande nível de atividade durante $\mathrm{o}$ dia e pouca durante a noite. 


\subsection{Outros Sistemas \\ 5.4.1 Transporte Vertical}

O transporte vertical em edifícios obedece aos princípios de Arquimedes ou Pascal. Os elevadores sobem ou descem suspensos por roldanas e contrapesos ou seguindo as leis de multiplicação das forças hidráulicas por pistões e cilindros. No Brasil, os elevadores mais comuns funcionam pela física de Arquimedes. Nos Estados Unidos, antes da eletricidade, existiam elevadores a vapor. Hoje coexistem quatro sistemas de alimentação de energia para estas máquinas: corrente alternada com tensão e freqüência variáveis, corrente contínua e corrente contínua com conversores estáticos.

O sistema movido por corrente alternada com tensão e freqüência variáveis entrou no Brasil depois da abertura de 1991 e mudou o panorama da área de projeto de elevadores. Houve uma redução significativa no número de engrenagens, o que conseqüentemente reduziu o atrito e o nível de ruído além de minimizar o consumo de energia e exigir pouca manutenção. Muitos deles também fazem o autodiagnósticos, permitindo que eventuais defeitos sejam corrigidos antes mesmo de serem percebidos pelos usuários.

Os elevadores podem ser divididos em dois grupos em relação ao tipo de controle dos sistemas: o de controle de lógica, segurança e sinalização que funciona como cérebro do elevador e se encarrega de definir e coordenar a estratégia do elevador; e o de controle de movimento/ acionamento, que determina a dinâmica do elevador e é responsável por acionar a máquina de tração.

Hoje todos os controles de lógica, segurança e sinalização são realizados por microcontroladores de alta performance. Eles são agrupados em um controlador lógico programável dedicado, localizado na casa de máquinas do elevador, que pode formar tanto um sistema centralizado como um sistema modular de Arquitetura distribuída. O sistema fica trabalhando em rede e executando várias funções de lógica como abrir e fechar de portas; subir e descer; determinar em que seqüência deve atender as chamadas; quando deve desabilitar as chamadas; definir em que pavimentos 0 elevador deve parar para desembarque de usuários nas operações de subida ou descida e etc. Esse controlador monitora também todos os sistemas de segurança e sinalização de interface direta com o usuário, verificando se as portas da cabine estão travadas mecânica e eletricamente; checa se a rede de alimentação elétrica está em condições de movimentar o elevador, verifica se a cabine está no nível do pavimento (caso contrário manda nivelar e ainda atualiza os sistemas de sinalização de interface com o usuário, como indicadores de posição, setas direcionais e comunicação via sistema de voz digitalizada). 
Ainda com relação à segurança, no caso do elevador ultrapassar certa velocidade, o sistema de segurança eletromecânico age numa primeira etapa parando-o suavemente e posicionando-o no pavimento mais próximo para que os passageiros possam descer. , Em seguida, o sistema desliga o elevador e trava.

\section{Caso CENU - SP}

O tempo de espera de elevadores e as muitas paradas até que se chegue ao pavimento desejado são algumas das causas de maior irritação de quem freqüenta grandes edifícios. Os empreendedores da Torre Norte acreditam ter resolvido o problema.

Ao todo são 24 elevadores, incluindo cinco hidráulicos que atendem aos subsolos, desenvolvidos pela empresa japonesa Fujitec. Com o objetivo de agilizar e racionalizar a circulação vertical e o fluxo de pessoas, o edifício divide-se em três zonas - baixa, média e alta. Cada uma delas é atendida por seis baterias de elevadores com velocidade de $2,5 \mathrm{~m} / \mathrm{s}$ a $6 \mathrm{~m} / \mathrm{s}$. Um grupo serve os andares situados entre 0 térreo e o $12^{\circ}$ andar. Outro, do $13^{\circ}$ ao $23^{\circ} \mathrm{e}$, finalmente, um terceiro vai do $24^{\circ}$ ao $35^{\circ}$, à velocidade de $6 \mathrm{~m} / \mathrm{s}$. Cinco elevadores independentes ligam os andares

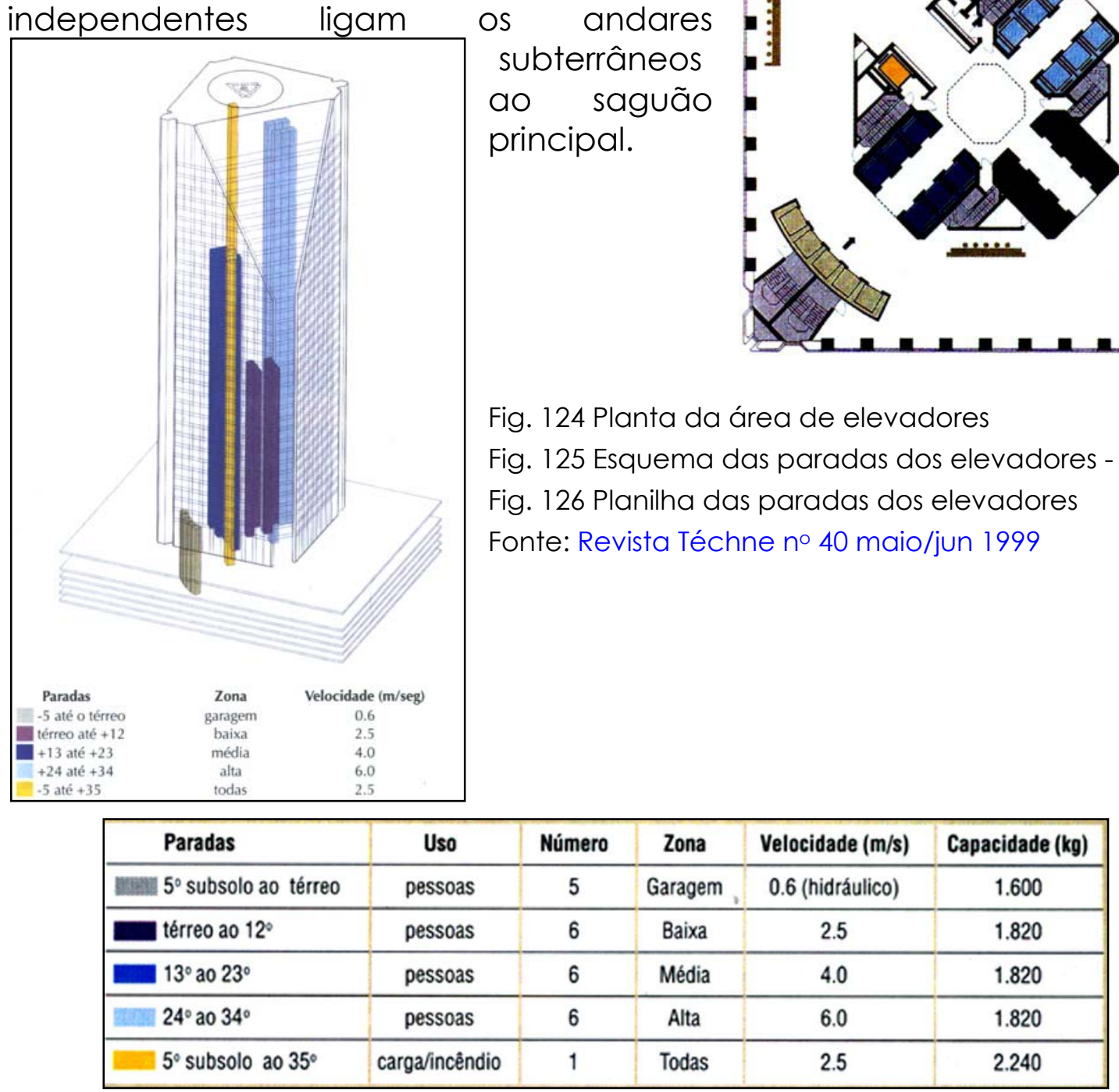




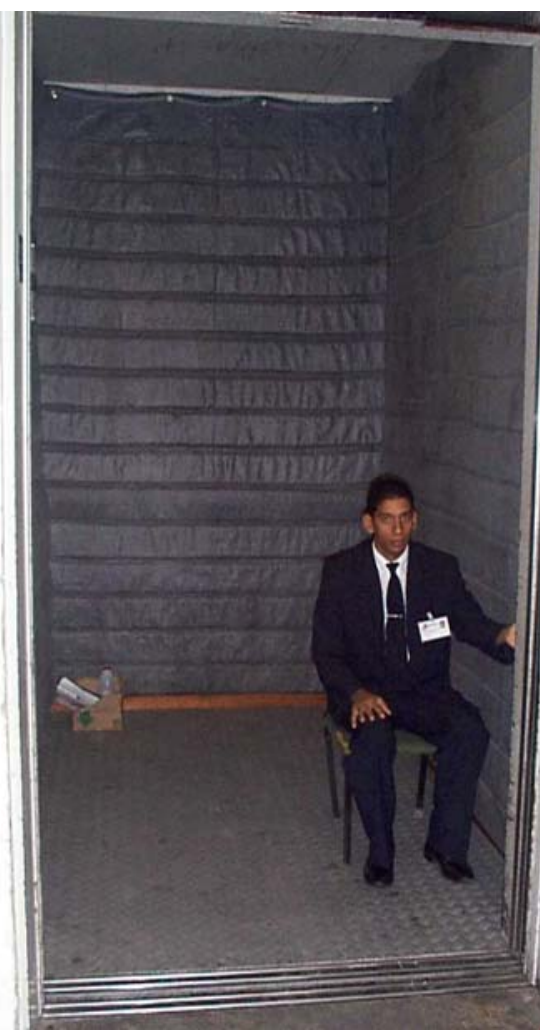

Complementando, um elevador jumbo, que serve a todos os andares, ou seja, do 30 subsolo ao $35^{\circ}$ pavimento, se destina exclusivamente ao transporte de cargas e situações de emergência.

Todo o sistema de circulação vertical interligase ao controle de portaria, impedindo $\mathrm{O}$ acesso de pessoas sem identificação, Os elevadores fazem também a memorização de fluxo e trajeto para

I. Fig. 127 Elevador de Carga

Fig. 128 Sala de controle dos elevadores

fonte: Arquivo Pessoal racionalizar as operações de deslocamento.

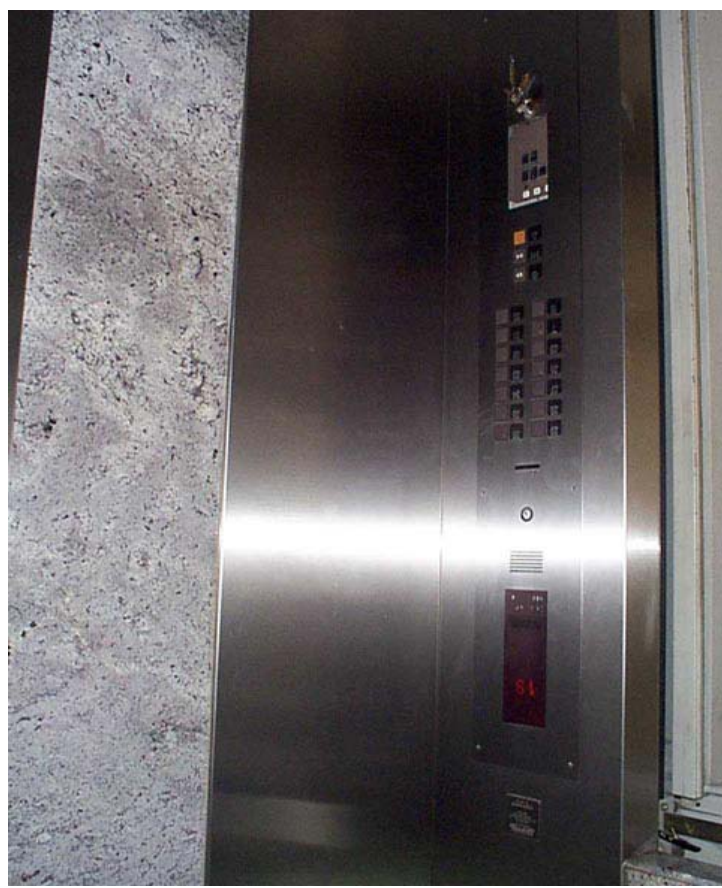

Para acabamento interno das cabines foram utilizados materiais como aço inoxidável e granito, não só pela estética, como também pela facilidade na manutenção e limpeza.

Fig. 129 Interior de um dos elevadores CENU-SP, uso de materiais como granito e aço inox para acabamento.

Fonte: Arquivo Pessoal 


\section{Retrofit}

A busca de economia, a preocupação com a estética e a necessidade de aumentar a velocidade de transporte motivam a modernização de antigos elevadores.

Qualquer elevador pode ter melhor desempenho com uma modernização parcial. Peças com vida útil esgotada podem ser trocadas, pode-se atualizar a tecnologia para tornar o equipamento mais ágil, otimizar o gerenciamento de chamadas, reduzir o consumo energético e remodelar a cabina.

Todas as peças e equipamentos dos elevadores possuem vida útil determinada e necessitam de manutenção periódica. Em geral, quando esse prazo chega ao limite, a peça necessita de reparos ou troca. 0 problema é que essa exigência nem sempre é cumprida, e são lançados recursos para contornar a troca dessas peças. A prática põe em risco as

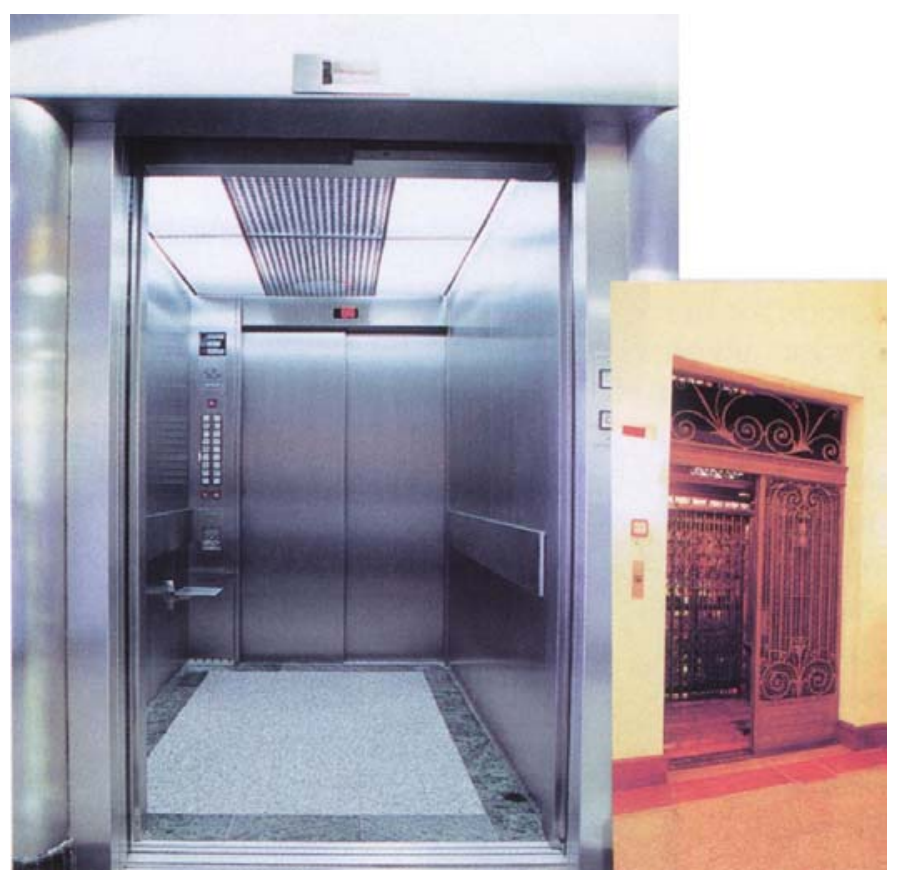

pessoas e compromete 0 desempenho do equipamento. No Brasil, $15 \%$ dos elevadores em uso foram instalados há mais de 35 anos; $40 \%$ têm mais que 15 anos e $20 \%$ são mais recentes, com menos de cinco anos.

Fig. 130 Remodelação da cabine do elevador

Fonte: Revista Téchne no 59 Fev 2002

\section{Modernizar}

Primeiramente é importante planejar financeiramente a modernização de forma que os custos se ajustem ao fluxo de caixa do condomínio e não sejam amortizados de uma única vez. A reforma de um elevador, em geral, é bastante cara.

Depois parte-se para uma análise das necessidades dos usuários. Há empresas que oferecem pacotes de modernização que vão desde um simples redesign da cabina, até mesmo alterações mais complexas, como mudança do sistema de comando.

Alguns dos pontos levados em consideração: 
$\checkmark$ Estética - com o tempo, a cabina do elevador apresenta riscos, descascamentos e manchas, tanto na botoeira quanto nas paredes. $O$ piso pode ficar desgastado e a iluminação e ou a ventilação deficientes.

$\checkmark$ Deficiências mecânicas - em alguns casos as portas apresentam problemas de contato, o elevador forma degraus com os pavimentos, a aceleração e desaceleração são desconfortáveis, a cabina vibra nas viagens e apresenta ruído.

$\checkmark$ Idade dos componentes - em elevadores com mais de 15 anos as peças começam a apresentar desgaste.

$\checkmark$ Atualização tecnológica - prevê a substituição de tecnologias ultrapassadas por atuais.

$\checkmark$ Casa de máquinas - com a modernização, o tamanho da casa pode ser reduzido.

$\checkmark$ Velocidade - está diretamente ligada às dimensões do poço do elevador e da cota da laje que sustenta a casa de máquinas, além do próprio desempenho da máquina.

$\checkmark$ Segurança - item de maior preocupação. O limitador de velocidades e o dispositivo controlador das portas devem ter uma correta manutenção a fim de evitar acidentes fatais.

$\checkmark$ Consumo de energia - com a otimização do quadro de comando é possível reduzir em até $40 \%$ o consumo de energia do sistema.

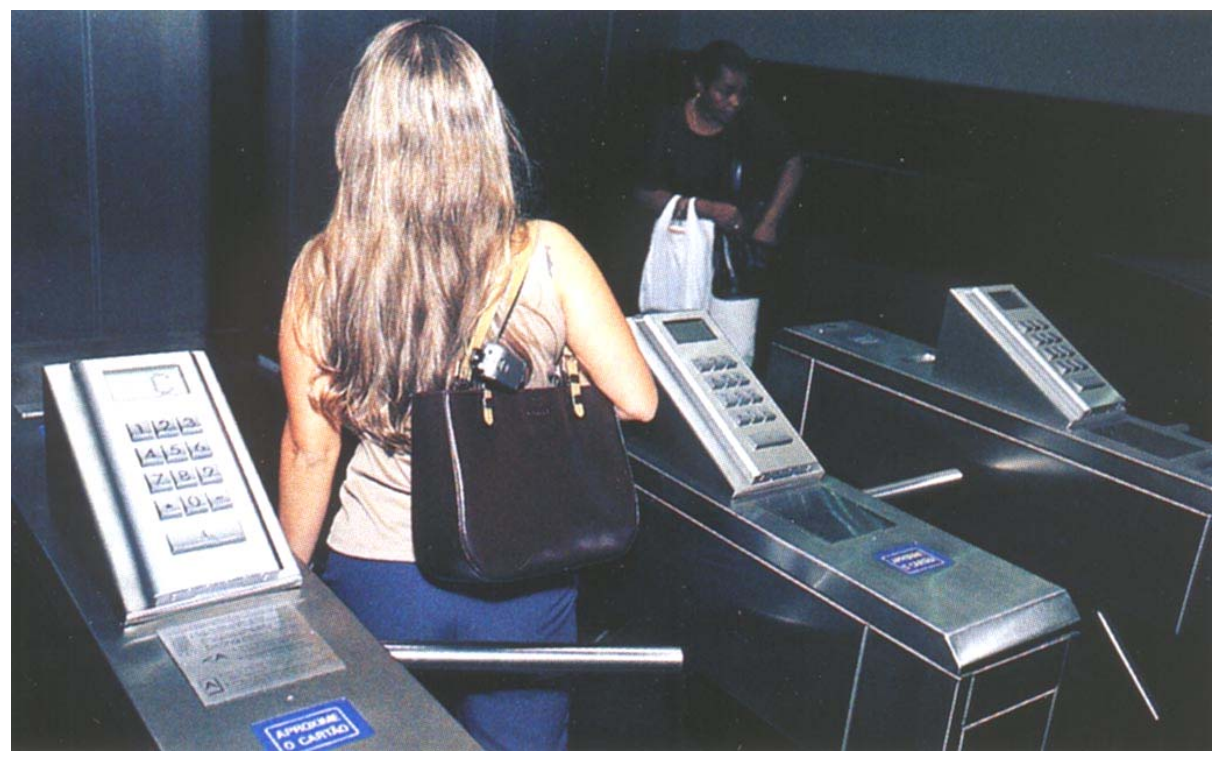

Fig. 131 Sistema de triagem - o usuário escolhe o andar de visita antes de acessar o elevador. De imediato o terminal calcula qual carro está mais preparado para atender a chamada e indica ao usuário o número do elevador disponível, eliminando a botoeira interna e reduzindo o tempo das operações. 


\subsubsection{Conforto Acústico / Sonorização de Ambientes}

Sabe-se que o barulho excessivo em locais de trabalho pode provocar estresse, dores de cabeça, impotência, além de surdez. O que pouca gente sabe é que os ruídos mais perturbadores podem ser gerados dentro dos próprios locais de trabalho.

Em escritórios, o barulho pode ocorrer de forma mais sutil, mas é igualmente perturbador: campainhas de telefone, impressoras de computador, ventiladores, aparelhos de ar condicionado e vozes humanas, que em certas combinações e freqüências podem se tornar insuportáveis.

Os critérios para avaliar o conforto do homem estão sempre relacionados com a tipologia do ruído impactante e a atividade que esteja sendo desempenhada em dado momento. Os níveis limite de pressão sonora são resultados estatísticos de investigações e representam valores admissíveis pela maioria dos indivíduos de diferentes classes sociais. As medições são feitas com o auxílio de aparelhos devidamente aferidos e reconhecidos por órgãos competentes.

Dos anos 80 para cá, o Brasil vem presenciando uma pequena revolução arquitetônica. Os prédios ficaram mais modernos, o uso de iluminação e elevadores inteligentes aumentou, assim como 0 de materiais tecnologicamente mais avançados, como o gesso acartonado.

A tecnologia do tratamento acústico também evoluiu. Hoje temos no mercado materiais muito mais eficientes para proteção acústica do que há 20 ou 30 anos. Entre eles o gesso acartonado, os vidros duplos e os painéis de concreto para fechamento de fachadas. Mas é preciso deixar claro que o tratamento acústico depende apenas em parte da tecnologia. $O$ mais importante é ainda o bom uso dos materiais com relação ao destino do espaço. É importante também trabalhar o som e o silêncio de maneira a não desagradar as pessoas. A acústica, afinal de contas, não é uma área da engenharia ou da Arquitetura, embora se aplique a ambas. É uma área da física.

O tratamento acústico exige um conhecimento específico, pois se trata de uma ciência pouco difundida, mesmo com seu grande alcance. Poucos sabem do que se trata e de como ela está disseminada nas ciências e no cotidiano.

Em 1919 foi fundada a Sociedade Americana de Acústica que é a maior do mundo, uma referência universal. Ela tem catalogado mais de dez áreas de atividades. A Sociedade Brasileira de Acústica, que foi fundada há poucos anos, é uma fração da americana e tem catalogado bem menos áreas. Entretanto, as mais importantes estão presentes no Brasil, são elas:

- Acústica arquitetônica 
- Ultra-som, muito usado na área médica e também na indústria, para descobrir falhas de materiais.

- Infra-som, as vibrações abaixo do som audível e que anunciam os terremotos.

- Outros campos são acústica oceanográfica, bioacústica animal, acústica musical, comunicação, acústica subaquática, engenharia acústica.

O desenvolvimento de pesquisas relacionadas à acústica fica restrito a Europa, Estados Unidos e Japão e quase não é feita no Brasil.

Em relação à Acústica Arquitetônica no Brasil, pode-se notar uma maior preocupação hoje do que há alguns anos. Esta preocupação foi originada devido às mudanças nos conceitos de qualidade de vida e do próprio estilo dos edifícios modernos, que passaram a ser entidades quase autônomas, isoladas do meio ambiente. Para isso, o tratamento acústico é fundamental. Mas a verdade é que, se a preocupação existe, a aplicação é ainda muito pequena. Os empreendedores não investem muito porque se ressentem do gasto extra representado pelo tratamento acústico - que, na verdade, é uma pequena fração do custo de um edifício. A maior parte dos empreendedores contenta-se em colocar forros acústicos ou janelas de vidros acústicos. O projeto, se é que pode ser chamado assim, é executado por alguém da construtora, ou por profissional com noções gerais de acústica. Poucos edifícios comerciais têm de fato tratamento acústico. $O$ tratamento acústico é ainda mais utilizado em salas de espetáculo, por motivos óbvios. Nelas, o tratamento tem de ser realmente de boa qualidade.

Dados estatísticos levantados recentemente, mostram que ainda é pequeno o número de prédios (residenciais e comerciais) tratados do ponto de vista acústico no Brasil. A grande maioria deles concentrados em São Paulo e no Rio de Janeiro. Como referências pioneiras no Brasil podemos citar:

\section{Caso Citibank - SP}

O prédio do Citibank, na avenida Paulista, construído em 1986, é um exemplo. O projeto arquitetônico é de Gianfranco Gasperini e o padrão de excelência acústica é muito alto. O prédio é constituído de escritórios panorâmicos onde foi preciso buscar uma síntese completa entre o conforto acústico e a operação do edifício.

Em um escritório muito silencioso pode-se não ouvir o barulho de fora, mas perde-se a privacidade. Consegue-se escutar uma conversa por telefone a 5 $m$ de distância, por exemplo. Isso foi levado em consideração no prédio do Citibank e o resultado foi excelente.

Foi usado o barulho do ar-condicionado no projeto acústico. Quando é muito silencioso, o ar-condicionado não mascara o som ambiente e quando é muito alto, torna-se irritante. Então, foi feita uma aliança entre o ruído do ar-condicionado e um sistema de mascaramento eletrônico com alto- 
falantes sobre o forro, que imita o barulho de chuva. É muito baixinho, quase imperceptível, mas funde-se com o som do ar-condicionado e mascara as vozes do ambiente.

Foram utilizados também sistemas de isolamento sonoro. Um desses sistemas empregados são biombos de aglomerado de madeira com espuma dos dois lados. O forro de chapas metálicas perfuradas com aplicação de lã de vidro também cumpre esse papel, assim como os vidros especiais das janelas, que impedem a entrada dos ruídos de fora. A colocação desses materiais obedeceu a cálculos rigorosos. Entre as chapas metálicas e o concreto do teto há um espaço de ar com dimensões corretas. O material absorvente sobre as chapas perfuradas tem exatamente $37 \mathrm{~mm}$. (Mawakdiye, 2000)

Outro exemplo de edifício tratado acusticamente é o WTC - SP, onde a rede Meliá tem um extremo cuidado com o projeto acústico dos hotéis porque esses funcionam, hoje, como centros de convenções empresariais. No Meliá Comfort WTC há uma central de som ambiente que atua como sistema de alarme e sinalização do prédio. As salas de convenções (dispostas no mezanino) possuem pontos para ligação de autofalantes, CD, DVD ou vídeo. O som, porém, é enviado dessas salas para a central, onde é amplificado e enviado de volta para o ponto de partida. Existe ainda a opção de remeter o som para todas as áreas comuns do edifício.

\subsection{Principais Funções de Gestão desempenhadas pelos Sistemas e Serviços de Automação Predial}

Este item trata das questões relativas à função e gestão da tecnologia do Edifício Inteligente. Observamos que ela não se confunde com a gestão do Edifício Inteligente enquanto empreendimento comercial, o que trataremos no capítulo 6.

Dentre as mais importantes, destacam-se as de gestão dos sistemas técnicos e dos serviços que fazem o edifício funcionar, o balanço e planejamento da otimização energética do edifício, e por último a questão da gestão da segurança dos sistemas, que embora já tenha sido tratado em parte no item 5.3, aqui ganha um lugar privilegiado.

Salientamos ainda que as questões da gestão devem ter uma interface híbrida, pois, em parte o sistema é automático e em parte ele deve ser monitorado por técnicos e engenheiros permanentemente.

\subsubsection{Gestão dos Sistemas e Serviços}

Os sistemas de automação devem ser capazes de decodificar as mensagens de sensores e exercer sobre atuadores, com ou sem a 
participação dos seres humanos, tomar decisões que organizem o uso e as condições das instalações e dos vários ambientes de um edifício.(Marte, 1995)

Para os Sistemas citados anteriormente, este sistema é capaz de:

1. Monitorar o estado atual dos equipamentos e de outros elementos associados a um determinado Sistema:

- Indicar se o equipamento está ligado/desligado;

- Verificar a posição da chave local/remoto, indicando se o equipamento pode ou não ser remotamente controlado;

- Indicar o desligamento/ligamento de algum equipamento por algum motivo de defeito ou falha deste ou da instalação;

- Indicar a leitura de grandezas analógicas, temperatura, pressão e vazão;

- Leitura da posição atual de um atuador.

2. Posicionar o estado destes equipamentos:

- Ligar/desligar remotamente equipamentos;

- Através do ajuste do set-point, dentro dos seus limites de atuação - faixa de 0 a $100 \%$.

3. Executar algoritmos de controle e/ou otimização específicos por equipamentos e áreas:

- Possibilitar o ligamento/desligamento de equipamentos em horários préprogramados, calendários, eventos exteriores, e resultado de cálculos lógicos ou matemáticos, por exemplo, programação horária;

- Indicar através de arquivos históricos a totalização de horas de funcionamento, horas paradas, ou consumo elétrico ( $\mathrm{kWh}$ ) para os equipamentos a serem monitorados;

- Registrar através de arquivos históricos, grandezas analógicas para os equipamentos ou linhas de energia que se quer monitorar;

- Exercer controle sobre atuadores analógicos em função de entradas analógicas, cálculos matemáticos, eventos, etc;

- Registrar através de arquivos históricos os alarmes ou outras indicações por equipamentos ou por áreas;

- Possibilitar funções lógicas e matemáticas

4. Apresentar as informações provenientes dos processos controlados e/ou supervisionados em quadros sinóticos:

- Possibilitar associar um evento qualquer nos processos ou totalização máxima de operação de um determinado equipamento com um alarme ou um outro indicativo da ocorrência do fato, por exemplo, um diagrama sinótico. 
5. Configurar a Arquitetura do sistema e parâmetros de controle:

- Possibilitar através de interfaces gráficas ou outro tipo de interfaces a configuração de: pontos de controle, parametrizações, elementos de controle e elementos de sistema - por exemplos gateways (conversores de protocolos).

\subsubsection{Gerenciamento da Energia}

Os programas de manutenção podem ser programados diariamente ou semanalmente segundo períodos de manutenção preventiva, tarefas, projetos de trabalho, planos de reparações ou planos de reparações de emergência. O sistema inicializa imediatamente respostas às quebras ou falhas registrando situações de alarme para quaisquer condições fora do normal ocorridas no edifício. Assim lidamos e gerimos com maior eficiência todo o edifício, menos quebras, aumentando o conforto dos utilizadores e diminuindo os consumos energéticos.

Os programas de gestão de energia podem incluir um sistema capaz de técnicas de auto-aprendizagem temporal, ou seja, ele pode ir armazenando dados de ligações de aparelhos tais como climatizadores e iluminação e com o decorrer do tempo criar bases de dados historiais para calcular o tempo possível de inicialização de um determinado sistema e obter um conforto adequado.

Processadores com técnicas de auto-aprendizagem são capazes de prever a hora de funcionamento de um determinado compartimento. Durante um período de não utilização de uma divisão, o sistema deverá ser capaz de alterar a iluminação e climatização para parâmetros definidos como noturnos ou de não funcionamento, como é o caso do ciclo noturno. Durante o período de utilização, o sistema deve ser capaz de conservar energia e otimizar o uso de energia elétrica ligando e desligando o sistema de climatização, encontrando-se sempre dentro de limites pré-definidos de conforto.

Em qualquer Edifício Inteligente deve existir um gerador de energia elétrica de forma a estar sempre presente em qualquer situação de emergência. Esta energia de emergência terá como função o fornecimento de corrente elétrica que garanta os sistemas de segurança mínimos, tais como luzes de emergência, serviços de detecção de incêndio, assim como todo o equipamento ligado ao PC (Master) da gestão do edifício e equipamentos de ar condicionado de áreas pré-determinadas.

Parte da iluminação poderá ser gerida pelo sistema de gestão de energia. A automação da iluminação pode ser feita através de programação de luminosidade com a ajuda de sensores de iluminância, ocupação ou detecção integradas de maneira a fornecer informação às placas microcontroladoras e conseqüentemente ao PC (Master). Desta forma, com 
o controle e automação da iluminação podemos obter diminuição dos consumos energéticos nesta área entre os 30 e $50 \%$.

Os sistemas de controle de iluminação por computador utilizam comunicações em par entrelaçado para ligar o sistema de iluminação a CPU utilizando painéis transdutores (FPUs). Cada planta está dividida em várias zonas. A gestão da iluminação é feita a partir do PC (Master). As luzes acendem-se e apagam-se segundo horários previstos e programáveis, consoante a estação do ano, o tipo de compartimento, a previsão de horas de ocupação, etc. Deve existir uma rede de iluminação manual, ou então ser previsto a comutação do sistema de automático para manual, sempre que seja necessária permanência de alguém no edifício depois do horário previsto. Em modo automático, as luzes acendem-se à entrada de um indivíduo onde a iluminação não é suficiente. As luzes se apagam de forma temporizada quando não detectam presença, sendo esta temporização programada a qualquer momento e independente de compartimento para compartimento.

\subsubsection{Gestão da Segurança dos Sistemas}

Os sistemas de automação predial devem ser capazes de decodificar as mensagens dos sensores de presença, detectores de fumaça ou controladores de acesso, assim como posicionar câmaras de CFTV e acionar elementos indicativos de situações de alarmes, conforme será detalhado, com ou sem a participação de seres humanos.

Possibilidades dos sistemas:

1. Através de controle de acesso e telebloqueio, permitir a entrada de pessoal e determinar a sua rota através dos telebloqueios.

2. Para o sistema de detecção de fogo:

- Indicar o estado dos detectores e das linhas (redes de detectores);

- Indicar o estado das chaves de fluxo de rede de sprinklers;

- Temporizar a ativação de alarmes em função de eventos associados a este sistema;

- Associar eventos com diagramas sinóticos e procedimentos automáticos, que irão disparar ações pré-programadas de combate a incêndio.

3. Através da segurança perimetral interna e externa, associar alarmes e câmeras, para formar um registro histórico visual destes. 


\section{A Gestão Empresarial e os}

Investimentos nos Edifícios Inteligentes 


\subsection{Gestão da Produção}

A produção dos Edifícios Inteligentes exige que as construtoras passem por uma série de alterações nos seus hábitos de relações inter-empresariais, de pessoal, de gerência de recursos, etc. Assim, a construtora do futuro será uma empresa de multifunções, atuará como integradora de negócios e de conhecimentos capaz de desempenhar e agregar diversas atividades. Atuarão no campo de incorporação e desenvolvimento de negócios, gestão de contratos e administração e manutenção de empreendimentos. Será empreendedora de negócios ou gestora de negócios de terceiros. Para chegar lá, as construtoras de hoje precisarão aperfeiçoar a capacitação financeira e a gestão administrativa e executiva da empresa. Este rumo já está sendo tomado por construtoras como Hochtief, Método, Setin, Inpar e Gafisa.

De acordo com o consultor Nilton Vargas, a mudança de postura dessas empresas deve-se a um acirramento da competitividade. "De uns anos para cá, a concorrência no setor ficou ainda maior. As tecnologias foram, de certa forma, democratizadas para grandes e médias construtoras. Ficou evidente a necessidade de um diferencial de mercado", analisa Vargas. Os primeiros passos dessa trajetória começaram a ser dados há alguns anos com o avanço da terceirização sobre as atividades do canteiro e o conseqüente enxugamento dos quadros operacionais. A Método Engenharia, por exemplo, de quatro mil funcionários passou para 400, mesmo caminho trilhado pela Gafisa.

Esse processo foi acompanhado por um aperfeiçoamento nos sistemas de gestão, tecnologia e qualidade. Ou seja, na "inteligência" das empresas. A Método, por exemplo, vem desenvolvendo um sistema de parceria fixa com seus fornecedores e prestadores de serviço que é a base de sua estrutura atual. Essa formatação passa por um sistema de seleção e fiscalização rígidos, a fim de garantir a manutenção da qualidade dentro dos padrões exigidos. No caso da Método, os diretores fazem questão de afirmar que não se trata de uma metodologia simplesmente, mas de um sistema baseado em um código de princípios. "Nosso sistema está fundamentado na confiança mútua e em uma relação confiável entre a empresa e seus fornecedores", afirma Hugo Marques da Rosa. Na prática, a empresa trabalha com fornecedores fixos e evita o desgaste de lançar-se em concorrências ou excesso de fiscalizações.

Neste ano, a empresa deverá investir mais tempo no treinamento do seu quadro técnico sob um enfoque mais humanista, conforme revela Roberto Tadeu Mingrone, gerente de desenvolvimento organizacional da Método. "O engenheiro no Brasil não é preparado para lidar com pessoas ou coordenar grupos. E esta é a função que ele acaba realizando como engenheiro de produção", diz Hugo Marques da Rosa, presidente do conselho de administração da Método. Para ele, esta é uma lacuna atualmente mais relevante do que a questão do analfabetismo na 
construção civil. A seu ver, os novos tempos pedem uma postura diferenciada dos engenheiros, mais receptiva ao aprendizado, para que permita o fluxo do conhecimento entre todos os elos da cadeia, do mestrede-obras aos projetistas. "Nossa estratégia é oferecer produtos de maior qualidade e valor agregado", afirma Marques da Rosa. Ele explica que a meta exige treinamentos e investimentos, mas também "passa pela organização da empresa, novos relacionamentos com os parceiros e uma gestão do conhecimento visando uma rede de competências integradas".

Para o consultor Nilton Vargas, um novo modelo de relações pessoais e de negócios deverá ser a base do upgrade das empresas do setor nesta década. "A construção é o setor mais atrasado em termos de gestão empresarial com relação a outros segmentos produtivos", diz Vargas. Segundo ele, as empresas modernas estão percebendo o valor do knowhow do conhecimento que é acumulado por seus funcionários, mas que em geral se perde ou fica dissipado entre as diversas áreas da empresa. É comum, por exemplo, em uma mesma empresa, duas equipes se empenharem para solucionar problemas similares. "O conhecimento é da empresa, mas está no funcionário. É preciso criar técnicas para registrar e documentar esse aprendizado, que pode acelerar e aperfeiçoar os projetos futuros", diz Nilton Vargas.

Giorgio Vanossi, diretor de engenharia da Setin (empresa voltada para a introdução de novas tecnologias), compartilha da mesma opinião. "Na construção tem muito disso. Cada obra é uma nova história". Segundo Vanossi é possível pegar atalhos e diminuir o custo do retrabalho do raciocínio, que se evidencia em projetos mais ajustados e definidos. No caso da Setin, esse processo tem fundamento na inserção cada vez maior da informatização nos processos de gestão, na visão da construtora como uma empresa de montagem e gerenciamento. "Haverá uma divisão natural no mercado, com empresas especializadas na execução de serviços, de um lado e construtoras dedicadas a coordenar todo o processo construtivo e de desenvolvimento do negócio de outro."

Acostumadas à atividade de construir, o desafio para essas empresas passou a ser o de mudar de perfil sem perder suas características originais. Por isso, uma preocupação comum a elas é a qualidade do fluxo de informação e do processo de acúmulo de conhecimento - ao deixar de executar diretamente os serviços, o sigilo industrial de cada empresa passou a se concentrar em seu know-how técnico e empresarial. Para o consultor Nilton Vargas, essa busca acabou se direcionando a um modelo de gestão caracterizado por redução da hierarquia, em que a informação flui com maior facilidade e que requer maior democratização das relações de trabalho, com compartilhamento das responsabilidades e descentralização do poder.

Parte de uma holding internacional, a construtora Hochtief desencadeou o seu processo nesse sentido há cerca de cinco anos. O diretor presidente André Glogowsky explica que os níveis hierárquicos na empresa foram reduzidos ao máximo e resumiram-se à presidência, diretoria e gerentes de 
contrato. "Estes são os responsáveis por levar as informações aos outros setores". Cada empreendimento a ser desenvolvido gera um fórum técnico e comercial (project team), formado por gerentes e funcionários de todos os setores envolvidos na execução. Os participantes contribuem com o seu expertise para aperfeiçoar o orçamento e o planejamento da obra. "Temos plena consciência que o nosso corpo técnico é essencial para o aperfeiçoamento do nosso trabalho", diz Glogowsky.

Uma das primeiras a terceirizar atividades, a Hochtief, no entanto, define seu modelo de atuação de acordo com as características de cada contrato. 0 perfil da empresa pode variar de gestora do contrato, executante dos serviços, desenvolvedora de negócios ou co-parceira do empreendimento. "Hoje, é fundamental a empresa ter flexibilidade para se adequar aos diferentes tipos de solicitações dos clientes e do mercado", diz o presidente. Uma das metas da Hochtief é repassar a terceiros também atividades administrativas que não sejam diretamente ligadas ao negócio de engenharia. "Nosso foco é a gestão da engenharia", diz ele, "e o fundamental são os setores de planejamento e orçamento". Sintonizado com as tendências mundiais, Glogowsky diz que a globalização pede relações comerciais mais diretas e confiáveis. "As construtoras devem se posicionar como o agente que vai responder pelo empreendimento todo junto ao cliente, pois é isso que ele quer. Não interessa a esse cliente saber quem vai fazer o quê, mas receber da construtora a garantia necessária para o resultado do empreendimento."

A comunicação é o elo fundamental desse perfil de empresa moderna e ocorre ao mesmo tempo em que se ampliam os recursos produzidos pelas novas ferramentas de comunicação, como as redes de intranet e extranet. A popularização da Web reduziu distâncias, substituiu a hora do cafezinho e transformou o bate-papo virtual numa das marcas desse início de século. Por que não aproveitar isso para melhorar os resultados da empresa? Isso traria benefícios, mas a inserção dessa mania para o ambiente de trabalho com fins absolutamente profissionais pode não ser um passo tão fácil assim.

Um dos grupos que se antecipou na modernização do seu sistema de comunicação interna é o da construtora Norberto Odebrecht. "Desde a década de 90 percebemos a necessidade de reutilizar o conhecimento do nosso pessoal, iniciando um movimento para organizar as informações sobre idéias, métodos e práticas inovadoras disponíveis na empresa", diz Olindina Dominguez, responsável pelo Centro de Informações e Apoio ao Desenvolvimento de Negócios. Logo de início, a Odebrecht adotou um sistema de comunicação baseado nos protocolos da internet, que se transformaria mais tarde numa rede de intranet e virou atualmente um portal corporativo. Nele, ficam disponibilizadas informações aplicáveis a todo o ciclo do negócio.

"Mas a informação é um bem pessoal que o ser humano retransmite se quiser", diz Nilton Vargas. "Colocar um computador na frente de uma pessoa não garante o bom fluxo das informações", adverte. De fato, logo a CNO se depararia com um dos principais problemas desse enredo: a resistência do 
público interno em empregar a ferramenta. "A nossa intranet, como deve ter ocorrido na maioria das empresas, começou como um grande repositório de dados. Embora rica em conteúdo, era pouco utilizada pelo nosso pessoal dos canteiros que continuava reinventando a roda", lembra Olindina.

Mas a empresa não desistiu. Alicerçada em um tipo de gestão descentralizada, em que cada contrato é quase uma nova empresa, o grupo foi atrás de soluções para vencer as resistências encontradas. Criou o "Prêmio Destaque" como estratégia inicial para estimular a documentação e multiplicação das boas idéias surgidas nos canteiros e acabou desenvolvendo um sistema próprio para estimular a transmissão do conhecimento dentro da própria empresa. "O futuro exige a utilização cada vez mais intensa de ferramentas que possibilitem o trabalho cooperativo e integrado à distância", diz Olindina. Entre as metas do grupo, traçadas até 2010, inclui-se o incremento do e-business, um portal com foco em compras e logística.

Para Raul Leite Luna, presidente do conselho de administração da Gafisa, as construtoras brasileiras devem se preparar para um período em que a profissionalização será o maior diferencial de mercado. Isso representa, a mudança de perfil de empresa familiar para uma empresa formada por acionistas. Segundo ele, a própria Gafisa - uma empresa de sociedade anônima - se prepara para abrir seu capital nas bolsas daqui a dois anos. "Esta será uma das mais atrativas formas de captação de recursos", diz ele, "mas exige estruturas empresariais transparentes". Diz ainda que o consumidor brasileiro vem se tornando mais exigente e que as empresas devem procurar atender às novas necessidades do seu público. No caso da Gafisa, que atua basicamente na área residencial, a estratégia passa pelo incremento da comunicação com o cliente via internet. "Dentro do mundo globalizado, a informação instantânea será uma das chaves dos negócios".

Com um perfil receptivo às novas tecnologias, a construtora Setin (especializada na utilização de sistemas industrializados em todo o processo construtivo), buscou a melhoria dos processos de comunicação como um novo desafio competitivo. Entre os passos dados pela empresa, inclui-se a adoção de sistemas de gerenciamento eletrônico dos projetos e das áreas administrativas, que deverá facilitar o perfil de construtora empreendedora de negócios. "O futuro aponta para uma especialização das construtoras nas áreas de negócios", diz Antonio Setin, presidente.

Em seus canteiros de obra, a Setin costuma instalar de 14 a 17 microcomputadores sempre novos. "A obra precisa de tecnologia e agilidade. Depois de dois anos esses equipamentos estão obsoletos e é praticamente impossível reutilizá-los", diz o diretor. Para o processo ter êxito, no entanto, é imprescindível uma disposição dos líderes da empresa, que empurram as demais áreas a se adequar aos novos tempos, nem que seja proibindo o uso de outras alternativas. "O desafio principal é fazer com que os usuários possam selecionar as informações mais relevantes, evitando a perda de tempo com dados inúteis", diz Vanossi. 
Uma nova etapa a ser tocada pela empresa é o aperfeiçoamento dos sistemas de logística do canteiro, dado o avanço da industrialização das etapas e, por conseqüência, da presença de terceiros no canteiro de obra. Hoje a construtora utiliza fachadas prontas, lajes e banheiros pré-fabricados, estruturas metálicas e gesso acartonado. "Para melhorar a sintonia entre as diversas peças do jogo, diz Vanossi, é preciso ampliar os gastos com projeto, que em geral ficam na casa de $5 \%$ do custo total do empreendimento, para um limite de 10\%". O engenheiro destaca ainda a tendência de fornecedores de produtos tornarem-se fornecedores de serviços no canteiro. Segundo ele, esse é um processo irreversível e bastante vantajoso, uma vez que o fornecedor detém maior conhecimento sobre o seu produto e pode agregar maior qualidade ao sistema.

Para Luis Henrique Ceotto, diretor de engenharia da Inpar, a modernização do processo construtivo ainda não terminou e há muito que avançar. "O que deverá ser utilizado nos próximos dez anos ainda não foi concebido", diz ele. A seu ver, a construção deverá sair definitivamente da visão de componentes para uma visão de sistemas construtivos. "À construtora caberá a coordenação da montagem". Para tanto, o Brasil deve avançar no processo de coordenação modular dos produtos. Na sua opinião, essa falta de visão sistêmica e os usos de processos artesanais são as razões da baixa produtividade em uma obra. Essa nova relação deverá ser marcada por um novo tipo de participação dos fornecedores, que passam a agregar mais valor ao seu produto. Segundo Ceotto, o uso dos sistemas industrializados reduziu a necessidade de mão-de-obra na Inpar que era de 45 a 60 homens/hora por $\mathrm{m}^{2}$, para cerca de 15 a 22 homens/hora por m².

Mas, para se adiantar nesse modelo, é fundamental uma preocupação com o sistema de qualidade. No caso da Inpar, foi criado um comitê responsável pelo estudo e avaliação dos procedimentos, que se encarrega da normatização interna. Esse comitê analisa o trabalho dos dez grupos de desenvolvimento de tecnologia e é formado por quatro engenheiros e um consultor externo. Os grupos abrangem os seguintes itens: estruturas, fundações, instalações prediais, segurança, canteiro de obras, vedações (fachadas e portas), impermeabilização, projetos, sistemas prediais e informatização. Uma vez analisadas, testadas e aprovadas, essas normas vão para uma espécie de manual e devem ser seguidas integralmente na obra. Segundo Ceotto, é comum esse trabalho ser requisitado por comitês da ABNT. "São vetores responsáveis pela modernização constante dos sistemas construtivos aplicados dentro do canteiro". O engenheiro diz que esse processo caminha em paralelo com a modernização dos demais processos da empresa, tais como sistemas de contabilidade on-line e sistema de gerenciamento das obras. Ceotto destaca a tendência das construtoras de reduzirem o volume de financiamento, buscando parcerias nos negócios. "Cada vez mais os empreendimentos devem ser vistos como empresas separadas do corpo da construtora. Para isso, as empresas devem ampliar sua visão de negócio focando não somente a tecnologia, mas também a gestão e o gerenciamento do processo". 
Para Fábio Martins, diretor técnico da construtora Conceito, a separação entre execução e coordenação apresenta alguns riscos. "A vocação de uma construtora é praticar a engenharia", diz ele. A seu ver, a atuação em campo é o que permite o acúmulo de conhecimentos que são reaproveitados a cada novo projeto. "A única maneira de ser mais competitivo é investir na engenharia na fase de desenvolvimento do projeto e planejamento", contrapõe. Hoje a Conceito tem como filosofia o desenvolvimento do projeto por um prazo de no mínimo seis meses. "Ainda não é o ideal, mas evoluímos bastante", diz Martins, referindo-se ao processo norte-americano. "Por lá, um empreendimento normalmente é planejado e estruturado durante cerca de um ano, para depois ser rapidamente construído", pondera ele. Para Martins, a terceirização por pacotes de serviço, como tem ocorrido, tem outros inconvenientes. "No caso da engenharia, onde se trabalha com riscos e segurança, é preciso pensar se esse processo é mais eficiente". Ele levanta a questão sobre o BDI em cascata, uma vez que há várias subcontratações, o que em tese pode gerar custos extras. Fábio aponta ainda a necessidade de maior investimento das empresas em gestão, fiscalização e controles, em detrimento ao desenvolvimento das soluções de engenharia.

A Odebrecht montou seu banco de informações via internet, no entanto não funcionou. O trabalho de diagnóstico da Neolabor concluiria que os usuários não se mobilizavam a utilizar a tecnologia. "O foco do processo privilegiava o meio, a tecnologia, e não as pessoas, justamente quem dominava o conhecimento", diz Nilton Vargas. Por isso, as pessoas não se sentiam motivadas a trocar o seu conhecimento. "Para a informação fluir melhor, era preciso aproximar as pessoas", diz. A solução foi sair do meio virtual e criar um ambiente real para que as pessoas pudessem trocar idéias. Assim surgiram, no ano 2000, as Comunidades (redes de conhecimento, caracterizadas por grupos que se reúnem motivados por interesses comuns). Uma das particularidades do trabalho, lembra Vargas, foi levantar qual seria - tema capaz de motivar a participação espontânea dos funcionários. Foram estabelecidos dois grupos principais: aqueles ligados ao tipo de obrabarragens, aeroportos, rodovias - e outro ligado a temas mais abrangentes como qualidade, meio ambiente e segurança.

A criação de uma Comunidade inicia-se com um evento de instalação e inclui dinâmicas de grupo, com o objetivo de estimular os participantes a expor seus conhecimentos sobre o assunto. A partir daí se dá um amplo processo que inclui conversas, consultas, fórum de dúvidas e apresentação de soluções. Os próprios ativistas elegem um líder e decidem o que pode ser disponibilizado na rede. O processo é contínuo e os participantes se tornam ao mesmo tempo uma espécie de consultores internos da empresa, podendo ser chamados a contribuir com seu conhecimento em outros empreendimentos do grupo. A primeira comunidade instalada foi a de Barragens e Usinas Hidrelétricas. Criou-se também o SOS Engenharia e há ainda os grupos de colaboração on-line, que opinam e verificam projetos publicados na rede interna. Por outro lado, esse processo migrou diretamente para a internet, alimentando 0 portal corporativo da 
Odebrecht, que permite uma série de recursos e buscas refinadas. Um exemplo: quando um gerente de engenharia pesquisa alguma metodologia executiva, pode acessar informações de obras similares, currículos de colaboradores que dominam o assunto, lista de consultores internos e índices de produtividade e de equipamentos empregados naquele tipo de serviço. "A idéia é reunir todo esse acervo de informações no meio eletrônico facilitando ao máximo sua utilização por parte dos usuários", conclui Olindina.

\subsection{Gestão Administrativa Predial}

A complexidade de todos os aspectos relacionados em assegurar um bom funcionamento dos edifícios deu origem ao aparecimento de uma nova categoria profissional: os Gestores de Edifícios (Facility Managers).

A Gestão Integrada de Edifícios (Facility Management) teve as suas origens na área da manutenção de edifícios. No entanto, à medida que os edifícios tornaram-se entidades mais sofisticadas e complexas, e em constante mutação, o número de tarefas e aspectos a levar em conta aumentaram significativamente, passando a manutenção a ser apenas um deles.

Refletindo a implantação desta nova classe de trabalhadores, existem por todo o mundo inúmeras associações de caráter profissional que congregam os ditos Gestores de Edifícios, ou quem efetivamente desempenha esse tipo de funções ou ainda quem está associado a elas de algum modo. Essas associações possuem particular relevância nos EUA, no Japão e na Europa (onde se destacam a Inglaterra, a Alemanha, a Holanda e a França).

Nos EUA, a International Facility Management Association (IFMA) foi criada em Outubro de 1980 e congrega hoje mais de 14000 pessoas. No entanto, convém notar que em muitos países, essa categoria profissional não está identificada, nem possui associações que a representem.

Por outro lado, não existem formas "Facility Management". A tradução apresentada torna, por um lado, mais explícita a noção de que existem múltiplas vertentes de atuação e, por outro lado, mostra que todas essas vertentes necessitam ser coordenadas entre si (oficiais ou não) de adquirir conhecimentos e qualificações nesta área.

Em contraste, na Inglaterra é hoje possível obter graus de licenciado, mestrado e até doutorado em Gestão de Edifícios, e é muito diversificada a oferta de cursos de curta duração sobre diversos temas específicos relacionados ao assunto.

O gestor de edifícios tem a seu cargo um conjunto de atividades que dão suporte e potenciam a atividade produtiva das organizações, de forma que estas utilizem a melhor maneira os recursos disponíveis e que possuam a melhor produtividade e competitividade possíveis. 
As áreas de conhecimento envolvidas são a gestão, a administração, as ciências sociais, a Arquitetura e várias vertentes de engenharia (mecânica eletrotécnica e informática).

Dentre as funções que normalmente lhe competem, citam-se as seguintes:

$\checkmark$ Previsão financeira e orçamentação associada às instalações;

$\checkmark$ Planejamento da manutenção de longo e curto prazo;

$\checkmark$ Gestão e distribuição de espaço;

$\checkmark$ Planejamento das instalações e locais de trabalho e ainda a antevisão de novas necessidades;

$\checkmark$ Planejamento e evolução do posto de trabalho;

$\checkmark$ Seleção de equipamento de escritório e mobiliário;

$\checkmark$ Planejamento e gestão de mudanças;

$\checkmark$ Gestão de contratos (aluguéis, arrendamentos, seguros, manutenção de equipamento, subcontratação, etc.);

$\checkmark$ Gestão de reclamações;

$\checkmark$ Gestão do parque imóvel da organização (incluindo os processos de venda, aquisição ou construção de novos imóveis);

$\checkmark$ Gestão de projetos de construção;

$\checkmark$ Planejamento e gestão de operações de renovação;

$\checkmark$ Supervisão de serviços associados às instalações técnicas, à segurança, às telecomunicações, à comunicação de dados, à gestão de cablagem, etc;

$\checkmark$ Supervisão de serviços administrativos gerais (serviços de alimentação);

$\checkmark$ Limpeza, reprografia, transportes, etc;

$\checkmark$ Planejamento de ações e sua coordenação em situações de emergência ou catástrofe (Disaster Planning and Recovery);

$\checkmark$ Registro de toda a informação relevante para permitir a análise da gestão dos edifícios da organização ao longo da sua evolução e comparação com outras organizações similares;

$\checkmark$ Controle das aplicações de normas legislativas no âmbito do edifício (sinalização, proteção contra fogo, qualidade do ar, regras para evitar acidentes no trabalho, aspectos ecológicos, políticas de reciclagem, etc.); 
$\checkmark$ Coordenação de aspectos de educação e formação contínuas.

Ainda cabe uma referência particular à evolução explosiva de produtos informáticos, que visam apoiar o gestor de edifícios nas suas tarefas.

Após uma fase um pouco incipiente e frustrante em que os produtos disponíveis não eram mais que simples adaptações de sistemas genéricos de CAD (Computer Aided Design) e/ou de bases de dados, assiste-se hoje à disponibilização de produtos ditos de CAFM (Computer Aided Facility Management) ou CIFM (Computer Integrated Facility Management), muito completos e eficazes.

A título ilustrativo, existem hoje produtos em que facilmente se pode visualizar o aspecto exterior do edifício, selecionar um piso, visualizar a sua planta, selecionar uma dada área, saber qual a sua dimensão, quem a usa, que fichas de telecomunicações e de comunicação de dados dispõem, a que equipamentos estão ligados, etc.

São também possíveis funcionalidades, tais como simular novas distribuições de espaço, novos cenários de arrumação do mobiliário e gerar listas de ações a realizar para se tornar efetiva a mudança ensaiada. NUNES (1995)

\section{No Brasil}

A função de building manager, também chamada de administrador predial ou gerente de condomínios é relativamente nova no mercado brasileiro. Surgiu na metade da década de 90 graças ao "boom" dos Edifícios Inteligentes, localizados principalmente nas regiões das avenidas Paulista, Faria Lima e Luiz Carlos Berrini.

Os proprietários (basicamente fundos de pensão, construtoras e grandes companhias) descobriram na hora de contratar as pessoas para 0 gerenciamento desses edifícios que o bom e velho zelador não daria conta do recado. Era preciso partir para uma administração profissional.

Havia, no entanto, um problema: não existia ninguém pronto para encarar esse desafio. Quem mais se aproximava do perfil eram os administradores de shopping centers, mas não preenchiam todos os pré-requisitos.

A saída foi buscar executivos que pudessem se adaptar mais facilmente à função. Ainda assim, não era uma tarefa fácil.

Hoje, a carreira de building manager está ficando mais conhecida, ainda mais pelos salários que variam entre 5 e 25 mil reais.

\section{Caso - WTC -SP}

Quem passa pela Marginal do Rio Pinheiros e observa o complexo do World Trade Center, no Brooklin, geralmente não tem idéia do que está por trás da sua portentosa fachada. Composto pelo Shopping D\&D, o luxuoso Hotel 
Meliá e uma torre de 29 andares ocupados por grandes organizações, o WTC é um modelo de modernidade.

Tudo ali funciona com a precisão de um relógio suíço para atender um público diário de 8000 pessoas. Seu "prefeito" é o executivo Helmut José Fladt, um engenheiro agrônomo de 36 anos que tem sob seu comando uma equipe de 180 pessoas, entre subordinados diretos e profissionais de empresas terceirizadas.

Fladt, que fala fluentemente inglês e alemão, trabalhou apenas cinco anos como agrônomo e depois ingressou no setor imobiliário. Aprendeu os segredos das atividades de avaliação e locação de imóveis, que hoje são fundamentais no seu dia-a-dia. Depois de ingressar na Jones Lang La Salle, recebeu, no início do ano passado, o convite para ser o building manager do WTC.

Quando um banco constrói, por exemplo, um prédio para abrigar seus escritórios, o objetivo é fazer o imóvel operar com o maior conforto possível e - menor custo. Já empreendimentos como o World Trade Center, que pertence a 33 fundos de pensão, são construídos com outra finalidade: dar lucro aos seus proprietários. Esse é o principal desafio de Helmut Fladt à frente do WTC. Além de cuidar de toda a manutenção do complexo, ele é o responsável pela consolidação das contas no final de cada mês, pelo investimento dos recursos e até pela representação dos donos na hora da locação de salas e andares vagos. Tem, como qualquer outro executivo, compromissos de rentabilidade e metas para serem atingidas.

Para dar conta do recado, ele precisa, entre outras coisas, conhecer a legislação que rege o mercado imobiliário e como funcionam os sistemas de ar condicionado e de telecomunicações (será dele, por exemplo, a responsabilidade caso ocorra algum problema de comunicação durante uma teleconferência).

A lista de tarefas inclui ainda traçar estratégias de segurança para seminários e convenções, avaliar os custos condominiais, desenvolver treinamentos para seu pessoal e falar tanto a língua dos donos do negócio como a dos porteiros e faxineiros. 


\subsection{Investimentos em Edifícios Inteligentes}

O fundo imobiliário brasileiro foi oficialmente criado em meados de 1993, pela Lei 8.668, e regulamentado pela CVM no início de 1994. Inicialmente utilizado para a viabilização de sociedade em grandes negócios como Shoppings e Empreendimentos Comerciais, os fundos eram constituídos principalmente por grandes empresas patrimoniais e fundos de pensão. A partir de 1999, seguindo o modelo norte-americano, os fundos passaram a ser oferecidos através de cotas de varejo lastreadas em empreendimentos de altíssimo padrão.

Três exemplos de sucesso são, respectivamente, o Fundo Shopping Pátio Higienópolis. Primeiro fundo imobiliário comercializado no varejo, o JK Financial Center lançado no $2^{\circ}$ semestre de 1999 pela Brazil Realty/Cyrela e o Continental Square Faria Lima, lançado no início de 2001 pela Impar.

Os dois primeiros, totalmente vendidos, apesar de serem produtos distintos, apresentam sucesso de desempenho. O JK Financial Center é formado por três lajes de um edifício Triple A, pronto e funcionando, localizado na esquina da Av. Juscelino Kubitscheck com R. Bandeira Paulista. Atualmente, encontra-se no mercado secundário com cotas valorizadas para revenda.

Já o Fundo Shopping Pátio Higienópolis apresenta-se hoje como uns dos melhores e mais rentáveis investimentos imobiliários de São Paulo.

O Continental Square já apresenta $100 \%$ de sua primeira emissão comercializada. Trata-se de um fundo lastreado em cotas através de lajes de um edifício Triple A e unidades hoteleiras de um hotel 5 estrelas.

Desta forma, os proprietários destas cotas passam a participar dos rendimentos da locação de tais empreendimentos. Todo este processo é devidamente regulamentado e auditado por organismos oficiais.

Com isso, os investidores brasileiros passam a contar também com a oportunidade de participar de um grande negócio com excelente perspectiva de liquidez e rentabilidade.

O mercado de edifícios "Triple A" começou a ser desenvolvido no início da década de 90 , com os primeiros produtos voltados para a instalação de sedes de grandes empresas, como Citibank e Banco Safra, já que estas não encontram prédios com infra-estrutura tecnológica que atendesse às suas necessidades.

O mercado de edifícios "Triple A" vem aumentando nos últimos anos, pois o perfil do mercado começou a mudar com a chegada de empresas multinacionais, que necessitavam de áreas maiores e os mesmos padrões sofisticados dos mercados europeus e norte-americanos. Esse padrão de prédio vem sendo desenvolvido principalmente em regiões nobres que 
possuem áreas incorporáveis, como a Berrini e a Marginal, que juntas representam mais de $60 \%$ do mercado de edifícios "Triple A" na cidade.

O gráfico a seguir mostra a evolução do estoque desse padrão e o da cidade de São Paulo.

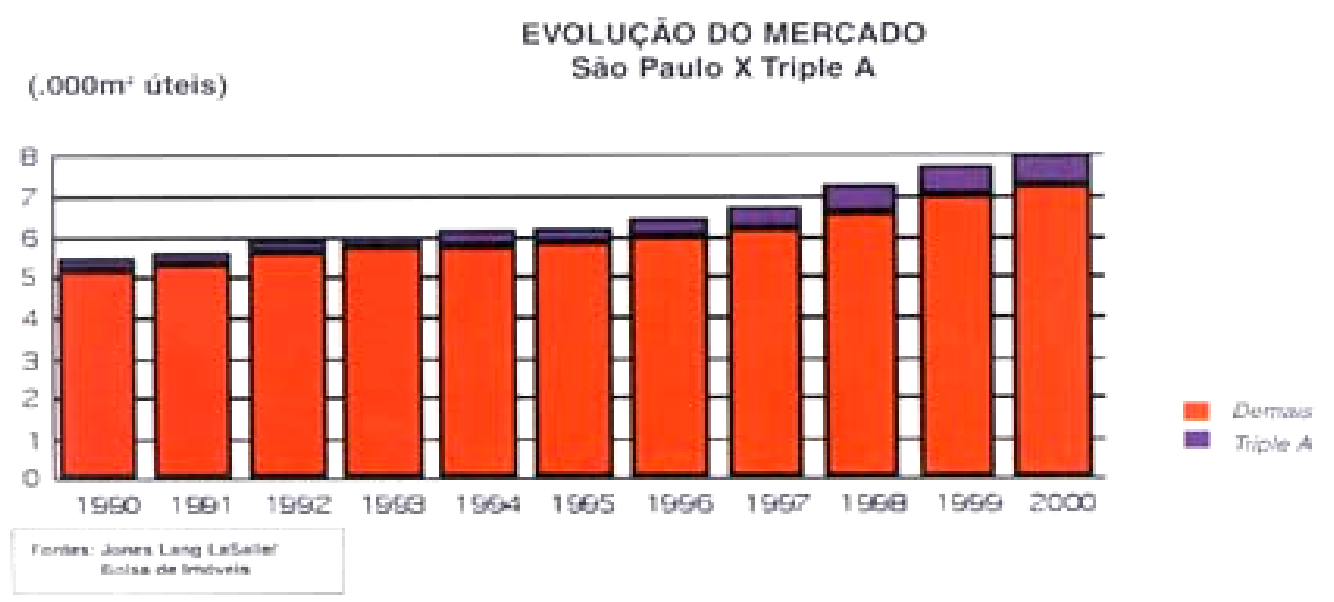

Gráfico 1- Evolução do estoque padrão AAA e o da cidade de São Paulo.

Fonte: http://www.torrenorte.com.br/mercado.htm

A participação de edifícios "Triple A" no novo estoque entregue vem aumentando gradativamente nos últimos anos, representando em média $25 \%$ do total. Mesmo com o aumento desse produto no mercado, a procura por espaços de qualidade e grandes lajes se intensifica a cada ano, pois a oferta continua escassa, principalmente em regiões nobres, o que aumenta a demanda do produto em regiões secundárias.

Além disso, a demanda por edifícios "Triple A" vem aumentando a cada ano e, em 2000, a absorção líquida foi o equivalente ao volume dos 3 anos anteriores, cerca de $150.000 \mathrm{~m}^{2}$ úteis, o que representa $28 \%$ do estoque total.

O ano de 2000 foi marcante para o mercado de edifícios de alto-padrão, pois apresentou um cenário em que foi registrado um recorde de demanda, de novo estoque entregue, além da taxa de vacância ter sido a mais baixa de todos os anos. A performance positiva desse produto pode ser verificada no gráfico a seguir, que compara o novo estoque entregue e o volume absorvido.

O mercado de edifícios "Triple $A$ " vem apresentando uma excelente valorização há cinco anos. Os valores de locação desta classe tiveram um crescimento médio de 15\% ao ano desde 1995.

O cenário é bastante favorável aos proprietários, pois os valores praticados estão proporcionando um melhor retorno de investimento. Até mesmo as regiões secundárias estão atingindo valores de locação altos, devido à falta de opções de prédios "Triple A" em regiões nobres da cidade. 


\section{NOVO ESTOQUE X ABSORÇĀO LIQUUIDA}

Triple A

\section{$\left(.000 \mathrm{~m}^{2}\right.$ úteis $)$}

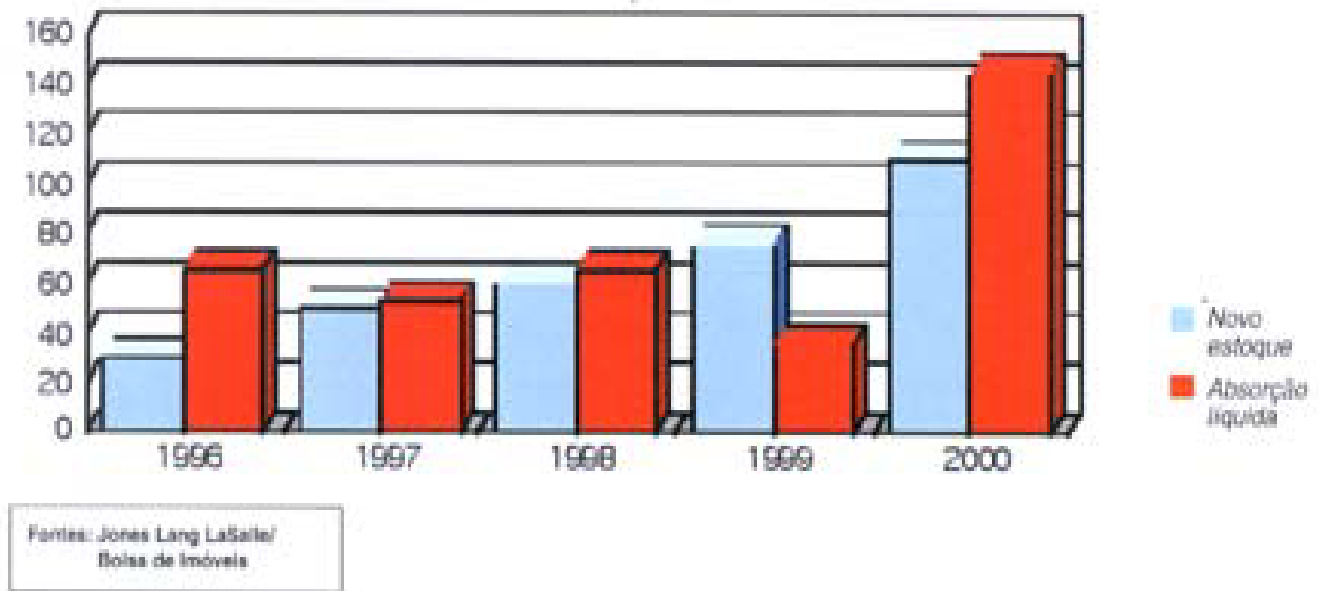

Gráfico 2- novo estoque entregue e o volume absorvido.

Fonte: http://www.torrenorte.com.br/mercado.htm

Por último, como o cenário atual para edifícios de alto padrão é de demanda aquecida e pouca oferta, em médio prazo, a expectativa é de que os valores continuem subindo, pois nos próximos 2 anos a oferta permanecerá baixa.

\section{Mercado de Escritórios: Perspectivas}

O ano de 2001 marcou o início de uma nova era, com perspectivas altamente otimistas para o mercado imobiliário, ao contrário do que ocorreu em 2000, ano cujos primeiros meses caracterizaram-se por um baixo volume de negócios.

Aquele clima de otimismo, que não ocorria no Brasil desde 1998, pôde ser comprovado pelos números do mercado imobiliário de São Paulo de 2000. Principalmente quando analisamos o segmento de edifícios de primeira linha (produto muito procurado por empresas de grande porte, tanto nacionais como estrangeiras), notou-se que os níveis de demanda estiveram muito mais altos do que os de oferta, tendência que permaneceu em 2001, já que a entrega de novo estoque deste padrão para o período representaram um volume aproximadamente 38\% inferior ao entregue em 2000.

Os níveis de preços pedidos por escritórios consolidaram uma tendência de que o valor de um imóvel esteja relacionado mais ao padrão do prédio do que à sua localização. A Paulista, que sempre foi a região com os valores mais altos da cidade, perdeu sua hegemonia para regiões menos centrais como a Berrini, por exemplo, onde está concentrada a maior parcela de volume de $\mathrm{m}^{2}$ úteis de alto padrão da cidade. 
Apresentamos a seguir como se comportou este segmento e a sua evolução durante o ano de 2000, até atingir o nível de "aquecimento" em que se encontra atualmente.

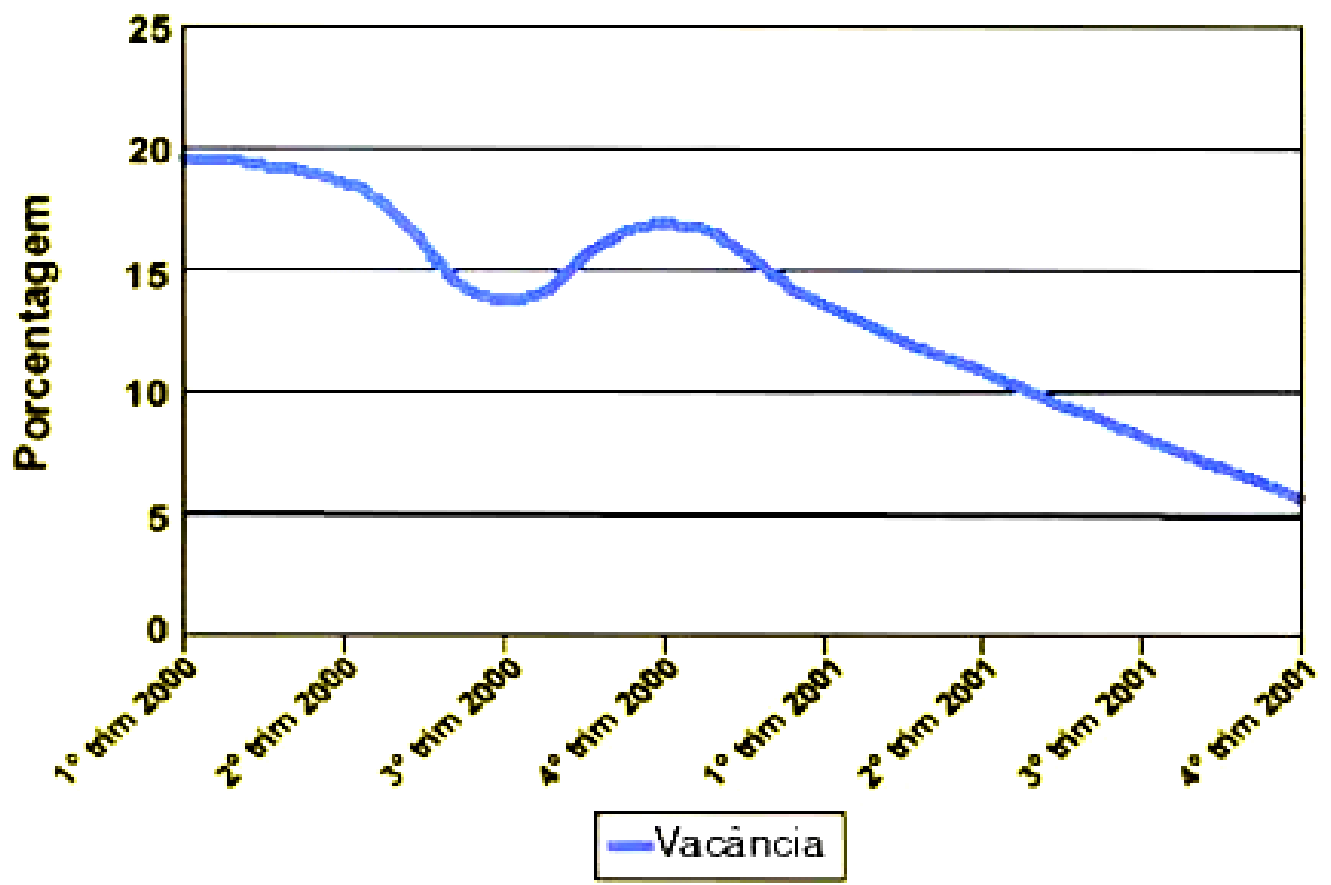

Fonte: Bolsa de Imó veis do Estado de São Paulo / Jones L ang LaSalle (*)

Gráfico 3- (*) A partir dos números levantados em pesquisa de campo pela Jones Lang LaSalle, foi feita análise do comportamento do mercado de escritórios de São Paulo e projetou-se as seguintes tendências.

Fonte: http://www.torrenorte.com.br/mercado.htm 
O presente trabalho destinou-se a fazer um estado da arte dos Edifícios Inteligentes, mostrando o que há de mais atual no assunto, estudando os casos mais recentes e significativos e enfatizando as tecnologias utilizadas, sejam os sistemas com os novos materiais, equipamentos, o hardware e software; sejam os serviços que tais sistemas permitem, ou ainda as ferramentas de gestão tecnológica dos sistemas.

Todos estes recursos estão colocados como ferramentas à disposição dessa nova forma de conceber os edifícios multifuncionais, que possuem espaços articulados para as atividades de escritório, habitação, entretenimento e lazer.

Durante a execução deste trabalho, vários fatores foram considerados relevantes ao estudo, entre eles: projeto, ocupação e pós-ocupação, concepção de espaços arquitetônicos onde serão inseridos o cabeamento, as máquinas, os equipamentos (tecnologia), a sala de controle, etc... Isto é, tudo o que tornará o Edifício Inteligente.

A análise de tais fatores durante a pesquisa, relatados nos capítulos anteriores, nos levam às seguintes conclusões:

\section{Sobre o Estado da Arte dos Edifícios Inteligentes - casos internacionais e nacionais}

Observou-se a tendência no mercado de uma ênfase no projeto de edifícios multifuncionais, articulando espaços para as atividades de negócios, habitação, entretenimento e lazer. Neste trabalho deu-se um enfoque especial aos edifícios de escritórios.

Organizou-se cronologicamente o aparecimento desses edifícios. Desde a época em que a relação com a palavra inteligente ficava somente ligada à Arquitetura (pois não se tinha a visão de controle conjunto dos sistemas integrantes de um edifício)e os recursos tecnológicos eram escassos ou com um custo absurdamente alto, e ainda, não havia nenhuma preocupação com a economia energética, com o conforto do usuário ou com a segurança, até os dias atuais, onde temos sistemas extremamente complexos e recursos da telemática.

Sobre o projeto de Arquitetura pode-se afirmar que houve uma mudança significativa na forma de conceber um edifício. A forma de pensar mudou devido a inúmeros fatores, entre eles o racionamento de energia.

A análise do desempenho do edifício está se tornando cada vez mais imprescindível em um projeto. Estudos sobre os confortos térmico, luminoso e acústico, não são mais considerados itens de encarecimento e retardamento de projetos e sim pontos chaves para a economia e para as estratégias de vendas.

Ainda sobre o projeto arquitetônico pode-se afirmar que a previsão de espaços tem sido muito discutida nos anteprojetos, onde são feitos levantamentos das necessidades atuais e futuras (espaços flexíveis) para 
possíveis modificações de layouts ou adequação das novas tecnologias da Telemática.

Sobre os postos de trabalho pode-se afirmar que o conforto dos usuários foi o item primordial para que houvesse essa verdadeira revolução nos escritórios. Não atenta-se somente aos aspectos de ergonomia, dos layouts e da utilização dos equipamentos de alta tecnologia, mas a todas as mudanças ocorridas dentro das empresas que aderiram a tais mudanças, colocando abaixo toda divisão de hierarquia dentro do ambiente de trabalho, literalmente!

Sobre o projeto Urbanístico pode-se relatar que a localização dos edifícios com alta tecnologia está intimamente ligada a regiões onde o suporte para estas tecnologias é garantido. Isso, foi se desenhando em São Paulo, do centro da cidade para a região da marginal Pinheiros, que no momento atende às necessidades destes edifícios. Vale salientar ainda que o projeto Paisagístico além de estar intimamente ligado ao projeto Urbanístico, hoje é considerado fator de bem estar entre os usuários e comercialmente um indicativo de preferência dos investidores.

\section{Sobre os Sistemas Tecnológicos utilizados e sobre os Serviços}

Entrando mais a fundo na organização do edifício, percebeu-se que os sistemas devem estar organizados de maneira a maximizar o seu desempenho. Isto pode ser obtido através de um projeto de "pré cablagem", que serve de suporte a todos os sistemas e possíveis upgrades.

Os sistemas e os serviços considerados foram: os de elétrico/iluminação, hidráulico, detecção e combate a incêndio, condicionamento ambiental, telecomunicações e rede, segurança, transporte vertical, conforto acústico e sonorização de ambientes. Para todos eles foram mostradas as possibilidades tecnológicas mais atuais e mais utilizadas, as necessidades de suporte e as funções de autogerenciamento.

Pode-se afirmar ainda que a necessidade de uma administração de complexidades é o ponto chave da automação predial, que envolve desde o conhecimento do processo até a influência da automação no desempenho global do edifício, passando pela padronização dos sistemas, constantes atualizações e estudo das tecnologias disponíveis para um melhor desempenho.

Ainda sobre a automação predial não se pode deixar de mencionar a gestão dos recursos tecnológicos. Aqui relacionam-se as três consideradas mais importantes, são elas;

- Gerenciamento dos sistemas e serviços. Preocupa-se com o monitoramento do estado dos equipamentos, o posicionamento das chaves de acionamento e execução da programação específica, dentre outras funções. 
- Gerenciamento de energia. Cuida da otimização dos recursos disponíveis e visa redução do consumo. Para isto realiza a manutenção dos programas de gestão de energia, a fiscalização dos processadores que possuem técnicas de auto-aprendizagem, a utilização de geradores em horários de pico, o desligamento da iluminação após o expediente, etc.

- A gestão da segurança dos sistemas. Tem como função básica gerenciar todos os sistemas integrantes do edifício, visando um perfeito funcionamento e em caso de falhas tomar providências para possíveis reparos.

\section{Sobre a gestão Empresarial do Edifício}

Foram abordados três aspectos neste item. O primeiro relata a Gestão da Produção que exigiu das construtoras grandes mudanças nos aspectos de pessoal, de gestão de recursos e outros. A construtora passou a ter um perfil de multifunções, atuando em áreas de incorporação, gestão de contratos e manutenção de empreendimentos, por exemplo. Para isso, estão sendo aperfeiçoados os departamentos executivos, administrativos e a gerência financeira. A necessidade de se diferenciar em um mercado altamente concorrido foi o principal motivo que impulsionou esta mudança.

Estas novas características da Gestão da Produção se estenderam aos próprios canteiros e operários, pois hoje podemos notar que até o próprio layout dos canteiros de obras passou por uma série de adaptações. Em algumas construtoras, é possível contar com um banco de dados da obra, no qual os operários fazem consultas. O treinamento para a utilização de novos materiais e novas tecnologias construtivas está sendo feito em locais especializados ou mesmo nos canteiros, visando com isso a familiarização dos operários e conseqüentemente uma melhor utilização do recurso disponível.

Sobre a Gestão Administrativa Predial pôde-se notar uma forte mudança. Antes tínhamos havia o zelador que era o responsável por todo o edifício, mas não possuía especialização nenhuma para tal cargo. Hoje temos profissionais formados e especializados em gestão predial, que agregam diversas funções, dentre as quais estão: previsão financeira, planejamento de manutenção, gestão de contratos, de reclamações, etc.

No setor de Investimentos em edifícios com alta tecnologia pôde-se notar nos últimos cinco anos um aumento bastante significativo de entrada de capital graças aos fundos de pensão que passaram a investir no setor. Hoje, investir em edifícios Inteligentes significa obter um rendimento mensal de acordo com a valorização das cotas e da participação nos rendimentos das locações.

\section{Convergência, Integração e Sintonia entre o Projeto de Arquitetura e os Sistemas de Alta Tecnologia Utilizados nos edifícios estudados. \\ O estudo de caso pôde mostrar que a integração das diversas áreas que fazem parte da criação de um edifício é fundamental. Arquitetos,}


engenheiros, construtores e responsáveis pela implantação dos sistemas, devem estar em perfeita sintonia para que os diversos projetos do edifício casem perfeitamente.

Analisando já a fase de conclusão da obra pôde-se notar que a manutenção preventiva feita também por uma equipe de técnicos em sintonia é o ponto chave para o perfeito funcionamento do edifício.

\section{Sobre a Metodologia da Pesquisa}

Descrição da metodologia da pesquisa:

Fez-se um levantamento profundo e completo das características desses edifícios, utilizando-se para isso a pesquisa de campo, com entrevistas, pesquisa bibliográfica, pesquisa na internet, dentre outros meios.

Cabe citar aqui que, como em qualquer trabalho de pesquisa, foram encontradas dificuldades para se estruturar o assunto. Dentre todas elas, considerou-se como principal, a obtenção de bibliografia específica sobre o tema, por se tratar de uma nova vertente da Arquitetura, com abordagem pioneira.

Acertos e dificuldades da metodologia:

A forma de contato utilizada com as construtoras foi uma carta de apresentação, que talvez não tenha sido a maneira ideal. Existe atualmente nas construtoras e administradoras uma grande preocupação com a segurança em geral, agravada com os acontecimentos que marcaram o mundo no dia 11 de setembro de 2001. Todavia, algumas ainda abriram suas portas e contribuíram significativamente com o presente trabalho.

O contato positivo com os administradores prediais pôde dar uma visão completa e profunda do que realmente é administrar um edifício que possui um enorme contingente de pessoas que circulam diariamente. 0 conhecimento das novas tecnologias visto de perto é algo realmente indescritível. Só aqueles que convivem neste meio são capazes de imaginar até onde uma "máquina" pode ir.

\section{Continuidade da Pesquisa}

O assunto em questão é muito complexo e nos permite uma vasta gama de abordagens diferentes.

Como sugestão para pesquisas futuras, pode-se citar o estudo das fachadas inteligentes, que estão sendo usadas nos Edifícios de alta tecnologia, por ser um assunto interessante, atual e de grande viabilidade econômica, e que atualmente vem tendo grande procura no mercado de trabalho por empresas da área de alta tecnologia. Outra sugestão seria a administração dos edifícios inteligentes, um novo caminho que abrange uma área multidisciplinar e que cada vez mais está sendo empregada no Brasil. 


\section{Referências Bibliográficas - Livros, Artigos, Monografias, Teses, Ełc.}

AIDAR, F.H. O incômodo barulho das instalações hidráulicas. Revista Téchne, 35, 38-42, 1998. São Paulo. Ed. PINI.

ALUCCl, M.P. Fachadas transparentes: do conforto ao consumo de energia. Revista Téchne, 40, 53-55, 1999. São Paulo. Ed. PINI.

ALVES, lana Alexandra Rodrigues. Informática na integração projetoprodução: processos construtivos flexíveis. Dissertação de mestrado. EESCUSP.1996

ANDRADE, C.M. \& SOUZA, M.A. O desempenho da ocupação. Revista Téchne, 27, 35-37, 1997. São Paulo. Ed. PINI.

ANGEL, P. \& FRAIGI, L. O futuro dentro de casa. Revista Téchne, 11, 12-14, 1994. São Paulo. Ed. PINI.

ANGEL, Patrícia Marta. Introduccion a la domotica. Notas. Buenos Aires: Ebai, 1993.

ANTA BORGES, Manuel. Curso sobre Edifícios Inteligentes. Serviço de Publicações do Colégio Oficial dos Arquitetos de Madri, Madri, 1989.

ARONOVIT, RICARDO. Entrevista com a autora.

Associação Brasileira de Normas Técnicas, NBR5410 - Instalações Elétricas de Baixa Potência.

Associação Brasileira de Normas Técnicas, NBR9441/1993 - Projeto de Norma do Sistema de Detecção e Alarme de Incêndio.

BATAGLIA, E.D.G. \& AKUTSU,M. Controle do desempenho térmico no projeto do edifício. Revista Téchne, 52, 50-54, 2001. São Paulo. Ed. PINI.

BAUER, C. J. Energy Management Systems: Trends and avances. In MC Clelland, S. Intelligent Buildings. pp 64-73. Ifs Publications. London, 1988.

BAYEUX, P. Forros: Caminho da especificação. Revista Téchne, 46, 56-59, 2000. São Paulo. Ed. PINI.

BÉRTOLO, T. Sistemas em convergência. Revista Téchne, 49, 44-47, 2000. São Paulo. Ed. PINI.

BORGES, L. \& FRANÇA, E.C. O ar tem seu valor. Revista Téchne, 23, 38-40, 1996. São Paulo. Ed. PINI.

BRATKE, C. Uma obra sem maquiagem. Revista Téchne, 24, 12-14, 2000. São Paulo. Ed. PINI. 
BRENDA L. (org) - The art of human-computer interface design, Ed AddisonWesley, Ma, 1991.

CAMARGO A.R., "Cidade e Informática, Contatos e Interações: Explorando manifestações da Urbanização Virtual- Relatório Parcial CNPq- Julho 96, EESC-USP, São Carlos, 96

CAMARGO, A.R e Sousa M. S de L,:"Introducing Cooperative Design in Brazil: A scenario and Agenda for rechearch", no. "Computers in Context: Joining Forces in Design - Third Decennial Conference", de 14-18/08/95, em Aahus, Dinamarca, EESC -USP, São Carlos, 95

CAMARGO, A.R." A Urbanização Virtual e os Bens e Serviços Públicos assistidos pelas novas tecnologias originárias da Informática e das Telecomunicações", no Encontro da ANPUR, de 22 a 26 de maio 1995, realizado em Brasília. EESC -USP, São Carlos, 95

CAMARGO, Azael Rangel. Caderno de Pesquisa. Trabalho de Pesquisa. CNPq, 1994-95.

CAMARGO, Azael Rangel. Políticas públicas relativas aos Bens e Serviços Urbanos originados da Telemática: Pensando as formas de Intervenção Planejamento e Desenho, e os Meios de Ação - Design de Ambientes Cognitivos e Comunicativos Trabalho de Pesquisa. CNPq, 1997-99.

CAMPOS, Alberto. "As edificações de terceiro milênio". Revista Construção / $\mathrm{ABCl}$ - Encarte Técnico Edifícios Inteligentes, São Paulo, 2355, págs. 25 e 26, 1993.

CAPOZZI, S. A conta do ar puro. Revista Téchne, 35, 50-53, 1998. São Paulo. Ed. PINI.

CASTRO NETO, Jayme Spinola. "A Segurança nos Edifícios Inteligentes". Boletim Informe, São Paulo, 22, págs. 3 e 4, 1991.

CASTRO NETO, Jayme Spinola. Edifícios de alta tecnologia. São Paulo, 1994.

COZZA, E. Estrutura: Mudança de eixo. Revista Téchne. 38, 24-27,1999, São Paulo. Ed. PINI.

COZZA, E. Racionalização: Quando tudo se encaixa. Revista Téchne. 37, 2832,1998, São Paulo. Ed. PINI.

CRESPO, R. Para que cliente bravo?. Revista Info Exame, Novembro/1998, 116-117.

CRESPO, R. Quando o vento é a sua rede. Revista Info Exame, Novembro/1998, $118-120$.

CRESPO, R. Redes - Soluções para Netware: Enfim pegou !. Revista Info Exame, Abril/1999, 110-111. 
CRESPO, R. Redes - Soluções para Netware: Sabe da última?. Revista Info Exame, Março/1999, 112-113.

CSTB, Dossie Immotique. n.75, junho, 1994.

DEL CARLO, Ualfrido; Edifícios Inteligentes (EI) e controle das condições ambientais. Encontro de Professores de Conforto Ambiental, 2. Anais. p.21-22. João Pessoa : UFPB, 1994

DIANA, T B; Arquitetura no processo de globalização. Novos programas para centros empresariais : os Edifícios Inteligentes. Simpósio de Iniciação Cientifica da Universidade de São Paulo USP, p.224 res.2.5., 1995.

DIAS, J.P. O outro lado da terceirização. Revista Construção. 2736, 38, 2000, São Paulo. Ed. PINI.

EDUARDO GYURKOVITZ. Entrevista com a autora.

EMBRATEL, "Brasil abre infovias para o futuro". O Estado de São Paulo, 27 de março de 1994. Encarte Especial. Págs. 7 e 13.

Fabricio, M.M. - Processos Construtivos Flexíveis, EESC USP, S. Carlos 1996. (Dissertação de Mestrado)

FACCIONI FILHO, M. \& CLAUSEN, W. Cabeação estruturada e infra-estrutura em Edifícios Inteligentes. In: Congresso Brasileiro de automação e prédios inteligentes. São Paulo, 2000.

FERREIRA, M V, Ambiente compatível (depoimento a Maria Inês Camargo) Construção São Paulo, n.2373, p.16-7, 02 ago. 1993.

FISCHER, N. Industrialização máxima. Revista Téchne, 53, 66-72, 2001. São Paulo. Ed. PINI.

FISCHER, N. Rumo ao mercado de capitais. Revista Téchne, 53, 38-42, 2001. São Paulo. Ed. PINI.

FONSECA, Tatiana. "Um edifício ao alcance dos dedos". Revista Exame Informática, São Paulo, 11, págs. 34 a 37, 1991.

FRANÇA, Eudes Cristino \& BORGES, Luciano. A espinha dorsal dos Edifícios Inteligentes. Revista Téchne. 32. 44-47.1998. São Paulo. Ed. PINI.

FRAZATO, C.W.P Edifícios Inteligentes: Conceitos e avaliação, 2000. Http://www.abrapinet.org.br/files/cf-bicsi.pdf

GALDINO, L. Elevadores, uma visão dos sistemas de controle. Revista Téchne, 30, 38-40, 1997. São Paulo. Ed. PINI.

GONÇALVES, Orestes M. Avanços conceituais e tecnológicos. Revista Téchne. 12. 30-34.1994. São Paulo. Ed. PINI. 
GRAÇA, M E A, Edifícios Inteligentes. Encontro de Informática na Engenharia Civil, 1. Anais. p.145-56 São Paulo : Epusp, 1986.

GREGO,M. Redes - Soluções para Netware: Hora de ATM?. Revista Info Exame, Maio/1998, 102.

GREGO,M. Redes - Soluções para Netware: Uma banda para todos. Revista Info Exame, Outubro/1998, 132.

GREGO,M. Tecnologia: O futuro já começou. Revista Info Exame, Janeiro/1999, 48-51.

HAYES-ROTH, Frederick et al. Building expert systems. teknowledge series in knowledge engineering ; 1 XVI, 444 p. : ill. ; 1983.

INSTITUTO de pesquisas tecnológicas. Tecnologia de edificações. Divisão de Engenharia Civil. São Paulo, 1988.

INTELLIGENT Buildings Institute. Intelligent Buildings Definition - guideline. Intelligent Buildings Institute Foundation, 1a edição, 1987, Washington, USA.

ISHIKAWA, E. Automação predial.: Epusp, Dep de Engenharia de Energia e Automação Elétricas, p. 133-137. 1994. São Paulo.

JUGEND, D. Automação high-tech. Revista Téchne, 48, 20-25, 2000. São Paulo. Ed. PINI.

JUVÊNCIO, F C, Impacto da informatização no escritório de Arquitetura. Simpósio de Iniciação Cientifica da Universidade de São Paulo USP, p.230 res.2.17. São Paulo, 1995.

KIRSCHNING, Ingrid. Edifícios Inteligentes. Licenciatura em engenharia de Sistemas Computacionais. Universidad de las Américas Puebla, México. Junho, 1992.

KISS, P. Acústica: Muito barulho por tudo. Revista Téchne, 43, 30-31, 1999. São Paulo. Ed. PINI.

KISS, P. Concerto a 120 mãos. Revista Téchne, 39, 18-24, 1999. São Paulo. Ed. PINI.

KISS, P. Edificações: Mirante da evolução. Revista Téchne, 40, 22-28, 1999. São Paulo. Ed. PINI.

KISS, P. Edificações: Recepção a novos hóspedes. Revista Téchne, 38, 20-23, 1999. São Paulo. Ed. PINI.

KISS, P. Energia solar: A fonte da eternidade. Revista Téchne, 41, 34-37, 1999. São Paulo. Ed. PINI.

KISS, P. Fachadas: pulmões prediais. Revista Téchne, 39, 36-38, 1999. São Paulo. Ed. PINI. 
KISS, P. Fechamentos transparentes: a luz dá o tom. Revista Téchne, 40, 46-50, 1999. São Paulo. Ed. PINI.

KISS, P. Iluminação: Luz plena. Revista Téchne, 43, 26-28, 1999. São Paulo. Ed. PINI.

LAMBERTS, R et al. Eficiência energética na Arquitetura. São Paulo, 1997.

LANDERO, Maria Antonia. "Con decir abracadabra - La información aplicada al desarrollo de los Edificios Inteligentes". Revista MOPU, vol. 362. Madrid, 1989.

LEAL, U. Acústica: A matemática do som das salas especiais. Revista Téchne, 53, 48-55, 2001. São Paulo. Ed. PINI.

LEAL, U. Conforto térmico : Pé quente, cabeça fria. Revista Téchne, 43, 42-43, 2000. São Paulo. Ed. PINI.

LEAL, U. Obra: Construção documental. Revista Téchne, 48, 57-60, 2000. São Paulo. Ed. PINI.

LEAL, U. Retrofit: Reforma necessária. Revista Téchne, 46, 44-49, 2000. São Paulo. Ed. PINI.

MAGALHÃES, A. Esquadrias: Caixilho pintado ou anodizado? Revista Téchne, 35, 43-45, 1998. São Paulo. Ed. PINI.

MALUF, A J. Fieldbus e alternativas tecnológicas em automação predial e residencial. :, Isa Show Brasil/95. Anais. : Isa South American Region, 1995. p.1367-1375, 1995. São Paulo

MALUF, A J. Integração de redes comerciais e barramentos de campo nos Edifícios Inteligentes. Eletricidade Moderna, v.23, n.251, p.84-95, fev. 1995.

MANGANO, L.V., Los Edifícios Inteligentes. OBRAS, p.38-45, Abril, 1997.

MARTE, Cláudio Luiz. Automação Predial. São Paulo, 1995.

MARTE, Cláudio Luiz. Estudo e análise das unidades funcionais remotas no controle distribuído em processos de automação predial. Dissertação de Mestrado. Escola Politécnica da USP. São Paulo, 1994.

MARTINS, J E P, Aplicações de controladores embutidos (embedded controllers) em instrumentação inteligente e domótica. Simpósio Interno da pós-graduação do Dfcm. Resumos. Ifqsc-Usp, p.66., 1994. São Carlos.

MARTUCCI, R. Projeto Tecnologico para Edificações: Utopia ou Desafio? FAUUSP, SP, 90. (tese de doutorado)

MASCARÓ, J. A luz do projeto. Revista Téchne, 12, 12-14, 1994. São Paulo. Ed. PINI.

MAWAKDIYE, A. Edifícios inadequados. Revista Téchne, 33, 48-50, 1998. São Paulo. Ed. PINI. 
MENCONI, D. Estudo de caso. Hotel Renaissance: Um hotel para cada hóspede. Revista Info Exame. Julho/1998, 128-129.

MENCONI, D. PCs iguais. Revista Info Exame, Fevereiro/1999, 96-97.

MILITELLO, K. Reunião virtual com o chefe. Revista Info Exame, Setembro/1998, 108-109.

MITIDIERI FILHO, C.V. Paredes de chapas de gesso acartonadas. Revista Téchne, 30, São Paulo. Ed. PINI.

MIYAGI, P. E, Domótica : controle e automação. Notas Apresentado a Escuela Brasileno-Argentina de Informatica, 6, p. 108. Embalse : Ebai, 1993.

MOREIRA, M.I. Cadê o fio que passava aqui?. Revista Info Exame, Maio/1999, 118-119.

MOURA, E. Brasil: Outros tempos, outras Arquiteturas. Revista Arquitetura \& URBANISMO, 73, 1997, 68-74.

NACAMOTO, N. H. - Critério de Projeto do Sistema de Supervisão e Controle Predial E2. São Paulo, 1989. (Relatório Interno Itaú Planejamento e Engenharia Ltda, n. FE03-00IS1-200-ver.01).

NEPOMUCENO, J.A. Piso flutuante para controle de ruído. Revista Téchne, 53, 124-126, 2001. São Paulo. Ed. PINI.

NOBRE, A. L. World Trade Center, SP: Uma vitrine internacional. Revista Arquitetura \& Construção, 60, 1995, 41-49.

NOBRE, A.L. Edifício Plaza Centenário, São Paulo: Nova presença na marginal. Revista Arquitetura \& Construção, 61, 1995, 39-44.

NUNES, R. J. C.: "Integração de Serviços para Edifícios Inteligentes", Tese de Doutoramento em Engenharia Electrotécnica e de Computadores, Instituto Superior Técnico, Julho 1995.

PRADO, R T A. Automação predial :benefícios e riscos. Revista Politécnica, v.90, n.210, p.46-48, jul./set. 1993. São Paulo.

PRADO, R T A. Conservação de energia aos Edifícios Inteligentes. Construção, São Paulo, v.45, n.2328, p.15, set. 1992.

PRADO, R T A. Energia, readequação tecnológica de edifícios e automação predial. Encontro Nacional de Instalações Elétricas, 5. V Enie: Anais. p. 5-5.11. 1996. São Paulo.

RABELLO, S. Forros: Qualidade na cabeça. Revista Téchne, 28, 30-33, 1997. São Paulo. Ed. PINI.

RABELLO, S. Projeto: Como ser o primeiro da classe. Revista Téchne, 29, 32-35, 1997. São Paulo. Ed. PINI. 
RAMOS, T.O. O call center cai na internet. Revista Info Exame, Outubro/1998, 122-123.

RATTNER, H; Fascínio do país automatizado. Revista Nacional de Telemática, v.8, n.89, p.41-45, set. 1986. 1986. São Paulo.

Revista Veja. A casa inteligente. 07/04/1999. 132.

RIBEIRO BRASILIANO, Antônio Celso "A Integração da Segurança com a Engenharia e a Arquitetura". Boletim Informe, São Paulo, 29, págs. 14 a 16 , 1992.

ROCHA, S. Esquadrias: Janelas enquadradas. Revista Téchne, 31, 16-20, 1997. São Paulo. Ed. PINI.

ROCHA, S. lluminação: Luz em tempo real. Revista Téchne, 16, 35-40, 1995. São Paulo. Ed. PINI.

RODRIGUES, M. Construção virtual. Revista Téchne, 51, 30-35, 2001. São Paulo. Ed. PINI.

RODRIGUES, M. Telecomunicações: Edifícios plugados. Revista Construção, 2736, 36-37, 2000. São Paulo. Ed. PINI.

ROMANO, E; Tecnologia encolhe área de escritórios. [Depoimento a Telma Figueiredo]. Folha de São Paulo. Imóveis, p.1-1, 24 jul. 1994.

ROMERO, Marcelo de Andrade. "Ambiente Inteligente". Depoimento a Rodrigo Cavalcante.- Ser Humano. São Paulo, SP, maio de 1988, v. 32, n. 132, p. 30-33.

ROMERO, Marcelo de Andrade. Arquitetura, comportamento e energia: análise do desempenho energético e do nível de satisfação dos usuários em edifícios de escritório na cidade de São Paulo, utilizando-se procedimentos de avaliação pós-ocupação. Grau Tese (Livre Docência) Faculdade de Arquitetura e Urbanismo da Universidade de São Paulo, s.n., 1997.

ROSSO, S. Toda a luz de sol a sol. Revista Téchne, 15, 39-43, 1995. São Paulo. Ed. PINI.

RT-IPT N ${ }^{\circ}$ 12. Paredes em chapas de gesso acartonado Knauf. Revista Téchne, 50, 72-75, 2001. São Paulo. Ed. PINI.

RT-IPT No 8. Sistema Placostil de paredes de chapas de gesso acartonadas. Revista Téchne, 34, 63-64, 1998. São Paulo. Ed. PINI.

RUBIN, MARC. Entrevista com a autora.

RYAN, Jonh L. "The EUREKA home system project". Domotique 88. Premier Conference sur l'Habitat Inteligent. Paris, França, 14 e 15 de janeiro de 1988, págs. 4-7. 
SABBAG, H.Y. Renaissance Hotel. Revista Arquitetura \& Construção, 72, 1997, 50-57.

SAC - SISTEMAS AVAZADOS DE CONTROL S.A. Sistema TREND para el control inteligente de edificios. Madri, 1988.

SANTIN, E. Lar, autolar. Revista Téchne, 9, 14-17, 1994. São Paulo. Ed. PINI.

SAYEGH S. Força domada: quilowatts de economia. Revista Téchne, 53, 5665, 2001. São Paulo. Ed. PINI.

SAYEGH, S. Empreendimento: Controle total. Revista Construção, 2736, 34-35, 2000. São Paulo. Ed. PINI.

SERRA, G.G. Arquitetura, Urbanismo e multimídia. Revista Téchne, 11, 18-20, 1994. São Paulo. Ed. PINI.

SILVEIRA, J.G. Automação Predial e Projeto do Controle de Sistemas. PUC-RS

SIQUEIRA, E M. Mundo na era das redes inteligentes. Revista Nacional de Telemática, n.155, p.20-6, 1992. São Paulo.

SIQUEIRA, E M. Telemática exige cabos de alta qualidade. Revista Nacional de Telemática, n.115, p.18-20, 1989. São Paulo.

SOUSA, M. As torres prateadas do oriente. Revista Téchne, 30, 50-53, 1997. São Paulo. Ed. PINI.

SOUSA, M. Energia: Não jogue fora, conserve. Revista Téchne, 12, 15-20, 1994. São Paulo. Ed. PINI.

SOUSA, M. Gesso: O argumento da leveza. Revista Téchne, 19, 24-27, 1995. São Paulo. Ed. PINI.

SOUSA, M. Inteligente é você. Revista Téchne, 18, 38-41, 1995. São Paulo. Ed. PINI.

SOUZA, M. Acústica: Derrubando decibéis. Revista Téchne, 20, 14-17, 1996. São Paulo. Ed. PINI.

SOUZA, M. Alguns degraus acima. Revista Téchne, 8, 30-32, 1994. São Paulo. Ed. PINI.

SPECHT, Marina. "Por favor llamane de tu ; El Maketing de Base de dados, un nuevo sistema para vender". EL PAIS, Madri,27 de novembro de 1988, Espacio Negocios, pág. 20.

SPOSITO, João Ismael. "Apoio à Manutenção, Controle de Energia e Prevenção de Incêndio". Revista Eletricidade Moderna, São Paulo, 220, págs. 32 a $35,1992$.

TELEFÔNICA SISTEMAS S.A. Cableado Integral de Edificios. Madri, 1989. 
TELEFÔNICA SISTEMAS S.A. Descripción General del Sistema IBERCOM. Madri, 1989.

TELEFÔNICA SISTEMAS S.A. Sistemas de Videoconferência. Madri, 1989.

TRONCONI, Oliviero; L'edificio intelligente: l'innovazione informatica, telematica e dei sistemi di automazione per il settore delle costruzioni., p. 438. 1990. Milão

VASCO CALDEIRA. Idéias de Arquitetura (escritórios). 2000. http://www.luxalon.com.br

VIDAL, Rafael. "Difícil cambio - El mercado continuo encuentra problemas para superar las tradiciones". EL PAIS, Madri, 28 de maio de 1989, Espacio Negocios, pág. 24.

WOLF, J. Centro Empresarial: Definindo um eixo. Revista Arquitetura \& Construção, 37, 1991, 38-45.

\section{Referências Bibliográficas - Sites da Internet}

http://abilux.com.br

http://arcoweb.com.br/arquitetura/arquitetura54a.asp

http://eventos.matrix.com.br/edicao 12/premiados08.html

http://images.google.com/

http://penta.ufrgs.br/rc952/trab2/atm.html

http://penta.ufrgs.br/tp951/rdsi/tele_pri.html

http://www.aflaloegasperini.com.br/

http://www.arquitetura.com.br/bratke/

http://www.asbea.org.br/jornal/j63/artigo2_63.htm

http://www.birmann.com.br/edif/b21/eng21.htm

http://www.bolsaimoveis.com.br/

http://www.bolsaimoveis.com.br/cenu_convencoes/

http://www.creare.com.br

http://www.cs.clark.edu/ hum101/Humanities_101/ architecture.htm

http://www.eibg.net/

http://www.escritoriosmusa.com.br/ 
http://www.feixe.com.br/clientes.htm

http://www.google.com

http://www.google.com/search? q=intelligent+building\&btnG=Pesquisa+Goo gle\&hl=pt\&lr=

http://www.greatbuildings.com/architects.html

http://www.imovelweb.com.br/iw_editorial.asp?

http://www.intelbuildsys.com/

http://www.luxalon.com.br/

http://www.moro.com.br/

http://www.nesic.co.jp/cyber_e/descr_2.html

http://www.nordx.com/public/htmen/3_1.htm

http://www.planetaimovel.com/conteudo/casahightech/destaques/160301/ tecnologia.asp

http://www.pritzkerprize.com/pjohn.htm

http://www.qualyconstrutora.com.br/inf2.html

http://www.ruyohtake.com.br/ 